\title{
WestVirginiaUniversity
}

THE RESEARCH REPOSITORY @ WVU

Graduate Theses, Dissertations, and Problem Reports

2017

\section{War on the Mind: Trauma and Coping among Union Soldiers and Veterans}

Kathleen Anneliese Logothetis Thompson

Follow this and additional works at: https://researchrepository.wvu.edu/etd

\section{Recommended Citation}

Thompson, Kathleen Anneliese Logothetis, "War on the Mind: Trauma and Coping among Union Soldiers and Veterans" (2017). Graduate Theses, Dissertations, and Problem Reports. 7136.

https://researchrepository.wvu.edu/etd/7136

This Dissertation is protected by copyright and/or related rights. It has been brought to you by the The Research Repository @ WVU with permission from the rights-holder(s). You are free to use this Dissertation in any way that is permitted by the copyright and related rights legislation that applies to your use. For other uses you must obtain permission from the rights-holder(s) directly, unless additional rights are indicated by a Creative Commons license in the record and/ or on the work itself. This Dissertation has been accepted for inclusion in WVU Graduate Theses, Dissertations, and Problem Reports collection by an authorized administrator of The Research Repository @ WVU.

For more information, please contact researchrepository@mail.wvu.edu. 


\title{
War on the Mind: \\ Trauma and Coping among Union Soldiers and Veterans
}

Kathleen Anneliese Logothetis Thompson

\author{
Dissertation submitted to the \\ Eberly College of Arts and Sciences \\ at West Virginia University \\ in partial fulfillment of the requirements for the degree of \\ Doctor of Philosophy \\ in \\ History
}

\author{
Jason Phillips, Ph.D., Chair \\ Aaron Sheehan-Dean, Ph.D. \\ Brian Luskey, Ph.D. \\ Katherine Aaslestad, Ph.D. \\ Jeffrey Daniels, Ph.D. \\ Department of History
}

Morgantown, West Virginia

2017

Keywords: Civil War; Mental Trauma; Civil War Medicine; Union Army; Union Veterans

Copyright 2017 Kathleen Anneliese Logothetis Thompson 


\section{ABSTRACT \\ War on the Mind: Trauma and Coping among Union Soldiers and Veterans}

\section{Kathleen Anneliese Logothetis Thompson}

"War on the Mind: Trauma and Coping in the Union Army," is a work of social, cultural, and military history and examines experiences of mental trauma in the Union Army during the war and among veterans in the post-war period. Without our modern definition of Post-Traumatic Stress Disorder, Civil War soldiers had a very different view of how they were mentally experiencing the war. By looking at soldier accounts and the records of insane asylums it is clear that soldiers did have experiences of trauma and insanity during or related to their wartime service. However, those same asylum records, as well as medical and military policies and pension records, reveal that nineteenth-century Americans-doctors, military personnel, and the soldiers themselves - interpreted insanity as produced by physical or moral causes, not by the horrible experiences of warfare. My research analyzes official forms of treatment and diagnosis in the military and medical fields during the war as well as strategies of coping developed by the soldiers themselves. In the post-war period, the medical and social perceptions of insanity did not change drastically. Instead, society and the government distributed aid and support based on the same foundation of physical and moral causation as during the war. As a result of these continued perceptions of insanity, veterans' organizations and commemorations served as a coping mechanism in addition to the political and social purposes already studied by historians. At the same time that veterans' organizations, such as the Grand Army of the Republic, acted to commemorate their participation in the war and push for veterans' benefits in the post-war period, these groups also provided veterans support systems that helped those struggling to survive and those struggling with their wartime experiences. By looking at both the wartime and post-war periods, this research demonstrates that the Civil War, which sparked great transformations in many areas, did not significantly change the study and care of the insane. Instead, the prevailing culture of nineteenth-century America-including notions of masculinity, standards of social behavior, and beliefs about society's relationship with the governmenthindered the acceptance of the idea that the horrific experience of war might itself affect soldiers. 


\section{Table of Contents}

Introduction: “All very much worn out": Trauma and the Civil War..............1

A Note on Research.........................................................21

Chapter One: "The Strain on Our Minds and Bodies had been Severe":

The Traumatic Experience of Civil War Soldiering......................24

Chapter 2: "The Supposed Exciting Cause is the War...The Disease is Probably Hereditary":

Official Definitions and Treatments of Insanity and Mental Illness.........62

Chapter Three: "I take great pains to take care of myself":

The "Unofficial" Coping Strategies of Union Soldiers....................101

Chapter 4: "Disqualified from Procuring Their Own Maintenance...

by reasons of wounds... or sickness": Government and Medical

Treatment of Insane Soldiers in the Post-War Period......................153

Chapter Five: "To Sustain with Him the Relation of Comradeship":

Veteran Coping and Societal Pressures......................................................191

Conclusion: Trauma from the Civil War to the Twenty-First Century..............215

Bibliography........................................................ 229 


\section{Introduction:}

\section{"All very much worn out":}

\section{Trauma and the Civil War}

On May 9, 1864, Private Lorenzo G. Babcock of Co. E, $125^{\text {th }}$ New York Infantry shot himself in the breast near Todd's Tavern, Virginia. Babcock's unit had just fought in the Battle of the Wilderness with thirty-six percent casualties, only to keep pushing south as part of General Ulysses S. Grant's Overland Campaign. By the $9^{\text {th }}$, comrades testified, the unit was exhausted, overcome by the heat, and "all very much worn out." In the midst of this, comrades noted Babcock becoming excited and nervous, exclaiming that the enemy was approaching when all was quiet at camp, and attempting to shoot a fellow soldier he called a "Reb." Comrade H. Sykes testified that Babcock's friends tried to calm him down, but having their own duties to attend to in the midst of the campaign he was largely left alone and in the fighting on May $9^{\text {th }}$, Babcock killed himself. ${ }^{1}$

Less dramatic, but more common, is the case of Michael Schwenk of the $56^{\text {th }}$ New York Infantry, who spent much of his post-war life in insane asylums in Connecticut, Minnesota, California, and Massachusetts. In 1864, Schwenk suffered a "sunstroke" while serving in the army which caused him to become deranged. Sent initially to a regular hospital, Schwenk was transferred to the Government Hospital for the Insane in Washington, D.C. where he was discharged from the service. His departure from the army did nothing to cure his ailments and he was a patient at insane asylums until at least 1890 as recorded in his pension file. ${ }^{2}$

\footnotetext{
${ }^{1}$ Mother's pension application (Mary; soldier Lorenzo Babcock) 197327, certificate 283941. National Archives, Washington, D. C.

${ }^{2}$ Michael Schwenk pension application 414083, certificate 668845. National Archives, Washington, D.C.
} 
Both of these cases illustrate the mental toll of warfare on Civil War soldiers, whether an immediate case of suicide or a long-term case of insanity resulting from service. In today's postVietnam world, the idea of Post-Traumatic Stress Disorder (PTSD) or soldiers traumatized by wartime experiences is common and the current military works to research and treat the symptoms of trauma to ensure the mental health of their soldiers. PTSD, first officially included as a diagnosis in 1980, requires an individual to experience an event that is life-threatening or otherwise threatens physical harm, includes responses of fear, helplessness, and horror, and creates lasting and recurrent symptoms connected to this traumatic event. Symptoms of PTSD include nightmares, flashbacks, irritation and nervousness, emotional numbness or distancing one's self from surroundings, difficulty concentrating, hyperarousal, depression or anger, feeling a loss of control, guilt and shame, and difficulty sleeping. Today PTSD is defined as an anxiety disorder that psychologists Mooli Lahad and Miki Doron claim affects about eighty percent of the Western World and causes long-term symptoms in forty percent of cases. ${ }^{3}$

The debate among historians and psychologists is whether military conflicts through the course of human history share the same trend of mental breakdown — allowing historians to carry the modern diagnosis of PTSD backwards in time to analyze previous conflicts - or whether each major war creates its own form of mental collapse. Historians, for the most part, agree that using the diagnosis of Post-Traumatic Stress Disorder in conflicts earlier than Vietnam and the 1980 official diagnosis is ahistorical; however, this should be only a question of terminology because the signs and symptoms of traumatic experiences in warfare are evident in earlier

\footnotetext{
${ }^{3}$ Mooli Lahad and Miki Doron, Protocol for Treatment of Post Traumatic Stress Disorder. SEE FAR CBT Model: Beyond Cognitive Behavior Therapy \{Part of the NATO Science for Peace and Security Project ASI 983481\} (Amsterdam: IOS Press, 2010), vii, 17-21; John P. Wilson and Beverly Raphael, International Handbook of Traumatic Stress Syndromes (New York: Plenum Press, 1993), 2; Stanley Krippner, Post-Traumatic Stress Disorder (Santa Barbara, CA: Greenwood, 2012), 7.
} 
conflicts. Psychologists largely argue that—whatever it was named at the time-mental breakdown itself has been evident in conflicts of the twentieth and twenty-first centuries, and even earlier. According to psychologists, the human brain has responded physically to trauma and stress the same way through time. This suggests that some type of mental trauma has affected soldiers in all of humanity's conflicts. Mental collapse has been recognized for centuries, with recorded cases at least back to the Thirty Years War. What has changed over time is the manifestations and symptoms of the disorder, the diagnosis and scientific understanding of the ailment, and society's response to those suffering it. Consequently, while the term PTSD would be incorrect to use in a study of the Civil War, it does not negate the presence of trauma and its effects on soldiers. ${ }^{4}$

Our modern familiarity with trauma and PTSD means that evidence of trauma in the Civil War seems only natural considering the brutal nature of the war. Indeed, some of the symptoms attached to PTSD can be found in Civil War soldiers and cases such as Babcock's and Schwenk's make it clear that trauma affected soldiers mentally and physically. However, we cannot label cases in the nineteenth century with the diagnosis of Post-Traumatic Stress Disorder. Instead of labeling nineteenth-century actors with the diagnosis of PTSD, I refer to mental trauma and soldiers being traumatized. The word "trauma" originated in the late seventeenth century from a Greek word meaning "wound." Nineteenth-century Americans recognized the word "traumatic," particularly in regards to physical wounds, so the word itself is not the issue. Using "trauma" to refer to modern conditions such as PTSD would be a mark of anachronism, implying that these conditions were recognized at that time. Here is where I

\footnotetext{
${ }^{4}$ J. M. Binneveld, From Shell Shock to Combat Stress: A Comparative History of Military Psychiatry (Amsterdam: Amsterdam University Press, 1997), 3-4; Edgar Jones, Shell Shock to PTSD: Military Psychiatry from 1900 to the Gulf War (Hove: Psychology Press, 2005), xvi-xvii.

${ }^{5}$ Stanley Krippner, Post-Traumatic Stress Disorder, 2.
} 
distinguish "trauma" from "Trauma." "Trauma" as a proper noun refers to the currently recognized conditions of Post-Traumatic Stress Disorder and Traumatic Brain Injury. On the other hand, "trauma" is a generic term that implies an experience may have been traumatic or refers to a soldier's reaction to an event. Thus, when using the term "trauma" through this work, I do not imply the existence of PTSD but am referring to traumatic experiences and reactions. In addition, the terms "insanity" and "insane" are used commonly to describe soldiers suffering from various mental illnesses because that was the umbrella term for all these ailments within the military and asylum systems. Officers and physicians did not distinguish a soldier unable to cope with wartime experiences from a man who became insane for another reason, thus "insanity" is the label used widely. Because that is the term used within the nineteenth-century records, it is also used here to describe the soldiers examined within this research.

Instead of arguing the existence of trauma, the task becomes to discover how society and the medical community in the years surrounding the Civil War understood and treated soldiers who succumbed to symptoms we might recognize as Trauma today. Analyzing the problem of mental trauma and its treatment in a century that did not recognize mental collapse in the way we do today provides an opportunity to analyze the society and culture of the period. As Jalynn Olsen Padilla suggests in her work on amputees after the Civil War, historians often ignore medical diagnoses because of questions about anachronism; however, if you look at these diagnoses as social constructs, you can analyze the society and culture doing the constructing. ${ }^{6}$ Civil War America did not have our current understandings of the brain and trauma, and did not have a definition similar to PTSD. Their knowledge of the brain and insanity resulted from a combination of traditional medicine, the rise of scientific medicine, and the influence of

\footnotetext{
${ }^{6}$ Jalynn Olsen Padilla, "Army of 'cripples': Northern Civil War Amputees, Disability, and Manhood in Victorian America," (Ph.D. Dissertation, University of Delaware, 2007), 8.
} 
evangelical reformation. By the mid-nineteenth century, medicine was becoming more scientific, as seen in the experimentation and record keeping done by physicians during the war, but there was still a reliance on older practices, such as bleeding, cupping, and understanding illness as an imbalance of the body's fluids or considering symptoms as the illness itself instead of signs of a deeper problem. The rise of reform movements in the antebellum period, such as prison reform, and the idea that people can be "redeemed," both in a religious and social context, led to new institutions to care for the insane and the rise of a new medical discipline, psychology. Within these new institutions, the insane were treated with a combination of tonics and treatments from traditional medicine and "moral treatment," a regimen of exercise, occupation, and moral activities in order to restore mental health. Asylum superintendents and physicians considered insanity as resulting from two main causes, physical causes — or heredity — and moral causes, essentially believing that men and women could lose their minds due to breaking the natural laws of society and could be brought back to health through a proper, moral environment.

At the start of the Civil War, these new asylums were the main option for soldiers who became insane during the war. Following the asylum movement of the antebellum period, the government and military opened the Government Hospital for the Insane (GHI) in Washington, D.C. in 1855 to care for members of the Army and Navy. This asylum saw over 1,300 admissions during the war, whereas between 1855 and 1861 the asylum had treated a total of 439 patients. ${ }^{7}$ However, military officials and asylum physicians continued to see wartime insanity as

\footnotetext{
${ }^{7}$ Reports of the Board of Visitors and the Superintendent of Construction of the Government Hospital for the Insane, for the year 1860-1861 (Washington: Gideon \& Pearson, Printers, 1864), 3-4. Reports of the Government Hospital for the Insane, Vol. 1, 1855-1874. Office of the Chief Clerk, Department of the Interior. Record Group 48, Entry 298, Box 6. National Archives, College Park. 1,300 number derived from admissions statistics within the yearly reports by the Board of Visitors and the Superintendent. Reports of the Government Hospital for the Insane, Vol. 1, 1855-1874. Office of the Chief Clerk, Department of the Interior. Record Group 48, Entry 298, Box 6. National Archives, College Park. One explanation for the drastic increase in admissions is the growth of the army in a time of war, although you do see a dramatic increase in the rate of admissions in the later years of the war.
} 
a result of heredity or physical and moral weakness. For the most part, medical and military personnel did not connect wartime insanity with the traumatic events witnessed and experienced on the battlefields and in camps. This resulted in limited options for treatment and recovery for soldiers who became mentally affected by the war.

This dissertation argues that Civil War America did not connect wartime trauma to mental illness and created policies based in the socially and medically grounded belief that insanity was caused by hereditary or moral weakness, and that in the post-war period Americans continued to understand insanity as caused by physical and moral influences. As a consequence, Civil War soldiers and veterans developed a coping culture to supplement official options of treatment and support to manage their wartime experiences. The official channels of treatment provided by the army, military physicians, and insane asylums necessitated unofficial coping methods among soldiers. Because soldiers experienced trauma that was not recognized or fully treated through the military or medical professionals, they developed individual and communal ways to process and cope with their wartime experiences. By relying on familiar support systems and cultural ideas such as family, religion, courage, ideas of death and the afterlife, and masculinity soldiers sought to put new and troubling experiences into familiar terms. Connections to comrades and loved ones at home provided a support system that filled in where the official system failed. In the same way that soldiers sought to make their physical environments and experiences more bearable, they used these coping methods to survive mentally and emotionally.

This fracture between official and unofficial treatment for mental trauma continued in the post-war period. While the Civil War ushered in a new era of scientific medicine on the eve of microbiological science, the mental effects of warfare remained largely unexamined. The largest 
Civil War studies of symptoms that could be connected to psychological trauma focused on physical conditions of the heart and nerves, particularly the works of S. Weir Mitchell and Jacob Da Costa; beyond that the insane remained in asylums under custodial care that still followed the ideas of "moral treatment." Even through the turn of the century and into the First World War, physicians and psychiatrists focused on the physical causation of mental breakdown, although that war saw some advances in acknowledgement and treatment. Consequently, veterans who sought treatment or pensions in the post-war period faced much of the same difficulty as during the war. With their ailments still largely unrecognized or seen only through a physical or moral lens, veterans used their families and veterans groups as support systems to continue managing the wartime experiences that continued to stay with them after the fighting ended.

Mental trauma during the Civil War and post-war period is a story of change under the surface of society. While officially, medical and military understandings of the mental and emotional damage caused by the war did not undergo large changes over this period, ordinary men developed a new coping culture to survive. The following chapters will follow the soldier in the experience of warfare and trauma through the wartime and post-war periods. Chapter one establishes the existence of trauma during the Civil War and explores how soldiers defined and reacted to these symptoms. Using scholarship on soldier experience and combat trauma, this chapter pairs the secondary literature with soldiers' letters and diaries, asylum records, and pension records to demonstrate how traumatized soldiers appeared during the Civil War and how they understood those symptoms. This initial chapter provides the base for the following discussions of treatment by the military, the medical field, and the soldiers.

Chapters two and three cover the wartime period, roughly 1861-1865. First, chapter two examines the official channels of diagnosis and treatment available to men within the Union 
army and mid-nineteenth century insane asylums. These official options include military policies and medical treatments concerning soldiers who exhibit the signs of trauma discussed in chapter one. The primary focus of analysis in this chapter is the writings of army medical officers, published military and medical policies, and the treatments followed at the GHI and state asylums. Not only does this chapter analyze the official treatment options available to Civil War soldiers, it establishes the basis for diagnosis and treatment as physical (or hereditary weakness) or moral failing. When these options were found lacking, men developed their own methods of coping to support themselves during the war, as analyzed in chapter three. These unofficial options, in contrast to the official treatments recognized by the military and medical field, were largely based in self-care and comradery. Soldiers used cultural activities and ideas-such as religion - to sustain themselves and built a network of support among their comrades. This culture of coping was interwoven in the camp culture often described by historians of the common soldier.

Chapters four and five follow the same pattern, covering the post-war period as veterans returned home to their communities. Chapter four explores the adjustment from soldier to veteran and demonstrates the continuation of trauma through asylum and pension records. In this post-war period, the official treatments shift from military policy to government support of veterans through pensions and other benefits systems, and medical care in post-war asylums. This chapter demonstrates that the government, medical field, and wider society continued to use physical and moral causation as the basis of policy about mentally ill veterans. Chapter five analyzes the expectations society had of returning veterans and how former soldiers filled in the gaps of these official channels in order to cope successfully with their wartime experiences in their transition to being veterans. This chapter argues that veteran's societies were at their core 
coping mechanisms for veterans that allowed them to retain the support system of comradery that they relied on during the war.

Research in the topic of mental trauma, insanity, and coping follows a trend in the historiography of the Civil War that look more closely at the experience of war from the ground up. Previous scholarship in this field looked at soldier experience through daily life, equipment, and the cultural norms of the armies and soldiers. Works such as Bell I. Wiley's Life of Billy Yank and Life of Johnny Reb and James I. Robertson, Jr.'s Soldiers Blue and Gray explored the daily experience of the Civil War soldier and turned the focus away from wide-sweeping battle narratives. ${ }^{8}$ New scholarship in this field focuses on the soldier experience in a more personal way and analyzes the connection between the battlefield and society. For example, Drew Gilpin Faust's This Republic of Suffering and Mark S. Schantz's Awaiting the Heavenly Country explore nineteenth-century America's understandings of death and how that both affected and was affected by the Civil War. ${ }^{9}$ Megan Bever analyzes the temperance movement within the armies and how soldiers used alcohol to shore themselves up both physically and mentally. ${ }^{10}$ Lesley Gordon's new take on a regimental history that uses a lens of cowardice and the experience of soldiering, and essay collections such as Stephen Berry's Weirding the War sit squarely within this new trend and illuminate new angles on the Civil War and the men fighting it. ${ }^{11}$ In uncovering the deep social, cultural, and personal experiences of the Civil War soldier,

\footnotetext{
${ }^{8}$ Bell I. Wiley, The Common Soldier of the Civil War (New York: Charles Scribner's Sons, 1975); Bell I. Wiley, The Life of Billy Yank: The Common Soldier of the Union (The Bobbs-Merrill Company, Inc., 1951, 1952); James I. Robertson, Jr., Soldiers Blue and Gray (Columbia: University of South Carolina Press, 1998).

${ }^{9}$ Drew Gilpin Faust, This Republic of Suffering: Death and the American Civil War (New York: Alfred A. Knopf, 2008); Mark S. Schantz, Awaiting the Heavenly Country: The Civil War and America's Culture of Death (Ithaca: Cornell University Press, 2008).

${ }^{10}$ Megan Leigh Bever, "War is a Terrible Enemy to Temperance: Drinking, Self-Control, and the Meaning of Loyalty in the Civil War," (Ph.D. Dissertation, The University of Alabama, 2014).

${ }^{11}$ Lesley J. Gordon, A Broken Regiment: The $16^{\text {th }}$ Connecticut's Civil War (Baton Rouge: Louisiana State University Press, 2014); Stephen Berry, ed., Weirding the War: Stories from the Civil War's Ragged Edges (Athens:
} 
these subjects become more human and in turn reveal new details about the wider society of nineteenth-century America. A criticism of this new scholarship is that it focuses on Civil War soldiers as "victims," looking only at the wounded, the dead, the broken in mind and spirit. However, this new scholarship does not replace or invalidate the scholarship of military bravery and national success, it merely adds a new dimension to it that recognizes the reality of war that our generation of historians understands implicitly.

The study of mental illness and trauma among Civil War soldiers and veterans is full of challenges. For example, Paul Cimbala cautions against the comparison of the Civil War to modern definitions of Post-Traumatic Stress Disorder. He argues that physical injuries could affect the mental state of veterans and historians cannot know the mental state of these soldiers without also knowing their pre-war minds. While he mentions trouble transitioning back home because veterans were unable to settle down or were experiencing issues, he argues that these could be caused by problems that were already there but worsened by the war. ${ }^{12}$ When he admits that some mental issues did occur among veterans, he writes "The unhappy nature of the battle and camp experiences of some men were too harsh or too abnormal to ignore as at least being contributing causes to mental breakdown in soldiers who were already fragile and vulnerable before they enlisted." ${ }^{\prime 13}$ He continues on to state that the "lingering physical problems resulting from wartime injuries and sickness could also easily contribute to the degeneration of mental health, especially having a wearing effect on weakened men who became troubled by their ill

The University of Georgia Press, 2011). Diane Miller Sommerville has an essay on mental illness in Confederate soldiers in this volume.

${ }^{12}$ Paul A. Cimbala, Veterans North and South: The Transition from Soldier to Civilian After the American Civil War (Santa Barbara, CA: Praeger, 2015), xv-xviii, 47-58.

${ }^{13}$ Paul A. Cimbala, Veterans North and South, 90. 
health over time." ${ }^{14}$ Cimbala takes the same argument as nineteenth century physicians that mental trauma was the result of men who were already weak or physically ill. ${ }^{15}$

While Cimbala is correct that the majority of veterans probably did readjust to civilian society, some did not and even veterans who did transition could experience symptoms of trauma. Successful readjustment to civilian life and mental trauma are not exclusive, veterans suffering from trauma can still work successfully in society. While the research represented in this study features a minority of soldier experiences, primarily those soldiers who ended up in an insane asylum or committed suicide, the subject of trauma is far more reaching than those soldiers who broke down under the stress of battle. The environment of war that causes some soldiers to break down is experienced by all soldiers in the field and they all must find ways to cope with the same events. In addition, the breakdown of one solider could distress the men within their mess or regiment. Watching a comrade suffer the symptoms of insanity or learning a friend committed suicide affected soldiers who managed to cope with their wartime experiences and forced them to reevaluate what they understood about insanity, masculinity, and bravery. The experience of trauma is representative of the experience of the Civil War, for both those who broke down and those who coped.

Scholarship on the traumatizing experience of war and how Civil War soldiers understood and coped with it is a newly emerging field. For several years, Eric T. Dean, Jr.'s 1997 work Shook Over Hell stood alone in directly connecting twenty-first century definitions of Trauma, namely Post-Traumatic Stress Disorder (PTSD), back to the Civil War. Dean compares the Civil War and Vietnam to prove that PTSD existed long before the modern era. In this work he analyzes the trauma men experienced on the Civil War battlefield, how they reacted to it, and

\footnotetext{
${ }^{14}$ Ibid.

${ }^{15}$ Paul A. Cimbala, Veterans North and South, xv-xvii.
} 
how the army officially diagnosed and treated these casualties. In doing so he argues that elements of the Civil War's "nostalgia" and "irritable heart" were the same as the "shell shock" of the World Wars and the PTSD of Vietnam. He uses soldier accounts to pinpoint symptoms of mental stress and anecdotes to support his analysis, while his primary evidence comes from a sampling of Indiana veterans who were treated in insane asylums after the war. While this analysis suggests that there is a connection between Civil War soldiers and Post-Traumatic Stress Disorder and sheds light on the mental experience of the warfare in nineteenth-century America, the work did more to show that there was a reaction than explain why the reaction occurred. $^{16}$

Other works contemporary to Dean began to skirt around those edges, examining soldier experience and fortitude. Published the same year, Earl J. Hess' The Union Soldier in Battle moved the question to how soldiers dealt with battle, although he argues that soldiers were able to successfully cope by centering their values around courage ${ }^{17}$ Reid Mitchell's The Vacant Chair analyzes the soldiers' connections to home, how leaving home sometimes changed the men while at the same time connections to home sustained them during the war, and James M. McPherson's For Cause and Comrades looks at soldier motivations to fight in the war, not just to enlist, but to endure the hardships of four long years. ${ }^{18}$ Additionally, Gerald Linderman's Embattled Courage argues that the war inevitably changed the Civil War soldier, using the core value of courage as his base of analysis, and highlights the disillusionment of the soldier and the

\footnotetext{
${ }^{16}$ Eric T. Dean, Jr., Shook Over Hell: Post-Traumatic Stress, Vietnam, and the Civil War (Cambridge, MA: Harvard University Press, 1997).

${ }^{17}$ Earl J. Hess, The Union Soldier in Battle: Enduring the Ordeal of Combat (Lawrence, KS: The University Press of Kansas, 1997).

${ }^{18}$ Reid Mitchell, The Vacant Chair: The Northern Soldier Leaves Home (New York: Oxford University Press, 1993); James M. McPherson, For Cause \& Comrades: Why Men Fought in the Civil War (New York: Oxford University Press, 1997).
} 
separation between the soldier and civilian experiences of the war. ${ }^{19}$ These works started to look at the experience of battle and how soldiers endured it, without making a direct connection to these being psychologically traumatic events. "Seeing the Elephant": Raw Recruits at the Battle of Shiloh, although slightly earlier than Dean's book, was perhaps closest to broaching the topic of trauma, analyzing the reactions to first combat by new soldiers at Shiloh. However, authors Joseph Allen Frank and George A. Reaves concluded that while these recruits did react to and comment on the horror of battle the events did not seem to affect them in the long term, essentially that the soldiers bounced back without lingering effects. ${ }^{20}$

Since there are few works on the Civil War that directly combine history and psychology to examine mental trauma, I utilized works outside the nineteenth century for context. John Keegan's Face of Battle analyzes battle from the ground level, attempting to see the "face" of battle as he says, and also sees change over time between combat experience and its impact on soldiers. He challenges traditional histories of warfare and claims that the history of war had too long been written through commanders, large-scale movements, and war aims. In contrast, he argues, soldiers see battle on a very different scale. They think of themselves as individuals or members of a small group within the larger action of war; this provides a narrower view of war and acknowledges that men do not act as mass blocks, but as individuals. ${ }^{21}$ Acts of War: The Behavior of Men in Battle by Richard Homes claims that Keegan did not push the boundaries of military history far enough and argues against Keegan's optimistic conclusions that battle would abolish itself. Holmes departs from a strictly historical view of soldier experience and utilizes

\footnotetext{
${ }^{19}$ Gerald F. Linderman, Embattled Courage: The Experience of Combat in the American Civil War (New York: The Free Press, 1987).

${ }^{20}$ Joseph Allen Frank and George A. Reaves, "Seeing the Elephant": Raw Recruits at the Battle of Shiloh (Urbana, IL: University of Illinois Press, 1989).

${ }^{21}$ John Keegan, The Face of Battle (New York: Penguin Books, 1976).
} 
psychology to analyze what soldiers see and experience in battle. Within Holmes' discussion of training, group mentality, and the experience of the battlefield, he pulls in psychology to explore the variety of ways men handle fear and stress, as well as analyzing the occurrence of psychological casualties. He acknowledges the concept that "every man has a breaking point," an idea that was not widely accepted in earlier literature. ${ }^{22}$ Analyzing a narrower focus is Joanna Bourke's An Intimate History of Killing: Face to Face Killing in $20^{\text {th }}$ Century Warfare. Killing is expected in war; however, Bourke claims that historians have remained preoccupied with experience and dying. Her goal is to put killing back into military history and examine how that action restructured social relationships, how men experienced it, and how it was folded into societal and cultural norms. Soldiers developed coping methods that were then supported by the military and society. For Bourke, killing in war was molded and supported by three groupssociety, the military, and soldiers - and was integrated into culture as a whole. ${ }^{23}$

In the same way historians have begun to use psychology in their works, some psychologists have used military history in their efforts to address how soldiers mentally cope with their service in war. Richard Gabriel takes a forlorn view of military psychiatry in his work No More Heroes: Madness \& Psychiatry in War. He believes that America has a very naïve view of war since we have not seen war on the same scale as most countries, nor have we had many wars that have occurred on our own soil. Because of this naiveté society thinks that mental breakdown is a problem only experienced by our modern soldiers, and that this breakdown is the result of weakness or cowardice. Reality, he claims, is quite the opposite as warfare progresses to a point that he argues human beings cannot possibly withstand. Humans are the lynchpin of military success; no matter how good the strategy or technology, when men collapse under the

\footnotetext{
${ }^{22}$ Richard Holmes, Acts of War: The Behavior of Men in Battle (New York: The Free Press, 1985).

${ }^{23}$ Joanna Bourke, An Intimate History of Killing: Face to Face Killing in $20^{\text {th }}$ Century Warfare (BasicBooks, 1999).
} 
strain military effectiveness diminishes. The reactions and symptoms he addresses in his work are critical in the rise of military psychiatry because humans are the basic element of warfare. Unless military authorities find a way to alter human beings at a fundamental level, the same problems will occur in future wars. ${ }^{24}$ These works, and others, provide a framework for combining history and psychology to examine the soldier experience and mentality. ${ }^{25}$

With the emergence of "dark turn" scholarship, Civil War scholars are taking up this train of thought and examining the trauma of war in the nineteenth century by exploring multiple angles of this topic. Brian Matthew Jordan's work Marching Home weaves the idea of trauma, coping, and an "unending war" into his narrative on how veterans sought to reintegrate into their homes and northern society. ${ }^{26}$ Kathryn Shively Meiers' Nature's Civil War examines how soldiers used "self-care" to keep themselves physically healthy in the army in response to the inadequacy of official means to provide food, shelter, and medical care. While she focuses on this kind of "physical coping," her work provides a framework in which to see mental coping in the same way. ${ }^{27}$ Historians have also developed a sub-field in suicide studies in the nineteenth century; David Silkenat's book on Civil War suicide focuses on the changes in how North Carolinian society viewed the subject, Diane M. Sommerville's research focuses on post-war suicides the South and their social and gender implications, and Richard J. Bell writes on the

\footnotetext{
${ }^{24}$ Richard A. Gabriel, No More Heroes: Madness \& Psychiatry in War (New York: Hill and Wang, 1987).

${ }^{25}$ See also: Peter Watson, War on the Mind: The Military Uses and Abuses of Psychology (New York: Basic Books, Inc., Publishers, 1978); Peter G. Bourne, Men, Stress, and Vietnam (Boston: Little, Brown and Company, 1970); Elmar Dinter, Hero or Coward: Pressures Facing the Soldier in Battle (Totowa, NJ: Frank Cass and Company Limited, 1985).

${ }^{26}$ Brian Matthew Jordan, Marching Home: Union Veterans and Their Unending Civil War (New York: Liveright Publishing Corporation, 2015).

${ }^{27}$ Kathryn Shively Meier, Nature's Civil War: Common Soldiers and the Environment in 1862 Virginia (Chapel Hill: The University of North Carolina Press, 2013).
} 
discussions of suicide in antebellum society and argues that antebellum Americans used suicide in discussing many social concerns and a perceived suicide epidemic. ${ }^{28}$

These works reflect our current society where scholarship taken a definite cultural turn and the idea of the traumatized soldier is engrained in modern society. Since the Vietnam War and the official diagnosis of Post-Traumatic Stress Disorder, the idea that war is catastrophically traumatic to the human psyche is well-established and psychologists and historians have started to look back at previous wars to make connections to these newly established ailments. ${ }^{29}$ This scholarship adds a new dimension to the military history of the Civil War by examining individual experiences of war and the mental effect of warfare on the men who fought it. The analysis in this dissertation lies at the juncture of these various lines of historiography.

Combining psychology, studies of soldier experience and coping both within and outside the Civil War, medical studies, cultural studies, and an analysis of the soldiers' own words, this work seeks to bring these strains of analysis together to an intersection that illuminates the traumatizing effect of war on the Civil War soldier and how they handled that experience within the social, cultural, and medical understandings of the period.

In order to approach this research through an interdisciplinary lens, I utilized psychological theories of coping, particularly within the military, from the past few decades to

\footnotetext{
${ }^{28}$ David Silkenat, Moments of Despair: Suicide, Divorce \& Debt in Civil War Era North Carolina (Chapel Hill: The University of North Carolina Press, 2011); Diane Miller Sommerville, “'Cumberer of the Earth': Suicide and Faith in the Post-Civil War South," in Death in the American South, edited by Craig Thompson Friend and Lorri Glover (New York: Cambridge University Press, 2014), 153-180; Diane Miller Sommerville, “'A Burden Too Heavy to Bear': War Trauma, Suicide and Confederate Soldiers," Civil War History 59, no. 4 (December 2013): 453-491; Diane Miller Sommerville, "Will They Ever Be Able to Forget?: Confederate Soldiers and Mental Illness in the Defeated South," in Weirding the War: Stories from the Civil War's Ragged Edges, edited by Stephen Berry (University of Georgia Press, 2011), 321-339; Richard Bell, We Shall Be No More: Suicide and Self-Government in the Newly United States (Cambridge, MA: Harvard University Press, 2012).

${ }^{29}$ See also, Judith Anderson, “'Haunted Minds': The Impact of Combat Exposure on the Mental and Physical Health of Civil War Veterans," in Years of Change and Suffering: Modern Perspectives on Civil War Medicine, edited by James M. Schmidt and Guy R. Hasegawa (Roseville, MN: Edinborough Press, 2009), 143-158.
} 
identify cases of trauma and understand the mental process of witnessing and coping with warfare. Psychologist Ben Shalit used his experiences as a psychologist with the Israeli navy to examine the psychological reactions to combat. In his work, The Psychology of Conflict and Combat, he analyzes the stages of coping with stress and explains how this progression works within a military combat situation. This coping appraisal begins with determining what the situation is and ends with an ability to cope with that situation. A person must clear each step of the process before moving on to the next; if a step is insurmountable coping will not happen. There are many points where failure can occur and the most common symptom is neuropsychiatric dysfunction, or "battle fatigue," which can affect a quarter of combatants. This breakdown usually comes after repeated exposure to combat, not after the first battle; even though repeated exposure means soldiers can learn how to react, battle always presents new and confusing situations in which the individual must move through the entire appraisal and coping process with the possibility of failure. ${ }^{30}$

Additionally, On Killing: The Psychological Cost of Learning to Kill in War and Society by Lieutenant Colonel Dave Grossman also combines a background of psychology with military service. He argues that humans are reluctant to kill each other, creating stress when they are placed in a situation where killing other humans is required and demanded. Grossman says that psychological breakdown is not a result of a single thing, that the conflict over killing combines with fear of death and injury, exhaustion, hate, and horror to create wartime trauma and stress. Armies and individuals have tried to counter this in several ways, through training and conditioning, absolving men of their actions through orders and group action, and creating emotional distance between soldiers and their enemies. Unfortunately, these strategies often fail

\footnotetext{
${ }^{30}$ Ben Shalit, The Psychology of Conflict and Combat (New York: Praeger Press, 1988).
} 
or fall apart, chipping away at a soldier's "well of fortitude" until they have nothing left to support themselves. Once a soldier's inner strength is gone, they will become a psychological casualty and if they cannot reach the final stage of acceptance and rationalization over the killing they have done, that damage may remain as Post-Traumatic Stress Disorder. ${ }^{31}$

A third theory, the interpersonal-psychological theory of suicide introduced by Thomas Joiner in his 2005 work Why People Die By Suicide, provides insight into coping and suicide. There are many people who feel or exhibit signs of suicidality, but very few commit the action. This is because there are three variables to a successful suicide-perceived burdensomeness, failed belongingness, and the capability for self-harm — and without all three a suicide will fail. The first two factors deal with the interactions and connections between people, both of which Joiner identified as "fundamental needs." Humans need to interact with others as well as feel cared for; simple connections with many people and deep connections with specific people are very important. These relationships are mutual; when a person feels ineffective, helpless, and unable to contribute a sense of burdensomeness develops. Perceived burdensomeness and failed belongingness constitute the desire for death (which most people feel at some time in their life), but not the ability. This is the third variable: acquired capability for self harm. A body's natural instinct of self-preservation is very difficult to overcome, even if the desire to die is present; however, if a person becomes used to danger and self-injury (whether through harming themselves in gradually worse ways or being exposed to dangerous situations) then the danger signals that should accompany self-harm no longer occur. The destruction of this natural barrier

\footnotetext{
${ }^{31}$ Dave Grossman, Lt. Col., On Killing: The Psychological Cost of Learning to Kill in War and Society (New York: Back Bay Books, 2009).
} 
allows those with the desire to die to actually go through with it; without it the idea would be dismissed or attempts would fail. ${ }^{32}$

These theories, as well as current research on Post-Traumatic Stress Disorder, provide an understanding of how the brain works and how humans exhibit signs of trauma that reveal similarities between the Civil War and current conflicts. This is not to say that nineteenthcentury soldiers understood any of these processes in the same way that we do now, only that modern theory provides a framework in which to understand the mental and physiological process of stress which psychologists claim has not changed through the years. According to these theories the mental and physiological effects of stress and combat have not changed because the brain functions the same way physically; instead, it is our understanding of the brain and the medical treatment of these symptoms that has changed over time. Throughout this research, I have sought to use current theory as a guide, but avoided transposing it on the words and actions of Civil War actors. With the idea that Civil War soldiers faced the same physical and mental effects of warfare as modern soldiers, the real analysis comes in exploring the difference in how soldiers reacted to their conditions and how wider society understood what was happening to soldiers. By placing soldier cases that suggest mental trauma as understood by current society into their nineteenth-century society we can analyze the medical and cultural concepts of trauma and mental illness at the time. As a result, patterns of treatment and coping are revealed within official and unofficial channels that speak to the culture and medical practice of the nineteenth century.

While an examination of mental trauma during the Civil War, particularly with the use of psychology, can be complicated and walk the fine line of anachronism at points, it is beneficial

\footnotetext{
32 Thomas Joiner, Why People Die By Suicide (Cambridge: Harvard University Press, 2005), 46-136.
} 
to modern scholars of the Civil War to explain the military, cultural, and medical environment surrounding the ordinary soldier. It expands our understanding of the Civil War soldier, particularly why he made decisions and how he managed his experiences. Recognizing the mental process to understand and cope with the new experiences soldiers faced will perhaps explain why soldiers acted the way they did or why battles ebbed and flowed in certain ways. In addition, these studies will further illuminate the environment of war men had to contend with in the Civil War, based off of their reactions to it. By examining medical treatments of insane soldiers, nineteenth century medical knowledge of trauma and the brain is revealed, and the Civil War can be placed in a historical timeline of medical change and transition. Examining official military procedure for insane soldiers reveals the priorities of the military and the predominant cultural expectations of male soldiers. Comparing these "official" ideas of medicine, military, and cultural expectations to how the soldiers reacted to their environment and experiences reveals cultural and personal transformations on the ground level. Faced with new and confusing situations, Civil War soldiers had to adapt and cope in order to manage and survive their experiences. 


\section{$\underline{\text { A Note on Research }}$}

Trauma and coping among soldiers can be difficult to find overtly stated in nineteenthcentury records. Because of the contemporary understandings of mental illness, masculinity, medicine, and social behavior Civil War soldiers, officers, and physicians saw mental trauma completely different than current soldiers and doctors. Instead of writing about their experiences and reactions with knowledge of psychological theory, these soldiers wrote about their time as soldiers by referencing the social, cultural, and medical ideas they were familiar with. Thus the signs of trauma and coping are found within the writings of soldiers in small hints and nuances that suggest these men struggled to comprehend and cope with the experiences on hand.

In order to find cases of possibly traumatized soldiers I utilized adjutant reports, pension records, and the patient records of insane asylums. I focused on Union soldiers because of the wealth of resources for that population—-specifically the records of the Government Hospital for the Insane, federal pensions, and larger numbers of consolidated military records - and the fact that several other scholars are researching trauma, suicide, and veterans in the Confederacy and post-war. By keeping to the Union states, the official and unofficial records allowed for the uncovering of both official and unofficial methods of treatment and coping both during and after the war. A search of the adjutant reports of several Union states revealed soldiers listed as insane, patients in asylums, or those who committed suicide. While these searches did not find every single soldier who fell into those categories, it did provide a sample of soldiers to investigate further. Overall, I found 461 soldier cases that were either suicides (109) or soldiers with asylum admission in their records (352). In this sample, there were 289 soldiers from New York, 82 from Ohio, 34 from Pennsylvania, 27 from Illinois, and 29 from various other states, with soldiers from all three branches of the army representing a wide range of ages and backgrounds. 
While not perfectly proportional to the numbers of soldiers furnished by each state, I did focus on the states with the largest enlistment in this sample. Of these 461 cases, 144 had asylum files or records and 115 had pension files, and these cases provide the core of my analysis.

Asylum records proved more fruitful, but also more difficult. Primarily these records were admission and patient records that provided information on the patient's history, symptoms, and treatment in a varying level of detail. On the positive side, these asylum records provided evidence of how asylum physicians viewed, diagnosed, and then treated their patients during and after the war and revealed details of the symptoms suffered by the incoming men. On the other hand, because medical professionals did not recognize trauma connected to military service, many (if not most) soldiers or veterans admitted into the asylums were not marked as such, making it difficult to pinpoint these cases. In addition, most of these patient records are secured under the Health Insurance Portability and Accountability Act of 1996 (HIPAA) so access was severely limited and in most cases I had to sign confidentiality forms promising to protect the identities of my case subjects.

The result of this is that I must conceal the identities of many of the soldiers used in this research within this work. I cannot use their names, initials, or any other information which would reveal their identities. Those soldiers whom I name in the following pages were not case studies from any of the asylum records, usually coming from the adjutant reports, and those left unnamed are done so because of these privacy and confidentiality restrictions. This led to a particular quandary when it came to citing my research in the footnotes, particularly the pension records of these individuals. The standards of historical writing require a full citation of sources to hold the researcher accountable and allow other scholars to utilize the same sources, but the confidentiality agreements prohibited me from sharing any identifying information. 
Consequently, when dealing with a soldier identified in one of the sets of asylum records, I cited both the asylum records entries and pension records using only the file record numbers, allowing future researchers to find the same records but not revealing any identities within my writing. ${ }^{33}$

After identifying possible cases from the adjutant reports and asylum records, I delved into the pension records of these soldiers for clues about their service, symptoms, and success in seeking a pension. These records were particularly valuable in the depositions and testimonies often required from comrades to prove injury or disability; in many of these files, fellow soldiers described the breakdown of the pensioners and symptoms that pointed to trauma or mental injury. In addition, testimony of family and friends described the changes they saw in their loved ones and the symptoms they witnessed within their own homes. The pension records also revealed patterns of success and failure to obtain a pension in cases of mental illness, insanity, and suicide. To find further indications of trauma and analyze the coping methods of Civil War soldiers, I read letters and diaries to see how soldiers described the conditions of soldieringsuch as camp life, the march, and battle - and if they expressed any of their reactions to these events. I focused primarily on wartime letters and diaries to capture the soldier's feelings in close proximity to the event and avoided postwar memoirs or edited diaries where veterans had added to or revised their writing.

\footnotetext{
${ }^{33}$ In the case of asylum records, the numbers are the case file numbers or the pages within the case books where the patient record can be located. In the case of pension files, the numbers are the pension file record numbers which are used to locate and request the file from the National Archives.
} 


\section{Chapter One:}

"The Strain on Our Minds and Bodies had been Severe":

\section{The Traumatic Experience of Civil War Soldiering}

"Somewhat disheartened \& low spirited we are back again on the safe side of the Rappahannock but Mother I am so sad I can hardly write. I have just visited what there is left of the $26^{\text {th }}$ Regt." Writing days after the Battle of Fredericksburg, Virgil W. Mattoon listed the battle's casualties among his friends and acquaintances in this neighboring regiment, lamenting that "Lieut. Willard Holstead alone remains of our Vienna boys to tell the tale." ${ }^{1}$ Writing to his parents about his first combat at the Battle of Frederickstown a year earlier, William T. Shepherd reflected that "My visit to the field of action the next morning was a sad one indeed-My blood chilled almost at the terrible sights." ${ }^{2}$ Describing the dead in their various forms, some peaceful, others gruesome, Shepherd tried to convey the experience to his readers at home. "Never did I think of — or realize the horrors of a battlefield till that morning_-, Shepherd admitted, "and I hope for no more to convince me of the truth." 3 Both Mattoon and Shepherd wrote home to communicate with loved ones the outcome of the battle and their own safety, but in doing so revealed the emotional impact the war had on them. These traumatic experiences stayed with soldiers like Mattoon and Shepherd, sometimes as terrible memories, and sometimes as more permanent mental and physical ailments.

The definition and acceptance of trauma in soldiers is relatively recent with the diagnosis of Post-Traumatic Stress Disorder and Traumatic Brain Injury. Previous definitions, such as

\footnotetext{
${ }^{1}$ Virgil W. Matoon (24 $4^{\text {th }}$ New York) to mother, "In pine woods two miles from Falmouth," Wednesday Evening, December $10^{\text {th }}, 1862$ (passage in question comes in the section from December $16^{\text {th }}$ ). Fredericksburg \& Spotsylvania NMP Collections, New York Manuscripts, Volume 254.

${ }^{2}$ William T. Shepherd, To Rescue My Native Land: The Civil War Letters of William T. Shepherd, First Illinois Light Artillery. Edited by Kurt H. Hackemer (Knoxville: The University of Tennessee Press, 2005), 93-94. Emphasis his.

3 Ibid.
} 
"shell shock," were somewhat accepted in the military community, but there were limits to treatment options and an emphasis on keeping soldiers on the front lines. Despite these recent definitions, however, many psychologists believe that combat trauma affected soldiers through history, even before they could understand the concept or the symptoms. Historian Richard Gabriel argues that human reactions to warfare have been similar all the way back to ancient Egypt, Greece, and Rome, including symptoms of deafness and blindness, paralysis, fatigue, inability to concentrate, failure to eat or drink, feeling isolated or frustrated, physical symptoms of fear, going berserk in battle, and suicide. The technology and tactics used in battle have changed over time, altering the way humans fight in combat, but psychologists suggest that humans have physiologically responded in similar ways throughout human history. As Gabriel states, "It is important to understand the historical record of combat breakdown for the simple reason that while the technology of war has changed considerably over the centuries, the raw material of war — the men who must fight it—has changed little or not at all. Technology...will mean nothing if men cannot withstand the storm of battle." ${ }^{4}$ What has changed from ancient history to today, is the knowledge and understanding humans have about how they react to trauma. $^{5}$

Men and women must withstand battle and the full experience of soldiering in a physical, emotional, and mental sense. War is of course physical, but it is also a psychological struggle in which men seek to maintain their own mental health while weakening that of their enemy in order to convince them to retreat or ultimately surrender. "War means forcing one's own will on others by physical means," argues Elmar Dinter. "Its purpose, however, is not the killing of the enemy. He has to be made to believe that he is weaker and, later, that he is defeated, in order to

\footnotetext{
${ }^{4}$ Richard A. Gabriel, No More Heroes: Madness \& Psychiatry in War (New York: Hill and Wang, 1987), 68-69.

${ }^{5}$ Richard A. Gabriel, No More Heroes, 3-11.
} 
make him surrender. The dead and the injured are only a means to this end. At its core, war is a battle of minds." As a battle of minds, soldiers face an environment in which warfare constantly requires full mobilization of their personal resources. When the body reacts to stress, it mobilizes all its energy resources and shuts down nonessential functions in order to focus on survival. When the stressor ends, the body feels weakened as it tries to rebalance itself and return its systems to normal. In a situation where the stressor does not go away, for example in extended combat, the body is held at a heightened state for a longer period of time, exhausting its energy resources and making it difficult to regain balance. Because trauma and stress are different for every individual soldier, each person reacts differently to the situation of combat; however, every soldier is at risk of experiencing trauma and breaking down. ${ }^{7}$ Psychologists and historians have used a variety of imagery to convey the limited nature of a soldier's resources, from a bank account that a soldier constantly withdraws from to a "well of fortitude" that eventually runs dry. ${ }^{8}$

While historians have expanded studies of trauma to cover the conflicts of the twentieth century, many have been reluctant to continue that study into the nineteenth century because the cultural, medical, and social understandings of trauma, suicide, and warfare were very different compared to today. Establishing the existence of trauma among Civil War soldiers using modern research to identify the psychological and mental reactions common to all soldiers allows for the study of the cultural and medical understandings of trauma in the nineteenth century and a

\footnotetext{
${ }^{6}$ Elmar Dinter, Hero or Coward: Pressures Facing the Soldier in Battle (Totowa, NJ: Frank Cass and Company Limited, 1985), 9.

${ }^{7}$ Lt. Col. Dave Grossman, On Killing: The Psychological Cost of Learning to Kill in War and Society (New York: Back Bay Books, 2009), 67-72; Richard A. Gabriel, No More Heroes, 73-74; also see Ben Shalit, The Psychology of Conflict and Combat (New York: Praeger, 1988).

${ }^{8}$ See: Lt. Col. Dave Grossman, On Killing, 82-85 for "well of fortitude"; Richard Holmes, Acts of War: The Behavior of Men in Battle (New York: The Free Press, 1985), 213-214 for the analogy of a bank account; and Elmar Dinter, Hero or Coward, 60-61 for imagery of a "cloud of pressures" and the "lake of complete psychical and psychological exhaustion."
} 
deeper analysis of how Civil War soldiers reacted to their experiences. Compared to the experience of warfare across the centuries of human history, Civil War soldiers experienced many of the same things: the emotions of being away from home and facing daily danger, the deprivation and uncleanliness of campaigning, and the stress of combat. In most cases, soldiers face two main sources of stress: the continual hardship of soldiering and campaigning, which is a constant stressor, and the spikes of stress experienced with combat or other extreme situations. Both put the soldier under stress and can affect them mentally and physically, causing mental trauma and necessitating different forms of coping. ${ }^{9}$

For soldiers, leaving home and entering a world far different from civilian life, change came rapidly and without mercy. Soldiers went through a psychological evolution from civilian to volunteer to soldier as they coped with the challenges of war, each step changing them more and taking them further from their civilian lives. This process included suppressing pre-war identities and creating new ones, identities based on professionalism and a certain amount of callousness in order to survive the war. The gateway to this process was what Gerald Linderman called a "simmering down" that manifested itself in several forms. As volunteers entered into the service they discarded unnecessary equipment and non-essential items to make their gear as light as possible on the long marches. In addition, the first casualties of most regiments were from disease, a "simmering down" process that thinned out the ranks. Initially, soldiers welcomed this process for they saw it as ridding the army of the weak and the cowards: New Yorker George Newcomb noted in 1862, "Eney [sic] new Regt has to go through the culling process before it will become a good and efficient Regt." ${ }^{10}$ As the process continued, however, and even the

\footnotetext{
${ }^{9}$ Dave Grossman, Lt. Col., On Killing, 69-72.

${ }^{10}$ Mark H. Dunkleman, Brothers One and All: Esprit de Corps in a Civil War Regiment (Baton Rouge: Louisiana State University Press, 2004): 115.
} 
bravest men died, soldiers felt their own vulnerability. ${ }^{11}$ Men adapted to their changed lives at different rates, some defining themselves as soldiers quickly, others becoming frightened by the changes they saw in themselves.

In addition, the daily experience of soldiering could wear down a man both physically and emotionally. Soldiers primarily marched from place to place, sometimes ten or more miles a day, with few or no breaks, often for many days in a row. Impending battle created the necessity for forced marches, with increased length and speed and no time for exhaustion. The elements were another factor as soldiers were often exposed to the weather without enough protection while on the march or being transported, in camp, and in battle. ${ }^{12} \mathrm{O} . \mathrm{W}$. Norton complained of one night when the rain "commenced to pour down, and the water ran through our tent, round it, and under it, and we just had to lie in a puddle of it all night ... scarcely a dry spot in the tent."13 Clothing and tents were sometimes in short supply or bad condition, and at times fires were forbidden for fear the enemy would spot them, depriving soldiers of warmth and hot food. Fighting near Winchester in 1863, Charles Lynch wrote in his diary for June 13: “The night was a very dark, stormy one, with severe lightning and thunder. We were wet through. Not allowed fires as it might draw the enemy's fire. Passed an uncomfortable night." ${ }^{14}$ The presence of a fire did not necessarily mean comfort, however, as evidenced by an October 1862 diary entry by Cyrus F. Boyd who complained, "Had no blankets with us and we suffered much last night in the cold rain[.] We could not sleep and had to stand up about all night around a little fire which we

\footnotetext{
${ }^{11}$ Gerald F. Linderman, Embattled Courage: The Experience of Combat in the American Civil War (New York: The Free Press, 1987), 113-116, 245-247; Reid Mitchell, Civil War Soldiers: Their Expectations and Their Experiences (New York: Viking Penguin Inc., 1988): 56-57; Earl J. Hess, The Union Soldier in Battle: Enduring The Ordeal of Combat (Lawrence, KS: The University Press of Kansas, 1997): 157, 185.

${ }^{12}$ Reid Mitchell, Civil War Soldiers, 59-60; Eric T. Dean, Jr., Shook Over Hell: Post-Traumatic Stress, Vietnam, and The Civil War (Cambridge, MA: Harvard University Press, 1997): 46-50.

${ }^{13}$ O.W. Norton to "Sister L," April 21, 1862. SoldierStudies.org, accessed November 12, 2011.

${ }^{14}$ Charles H. Lynch, diary, June 13, 1863. SoldierStudies.org, accessed November 29, 2011.
} 
tried to keep alive." ${ }^{15}$ Charles Wright Wills also complained of the soaking rain and the cold turning his fingers blue, but the consolation was that it stopped the chiggers from biting. In addition to the chiggers, the "ants also have an affinity for human flesh and are continually reconnoitering us," wrote Wills, "I kill about 200,000 per day. Also, knock some 600 worms off of me ... I pick enough entomological specimens off me every day to start a museum.”16 Conditions in camp led to uncleanliness and insect infestations, a humiliation for men accustomed to better circumstances, and this environment facilitated the spread and ravages of disease. $^{17}$

While these daily experiences were a constant stress on the soldier, the experience of battle was a major change for most of these new soldiers and it shows the effects of stress on the body more clearly than the continual wear of soldiering. The psychological cycle of combat includes anxiety before combat as the body and mind react to the increase in stress, an adrenaline-induced state during battle in which the soldier focuses on the essential tasks at hand, and the rebound after combat in which the soldier feels the physical effects of the heightened state and the body seeks to rebalance itself. While current psychologists have shown this cycle in studies of the body in twentieth- and twenty-first century soldiers, the same reactions can be seen with Civil War soldiers by studying their reactions to wartime experiences. ${ }^{18}$

Green recruits worried that the war would end before they saw combat and expressed a desire to see battle. Stimulated by desires to demonstrate their honor and manhood, new soldiers wanted to experience their first battle in order to prove themselves. Their eagerness soon

\footnotetext{
${ }^{15}$ Mildred Throne, ed. The Civil War Diary of Cyrus F. Boyd, Fifteenth Iowa Infantry, 1861-1863 (Baton Rouge: Louisiana State University Press, 1953): 78.

${ }^{16}$ Charles Wright Wills, entry for June 13, 1864. SoldierStudies.org, accessed November 14, 2011.

${ }^{17}$ Reid Mitchell, Civil War Soldiers, 59-60; Eric T. Dean, Jr., Shook Over Hell, 51-52.

${ }^{18}$ Dave Grossman, Lt. Col., On Killing, 69-72.
} 
changed as they experienced the worst anxiety before battle, as they moved into the vicinity of combat. Seeing the wounded streaming to the rear, the refuse of war strewn on the ground, and hearing the sounds of combat while not being personally engaged was tough on men preparing themselves for battle. "It is worse for a soldier to wait for a battle to begin than it is to do the fighting," admitted one man. ${ }^{19}$ Private George Hitchcock of the $21^{\text {st }}$ Massachusetts Infantry wrote in his diary for December 13, 1862 (Fredericksburg), that at nine that morning his regiment was ordered into position in the city to assault Marye's Heights. While waiting for orders on a sidewalk in town, he remembered, "This is the time that tries men's courage. Few words are spoken by any one. A few reckless ones improve the minutes by eating their rations, but most are looking into each others faces in silence, wondering, no doubt, if they have come to the end of their earthy career." ${ }^{20}$ He continued on, "At no time in all the horrors of the day was there such a sickening sense of war's realities while we awaited the orders sure to come."21 It is during this period of combat that the soldier can think upon the danger to come, the fear of the unknown, and uncertainty of their fate in battle. With their imaginations filling in what might happen, the soldiers could only wait anxiously for the order to move forward.

Artillery bombardments were especially intense for waiting soldiers. "Nothing is more trying to the nerves," wrote infantryman William P. Lyon, "than . . to have to remain silent and motionless under a fire which they are not permitted to return." 22 The explosion of shells was loud and visible to the men, and they could not move or react in any way. An ideal expression of courage was to receive such fire without moving, but many soldiers instinctively ducked at each

\footnotetext{
${ }^{19}$ James M. McPherson, For Cause and Comrades: Why Men Fought in the Civil War (New York: Oxford University Press, 1997), 38.

${ }^{20}$ Ronald Watson, ed. From Ashby to Andersonville: The Civil War Diary and Reminiscences of Private George A. Hitchcock, $21^{\text {st }}$ Massachusetts Infantry (Campbell, CA: Savas Publishing Company, 1997), 51.

${ }^{21}$ Ronald Watson, ed. From Ashby to Andersonville, 52.

${ }^{22}$ William P. Lyon to the Racine Advocate, May 10, 1862. SoldierStudies.org, accessed November $12,2011$.
} 
shell. ${ }^{23}$ Reflecting on his first combat experience in June 1863, John H. Westervelt was proud that they had tested their courage and "behaved like old hands at the business." ${ }^{24}$ Even so, as he was describing their reactions under fire he admitted, "Let me tell you this laying under fire and being unable of returning it is awfully trying to the nerves of a good man." ${ }^{25}$ Writing in his diary about the second day of Shiloh, Alexander Downing wrote, "It was very trying for us to stand in line of battle, shells exploding over our heads and cutting off limbs of trees, spent minie balls flying all about us, yet not being able to get into action..."26 These early periods of battle as soldiers waited to engage in combat were the most trying because soldiers could think upon the stressors of battle, but not react to them in a way that relieved the stress. One of the basic mechanisms for coping with a stressful situation is to act upon it in order to change the situation or attack the source of the conflict. While waiting in line of battle to attack or experiencing an artillery bombardment, soldiers felt the conflict of being in a stressful situation without the ability to react against it. ${ }^{27}$

The length of time soldiers had to wait with the psychological pressure of an upcoming battle on their minds affected the resulting stress and trauma. William T. Shepherd noted the different between engagements where they had to wait to enter battle and where they had immediately entered the field: "At that place [Belmont] we had an opportunity to think of what we were to engage in, while at F. [Frederickstown] we had no time to think but went immediately into action." "At Belmont we heard volleys of musketry and the booming of

\footnotetext{
${ }^{23}$ Gerald F. Linderman, Embattled Courage, 21; Eric T. Dean, Jr., Shook Over Hell, 43, 53-54, 63-64; James M. McPherson, For Cause and Comrades, 31, 38.

${ }^{24}$ John H. Westervelt. Diary of a Yankee Engineer: The Civil War Story of John H. Westervelt, $1^{\text {st }}$ New York Volunteer Engineer Corps, edited by Anita Palladino (New York: Fordham University Press, 1997), 21.

${ }^{25}$ Ibid.

${ }^{26}$ Alexander G. Downing, diary entry for April 7, 1862. SoldierStudies.org, accessed June 19, 2012.

${ }^{27}$ Ben Shalit, The Psychology of Conflict and Combat, 17.

${ }^{28}$ William T. Shepherd, To Rescue My Native Land, 104.
} 
cannon for an hour before we fired our pieces," Shepherd explained, "and it required a great deal of courage to march into the woods with our pieces - momentarily expecting to be fired on from a masked battery." 29 Relatively early in his service Shepherd realized that the waiting period before a battle could heighten the stress of combat compared to a situation where the soldiers immediately entered the fray.

Once they entered the surreal world of combat soldiers stepped into an environment of chaos and disorder. The smoke, terrain, and confusion made it difficult for them to see the enemy, or even where they were going, and often made it difficult to maintain battle lines and command structure. Coming under fire, especially if a near-miss was experienced, could feel almost unreal. Soldiers were amazed that they could come out of such an environment unscathed, sometimes with bullets having passed so close to have left holes in clothing or equipment. Sounds assaulted their ears, the varying noises of shot and shell and the sounds of their comrades yelling or dying. Deaths on the battlefield were shocking and disillusioning to many soldiers.

Civil War era men were used to death as it occurred in the civilian world: comprehendible, neat, orderly, respectful and surrounded by ceremony and family. The deaths they now witnessed were the opposite: chaotic, random, sudden, and gruesome. ${ }^{30}$

The impact of battlefield fatality could be particularly severe when soldiers witnessed the close range deaths of family members, friends, or close comrades. ${ }^{31}$ Austin Carr of the $82^{\text {nd }}$ New York went to war with a friend from home, Fred, and their friendship continued through their

\footnotetext{
${ }^{29}$ Ibid.

${ }^{30}$ Bell I. Wiley, The Life of Billy Yank: The Common Soldier of the Union (The Bobbs-Merrill Company, Inc., 1951, 1952), 68-87; Earl J. Hess, The Union Soldier in Battle, 9-19, 24-25, 28-29, 38, 47-63; Eric T. Dean, Jr., Shook Over Hell, 57, 63-64, 73-74; Gerald F. Linderman, Embattled Courage, 124-127; Joseph Allen Frank and George A.

Reaves, "Seeing the Elephant": Raw Recruits at the Battle of Shiloh (Urbana, IL: University of Illinois Press, 1989), 82-110; See also, Cheryl A. Wells, Civil War Time: Temporality \& Identity in America, 1861-1865 (Athens, GA: The University of Georgia Press, 2005), 69, for discussion of "battle time."

${ }^{31}$ Eric T. Dean, Jr., Shook Over Hell, 73-74.
} 
military service. Austin was standing just behind his friend when a bullet ripped through Fred's side and bowels, a wound that Austin knew was fatal. Austin leaned over his friend and heard his last words, but had to leave him behind. Expressing a sense of brokenness and anguish at the thought of his friend lying ruined on the battlefield, Austin volunteered for burial duty the next morning in the hope of finding Fred's body. Unlike so many, he was fortunate enough to locate the remains: "And then-there he was-lying so still, my buddy, Fred, He had given all that was possible for a man to give, somehow I felt bitter in my heart against this thing called war." 32 Fred was lucky enough to be buried by a friend in an individual grave on the side of the hill away from the others, unlike most soldiers during the war. Austin would never forget the death of his friend: "I could scarcely bring myself to look upon his crude grave," he wrote, "tears gushed down my face in spite of all my efforts to stop them, and so I bid him goodbye and left him there to sleep. The bitter wound in my heart to last forever."33

On the other hand, for soldiers hardened to the experiences around them there came a point when they no longer seemed to care about human life. "We passed around, among the dead bodies and wounded soldiers," said Henry C. Lyon of the $34^{\text {th }}$ New York, "apparently no more affected than would we be if we saw a number of Dead Beavers." ${ }^{34}$ When writing about artillery fire, O. W. Norton was glad there were no women around for "[e]very time a shell exploded they would jump and think 'there goes death and misery to some poor fellow."' He and his comrades no longer thought that way for "we have grown so careless and hardened that we don't heed them. ${ }^{35}$ Death was ever-present in the lives of Civil War soldiers and some became indifferent

\footnotetext{
${ }^{32}$ Austin Carr diary (excerpted transcript). Army Heritage and Education Center, Carlisle, PA. The Harrisburg Civil War Round Table Collection, Box 7. The entries in this transcript are undated, so I could not determine which battle Fred died in.

${ }^{33}$ Ibid.

${ }^{34}$ Mark S. Schantz, Awaiting the Heavenly Country: The Civil War and America's Culture of Death (Ithaca: Cornell University Press, 2008), 106.

${ }^{35}$ O.W. Norton to "Sister L," April 21, 1862. SoldierStudies.org, accessed November 12, 2011.
} 
to it, sometimes to the point at which they could function normally, joke, and enjoy pranks in battle or even live among the dead on the battlefield. ${ }^{36}$ Cyrus F. Boyd wrote at Corinth on May 23,1863 , "Some of the men joke and laugh while they are laying out the dead and seek to think nothing of it How inhuman and wicked this thing called War It brutalizes men and crushed out all Christian feeling." "The scenes of blood and strife that I have been called to pass through during the months that are passed, and my 'baptism in blood,"” admitted infantryman Warren Freeman, "have nearly destroyed all the finer feelings of my nature." 38 This callousness towards the dead on the battlefield, particularly during battle, demonstrates a change that came over soldiers as they transitioned from the pre-battle waiting period to full emersion into combat.

Despite the chaotic environment of battle, many soldiers reported feeling no fear in the midst of combat — the anxiety disappeared and they were able to focus on their tasks, ignoring danger, bodily needs, and the passage of time. For many soldiers, entering battle was a release from the pre-combat anxiety in which they could not act against the cause of their stress. While dreading battle as it approached, a New Hampshire private stated that "it isn't long before you won't think or care whether you are in it or not ... for a man in the heat of battle thinks nor cares for nothing but to make the enemy run." ${ }^{39}$ As James McPherson points out, this was probably due to a rush of adrenalin produced from the high level of stress resulting from battle. Those men who overcame the initial "flight" reaction, turned into fighting machines so committed to battle that their actions have been labeled combat frenzy, fighting madness, or battle rage.

\footnotetext{
${ }^{36}$ Earl J. Hess, The Union Soldier in Battle, 82, 146-149; Reid Mitchell, Civil War Soldiers, 69-74; Gerald F. Linderman, Embattled Courage, 118-123, 241-243; Eric T. Dean, Jr., Shook Over Hell, 211.

${ }^{37}$ Mildred Throne, ed., The Civil War Diary of Cyrus F. Boyd, 52. Lack of punctuation in original.

${ }^{38}$ Warren H. Freeman to father, October 3, 1862. SoldierStudies.org, accessed November 29, 2011.

39 James McPherson, For Cause and Comrades, 39.
} 
Civil War soldiers did not know about the body's chemical reactions to stress or about adrenaline, but they did recognize when men were "fighting crazy" or performing almost inhuman feats on the battlefield. ${ }^{40}$ In the fighting around Petersburg, William Phillips was astonished by his response to battle: "My eyes saw it all, in red and flame, but I could not digest it somehow." ${ }^{41}$ Rushing forward, led by "some other power than myself" he ran straight into the Confederate works. ${ }^{42}$ This "combat narcosis" definitely assisted soldiers in battle, making them almost numb to the events around them, even though they were still witnessing and experiencing them. "During that terrible 4 or 5 hours that we were there I had not a thought of fear or anything like fear," wrote a Massachusetts lieutenant about Malvern Hill, "on the contrary I wanted to rush them hand to hand." ${ }^{23} \mathrm{He}$ had been dreading the battle the entire day before, he admitted, "yet it seemed as the moment came all fear and all excitement passed away and I cared no more than I would in a common hail storm." ${ }^{44} \mathrm{O}$. W. Norton was wounded several times during fighting at Gaines' Mill during the Peninsula Campaign, each wound maddening him even more. Bullets hit his first gun and broke it in two, the scattered ball lodging itself into his chest. Pulling the pieces out he grabbed a second gun from a comrade as that man fell dead; moments later this gun too was hit and a bullet glanced off his canteen into his groin. Pulling the ball out he rushed forward again, grabbing a third gun from a wounded man. After this third gun was also damaged he picked up a fourth one as buckshot hit him in the elbow. ${ }^{45}$ In a letter to a cousin, Norton explained, "My two tent mates were wounded, and after that, they tell me, I acted like a

\footnotetext{
${ }^{40}$ James McPherson, For Cause and Comrades, 39-43.

${ }^{41}$ William Beynon Phillips to Annie, July 4, 1864. SoldierStudies.org, accessed November 11, 2011.

42 Ibid.

${ }^{43}$ Charles H. Brewster, When This Cruel War Is Over: The Civil War Letters of Charles Harvey Brewster, edited by David W. Blight (Amherst: The University of Massachusetts Press, 1992), 345.

${ }^{44}$ Ibid.

${ }^{45}$ Letter from O. W. Norton to "Friends at Home," July 4, 1862. SoldierStudies.org, accessed June 19, 2012.
} 
madman. ${ }^{~} 46$ Once soldiers entered battle, pre-battle anxiety was replaced by a single-minded focus on the tasks at hand, fighting and surviving. ${ }^{47}$

Many soldiers commented on this absence of fear and their concentration only on the immediate tasks of fighting, particularly the loading and firing of their weapons. Writing about Murfreesboro, George Copeland admitted that he had "strange feelings in my heart" after hearing of a failed charge before theirs, but upon advancing through cannon fire, he noted, "our feelings of don't care come over us." ${ }^{\text {"48 }}$ They were ordered forward to a fence and while "the bullets flying around us as thick as hail the idea did not enter my head that I would be shot but would lay down and load my gun then raise up and fire away then load again. ${ }^{.49}$ In a post-war memoir, Leander Stillwell of the $61^{\text {st }}$ Illinois wrote a narrative of the battle of Shiloh. He remarked frequently about the narrow focus of the soldier in battle which made them poor historians since they did not witness or understand the full scope of battle, only their little piece of it. Within this context he notes, "where the common soldier does his duty, all his faculties of mind and body are employed in attending to the details of his own personal part of the work of destruction." ${ }^{50}$ The soldiers attend to the steps of loading and firing his gun with "furious haste and desperate energy" because at any moments they could be dead and "these things require the soldier's close personal attention and make him oblivious to matters transpiring beyond his immediate neighborhood..."51

\footnotetext{
${ }^{46}$ Letter from O. W. Norton to "Cousin L," July 5, 1862. SoldierStudies.org, accessed June 19, 2012.

${ }^{47}$ James M. McPherson, For Cause and Comrades, 39-43; Eric T. Dean, Jr., Shook Over Hell, 54-57.

${ }^{48}$ Letter from George Copeland to Mary Brown, Murfreesboro, January 10, 1863. Ohio Historical Society MSSS 1489 AV Hiram Brown Collection, Box 1, Folder 2, 5-8.

${ }^{49}$ Ibid.

${ }^{50}$ Account of the battle of Shiloh written by Leander Stillwell, April 7, 1862. SoldierStudies.org, accessed June 19, 2012. The SoldierStudies entry states the piece was written in 1862, but it is actually a post-war account published in 1892 written about April 1862 events.

${ }^{51}$ Ibid.
} 
Under the intensified stress of battle, the soldier's mind and body reach the peak of their heightened reactionary states. Non-essential functions shut down, adrenaline and other psychological reactions propel the soldier forward, and the soldier focuses only on the essential functions necessary for survival. In the case of battle, coping with the stress means reacting to the cause, usually enemy soldiers or fire from the enemy lines. Soldiers usually saw firing their weapons, even if they did not know they hit someone, as attacking the source of their stress and this was a coping mechanism in itself. In addition, training and drilling in camp allowed soldiers to fall back on the automatic motions of firing their weapons in the stress of combat. While the mind and body reacted naturally to the stress induced by battle, a soldier focused on the essential actions to ensure survival, which in many cases was fighting and firing their weapons.

The excitement of battle meant that soldiers did not fully register what they saw and experienced in the same way they would have outside that environment. Charles A. Fuller wrote about the battle of Fair Oaks in June 1862, after two companions fell in battle, "I drew up my gun, fired, and then threw myself down behind these two bodies of my friends, loaded my gun, raised up and fired it. This process I repeated until the firing ceased. It was a ghastly barricade, but there was no time for the display of fine feelings." 52 He continued later to state that he believed every person experienced battle based on their individual personalities. In his case, he said "As soon as the first volley was fired all dread and sense of personal danger was gone, the death of the two men, one in front and the other to the right of me produced no shock of (sic) horror I seemed to regard it as the to-be-expected thing, and...I loaded and fired my gun from behind their dead bodies as unconcerned as though it had been in a sham battle." ${ }^{53}$ He expressed

\footnotetext{
${ }^{52}$ Charles A. Fuller, Personal Recollections of the War of 1861. Foreword by Gregory A. Coco. "After Gettysburg" by Herb S. Crumb (Hamilton, NY: Edmonston Publishing, Inc., 1990), 18-19.

${ }^{53}$ Charles A. Fuller, Personal Recollections of the War of 1861, 20.
} 
the relief and change in mentality that first volley of battle brought. Firing their guns and finally reacting to the stress of battle transitioned soldiers from the anxiety of facing battle to the automatic process of withstanding battle. Under the heightened state induced by combat, soldiers reacted differently to situations than they normally would.

The absence of fear in battle helped men fight, but it also heightened the reality of the aftermath when they began to inspect the battlefield. When writing about the battle of Cedar Mountain where he was wounded and lay on the field for more than a day, Private McKnight wrote to his cousin "Never may these eyes of mine see another battlefield. Going into battle is nothing, but visit the field after it is over, it will move hearts of stone." ${ }^{54}$ The trauma of postbattle experiences came at a vulnerable time for soldiers, when they were feeling the physical and psychological collapse after the rush of battle. A man's supply of adrenalin is not unlimited; the end of a battle, or even a lull or retreat in the midst of battle, could cause severe reactions as the body tried to restore its chemical balance. The physical and mental impact of what they had just done finally set in; they realized how tired, dirty, sore, and thirsty they were and could feel depression, low morale, and sudden vulnerability. After the battle of Fair Oaks, his first taste of combat, Charles Fuller wrote "when the firing ceased, I was unaware of the strain and excitement I had been under, until we were ordered to move, when I found that I was in a tremble all over."55

Once the fighting stopped soldiers suddenly realized their exhaustion. Writing to his siblings after the battle of Hanover Court House in 1861, O. W. Norton stated "I cannot tell you how I felt that day. As there was any prospect of a fight I kept my place in the ranks, but, when

\footnotetext{
54 "Copy of letter written to our cousin William Patterson McKnight...during the Civil War" Fairfax Seminary Hospital Virginia, August 24, 1862. Ohio Historical Society, MSSS 1489 AV Hiram Brown Collection, Box 1, Folder 1.

${ }^{55}$ Charles A. Fuller, Personal Recollections of the War of 1861, 20.
} 
we gave up the chase and turned back to where our blankets were left, I fell out to get some water and bathe my head. My tongue was swollen up with the heat and thirst, and I was so faint I could hardly stand." ${ }^{56}$ John Frederic Holahan wrote a detailed account of his participation in the battle of South Mountain which captured the frenzy of combat and the narrowness of the soldier's view of battle. At the end of the day when his regiment had exhausted their ammunition supplies and been relieved by a different brigade in order to fall back, his unit marched back to the point from which they had begun their earlier assault and "the excitement which had upheld us subsiding, we began to realize our exhaustion; but we could eat nothing until we had collected our wounded and made them as comfortable as possible... ${ }^{" 57}$ Immediately after fighting, soldiers needed food, water, and rest to counter the exhaustion experienced as the body reestablished balance and recovered from the heightened stress of combat.

The battlefield itself could be difficult to take in while the soldier was in this tired and vulnerable state after combat. The debris of war was scattered over the ground, which itself bore the marks of battle, but the worst sight was the dead and wounded men. There was no time to give each casualty the attention usually given to the dead in civilian life; instead, remains were buried hastily, sometimes in mass graves, or neglected completely. Remains left uncovered for days before burial crews could reach them were almost unrecognizable as men; soldiers detailed to burial duty had to deal with these scenes in addition to the experience of battle. Men described being unnerved and sickened by the sights seen after battle, wishing they would never have to see them again. Some retained mental images of certain deaths that they could not forget. On the march after Gettysburg, Wilbur Fisk's regiment came across a portion of the battlefield on which

\footnotetext{
${ }^{56}$ Letter from O. W. Norton to "Brother and Sister," June 2, 1861. SoldierStudies.org, accessed June 18, 2012.

${ }^{57}$ Civil War Diary of John Frederic Holahan. Fredericksburg \& Spotsylvania NMP Collections, Volume 92 (emphasis his).
} 
the dead still lay unburied. After describing the swollen and mangled bodies which he called "a sight ghastly beyond description," he admitted "I turned away from the heart-sickening sight, willing to forego gratifying my curiosity rather than dwell upon the horrors of that battle-field. I thought I had become hardened to almost anything, but I cannot say I ever wish to see another sight like that I saw on the battle-field of Gettysburg." 58

Surveying the damage and feeling physically affected by combat, the fears men had pushed aside in the heat of battle returned even more intensely than before. Men who witnessed battlefield casualties, the treatment of remains, and the very real possibility of an anonymous death felt the inevitability of their own demise, and they feared the time they might also become a casualty. The impact of a battle could linger for weeks, months, or years as bodies and evidence of combat remained visible to soldiers marching through or camping on old battlefields. Even more personal, names absent at daily roll call were a constant reminder of the losses they had suffered, and those they might suffer in the future. ${ }^{59}$ Wilbur Fisk wrote after the second battle of Fredericksburg in 1863, "It is difficult to realize in the time of an action, the extreme peril one's life is in. Death there seems of less consequence than anywhere else, one gets so used to it...But when the excitement is over and we go back to camp and see so many comrades whose society was our pleasure, missing, we feel very keenly the loss we have sustained." ${ }^{60}$

This transition from battle-induced heightened state to the post-combat reaction could also happen during battle. Any event that interrupted the mindset of battle could make soldiers keenly aware of their situation, including a retreat, a lull in the fighting, or a wound that turned

\footnotetext{
${ }^{58}$ Emil Rosenblatt and Ruth Rosenblatt, ed., Hard Marching Every Day: The Civil War Letters of Private Wilbur Fisk (Lawrence, KS: University Press of Kansas, 1992), 116.

${ }^{59}$ Gerald F. Linderman, Embattled Courage, 247-248; Eric T. Dean, Jr., Shook Over Hell, 66-68, 74-75; Earl J. Hess, The Union Soldier in Battle, 29, 37-39, 40-43; James M. McPherson, For Cause and Comrades, 42-43.

${ }^{60}$ Emil Rosenblatt and Ruth Rosenblatt, ed., Hard Marching Every Day, 80.
} 
them from combatant to observer. Once the soldier exited the mindset of fighting, the body and mind started to rebalance itself; if that occurred while the battle continued it could be distressful to the soldiers. Charles Fuller wrote after being wounded on the field at Gettysburg, "While lying here entirely helpless, and hearing those vicious bullets singing over my head, I suffered from fear. I had, as most men do, got over the dread of battle after I was once fairly in it, and was enjoying the excitement, but when I was 'done for' as a fighter, and could only lie in that zone of danger, waiting for other bullets to plow into my body, I confess it was with the greatest dread." 61 A retreat during battle not only affected the morale of a unit, it also interrupted a soldier's combat mental state. A retreat made soldiers more aware of the stressors of combat than they had been while fighting, leading to an increase in stress reactions. During a retreat at the battle of Shiloh, Cyrus Boyd learned that his brother, Scott, had "given out" and was lying on the ground in the path of the oncoming Confederates. Not wanting to leave his brother behind, Cyrus found him and tried to get Scott to move, "But he said I should go on as he never could go any farther and that I had better save myself and let him go... No words of mine seemed to have any effect I now took him by the nap of the neck and jerked him upon his feet and told him to come or I should help him with my boot[.]"62 This tactic seemed to rouse Scott because "[a]t this he stood up and I managed to work him along down the ravine and left him to rally on the hill.",63 While hard to tell whether Scott's collapse was mental or physical, the retreat caused him to react strongly to battle and without Cyrus' intervention he would most likely have been killed or taken prisoner.

\footnotetext{
${ }^{61}$ Charles A. Fuller, Personal Recollections of the War of 1861, 95.

${ }^{62}$ Mildred Throne, ed. The Civil War Diary of Cyrus F. Boyd, 32. Emphasis and lack of punctuation in original.

63 Ibid.
} 
Once a soldier exited the heightened physical and mental state experienced in combat, their bodies sought to restore balance and recover. In cases where battles were separated by weeks or months at a time, soldiers had time to rest and cope with the stressors experienced during battle. In situations where armies were under constant pressure - during continuous campaigns, sieges, or the trench-warfare seen in the last period of the war-soldiers were continuously in that heightened physiological state without ample time for the body and mind to recover. Writing from Corinth in May 1862, William T. Shepard described the constant state of readiness in camp and the constant picket firing during the siege, constant "excitement" which he said "wears out the Soldier in body and mind more than any duty he may perform." ${ }^{64}$ If there had to be a fight, he declared, he wished it to come soon "that we may be relieved from this painful anxiety and excitement." ${ }^{65}$ A letter the next day reiterated that the "only trouble is the constant state of excitement and anxiety—Pickets firing all day and night keep our nerves in a very unsettled state." ${ }^{66}$ The siege of Corinth ended on May 30; the following day a relieved Shepherd wrote to his parents " $[\mathrm{w}] \mathrm{e}$ are in hopes of a few days rest... Now that the excitement has passed away—we feel the effects of our unpleasant life for a month past." ${ }^{97}$

This experience led to exhaustion and increased the chances for psychological trauma, a process described by Richard Gabriel as the four stages of gradual combat fatigue. Within the first few days of combat exposure men experience the symptoms of fear-trembling, pounding heart, increased urination or loss of control over bowels/urination, weakness or stiffness, sweating, vomiting, sinking stomach, fear of being alone or fear of enemy fire - and those suffering from acute combat shock become apparent. Once this period ends, soldiers have a new

\footnotetext{
${ }^{64}$ William T. Shepherd, To Rescue My Native Land, 191.

${ }^{65}$ Ibid.

${ }^{66}$ William T. Shepherd, To Rescue My Native Land, 192.

${ }^{67}$ William T. Shepherd, To Rescue My Native Land, 195.
} 
confidence in themselves that will lead to their period of peak performance and low anxiety. After this period of confidence, symptoms of combat exhaustion begin to appear: unending physical exhaustion, intensified fear reactions similar to those experienced within the first period, loss of military skill, over-cautiousness, irritability, inability to sleep, and tremors. This intensifies into feelings of helplessness and hopelessness, failing memory, deteriorating mental processes, and a failure of military skills. If a soldier did not receive treatment at this stage they become incapable of action or face a sudden collapse, usually with a specific traumatic event. ${ }^{68}$

Massachusetts soldier John Perry wrote from a hospital near Petersburg that “[o]ur division is relieved from duty in the front line, where it has fought ever since the campaign commenced...We had been fighting for several days in the most advanced trenches amidst persistent firing from both sides, which, however, did little damage, except prevent all rest and sleep. ${ }^{\prime 99}$ Historian Eric Dean, Jr. reports that one lesson learned from World War II was that "every man has his breaking point" and every man is at risk from environmental stress. Psychiatric staff during that war determined that American troops lost their effectiveness after one hundred days of intermittent exposure to battle and breakdown could be expected after about two hundred total days. These totals might not be accurate for the Civil War, but the underlying psychology appears similar. Men broke down after a period of exposure to battle, some more acutely than others. ${ }^{70}$ William Saxton of the $157^{\text {th }}$ New York Infantry remembered that only seven men of Company $\mathrm{C}$ remained after the battle of Gettysburg. One of these survivors, Leroy Dyer, remained with the unit on the march to Hagerstown, but then got sick and died. Saxton wrote in his diary that the "tremendous strain of those three days of fighting was too much for

\footnotetext{
${ }^{68}$ Richard Gabriel, No More Heroes, 81, 83-88.

${ }^{69}$ Letter from John G. Perry, June 20, 1864. SoldierStudies.org, accessed December 10, 2012.

${ }^{70}$ Earl J. Hess, The Union Soldier in Battle, 67; Eric T. Dean, Jr., Shook Over Hell, 37, 75-76.
} 
him and when it let up he collapsed." ${ }^{71}$ Whether it was days or months, the heightened mental and psychical reactions to stress experienced by soldiers wore down their resiliency.

The conditions and new experiences of the war were unsettling to the volunteer soldier, and they had to deal with them mentally as well as physically. Some men adapted to the war better than others, but all were affected by what they saw, did, and felt. As Argentinean writer José Narosky said, "In war, there are no unwounded soldiers." ${ }^{\text {"72 }}$ Becoming callous to the death and destruction of battle did not mean that soldiers were impervious to its effects. Men had to overcome and reverse their cultural understandings of killing other men to be effective soldiers; for many men it was easier to die than to kill. Men feared dehumanization; feeling like machines could help them withstand battle, but feeling desensitized or disposable was not comfortable. Soldiers came to realize that there were limits to courage, including the fact that it would not protect them from harm. Men realized their own vulnerability and knew their chances of wounds, death, and survival. This acceptance of war's reality could turn a soldier bitter and hopeless, leading some to varying degrees of depression. Soldiers could concentrate on their task during battle, taking advantage of the "hardening" process, but they still witnessed horrible things and reacted to them. ${ }^{73}$

The process of reacting and coping with stress is particular to every individual. Each soldiers will perceive the battlefield in unique ways, partially due to the narrow focus that leads soldier to only see a small fraction of the field around where they are fighting and because each soldier interprets the stress of soldiering differently. Each man in a Civil War battle entered that

\footnotetext{
${ }^{71}$ William Saxton, A Regiment Remembered: The 157 th New York Volunteers: From the Diary of Capt. William Saxton (Cortland County Historical Society, 1996), 85. Army Heritage and Education Center, Carlisle, PA.

72 This quote was the title of a speech Narosky delivered on Veterans Day in 2010.

${ }^{73}$ Drew Gilpin Faust, This Republic of Suffering: Death and the American Civil War (New York: Alfred A. Knopf, 2008): 6, 33-41; Eric T. Dean, Jr., Shook Over Hell, 57; Earl J. Hess, The Union Soldier in Battle, 82-87, 149-153, 156; Gerald F. Linderman, Embattled Courage, 158-159, 245-248; Reid Mitchell, Civil War Soldiers, 58-59.
} 
environment with different fears and different coping styles based on their personality and previous experiences, and each soldier coped with the long-term stresses of warfare using a different combination of coping mechanisms. ${ }^{74}$ Each soldier reacted to their experiences in a unique way, creating as many coping styles and traumatic reactions as there were soldiers. Because of this the mental trauma evidenced by Civil War soldiers occurred along a spectrum from more mild reactions to the extreme decision of suicide.

All soldiers underwent personal changes due to their experiences in the Civil War, but most did not suffer from insanity or decide to commit suicide. The majority of soldiers dealt with reactions to warfare that included fear, stress reactions, trauma particular to one event, nightmares, and long-lasting memories of combat. Writing from Harrison's Landing, VA after the Seven Days Battles, J. B. W. of the $44^{\text {th }}$ New York wrote to a friend, "The falling of trees, the roar of cannon, the explosion of shells, the whistling of bullets, the humming of grape, the ghastly faces of the dead and dying, and the groans of the wounded, all together, combined to make a...picture that time can never efface from my memory." 75 Similarly, after writing a detailed account of his experience at Shiloh, Leander Stillwell wrote in 1892 that "[a]fter the battle of Shiloh, it fell to my lot to play my humble part in several other fierce conflicts of arms, but Shiloh was my maiden fight. It was there I first saw a gun fired in anger, heard the whistle of a bullet, or saw a man die a violent death, and my experiences, thoughts, impressions, and sensations on that bloody Sunday will abide with me as long as I live." ${ }^{, 76}$ While both of these

\footnotetext{
${ }^{74}$ Ben Shalit, The Psychology of Conflict and Combat, 10-13, 17.

${ }^{75}$ R.L. Murray, New Yorkers in the Civil War, A Historic Journal, Volume 3 (Wolcott, NY: Benedum Books, 2004), 56.

${ }^{76}$ Account of the battle of Shiloh written by Leander Stillwell, April 7, 1862. SoldierStudies.org, accessed June 19, 2012.
} 
men withstood the trials of battle, their writing reveals that the experience changed them and stuck with them in the long-term.

In cases where there was no evidence of acute trauma, a soldier's own words often betrayed the fact that his experiences affected him even after "hardening" and having time to acclimate to combat and soldier life. Without an official diagnosis or complete understanding of trauma soldiers used terms such as "the blues," "lonesome," "disheartened," "downhearted," “discouraged," "demoralized," "nervous," "played out," "used up," "anxious," “worn down," "worn out," "depressed," "rattled," “dispirited," “sad," "melancholy,” and "badly blown” to describe what they were feeling. For example, "the blues" could result from the boredom of camp, disease, separation from home, inclement weather, and sometimes battle. ${ }^{77}$ Cavalryman Henry C. Meyer referred to feeling blue several times in his memoirs; after the Second Battle of Manassas he stated "We all felt rather blue over the loss of comrades in the affair the night before, which had seemed to us so needless," and after an engagement at Aldie he said, "That night was rather a blue time for us."78 "Demoralized" and "rattled" were most often used when describing the mental collapse of an individual or group while "badly blown" referred primarily to physical collapse with occasional references to mental issues. ${ }^{79}$

Courage and masculinity were important concepts for Civil War soldiers and for many the biggest fear in battle was being "unmanned" or showing cowardice in front of their comrades ${ }^{80}$ According to Gerald F. Linderman, courage was the central value that drove and sustained Civil War soldiers through their experiences. He argues that courage was rigidly

\footnotetext{
${ }^{77}$ Eric T. Dean, Jr., Shook Over Hell, 115-116.

${ }^{78}$ Henry C. Meyer, Experiences with the New York Cavalry: Under Bayard, Gregg, Kilpatrick, Custer, Raulston \& Newberry 1862-1864 (Oakpost Ltd, 2010): 19, 34.

${ }^{79}$ Eric T. Dean, Jr., Shook Over Hell, 115-116.

${ }^{80} \mathrm{Lt}$. Col. Dave Grossman argues that fear of failing to meet battlefield expectations is a greater cause of mental trauma in soldiers than the fear of injury or death: Dave Grossman, Lt. Col., On Killing, 52-65.
} 
defined for these soldiers as "heroic action undertaken without fear," equating evidence of fear with cowardice. ${ }^{81}$ Yet even soldiers who proved themselves in the face of battle could not escape the physiological and psychological reactions to stress caused by combat. Captain Francis Adams Donaldson admitted in a letter to his brother Jacob in October 1861 that when enemy fire crashed into his regiment during a panicked retreat, "[m]y heart was paralyzed with a dreadful fear and my hair stood on end. Whether it was that I was unable to move, I cannot say, but I stood still in the middle of the road for a moment and looked right into the flaming tongues of fire as they came from the muskets of the unseen hands that fired them." 82 Time did not necessarily reduce the reaction to combat; almost two years later at Chancellorsville in 1863, Donaldson wrote about the fighting on May 3 that "My heart stood still, my blood fairly curdled, my breath came quick and fast, and the cold perspiration broke out all over me." 83

Even if soldiers did not admit their own reactions to stress or fear, many wrote about what they saw in others. While forming into line to assault Marye's Heights at Fredericksburg, Charles Fuller "noticed one of our recruits, a German, who was literally unnerved by fear. His countenance was distorted by terror, and he was shaking in every limb. I think it was impossible for him to march. I do not remember ever seeing him after that time." ${ }^{" 84}$ In some cases, soldiers would write about the breakdown in others in contrast to themselves or place these reactions in the context of cowardice. Writing to his sister in 1862, Edward Miles had a laugh at the expense of his comrade Harvey Weakley. While on picket, they came under fire from the Confederates who poured both musket and artillery fire on their line. While Miles admitted it was "a mighty

\footnotetext{
${ }^{81}$ Gerald F. Linderman, Embattled Courage, 12-21.

82 J. Gregory Acken, Inside the Army of the Potomac: The Civil War Experience of Captain Francis Adams Donaldson (Mechanicsburg, PA: Stackpole Books, 1998), 24-25.

${ }^{83} \mathrm{~J}$. Gregory Acken, Inside the Army of the Potomac, 247.

${ }^{84}$ Charles A. Fuller, Personal Recollections of the War of 1861, 79.
} 
hot time" they had a "great time" with Harvey who "was that bad scared that he couldn't stand hardly. He trembled like a leaf." 85 Similarly, Private Wilbur Fisk recalled New Jersey soldiers pinned down on the field at Second Fredericksburg in 1863, writing "[b]ehind every tree, stump, or whatever would shelter them, they could be seen hiding away from the storm of iron hail and completely paralyzed with terror." 86 His unit tried to rally these soldiers into their ranks, "but such we found to be too demoralized in the knees to be capable of effective service. We approached a deep ditch and, as we expected, it was filled with the trembling cowards, who seemed to be dying a thousand deaths." 87

While soldiers felt the pressure to perform on the battlefield, officers were under additional stress to act bravely and lead their men into battle. Any weakness shown by an officer could lead to the demoralization of his men and the loss of his reputation. Yet, officers also faced the additional stress of leading men to their deaths or giving orders that could lead to additional casualties. ${ }^{88}$ In a reminiscent narrative after the war, Jesse Bowman Young wrote from the perspective of a young boy seeing service in the Civil War, presumably himself since he was very young at the time he served, although he named his protagonist Jack. At the battle of Fredericksburg, "Jack" saw an officer from an adjacent regiment "staggering loosely along in a limp, disjointed sort of way, looking as if his backbone had been taken out of its place and his flesh was trying to get along by itself without the aid of the spinal column." 89 After inquiring as to this officer's ailment, the man replied that he was ill and faint and asked the boy if he had any whiskey to help him. The officer claimed it was "bilious colic" which had troubled him as a child

\footnotetext{
${ }^{85}$ Letter from Edward R. Miles to "Sister," June 25, 1862. SoldierStudies.org, accessed June 19, 2012.

${ }^{86}$ Emil Rosenblatt and Ruth Rosenblatt, ed., Hard Marching Every Day, 78.

${ }^{87}$ Ibid.

${ }^{88}$ Dave Grossman, Lt. Col., On Killing, 89-90, 141-148.

${ }^{89}$ Jesse Bowman Young, What A Boy Saw in the Army: A Story of Sight-Seeing and Adventure in the War for the Union (New York: Hunt \& Eaton, 1894), 148-149.
} 
and "Jack" noted that he was doubled over in pain and sweating profusely. Despite the officer's assertions that he was physically ill and needed a physician, "Jack" "saw the truth in the case; the man was deathly ill — with cowardice. He was not merely shamming; he was in mortal fear, almost dead with fright. He had succumbed to his terrors and was now besides himself with anguish and dread." ${ }^{90}$ While the memoir does not specifically identify this officer, such behavior in battle usually led to a loss in reputation and trust from the unit.

In some cases, soldiers' writings hinted at their own stress reactions in addition to witnessing those around them. Charles Richard Allen's diary for April 6, 1862, the first day of the battle of Shiloh, records his reactions to the battle as well as those of the men around him. His regiment was not one of the first hit by the Confederate assault, but one which saw comrades running from the front in disarray, having been disturbed in their camps, and had to form up a line to meet the Confederates and stop their own men from retreating. While trying to stop the fleeing men, Allen noted that "[s]ome of them are nearly crazed and almost cry as we order them to halt and fall into line."91 Allen drew his pistol on two infantry officers trying to slip by and they protested, "You would not shoot us for trying to escape. Our command has all been wiped out. We either had to be killed or run or taken prisoner." 92 He forced them into the battle line but noted that their faces were pale. Despite standing their ground, the Union line was pushed back on the first day of battle. Allen wrote, "It looked pretty blue that night when we ate our suppers but we all felt satisfied that the Confederate forces had played their last card and that in the morning it would be our time. ${ }^{, 93}$ Even with their optimism, Allen and his comrades felt the weight of the day so keenly that a transport ship coming up the river playing familiar music

\footnotetext{
90 Ibid.

${ }^{91}$ Diary of Charles Richard Allen, April 6, 1862. SoldierStudies.org, accessed June 19, 2012.

92 Ibid.

93 Ibid.
} 
brought up thoughts of home that contrasted with the horror of the day and the soldiers' tiredness. Allen wrote, "I could not help doing what I presume thousands of other soldier done shedding hot scalding tears. That was one of the most trying nights for me I ever experienced in all my life up to that time. The day had seemed like a horrid nightmare." ${ }^{94}$ While Allen takes more time to comment on the fearful and panicked reactions of other soldiers fleeing from the fight, his own comments about feeling "blue" and crying at the sounds of music because of the "horrid nightmare" he witnessed that day, betray the impact those traumatic experiences had on him.

Soldiers also hinted at the long-term effects of some of their battlefield experiences. While they relied on the heightened combat state and the narrow focus of loading and firing their weapons as noted above during battle, the sights, sounds, and experiences of those battles often came back in the form of nightmares or other flashbacks. Remembering the experience in these forms is a basic symptom of a traumatic experience, included in the diagnosis of Post-Traumatic Stress Disorder. William T. Shepard was particularly candid in the letters to his family, describing in detail his experiences in the war and his reactions to them. After his first engagements at the battles of Frederickstown and Belmont in 1861 he wrote to his father that now that the excitement of battle had passed, he had the opportunity to reflect on his experiences. Expressing a sense of astonishment that he had survived the conflict, he wrote, "As the booming of the artillery and the roar of musketry comes to our ears - and we see with our minds eye the dead and dying on that field-We wonder more than ever that we are yet alive and unharmed." 95 Continuing his reflections, he admitted to his father that although it had been a week since the engagement, "yet the sound of a musket makes me shudder — and the discharge of a cannon-

\footnotetext{
${ }^{94}$ Ibid.

${ }^{95}$ William T. Shepherd, To Rescue My Native Land, 105 (emphasis his).
} 
seems unfinished, without the whizzing of a shell immediately after-My rest at night is often troubled with a visionary battle—sometimes victorious and at others utterly defeated—."96 Another soldier, James O. Churchill wrote that he would be haunted by a recurring nightmare about his Civil War service: "I would be in battle and charge to the mouth of a cannon, when it would fire and I would be blown to pieces. ${ }^{" 97}$ In these cases, soldiers revealed the lasting effects of combat and the stress of soldiering.

For some men, the pressure of soldiering was enough to convince them to harm themselves in order to escape the stress. William Mackenzie of the $15^{\text {th }}$ New Jersey wrote to the Hunterson Gazette in January 1863 that several strange accidents had occurred in camp in which soldiers' hands were injured. He noted a member of his company who almost completely cut the forefinger on his right hand off while chopping wood and two members of a different company who were wounded on picket duty after one of their guns discharged accidently. In both cases the soldiers had to have parts of their right hands amputated. Mackenzie surmised that these "accidents" were in fact done on purpose with the goal being a discharge, and stated that these "cowards should have their heads shaved and be drummed out of the service." 98 Along with his story about the terrorized officer, Jesse Bowman Young also wrote about a second officer whom "Jack" witnessed hidden away behind an outbuilding. Describing the man as "[w]ith pallid face, and his body trembling and shaking as if with the palsy" "Jack" watched as the officer hastily looked around to see if anyone saw him, took his pistol and shot himself in the arm to make a

\footnotetext{
${ }^{96}$ Ibid.

${ }^{97}$ James O. Churchill, Brevet Lieut. Col., "Wounded at Fort Donelson," in War Papers and Personal Reminiscences, 1861-1865, Read before the Commandery of the State of Missouri, Military Order of the Loyal Legion of the United States, Volume I. (St. Louis: Becktold \& Co., 1892), 164.

${ }^{98}$ Letter from William Mackenzie (Co. G, 15NJ) to Hunterson Gazette, Camp near White Oak Church, VA, January

9, 1863. Fredericksburg \& Spotsylvania NMP Collection, New Jersey Manuscripts USAMH1, Volume 109.
} 
flesh wound, and then headed for the rear "holding his arm and making a great ado about the bullet that had gone through it!"99

Some soldiers reacted more strongly to the experience of combat than others. One example is the case of John Bumgardner of the $26^{\text {th }}$ Indiana Light Artillery, who was knocked down by the concussion of an exploding shell. Recovering himself he was shaken and pale and became morose and sullen for several weeks, in addition to suffering fits of trembling. He talked about fighting and yelled about the enemy approaching when there was no combat present; he was finally sent to an insane asylum in Kentucky. ${ }^{100}$ In another case, Captain Francis A. Donaldson remembered a Private Hyatt in his company who was kneeling on his knapsack tightening the blanket roll strap while they were all crouching to avoid incoming artillery shells. According to Donaldson's letter to his brother, "a solid shot dashed into the ground beneath [Hyatt], coming out again beyond him and taking the heel of one of his shoes. The concussion lifted him up at least a foot, but he was not hurt apparently, only paralyzed both in body \& speech...I had him taken to the rear on a stretcher, he was unable to walk."101 The case of Albert Frank, fighting around Bermuda Hundred near Richmond, VA, is more severe. While offering the man next to him a drink from the canteen around his neck, the other soldier was decapitated by a shell. That night Frank began to act strangely, running over the breastworks toward the enemy where his fellow soldiers found him huddled, and making shell sounds followed by saying "Frank is killed." His comrades had to restrain him and eventually sent him to a hospital in Washington under a declaration of insanity. ${ }^{102}$

\footnotetext{
99 Jesse Bowman Young, What A Boy Saw in the Army, 147-148.

${ }^{100}$ Eric T. Dean, Jr., Shook Over Hell, 66.

${ }^{101}$ J. Gregory Acken, Inside the Army of the Potomac, 407.

${ }^{102}$ Eric T. Dean, Jr., Shook Over Hell, 42, 65-66.
} 
Extended campaigns wore down soldiers' resilience and strength much faster than the shorter campaigns of the early war period. When Lorenzo G. Babcock of the $125^{\text {th }}$ New York Infantry killed himself with a bullet to the chest near Todd's Tavern in May 1864, his comrades pointed to the hardship and exposures of the Overland Campaign as the cause. Comrades testifying for his mother's pension claim remembered that their regiment had already been through a few days of hard fighting and marching at the Wilderness and that Babcock had lost his haversack and canteen in the march. In his affidavit, H. Sykes remembered that "[i]n the Wilderness the strain on our minds and bodies had been severe" and that Babcock had tried to shoot a comrade the night before his death, apparently believing he was the enemy. ${ }^{103}$ Washington Akin testified that he had seen Babcock about fifteen minutes before the soldier killed himself, stating that he "was covered with dirt, and looked as if he had been in the thickest of the fray. He said to me that the rebels would soon surround us, and seemed to have that constantly on his mind, when there was no indication of any thing of the kind." 104 Comrades believed that Babcock's jumpy and apprehensive behavior on May 8 and 9, 1864, and resulting suicide, was a result of the continuous fighting and stress of the campaign. ${ }^{105}$

Wartime experiences often led to long-term physical and mental conditions that affected veterans for years after the fighting ended. Robert $G$. Thompson of the $32^{\text {nd }}$ Ohio Infantry was acting as a hospital ward master when he was admitted for a short period of time in 1863 at the Government Hospital for the Insane for "Acute Nostalgic Melancholia with suicidal tendencies."106 While Robert and his former first sergeant both testified for the pension claim

\footnotetext{
${ }^{103}$ Pension of Mary Babcock (mother to Lorenzo Babcock) application 197327, certificate 283941. National Archives, Washington, D.C.

104 Ibid.

105 Ibid.

${ }^{106}$ Robert G. Thompson, pension application 371440 and certificate 339374, widow pension application 1018969. National Archives, Washington, D.C.; Letter from Robert Thompson to William Godding, May 24, 1886. Records of St. Elizabeth's Hospital, record group 418, case \#1107. National Archives, Washington, D.C.
} 
that he was no longer insane-Robert took great care in his pension claim to establish that he was not seeking a pension for insanity-Robert's file shows the strain of long-term coping with his wartime experiences. He complained of headaches, sleeplessness, nervousness, and "an indefinable foreboding of some terrible evil." ${ }^{107}$ When writing to the superintendent of the GHI in June 1886 he revealed, "No pen can describe what I have suffered in body and mind the last 23 years nearly haunted almost hourly with a fear of a return of those terrible scenes through which I have passed in the years gone by utter inability to obtain sleep in the after part of the night, and then complete exhaustion through the day, with nervous excitement..., almost to distraction." 108 Despite his history, Robert was adamant that he was not currently insane, only suffering from the long-term consequences of this period of wartime insanity. His first sergeant testified in support of Robert's case that "although the man is not now insane, I believe from the condition in which I found him in the fall of 1863, that he had previously endured some terrible suffering both mentally and physically, and that it left a lasting effect."109

Beyond the battlefield and camp, prisoners of war were a group that faced particular traumas, both mentally and physically. Early in the war, prisoners were usually kept only for a few days before being paroled. Soldiers, although enemies, felt a certain bond through their shared experience, so prisoners were usually treated well by front-line soldiers. Later in the war, however, the system collapsed over disputes about how to deal with African-American prisoners. Prisoner exchanges halted and led to extended situations in prisons such as Andersonville, Georgia and Elmira, New York. While POWs were still treated civilly on the frontlines, they faced harsher treatment by the soldiers controlling prison camps. In the unfortunate

\footnotetext{
${ }^{107}$ Robert G. Thompson, pension application 371440 and certificate 339374, widow pension application 1018969. National Archives, Washington, D.C.

108 Ibid.

${ }^{109}$ Ibid.
} 
circumstances of these camps, prisoners had inadequate shelter, clothing, food, and little stimulation. ${ }^{110}$

The foundations soldiers clutched to manage their wartime experiences completely broke down in the environment of prisoner camps, sometimes even breaking the bonds of camaraderie so crucial to surviving camp life and battle. Deprivation, monotony, cruelty, disease, and death forced some prisoners to sink into apathy and face long-standing psychological and physical issues and others to consider or commit suicide. In the case of John McGraw of the $43^{\text {rd }} \mathrm{New}$ York Infantry, the soldier was captured twice during the war. According to his pension file he was captured first at Second Fredericksburg in May 1863, but almost immediately paroled. He was captured again at Bristow Station or Warrensburg in October 1863 and it was then that he was confined in Richmond for several months. After his parole in 1864 he entered the Government Hospital for the Insane where the records show he "was under treatment for acute mania" from January to June 1865 for insanity of the last three months, "the ascribed cause was debility, the result of hardships endured while confined in Libby Prison." ${ }^{111}$ An Ohioan soldier admitted to Longview State hospital in 1868 suffered from hallucinations and violent spells. His records note that "it appears this young man was a U.S. Soldier and was confined for a long period at Andersonville prison...The Supposed Exciting Cause...is his experience of Andersonville." 112

\footnotetext{
${ }^{110}$ Charles W. Sanders, Jr., While in the Hands of the Enemy: Military Prisons of the Civil War (Baton Rouge: Louisiana State University Press, 2005), 82-163; Gerald Linderman, Embattled Courage, 236-239; Eric T. Dean, Jr., Shook Over Hell, 81-83. See also Roger Pickenpaugh, Captives in Blue: The Civil War Prisons of the Confederacy (Tuscaloosa: The University of Alabama Press, 2013).

${ }^{111}$ John McGraw, widow pension application 334028. National Archives, Washington, D.C.; Annual Report of the Adjutant-General of the State of New York. For the Year 1900. Registers of the Thirty-ninth, Fortieth, Forty-first, Forty-second and Forty-third Regiments of Infantry. Transmitted to the Legislature January 9, 1901 (Albany: James B. Lyon, State Printer, 1901), 1256. dmna.ny.gov/historic/reghist/civil/rosters/Infantry/43rd_Infantry_CW_Roster.pdf (February 2, 2015). ${ }_{112}$ Ohio Historical Society, Longview State Hospital, Case History of Male and Female Patients, 1863-1918 (call \#: State Archives Series 541) (BV4389), 173.
} 
Francis Amasa Walker wrote of his time as a prisoner of war that he suffered "a period of nervous horror such as I had never before and have never since experienced, and memories of which have always made it perfectly clear how one can be driven on, unwilling and vainly resisting, to suicide. I remember watching the bars at my window and wondering whether I should hang myself from them." 113 Walker resisted such temptation, but others could not, despite the restrictions of available materials in the prison camp. One cavalryman tried to cut his throat with a dull knife and another man used his suspenders as a noose. The "dead line" was an apparently popular form of committing suicide; this was a perimeter set up at many prison camps, either an imaginary line or marked in ways such as the "narrow strip of board nailed on uprights running about the enclosure" described by one Andersonville inmate. This marked the point prisoners could not pass without being shot by the guards. "One step over," wrote Austin Carr in 1864, "and the penalty is death." 114 For prisoners with no other means of ending their lives, this was an opportunity to have others do it for them. There are reports of several men purposely stepping over that line, including one whose mission failed when the guard refused to shoot him. There is no question that these men wanted death; one soldier stepped over the line and challenged the sentry to shoot him, after two failed shots he yelled at the guard to do his duty and the third shot hit him in the head, killing him instantly. ${ }^{115}$

Suicide, such as these prisoner of war cases, was the most drastic reaction along this spectrum of trauma, but it was also probably the least common. ${ }^{116}$ In total, statistician Thomas F.

\footnotetext{
113 Gerald Linderman, Embattled Courage, 260.

114 Austin Carr diary (excerpted transcript), US Army Heritage and Education Center, Carlisle, PA, The Harrisburg Civil War Round Table Collection, Box 7.

115 William Marvel, Andersonville: The Last Depot (Chapel Hill: The University of North Carolina Press, 1994), 157, 190; Eric T. Dean, Jr., Shook Over Hell, 81, 83; Alfred Lyth, “The Andersonville Diary of Private Alfred Lyth,” Niagra frontier 8, no. 1 (1961): 22; Gerald Linderman, Embattled Courage, 257-261.

${ }^{116}$ For more on the topic of suicide in the Union Army, see Kathleen Anneliese Logothetis, "A Question of Life or Death: Suicide and Survival in the Union Army,” M.A. Thesis, West Virginia University, 2012.
} 
Barr identified 391 suicides among Union casualties. ${ }^{117}$ This number represents less than one percent of the Union casualties during the Civil War, far different than the modern military where suicide has, at times, been the second leading cause of death for service members. ${ }^{118}$ Because suicide is often a very personal action in which the deceased do not leave many clues behind as to their motivations, it can be very hard to pinpoint the direct cause of the suicide; in the case of Civil War suicides there is the added complication of 150 years and a nineteenthcentury culture that differed from modern society on issues of mental health.

While some suicides have no recorded cause, others can be connected directly to the trauma of war. Told that he only had a few hours to live due to mortal wounds received at Antietam, a sergeant shot himself with a revolver, perhaps not willing to suffer the pain with no hope of recovery. Another wounded soldier did not even make it off the battlefield before he took his own life. ${ }^{119}$ At Fredericksburg, Thomas H. Evans of the $12^{\text {th }}$ US Regulars reported passing over the battlefield on Marye's Heights immediately after the engagement, hearing a shot, and then finding a body with a rifle lying across it, powder burns on the clothing, and the head shattered from the chin upwards. Evans wrote: "He had probably mistaken our approach for a body of the enemy, and in his agony and horror of becoming a wounded prisoner, had blown out the remains of his life by his own act." 120

\footnotetext{
117 Thomas F. Barr, "Cost and Compensations of the War," in Military Essays and Recollections: papers read before the Commandery of the State of Illinois, Military Order of the Loyal Legion of the United States, Volume I (Chicago: A.C. McClurg and Company, 1891): 521.

${ }^{118}$ Using Barr's statistics, 391 suicides out of his calculated 359,528 total casualties puts the suicide rate for the Union army as $0.108 \%$; Another set of statistics created by Frederick Phisterer counts 302 suicides out of 304,369 total Union dead, a rate of $0.099 \%$ [Frederick Phisterer, Statistical Record of the Armies of the United States (New York: Charles Scribner's Sons, 1883): 69-70]; Craig J. Bryan, "The Clinical Utility of a Brief Measure of Perceived Burdonsomeness and Thwarted Belongingess for the Detection of Suicidal Military Personnel," Journal of Clinical Psychology 67, no. 10 (2011): 981.

${ }^{119}$ Earl J. Hess, The Union Soldier in Battle, 90.

${ }^{120}$ Thomas H. Evans, "The Cries of the Wounded were Piercing and Horrible," Civil War Times Illustrated 7 (July 1968): 33.
} 
At the battle of the Wilderness, a continuous campaign combined with the wooded terrain of the area created new stress for soldiers. Fighting in the woods created confusion during the battle, but it also brought the danger of fire which prompted veteran Frank Wilkeson to recount scenes from the battle where the wounded lay on the battlefield haunted by the fear that fire would sweep through the woods as it had the previous year. Unable to move, "their hearts wellnigh ceased to beat when they thought they detected the smell of burning wood in the air. The bare prospect of fire running through the woods where they lay helpless, unnerved the most courageous of men, and made them call aloud for help." ${ }^{121}$ In this dire situation, Wilkeson remembered that "I saw many wounded soldiers in the Wilderness who hung on to their rifles, and whose intention was clearly stamped on their pallid faces. I saw one man, both of whose legs were broken, lying on the ground with his cocked rifle by his side and his ramrod in his hand, and his eyes set on the front. I knew he meant to kill himself in case of fire- knew it as surely as though I could read his thoughts." ${ }^{122}$ For two days the armies struggled at the Wilderness, resulting in thirty-thousand casualties. Fires did indeed rage through the woods and claimed the lives of many wounded soldiers who could not get away. These three examples are easily connected to physical wounds or the immediate stressors of combat; far more examples of suicide occurred away from the battlefield, probably due to the long-term stresses of soldiering and being away from home.

Beyond psychological cases of trauma and insanity, some soldiers did experience purely physical mental impairments. Injuries to the head resulted in cases of mental debility and these were easier for physicians to diagnose. Writing about the battle of Fair Oaks in June 1862,

\footnotetext{
${ }^{121}$ Frank Wilkeson, Recollections of a Private Soldier in the Army of the Potomac (New York and London: G.P. Putnam's Sons, 1887): 66-67.

${ }^{122}$ Ibid.
} 
Charles Fuller remembered a shocking sight from the battle when comrade Sanford Brooks was shot through the head. Fuller reported that the bullet entered the head behind the eyes in a manner that did not instantly kill Brooks but threw the eyes out of their sockets and destroyed the man's mental reason. "The blow did not fell him to the ground," Fuller remembered, "he stood upright with his gun clinched in one hand, his sightless eyes bulged out of his head, and he staggered about bereft of reason. He lived for a day or two, talking constantly of camp life, and the things that were on his mind before this fatal shot." 123

Other physical injuries outside of battle also caused cases of insanity. When Samuel Wicks returned home from the service in 1864 his brother noticed that he was forgetful and acted differently than usual. Wicks pointed to the explosion of a hundred-pound Parrott Gun before Fort Wagner as the cause of his head and back trouble and forgetfulness. A deposition by Matthew Lewis of Wicks' company stated that the claimant had been hit by a fragment of the cannon and sent to the hospital; Wicks ended up at the Government Hospital for the Insane (GHI) where he was discharged from the service. ${ }^{124}$ Joseph Helm applied for a pension for an injury caused by a cannon wheel striking his head during the battle of Spotsylvania on May 12, 1864 which caused "vertigo and severe chronic headaches, lasting 2-3 months at a time, causing often vomiting and disabling him to endure exposure to sunrays." ${ }^{125}$ New York cavalryman Terence Kelly fell from his horse late in the war while on scout and injured his head, leading to insanity a few weeks later. Surgeon certificates in the 1870 s note a depression on Kelly's head

\footnotetext{
${ }^{123}$ Charles A. Fuller, Personal Recollections of the War of 1861, 18-19.

${ }^{124}$ Samuel H. Wicks, pension application 316392 and certificate 414221. National Archives, Washington, D.C.; Annual Report of the Adjutant-General of the State of New York for the Year 1904. Registers of the One Hundred and Fortieth, One Hundred and Forty-First, One Hundred and Forty-Second, One Hundred and Forty-Third, One Hundred and Forty-Fourth, One Hundred and Forty-Fifth and One Hundred and Forty-Sixth Regiments of Infantry. Transmitted to the Legislature January, 1905 (Albany: Brandow Printing Company, State Legislative Printers, 1905), 894. dmna.ny.gov/historic/reghist/civil/rosters/Infantry/144th_Infantry_CW_Roster.pdf (February 25, 2015). 125 Joseph Helm, pension application 1036904. National Archives, Washington, D.C.
} 
from the fall, or a reported sabre wound, and that the soldier had spent time in an asylum and at home, completely enfeebled and in need of care. ${ }^{126}$ John G. Wicks complained of hernia and chronic diarrhea in his pension claim, but also suffered a period of insanity during the war caused by the collapse of a bunk he was sleeping under in camp at Elmira that injured his eye and sent him to the GHI in $1864 .{ }^{127}$

There is vast anecdotal evidence that Civil War soldiers experienced the traumatic events of soldiering in similar physical and psychological ways as more recent soldiers. When soldiers described their reactions to battle and the experience of soldiering, or commented on a comrade's reactions, they revealed both the brutal and exhausting nature of the Civil War and the soldier's attempts to understand and rationalize the events happening around them. The notion that battle and war is horrifying and weighs on the senses of those fighting is not a new one, and this brief examination is enough to suggest the existence of mental trauma during the Civil War. Soldiers who felt the weight of the war too keenly, however, and experienced mental difficulties or breakdown faced a society where the idea of mental trauma was not widely understood or accepted. The medical and cultural understandings of the nineteenth century did not allow for soldiers to break down mentally under the pressure of war. By the mid-nineteenth century, treatment of insanity within established asylums under a new field of psychiatry allowed for some recognition of mental illness, but, for the most part, psychiatrists and military officials did not connect wartime experiences to cases of soldier insanity. Instead, physicians and asylums focused on the physical and moral causes of insanity that fit the cultural expectations and medical knowledge of the nineteenth century. For soldiers facing the traumatizing experiences of

\footnotetext{
126 Terence Kelly, pension application 161899, certificate 112953. National Archives, Washington, D.C.

127 John Wicks, pension certificate 110216. National Archives, Washington, D.C.
} 
the Civil War, the culture and social norms of nineteenth century America proved resistant to accepting mental trauma as a legitimate ailment. 


\section{Chapter 2:}

"The Supposed Exciting Cause is the War...The Disease is Probably Hereditary":

\section{Official Definitions and Treatments of Insanity and Mental Illness}

In his report on the Michigan Asylum for the Insane for the year 1861-1862,

Superintendent E. H. Van Deusen stated in regards to questions about the Civil War causing an increased number of insane cases that "[t]here seems to be nothing, either in the nature of the struggle in which so many of the citizens of our State are now personally engaged, or in the circumstances under which they left their homes, calculated to induce an unhealthy physical condition." While the call to arms was abrupt, Van Deusen argued that the soldiers responded with a prompt sense of duty to protect their nation and its institutions. This spirit of patriotism protected these men from mental troubles and consequently "[i]n the transition, therefore, from civil to military life, we detect nothing calculated to induce or develop mental disease."2 However, while there was nothing concerning in the physical environment, Van Deusen warned of the immoral influences of camp that might lead to the development of insanity. ${ }^{3}$ Similarly, Charles H. Nichols, superintendent of the Government Hospital for the Insane (GHI) wrote in his report for 1862-1863 that the war was not a cause of insanity but that "[t]he existence of more or less home-sickness among the national troops - perhaps the most pardonable weakness which a citizen soldier in the field can display — has been rendered evident by the character of the morbid mental manifestations exhibited by several of our army patients. ${ }^{\circ 4}$ Both of these asylum

\footnotetext{
${ }^{1}$ Superintendent's Report, E. H. Van Deusen. Biennial Report of the Board of Trustees of the Michigan Asylum for the Insane, For the Years 1861-1862 (Lansing: John A. Jeer \& Co., Printers to the State, 1862). Falk Library, University of Pittsburg Health Sciences Library, Collection Ms 9, Insane Hospital Reports, Volume I, page 24-27.

${ }^{2}$ Ibid.

${ }^{3}$ Ibid.

${ }^{4}$ Reports of the Board of Visitors and the Superintendent of Construction of the Government Hospital for the Insane, for the year 1862-1863 (Washington: Gideon \& Pearson, Printers, 1864), 18-23. Reports of the Government Hospital for the Insane, Vol. 1, 1855-1874. Office of the Chief Clerk, Department of the Interior. Record Group 48, Entry 298, Box 6. National Archives, College Park.
} 
superintendents portrayed wartime insanity among soldiers as a result of moral weaknesses, not the physical environment of the war.

And yet, as examined in chapter one, soldiers did become insane or exhibit symptoms of mental difficulty during their time in the army. In a few, rare instances the records hint that battle and soldiering was the cause of insanity. In the case of a young soldier who enlisted as a teenager and was admitted into Dixmont State Hospital in late 1865, the admitting physician labeled his condition as epilepsy with the supposed cause "fright at battle of Cold \{last word illegible\}." In the wartime pension application of William Kenney, the captain of his company in the $82^{\text {nd }}$ New York Infantry testified that "during the Peninsula Campaign in the State of Virginia he the said William Kenney became insane from the excitement incident to the battles and the severity of the service." ${ }^{\prime 6}$ For a $71^{\text {st }}$ Ohio soldier, the initial asylum admission in 1864 listed the cause of his insanity as “exposure,” but a post-war surgeon's certificate for his pension claim states, "From what we can gather from him and his history we believe that his insanity was caused from fright at the battles of Pittsburgh Landing + Fort Donaldson."7 However, these examples represent a distinct minority among the cases of soldiers, because they made a connection between wartime experiences and mental affliction.

When soldiers exhibited symptoms along the spectrum of trauma and insanity, they forced the medical and military community to respond with treatments and policies to handle these men. Due to the understanding medical professionals held at the time about both mental and physical illness, official medical treatments were limited and often focused on perceived

\footnotetext{
${ }^{5}$ Pennsylvania State Archives, RG-23 Records of the Department of Public Welfare, Dixmont State Hospital, Patient History Books, 1859-1950 ( $2^{\text {nd }}$ Roll, 1863-1866) (Roll 19) Volume II on Roll 6/1865-8/1866.

${ }^{6}$ William Kenney, pension application 17066. National Archives, Washington, D.C.

${ }^{7}$ Pension application 185109 and certificate 140569, widow pension application 323055 and certificate 218049. National Archives, Washington, D.C.; Dayton State Hospital, Register of Male and Female Patients, 1855-1902. Ohio Historical Society, call \#: State Archives Series 153, BV8897, page 25.
} 
physical or moral causes instead of connecting insanity to the experience of warfare. In addition, the Union Army understood insanity to a degree and had an asylum system to support insane soldiers, but they also had to balance the necessity of keeping soldiers in the front lines.

Consequently, soldiers exhibiting symptoms of trauma had some access to official treatment options, but many did not benefit from the system in place.

Concepts of insanity were not new in the 1860s; however, the Civil War occurred during a transition in the understandings of mental illness. In the seventeenth and eighteenth centuries, Americans saw the mentally ill as an economic and social issue. The family was largely responsible for caring for a mentally ill relative for there were no institutions to care for them. If the family could not economically care for them or they were a danger to society, the insane went into jails or almshouses which housed those in society who could not care for themselves (the young, elderly, poor, or infirm) under poor laws or public charity. Without formal institutions or methods of treatment, the insane were largely contained and controlled, sometimes in poor conditions, or treated based upon older, traditional forms of medicine. ${ }^{8}$

In the nineteenth century mental illness was no longer an economic or social problem, but a treatable medical issue. The medical field as a whole was changing to be more scientific, and the treatment of the insane moved from familial homes to institutionalized insane asylums. A period of philanthropy and social activism when reformers argued that the problems of humanity could be diminished or fixed led to the establishment of both general and mental hospitals. No longer would the mentally ill be locked away to keep them from society, instead they were institutionalized in the hopes that new theory and treatment might cure them and restore them to productive members of society. At first insane asylums were privately or corporately funded,

\footnotetext{
${ }^{8}$ Gerald N. Grob, Mental Institutions in America: Social Policy to 1875 (New York: The Free Press, 1973), 1-34.
} 
part of the philanthropic trend of the antebellum period, but it soon became evident that private supporters could not fund care for the number of patients who needed placement in an asylum. This led to state and locally governed institutions, still concerned with problems of poverty and operating in the context of welfare and dependency. ${ }^{9}$

Doctors in nineteenth-century asylums balanced a transition from colonial medicine to new understandings of medicine. Traditional medicine followed the principles of the four humours, known as "Galenic" after the Roman Galen of Pergamon and based on earlier medicine from Greece. Based on the idea that there were four natural elements - air, water, earth, and fire- - early Greek doctors, such as Hippocrates, also categorized the human body into four elements: blood, phlegm, yellow bile, and black bile. Well into the nineteenth century, doctors diagnosed any illness as an imbalance of the humours and treated patients with remedies meant to purge the body of "bad" or excessive fluids. In mental institutions the use of tonics, drugs, hot and cold treatments, and special diets to strengthen the body in order to heal the mind continued the traditions of earlier Galenic medicine. ${ }^{10}$ In addition, doctors tried to categorize their patients using Galen's categories of temperaments which translated combinations of the humours into physical and psychological qualities to classify "types" of people. While medicine started to move away from its Galenic roots during the nineteenth century, these ideas and treatments still had a strong hold over the understandings and treatment of the mentally ill.

On the other hand, antebellum doctors found that many of the traditional methods of treatment produced no results in the patients admitted into the new insane asylums. Instead, they turned to "moral treatment" as a new regime to treat and cure America's insane. In the nineteenth

\footnotetext{
${ }^{9}$ Gerald Grob, Mental Institutions in America, 1-2, 35-39, 84-85.

${ }^{10}$ Noga Arikha, Passions and Tempers: A History of the Humours (New York: HarperCollins Publishers, 2007), 329; Gerald Grob, Mental Institutions in America, 165-170.
} 
century, people believed in "environmental determinism" and under this idea doctors believed that mental illness was curable with a correctly managed environment. While there were various theories about the cause of mental illness-whether it was due to the impairment of sensory organs sending false messages to the brain or a physical disease of the brain itself - there was a strong belief that mental illness evidenced some violation of the laws of nature. The psychiatry of the time was heavily influenced by cultural and moral theory. Beginning in the 1830 s the idea of "moral insanity" was defined as a "morbid perversion of the natural feelings, affections, inclinations, temper, habits, moral disposition, and natural impulses..."11 As historian Michael Barton states the "times demanded so much mortality that immortality-losing control of the impulses - had to be called insanity. Every man had to have a 'moral sense' or else he was simply not a normal creature." 12 In this sense, an individual could cause their own insanity by ignoring the rules of human behavior, and could be cured back to health through the restoration of a proper environment. Some cases of mental illness resulted from physical injuries to the head and brain (which doctors did not have the knowledge to properly treat), but a larger proportion were considered "moral cases," those which could be fixed through proper moral treatment. In these cases, institutionalization was crucial in order to take a person away from a "bad" environment, and place them in a "good" one. ${ }^{13}$

Superintendents carefully structured the environment within mental institutions to provide the basis for moral treatment, even carefully considering architecture and landscaping in

\footnotetext{
${ }^{11}$ Michael Barton, Goodmen: The Character of Civil War Soldiers (University Park: Pennsylvania State University Press, 1981), 72-73.

${ }^{12}$ Michael Barton, Goodmen, 73.

${ }^{13}$ Carla Yanni, The Architecture of Madness: Insane Asylums in the United States (Minneapolis: University of Minnesota Press, 2007), 8; Gerald Grob, Mental Institutions in America, 42-51, 152-156, 166; Francis J. Braceland, The Institute of Living: The Hartford Retreat, 1822-1972 (Hartford, CT: The Institute of Living, 1972), 30-33.
} 
the development of insane asylums. ${ }^{14}$ Under a design created by Thomas Kirkbride, the first hospitals were small establishments to house at most 250 patients at a time, carefully constructed to provide the ideal environment for successful treatment. For example, architects designed the Government Hospital for the Insane (GHI), later known as St. Elizabeth's Hospital, as an imposing red brick Gothic fortress with outer wings gradually tapering in height from the central tower. ${ }^{15}$ While state and local governments ran most mental hospitals in the country, the Government Hospital for the Insane was the first and only federally funded asylum. Founded in 1855, the asylum was created to treat members of the United States armed forces, with the ability to care for mentally ill residents of the District of Columbia if there was room available. ${ }^{16}$ The design of the GHI placed the most troublesome patients the farthest from the central common rooms used by patients and visitors, and enforced the role of the asylum superintendent as the dominant figure by placing his offices in the tall, central building. Patients could use the dining halls and dayrooms in each wing during the day and then return to their bedrooms at night, with physical restraints rarely used to limit their movement. Within these carefully designed buildings, doctors and staff treated patients under the new methods of "moral treatment," what the founders described as "the most humane care and enlightened curative treatment of the

\footnotetext{
${ }^{14}$ For more on the use of architecture and landscaping in the development of nineteenth century asylums see Carla Yanni, The Architecture of Madness; Francis McMillen, "Ministering to a Mind Diseased: Landscape, Architecture and Moral Treatment at St. Elizabeth's Hospital, 1852-1905," MA Thesis, University of Virginia, 2008; John Curwen, comp., History of the Association of Medical Superintendents of American Institutions for the Insane, From 1844 to 1874, Inclusive: with a list of the different hospitals for the insane, and the names and dates of appointment and resignation of the medical superintendents. Compiled from the records of the Association by John Curwen, M.D., Secretary of the Association (1875); Francis J. Braceland, The Institute of Living, 18-19.

15 The Government Hospital for the Insane was also named St. Elizabeth's Hospital by sane soldiers recuperating in the military hospital there; the name was officially changed to St. Elizabeth's in 1916 and it still retains that name. ${ }^{16}$ Carla Yanni, The Architecture of Madness, 66-71; By-Laws of the Government Hospital for the Insane, etc. September 1855 (Washington: G. S. Gideon, Printer, 1855), 21-23. Reports of the Government Hospital for the Insane, Vol. 1, 1855-1874. Office of the Chief Clerk, Department of the Interior. Record Group 48, Entry 298, Box 6. National Archives, College Park; Nancy Tomes, The Art of Asylum-Keeping: Thomas Story Kirkbride and the Origins of American Psychiatry (Philadelphia: University of Pennsylvania Press, 1994), 193-222.
} 
insane..."17 While there were still elements of medical care that reflected colonial medicine, the main emphasis remained on moral treatments. Staff members showed kindness and patience towards the patients, using punishment or restraint only in the case of frequent misbehavior. Even if doctors punished patients, it was not violent or cruel; instead the focus was on using occupational therapy, religion, and amusements to create a positive environment in which to reeducate the patient to proper behavior and mental state. As historian Gerald Grob states, "the goal was the inculcation, through habit and understanding, of desirable moral traits and values. The ideal hospital, in other words, was modeled along the lines of a closely knit and cohesive family." 18 With the superintendent acting as a father figure, caretakers sought to bring their patients back to sanity. ${ }^{19}$

The founding of the GHI and state asylums formalized the practice of psychiatry, shaping the profession by the growth of these institutions and the experiences of their superintendents. The new profession still reflected the same social concerns that shaped the asylums and did not deviate far from older trends in understanding or treating the mentally ill, but by the 1840 s there was a budding profession with a more systematic way to approach insanity and its treatment. In 1844, thirteen superintendents organized the Association of Medical Superintendents of American Institutions for the Insane (AMSAII) to set guidelines for the care of the mentally ill, including the design of institutions, their governing structure, and who was qualified to work with patients. Admission into this organization remained exclusive for a long time, based on experience within hospitals instead of training or education, but the AMSAII promoted a new

\footnotetext{
${ }^{17}$ By-Laws of the Government Hospital for the Insane, etc. September 1855. (Washington: G. S. Gideon, Printer, 1855), 21-23. Reports of the Government Hospital for the Insane, Vol. 1, 1855-1874. Office of the Chief Clerk, Department of the Interior. Record Group 48, Entry 298, Box 6. National Archives, College Park.

${ }^{18}$ Gerald Grob, Mental Institutions in America, 169.

${ }^{19}$ Gerald Grob, Mental Institutions in America, 165-170; Carla Yanni, The Architecture of Madness, 1-24, 68-71; Benjamin Reiss, Theaters of Madness: Insane Asylums and Nineteenth-Century American Culture (Chicago: The University of Chicago Press, 2008), 4-9.
} 
community of psychiatrists and gave them legitimacy in the eyes of the public. At this point the treatment of the insane officially separated from the criminal system; the AMSAII no longer wanted the mark of criminality on the mentally ill as it had been in the previous century. Due to the steady construction of mental hospitals and the communication between the AMSAII and the public, by the 1860 s mental illness and its institutions were familiar to the American public. By the start of the Civil War, the AMSAII had created a standard practice for use within institutions and most states had at least one mental hospital. ${ }^{20}$

While the essence of "moral treatment" remained in the insane asylums of the midcentury there was a large shift just before the Civil War. Before 1850, hospitals were built to create proper, therapeutic environment to cure patients in small numbers. By the 1860 s, the need had begun to outgrow the available asylum space. Large numbers of chronic or incurable patients challenged the previous optimism of curability and forced asylum physicians and state governments to reconsider the role of mental institutions in society. By the mid-century, wider dissatisfaction with government funding of social reform movements that had not resolved the social ills they were meant to fix led to new scrutiny and regulation of welfare institutions. In addition, the founders of psychiatry were fading away, replaced by a younger generation that was far more committed to somatic understandings of mental illness. Because the same environment or "exciting factors" could affect many but cause only a few to go insane, psychiatrists developed new theories that argued there must be factors within individuals that made them susceptible to mental illness. By the Civil War many believed that hereditary disposition could

\footnotetext{
${ }^{20}$ Gerald Grob, Mental Institutions of America, 130-150; See also, John Albert Pitts, "The Association of Medical Superintendents of American Institutions for the Insane, 1844-1892: A Case Study of Specialism in American Medicine (Ph.D. Dissertation, University of Pennsylvania, 1979).
} 
be the sole cause of insanity, placing the focus on the person's physical or moral weakness and away from the environment in which the insanity occurred. ${ }^{21}$

The standardized form for admission into the Eastern Lunatic Asylum in Kentucky asked for information regarding the "exciting cause of the insanity" and whether there was "a hereditary predisposition for insanity" or family members who were also insane. When referring to the "exciting causes" the form asks "Is it a moral cause, such as disappointment, fright, love, \&c., or a physical cause, such as fever, the immoderate use of intoxicating agents, bodily injury, serious illness, or accidental affecting the nervous system, \&c." ${ }^{22}$ Asylums were keenly interested in any possible hereditary cause of a patient's insanity and their moral habits, often dismissing other causes in deference to an insane family member or immoral habit, such as drinking or masturbation. ${ }^{23}$

During and after the war, many asylum superintendents did not see a connection between the experience of war and a higher rate of trauma or insanity beyond moral or physical ailments. When E. H. Van Deusen, of the Michigan Asylum for the Insane, argued that the patriotism leading Union men into battle prevented the development of any mental disease, he also stated that the only danger to soldiers was a decline in their morality due to being a soldier. "[I]n the camp, the hospital and the field, they are subjected to certain morbid influences...," he argued, "The list of causes, moral and physical, to which they will there be subjected, is a formidable

\footnotetext{
${ }^{21}$ Gerald N. Grob, The Mad Among Us: A History of the Care of America's Mentally Ill (New York: The Free Press, 1994), 105-128, 176, 219, 258; Norman Dain, Concepts of Insanity in the United States, 1789-1865 (New Brunswick, NJ: Rutgers University Press, 1964), 84-112; David J. Rothman, The Discovery of the Asylum: Social Order and Disorder in the New Republic (Boston: Little, Brown and Company, 1971), 237-238.

${ }^{22}$ The admission form for the Eastern Lunatic Asylum appears in multiple files in the Patient Commitment Records, Kentucky Department for Libraries and Archives, Accession No. A2001-195. Some files do not contain the actual form, but the same questions are referenced in the file.

${ }^{23}$ Questions about moral habits and hereditary are common in almost all the commitment records viewed for this study.
} 
one, and its aggregate of effect, we have one of the most afflictive of the dread 'evils of war." 24 Van Deusen points to a worrisome "disregard of the rights of others," "disposition to insubordination and lawlessness," and "a spirit of irreverence" that they could only hope would be checked by military discipline and authority. Superintendents, and the wider public, feared a class of soldiers with a damaged morality returning into society with "their tastes for domestic life destroyed, with no disposition to engage in honest and peaceful avocations." ${ }^{25}$ As Van Deusen concludes, "To the habits thus formed, we shall hereafter trace, most unquestionable, either directly or indirectly, very many cases of mental disease."26

Asylum superintendents and physicians often focused on the physical treatment of their insane patients, prescribing medicines or dietary regimes to improve the strength of the soldier. For example, when admitting an insane soldier of the $9^{\text {th }}$ Ohio Infantry who had been insane three weeks prior to arriving at Longview State Hospital, they noted his emaciated and sickly appearance for which they prescribed "[t]onic and strengthening regimen and remedies," writing that he was "much improved in general appearance and health" at his discharge. ${ }^{27}$ Wartime and post-war asylums focused on a mixture of "moral" and medical treatments to cure insane patients, including the use of narcotics and anodynes, tonics and stimulants, nourishing diets, warm baths, sleep, recreations, amusements, employment in small jobs, and religious worship. ${ }^{28}$

\footnotetext{
${ }^{24}$ Biennial Report of the Board of Trustees of the Michigan Asylum for the Insane, For the Years 1861-1862. (Lansing: John A. Jeer \& Co., Printers to the State, 1862). Falk Library, University of Pittsburg Health Sciences Library, Collection Ms 9, Insane Hospital Reports, Volume I, page 24-27.

${ }^{25}$ Ibid.

${ }^{26}$ Ibid.

${ }^{27}$ Ohio Historical Society, Longview State Hospital, Case History of Male and Female Patients, 1863-1918, (Call \#: State Archives Series 541) (BV4389), page 33.

${ }^{28}$ Many annual superintendent reports discuss the treatments used with insane patients, including: First Biennial Report of the Trustees, Superintendent and Treasurer, of the Iowa Hospital for the Insane, at Mount Pleasant. December 1861 (Des Moines: F. W. Palmer, State Printer, 1862). Falk Library, University of Pittsburg Health Sciences Library, Collection Ms 9, Insane Hospital Reports, Volume I, page 29-30; Annual Report of the Resident Physician of the New York City Lunatic Asylum, January 1, 1867. Falk Library, University of Pittsburg Health Sciences Library, Collection Ms 9, Insane Hospital Reports, Volume II, page 20-25; Report of the State of the New York Hospital and Bloomingdale Asylum, For the Year 1866. (New York: D. Van Nostrand, 1867). Falk Library,
} 
In addition to a focus on the somatic symptoms of their cases there is a marked emphasis on moral or hereditary causes. When a twenty-six year old soldier was admitted to Longview Hospital in November 1863 after deserting his regiment and being arrested by military authorities, he was described as periodically depressed and at times violent. His record entry notes, "He talks principally about the war. He now rests badly at night. He eats voraciously at times and then does not again take food for a day or two. He has several times tried to injure himself. The supposed exciting cause is the war. He was in the battle at Pittsburg Landing and seems to have been strongly affected by it. The disease is probably hereditary." ${ }^{29}$ While the admitting physician noted the excitement from battle as a possible contributor, he then pins the base cause of the insanity on hereditary. The entry notes that an uncle on the soldier's father's side of the family was also insane, thus leading to the conclusion that the disease was hereditary. The entry continues on to describe in detail the soldier's physical health and appearance, and physicians immediately placed him on a medicinal regimen to improve his physical health. ${ }^{30}$ Family history or physical causation was more easily evident in these cases, whereas the idea of a traumatized mind was not an accepted concept at the time, which lead to physicians looking at physical, family, or moral causation.

With the rise of psychiatry and the mental hospital in the decades before the war, it is likely that many Civil War medical personnel had some awareness of mental illness due to the written materials circulated by psychiatrists. Certainly, the physicians and staff at the Government Hospital for the Insane were trained in the latest institutional theories and

\footnotetext{
University of Pittsburg Health Sciences Library, Collection Ms 9, Insane Hospital Reports, Volume II, page 15-18; Twenty-Third Annual Report of the Board of Trustees and Officers of the Central Ohio Lunatic Asylum to the Governor of the State of Ohio: For the Year 1861. (Columbus: Richard Nevins, State Printer, 1862). Falk Library, University of Pittsburg Health Sciences Library, Collection Ms 9, Insane Hospital Reports, Volume I, page 29-30.

${ }^{29}$ Ohio Historical Society, Longview State Hospital, Case History of Male and Female Patients, 1863-1918, (Call \#: State Archives Series 541) (BV4389), page 56.

${ }^{30}$ Ibid.
} 
treatments. Largely, however, general physicians lagged far behind the specialists and were not very concerned with mental illness. Consequently, the physicians that went to war with the army either had no knowledge of mental illness and relied on traditional practices entirely or had some knowledge of the theory but no experience in actual diagnosis and treatment. These limited understandings of mental illness and insanity shaped the army's policies and reactions to soldiers who exhibited signs of mental trauma. ${ }^{31}$

One of the few categories of mental difficulty recognized by the Union Army was labeled "nostalgia," defined by The Medical and Surgical History of the War of the Rebellion as "a temporary feeling of depression [that] frequently pervaded our camps on account of discomfort, hardships and exposures, especially when these were recognized or assumed by our volunteer soldiers to be of a preventable or uncalled for nature." 32 The army blamed homesickness, physical hardships of the war, and inactivity during winter camps for the majority of the nostalgia cases, and only reported those cases that "developed to a morbid degree," usually due to temperament or troubles at home. They reported, also, that two types of soldiers were the most susceptible to the ailment: "young men of feeble will, highly developed imaginative faculties and strong sexual desires" and "married men for the first time absent from their families." 33 Maintaining activity of the mind and body to occupy the soldiers was the best suggested cure for nostalgia; it was considered dangerous to send these men home because other men might use it as a way to shirk their duties or get out of the service. ${ }^{34}$

\footnotetext{
${ }^{31}$ Norman Dain, Concepts of Insanity, 148-154.

32 The Medical and Surgical History of the War of the Rebellion. Part III. Volume I. Medical History (Washington: Government Printing Office, 1888), 884.

${ }^{33}$ The Medical and Surgical History of the War of the Rebellion, 884-885.

${ }^{34}$ The Medical and Surgical History of the War of the Rebellion, 884-886; Albert Deutsch, "Military Psychiatry: The Civil War, 1861-1865," in One Hundred Years of American Psychiatry (New York: Columbia University Press, 1944), 339-379; United States Sanitary Commission, Sanitary Memoirs of the War of the Rebellion (1867), 20-29. Accessed on GoogleBooks, February 25, 2014; J. Theodore Calhoun, "Nostlagia: As a Disease of Field Service," Medical and Surgical Reporter (1858-1898), February 27, 1864 11, 9, American Periodicals, p. 130.
} 
In order to reduce the chances that nostalgia or mental illness would become an easy "out" for soldiers, the army put specific regulations in place regarding the treatment and discharge of soldiers declared insane. The overall policy of the army was to not allow the discharge of soldiers before their enlistment expired, except due to a court-martial sentence or a certificate of disability. The process to receive a certificate of disability was involved and timeconsuming. If an enlisted man became unfit for duty their captain had to write up a statement of his case with a certificate of disability signed by the senior surgeon of the hospital, regiment, or post where the solider was and forward it to either the commander of the department or of the army in the field by way of the commander of the regiment or post. This process required the captain to acknowledge the soldier's status as unfit for duty, as well as the surgeon (which would be easy or difficult depending on the soldier's symptoms and the surgeon's attitude toward unconventional illnesses), and the paperwork to go through at least one step of approval before making its way to the commander of the department. At that point, if the application was approved the certificate of disability would be endorsed and sent back to the commanding officer who would sign it and forward the certificate to the Adjutant General's Office which kept the records of each soldier. ${ }^{35}$ A physical illness or disease was far easier to prove than mental illness or trauma in the Civil War, yet even soldiers who were deemed physically unfit for duty might not be given a certificate of disability; instead, soldiers who could still be useful in lighter duties were reassigned to the Invalid Corps, later known as the Veteran Reserve Corps. Only those soldiers suffering from specific deformities, injuries, or ailments were exempt from the Invalid

\footnotetext{
${ }^{35}$ George Patten, Lt.-Col., Patten's Army Manual: Containing Instructions for Officers in the Preparation of Rolls, Returns and Accounts Required of Regimental and Company Commanders, and Pertaining to the Subsistence and Quartermasters' Departments (New York: J. W. Fortune, 1862), 213-214.
} 
Corps and discharged. ${ }^{36}$ In The Army Surgeon's Manual "manifest imbecility or insanity" is first in the list of infirmities that disqualify men for the Invalid Corps. In addition, the Surgeon General's Office specifically stated that "no insane soldier can be discharged from the service on Surgeon's Certificate of Disability."37

Instead of receiving a discharge, insane soldiers were supposed to go to the Government Hospital for the Insane (GHI) in Washington, D.C. In General Orders No. 98, issued November 13, 1861, the Adjutant General's Office declared that "the insane of the military service are entitled to treatment in the Government Hospital established in this city," and set up procedures to send soldiers to the GHI for treatment. ${ }^{38}$ Admission into the hospital necessitated an application to the Adjutant General including the patient's information, a description of the soldier, copies of his pay and clothing accounts, and a declaration of insanity and further information from the surgeon of the regiment. Ideally, the application would reach Washington at least a day before the soldier, allowing the Adjutant General's Office and the GHI to prepare for his arrival. Each insane soldier was to be accompanied by attendants (who were provided supplies and transportation means to and from Washington) to ensure his safe arrival at the GHI. $^{39}$

At least some men were properly handled under this system as evidenced by this letter written by General Benjamin Butler from New Orleans to Secretary of War Stanton in October 1862 reporting that: "I have the honor to report that I have forwarded... under the charge of Capt.

\footnotetext{
${ }^{36}$ For the list of "physical infirmities that incapacitate enlisted men for field service, but do not disqualify them for service in the Invalid Corps" and the list of "physical infirmities that disqualify men for service in the Invalid Corps" see William Grace, The Army Surgeon's Manual: For the Use of Medical Officers, Cadets, Chaplains, and Hospital Stewards. [Reprinted with a Bibliographical Introduction by Ira M. Rutkow, M .D., Dr. P. H.] (San Francisco: Norman Publishing, 1992), 72-75.

${ }^{37}$ William Grace, The Army Surgeon's Manual (1992), 155.

${ }^{38}$ William Grace, The Army Surgeon's Manual (1992), 35-36

${ }^{39}$ Ibid.
} 
Puffer, certain discharged soldiers, three insane men, and three clergymen...The insane men Capt. Puffer will take with him to Washington, and deliver to the 'Soldiers Insane Asylum."'40 Orange G. Kerr of the $9^{\text {th }}$ New York Cavalry is an example of a soldier treated properly under army policy. After receiving a sunstroke and becoming unconscious in the summer of 1862, comrades reported that Kerr would sit for a long time unaware of his surroundings, would not respond when spoken to, would drool at the mouth, and would defecate without moving to a latrine. Testimony in Kerr's pension file states that he remained with his company for a few days in that condition under the care of comrades and then the regimental surgeon declared him insane and transferred him to the GHI. ${ }^{41}$ According to the yearly reports of the GHI, the institution admitted 1,505 patients from the army and seventy-seven from the navy between July 1, 1860 and June 30,1867, as well as some patients from the Soldier's Home in Washington, D. C. and a few Confederate prisoners. ${ }^{42}$

The use of the GHI and the military's policies for the transportation of insane soldiers to this institution shows that the Union army did acknowledge some mental illnesses among their soldiers. However, during the course of the war there is evidence that these policies were not entirely successful. In November 1864, Surgeon General Joseph K. Barnes replied to concerns of the AMSAII, clarifying policy for treating insane soldiers. He was responding to a letter from

\footnotetext{
${ }^{40}$ Benjamin Franklin Butler, "Letter from Benjamin Franklin Butler to Edwin McMasters Stanton, October 25, 1862," in Private and Official Correspondence of Gen. Benjamin F. Butler During the Period of the Civil War, vol 2 (Springfield, MA: Plimpton Press, 1917), 407. American Civil War: Letters and Diaries, accessed 28 January, 2014 (Butler: L1986-431).

${ }^{41}$ Orange G. Kerr pension application 718096 and certificate 564812. National Archives, Washington D.C.

${ }^{42}$ These statistics come from the annual reports of the Board of Visitors, Superintendent of Construction, and the Hospital Superintendent for the Government Hospital for the Insane. Reports of the Government Hospital for the Insane, Vol. 1, 1855-1874. Office of the Chief Clerk, Department of the Interior. Record Group 48, Entry 298, Box 6. National Archives, College Park. Each year, the superintendent reported a break down of the previous patients still in the hospital, admissions, discharges/deaths, and the new number of patients for the fiscal year (July-June). The numbers listed here are the compilation of the admission numbers for the army and navy for the years in question. Eric T. Dean, Jr. cites a different number in his book, Shook Over Hell-he states that 1,231 men were treated at the GHI during the war. This difference in statistical numbers is most likely to do with a different year range for each study.
} 
three asylum superintendents concerned about insane soldiers left to wander by themselves with no access to treatment or who became insane in places where treatment at the GHI was not easily reached. They reported many soldiers of this type left to wander alone after being sent home from the army or discharged from the hospital. Many were too ill to make their way home safely and were the subject of robbery and abuse. The superintendents reported that "One poor fellow was passed over a long line of railroads, by the conductors, nearly destitute of clothing, and having a card attached to his hat marked 'Michigan.' He was left in the depot at Kalamazoo."43 These soldiers were not competent enough to travel on their own. "Another was found in the woods in a helpless state, trying to get home," wrote the concerned physicians, and "a Methodist minister, a non-commissioned officer, left the army, in Tennessee, insane, and, at length found his way home in one of the Western States, having on the way lost his baggage, watch and money, and most of his clothing. Another was found nude in the streets of a village."44 The superintendents were also concerned with soldiers who may have deserted while insane and were then confined as vagrants or under the charge of desertion, those who became insane in locations too remote from the GHI and might be endangered if they left their current hospital, and soldiers who became insane while at home on furlough who might be charged with desertion if they did not return to the ranks in order to receive treatment. ${ }^{45}$

Barnes' reply stated that "insane soldiers found at large, without protection or guardians, may be sent to the nearest Asylum, and, if reported to the Adjutant-General, an order will be given without delay for their transfer to the Government Asylum.."46 This allowed the insane to

\footnotetext{
43 "Instructions from the Surgeon General Respecting Insane Soldiers," written November 7, 1864 by John P. Gray, E. H. Van Deusen, and Wm. P. Jones. Medical Officers of the New York State Lunatic Asylum, ed. The American Journal of Insanity Vol. XXI (Utica, NY: State Lunatic Asylum, 1864-5), 462-465.

${ }^{44}$ Ibid.

${ }^{45}$ Ibid.

${ }^{46}$ William Grace, Army Surgeon's Manual, For the Use of Medical Officers, Cadets, Chaplains, and Hospital Stewards, Containing the Regulations of the Medical Department, all General Orders from the War Department,
} 
receive treatment and protection faster, and is the reason why many insane soldiers did not end up at the GHI. In addition, the Surgeon General addressed the issues of taking care of the expenses for treating insane soldiers in other institutions, ensuring that if a soldier was on furlough or died while in an asylum they would be protected from the charge of desertion and eligible for back pay and pension, and allowed a superintendent from another institution to issue a sworn statement as proof of the soldier's institutionalization and regulated proper notification to the army in that case. Between the GHI and the assistance of other institutions as explained in this correspondence, the Surgeon General was confident that they had met the needs of insane soldiers. ${ }^{47}$ Yet the fact that three years after the issuance of General Orders No. 98 the AMSAII was concerned enough about the plight of untreated insane soldiers to appoint a committee to correspond with the Surgeon General on the matter shows that many men were not receiving treatment as laid out in the Union army's policies.

Despite the Surgeon General's confidence in the army's policies, even soldiers who did make it to the GHI for treatment could struggle to return home after their discharge. In two letters dated October 17, 1884 and April 21, 1891 the children of John Garstner of the $16^{\text {th }}$ Massachusetts seek information about their father who disappeared after his stay at the GHI. According to the family's correspondence with the Adjutant General and the last letter they had received from John, Garstner was admitted to the GHI in October 1863 and then discharged from the army and hospital in early December of that same year. But he never returned home, and the family had heard no information since his discharge. In the first letter, his daughter Annie states that the "Adjutant General suggested that possibly my father, after his discharge, had a relapse

and Circulars from the Surgeon-General's Office. From January 1st, 1861, to April 1st, 1865 (New York: Balliere Brothers, 1865), 201-202.

${ }^{47}$ Ibid. 
and may have been admitted to the Hospital again as a discharged soldier" and had sent her directly to the institution for more information. The fact that there is a second letter written by an attorney several years later asking for the same information, almost thirty years after Garstner's reported discharge, suggests that he never made it home and the family never received answers about their father's fate. ${ }^{48}$

The main reason soldiers went untreated despite the procedures covering insane men was the army's policy to keep manpower on the frontlines during the war. Many officials were convinced that any man seeking medical attention or discharge due to a mental or physical disability was a shirker who should be returned to duty. Likewise, doctors saw it as their responsibly to return shirkers to their units and were on the lookout for feigned insanity in the men seeking their care. Doctors treated those who did exhibit physical signs of mental trauma for those physical symptoms and if the doctor found "nothing wrong" they treated the men like malingerers. Even the recognized condition of "nostalgia" was connected to malingering. A publication about the war from the United States Sanitary Commission stated, "The moral causes affecting the physical stamina of the soldier include cowardice, weakness of will, nostalgia, and malingering...Cowardice usually finds expression in malingering, weakness of will, and nostalgia..."49 From a twentieth-century view, some, if not many, of these cases would be recognized as psychiatric casualties. However, in the conditions of the Civil War it could be very difficult to tell exactly what a patient was suffering from, whether illness, psychological stress, exhaustion, or a combination of factors. ${ }^{50}$

\footnotetext{
${ }^{48}$ Letter: October 17, 1884 from Annie Garstner to W. W. Godding (GHI), and letter: April 21, 1981 from J. F. Vinal, Atty to Superintendent of Hospital for the Insane. Records of St. Elizabeth's Hospital, Record Group 418, Case \#1115 John Gerstner. National Archives, Washington, D.C.

${ }^{49}$ United States Sanitary Commission, Sanitary Memoirs, 20-21.

${ }^{50}$ Eric T. Dean, Jr., Shook Over Hell: Post-Traumatic Stress, Vietnam, and The Civil War (Cambridge, MA: Harvard University Press, 1997), 118-120, 133-134.
} 
In several books written during and directly after the war, army surgeon Roberts Bartholow warned of the soldier who feigned his illness to get out of duty or out of the service entirely. Feigning illness was widespread in the army, according to Bartholow, and resulted from laziness in the face of service and physical hardship, disappointment in one's position within the army, medical officers who were too lenient, and the realization that the sick went home on furlough or were discharged entirely. He warned medical officers to be very cautious and suspicious of the men who came to them for treatment, and arm themselves with as full a knowledge of diseases and injuries as they could to detect the feigners among the truly afflicted. According to Bartholow, surgeons must carefully question the soldier about his ailments and look for him to make any mistakes about the symptoms and causes of his injury or illness, and question other trusted men in the wards about the behavior of the soldier in question in case he broke character while the surgeon was not present. "As "As the man's object is either to avoid duty or procure a discharge from the service," Bartholow advised, "he should be early informed that the first may succeed for a short time, but that the last is utterly impracticable. To deprive the malingerer of hope is to contribute greatly to his cure." ${ }^{52}$ Bartholow advised the surgeon to be discreet, to call the soldier's ruse to prevent his unnecessary absence from his unit, but to do so privately and to prescribe a placebo if necessary to allow that soldier to maintain his reputation among his comrades. But, he warned, "as a rule, it is better for the military surgeon, in all cases of doubt, to suspect any soldier of feigning whose symptoms are obscure, unreasonable, or

\footnotetext{
${ }^{51}$ Roberts Bartholow, M. D., A Manual of Instructions for Enlisting and Discharging Soldiers; With Special Reference to the Medical Examination of Recruits and the Detection of Disqualifying and Feigned Diseases. [Reprinted with a Biographical Introduction by Ira M. Rutkow, M. D., Dr. P. H.] (San Francisco: Norman Publishing, 1991), 86-91, 99, 101-102.

${ }^{52}$ Roberts Bartholow, A Manual, 100-101.
} 
improbable." ${ }^{53}$ Following these guidelines, any soldier whose ailment was invisible or did not fit the mold of an established injury or illness was a malingerer. ${ }^{54}$

Bartholow classified feigned illnesses into eight categories, and detailed each illness that was commonly feigned. Deafness was the most commonly feigned illness in the service, but also easily detected. Other feigned illnesses included problems with eyesight, stammering, sudden dumbness, the inability to speak, heart disease, vomiting and diarrhea, lameness and joint pain, and mutilation of the hands. Bartholow suspected soldiers who complained of pain in the body without a specific location or apparent cause of simulating the injury. Sudden paralysis was also cause for suspicion. As for mental illness, Bartholow suggests that it is not a commonly feigned disease due to the difficulty of maintaining the charade for long periods of time. ${ }^{55}$ In all cases, he repeatedly cautioned that "no disease should be accepted as real, when the man has a motive for deception, without proper examination and inquiry." 56

Of course, there were certainly cases of feigned insanity during the Civil War that confirmed the suspicions of Bartholow and other medical personnel. When speaking of a particular patient within her wards at Jefferson Barracks, MO, Elvira J. Powers described a man who would sit daily with a bent pin on a hillside "fishing" on dry ground. While ridiculed and pitied by others in camp for his supposed insanity, once he received his discharge, "when flourishing it in their faces, he informed them that it was 'now his turn to laugh, as he had received what he had all along been fishing for-viz: a discharge!",57 "Fishing" for a discharge

\footnotetext{
53 Ibid.

${ }^{54}$ R. Gregory Lande, Madness, Malingering, and Malfeasance: The Transformation of Psychiatry and the Law in the Civil War Era (Washington, D.C.: Brassey's, Inc., 2003), 131-134.

55 Roberts Bartholow, A Manual, 107-148.

${ }^{56}$ Roberts Bartholow, A Manual, 135.

${ }^{57}$ Elvira J. Powers, "Diary of Elvira J. Powers, April 1864,” In Hospital Pencilings: Being a Diary while in Jefferson General Hospital, Jeffersonville, Indiana and Others at Nashville, Tennessee, as Matron and Visitor (Boston: E. L. Mitchell), 218. American Civil War: Letters and Diaries, accessed 28 January, 2014 (Powers: D9751). Emphasis theirs.
} 
seemed to be popular activity as charged by Elisha Doty in testimony for the pension of William Gardiner of the $22^{\text {nd }}$ NY Cavalry. While several of Gardiner's comrades testified to his irrational behavior in the war, after describing Gardiner dancing and having crazy spells Doty concluded, "I remember when he was discharged, after he got his discharge he says boys that is what I have been fishing for." 58 While these stories of "fishing" for discharges may be overly exaggerated, they demonstrate that the idea of malingering was widespread in the army and both soldiers and physicians were suspicious of comrades acting in strange ways.

Asylums also received soldiers in their wards that they deemed shirkers. One patient who was admitted to Longview State Hospital in April 1863 had left his regiment and walked home the winter after he enlisted. According to the pension application of his widow, she had determined him not in his right mind and sent him to the asylum. ${ }^{59}$ The admitting physician did not quite agree with the soldier or his wife, stating the patient "had joined the army and was tired of acting soldier and thought the best way to avoid serving longer was to take a fit of insanity and be sent to the Asylum which he accordingly did, and we believe succeeded in obtaining a 'discharge' by doing so." ${ }^{60}$ As with any war, some men looked for a way out of service. Malingering and feigning illness most certainly did happen on some level during the Civil War. However, most soldiers seeking treatment may have been suffering from mental stress and exhibiting symptoms that did not fit into a standard mold of what surgeons were looking for in a sick or injured patient.

Instead of seeing war experience as a possible cause of insanity in Civil War soldiers, military medical officers and hospital superintendents tried to pinpoint the flaws within the men

\footnotetext{
${ }^{58}$ William V. Gardiner, pension application 363852, certificate 1132728, National Archives, Washington, D.C.

${ }^{59}$ Widow application 1555726, National Archives, Washington, D.C.

${ }^{60}$ Ohio Historical Society, Longview State Hospital, Case History of Male and Female Patients, 1863-1918 (Call \#: State Archives Series 541) (BV4389), page 5.
} 
who ended up in their institutions. In Bartholow's manual he categorized the usual casualties of nostalgia as young men "belonging to races and people remarkable for their attachment to home and country" or married men, "particularly those given to solitary vice or the victims of spermatorrhea." ${ }^{61}$ What the military needed was men with strong mental characteristics: "a spirit of enterprise and an intellectual hardihood which render him superior to fatigue; an easy bearing under defeat, and a buoyant self-confidence which misfortunes do not easily depress."62 According to Bartholow's contribution to the memoirs of the United States Sanitary Commission, each race (Celtic races, Germans, Negros, and the "mixed race of New Mexico") had different mental and moral qualities that either assisted their military service or harmed it by creating weaknesses of the mind that showed themselves under the pressure of war. ${ }^{63}$

In his yearly reports, the Superintendent of the Government Hospital for the Insane, Dr. Charles H. Nichols, commented frequently on the patients admitted during the war, but did not connect wartime experience to the rise in insane cases. In July 1861, he wrote, "A large proportion of the land forces are men of no little moral and nervous susceptibility, quickly transferred from the quietude, comforts and sympathies of home to all the hardships and profound excitements of camp and field." ${ }^{64}$ The following July, when speaking of the record keeping, or lack thereof, of the causes of insanity among GHI patients (largely due to the

\footnotetext{
${ }^{61}$ Roberts Bartholow, A Manual, 21-22. Spermatorrhea is a disease that involves involuntary ejaculation due to problems with the kidneys. Masturbation was also seen as a disturbing sign of mental illness in nineteenth century medicine.

${ }^{62}$ Roberts Bartholow, "The various influences affecting the physical endurance, the power of resisting disease, etc., of the men composing the volunteer armies of the United States," In Sanitary Memoirs of the War of the Rebellion; Collected and Published by the United States Sanitary Commission (1867), 4.

${ }^{63}$ Roberts Batholow, "The various influences," 4-5; See also, United States Sanitary Commission, Sanitary Memoirs of the War of the Rebellion (1867), 20-29. Accessed on GoogleBooks, February 25, 2014.

${ }^{64}$ Reports of the Board of Visitors and the Superintendent of Construction of the Government Hospital for the Insane, for the year 1860-1861 (Washington: Gideon \& Pearson, Printers, 1864), 17-20. Reports of the Government Hospital for the Insane, Vol. 1, 1855-1874. Office of the Chief Clerk, Department of the Interior, Record Group 48, Entry 298, Box 6. National Archives, College Park.
} 
inaccurate reporting from the field), Nichols commented on the results presented in reports from state institutions: "Those tables, if they do not always express all the circumstances, not even the most important one, which culminated in insanity, do, it seems to us, throw much interesting light both upon history and habits of the individual, and upon the religious, social, and industrial habits and tendencies of communities." ${ }^{65}$ The reports of these early years reinforced the antebellum idea that individuals can produce their own mental illness through poor behavior and that the causes of wartime insanity lie within a soldier's moral weakness.

This view did not change over the period of the war, for in 1863 and 1864 the superintendent drove this point more forcefully. Although admissions almost doubled from 1862 to 1863 , Nichols reported that "it is gratifying to be assured that neither the existence of the war, doubt as to the justice of our cause, not distrust as to its final result, is to be imputed as the cause of the malady with which the patients have been afflicted, but that it is rather the result of overtasked efforts of constitutions previously impaired by sickness contracted in the line of duty." ${ }^{66}$ He continued on, later in his report, to state that "[i]t should not be inferred that the war has been a prolific moral cause of insanity." ${ }^{\prime 67}$ According to Nichols in a very small minority of cases "has even the exciting cause of mental disorder appeared to have been either the profound excitements attending a personal participation in active military hostilities prosecuted on the largest scale, a sense of great personal danger in battle, or anxiety and misgivings respecting the result of a great contest in which every man of much moral susceptibility feels the deepest

\footnotetext{
${ }^{65}$ Reports of the Board of Visitors and the Superintendent of Construction of the Government Hospital for the Insane, for the year 1861-1862 (Washington: Gideon \& Pearson, Printers, 1864), 16-17. Reports of the Government Hospital for the Insane, Vol. 1, 1855-1874. Office of the Chief Clerk, Department of the Interior, Record Group 48, Entry 298, Box 6. National Archives, College Park.

${ }^{66}$ Reports of the Board of Visitors and the Superintendent of Construction of the Government Hospital for the Insane, for the year 1862-1863 (Washington: Gideon \& Pearson, Printers, 1864), 3. Reports of the Government Hospital for the Insane, Vol. 1, 1855-1874. Office of the Chief Clerk, Department of the Interior, Record Group 48, Entry 298, Box 6. National Archives, College Park.

${ }^{67}$ Ibid, 18-23.
} 
personal stake." 68 Well into the Civil War, the GHI and the state asylums that followed its procedure, continued to see insane soldiers as a result from personal weakness and not wartime experiences.

In July 1864, after a year which saw the highest number of admissions at the GHI and in the midst of possibly the most brutal year in the war, the superintendent still pointed to the weakness of the soldier as the cause of increased numbers of insane soldiers, stating "that the latter accessions to the Union armies include a larger proportion of men who are more readily affected by the exciting causes of insanity then were to be found during the first two years of the war." ${ }^{69}$ He continued on to state, "It is obvious that if the recruit lacks the mental vigor and endurance necessary to receive and practice the discipline and instruction of a soldier, he will involuntarily betray both his companions and his country in the hour of battle - the hour of his supreme trial—and render worse than useless a costly novitiate."70 While an increase in the number of men serving in the military increased the population from which insane soldiers come, and there are personal factors which might cause a person to go insane, it also stands to reason that the increased numbers of mental casualties may reflect the progression of the war and the experiences of the men fighting it.

Medical treatment outside the asylum fell in line with the causes of insanity ascribed to by superintendents at the GHI and state institutions. With the physical understandings of insanity, some wartime physicians focused on diseases of the nervous system to explain the symptoms they were seeing in their patients. Doctors S. Weir Mitchell and Jacob DaCosta-

\footnotetext{
${ }^{68}$ Ibid, 18-23.

${ }^{69}$ Ninth Annual Report of the Board of Visitors, and the Twelfth Annual Reports of the Superintendent of Construction, Government Hospital for the Insane, for the year 1863-1864, 721-722. Reports of the Government Hospital for the Insane, Vol. 1, 1855-1874. Office of the Chief Clerk, Department of the Interior, Record Group 48, Entry 298, Box 6. National Archives, College Park.

${ }^{70}$ Ibid.
} 
known for their studies of nerve injury and "soldier's heart," respectively—both operated in Turner's Lane Hospital in Philadelphia, a specialized institution set up on the request of Surgeon General William Hammond to treat nervous disorders. ${ }^{71}$ While many of the cases examined by these two physicians exhibited symptoms that today might be interpreted as connected to mental breakdown or stress, Da Costa and Mitchell looked at them as problems of the heart and nerves. The studies produced from the research done at Turner's Lane Hospital are considered by doctors and historians as the foundation of the field of cardiology, not psychiatry. ${ }^{72}$

One ward of Turner's Lane Hospital was dedicated to the study of “exhausted hearts” by Dr. Jacob Da Costa. The men under Da Costa's care showed symptoms such as "fits of fluttering cardiac action," "cardiac irritability," shortness of breath, high pulse rates, fainting, coughing up blood, "valvular murmurs," "friction rubs," and perceived enlargement of the heart. Da Costa and other surgeons noted that many cases of "soldier's heart" occurred after "cardiac overexertion" caused by mental stress, determining that psychological factors worsened a physical ailment. In Medical Diagnosis, published by Da Costa in 1864, he divided his cardiac cases into two categories: functional disorders and organic disorders. Functional disorders occurred when there were symptoms of a cardiac disorder present, but no structural damage to the heart, and organic disorders were those where there were noticeable changes to the structure

\footnotetext{
${ }^{71}$ Ira M. Rutkow, Bleeding Blue and Gray: Civil War Surgery and the Evolution of American Medicine (New York: Random House, 2005), 253-4; S. Weir Mitchell is most known for developing the idea of the "phantom limb" from his work with amputees and injuries to the nervous system. Hammond was Surgeon General until 1863, but also specialized in mental and nervous disorders in the post-war period, see William A. Hammond, M. D., A Treatise on the Diseases of the Nervous System. With One Hundred and Twelve Illustrations, Eighth Edition, with Corrections and Additions (New York: D. Appleton and Company, 1886); William A. Hammond, ed. Military Medical and Surgical Essays, prepared for the United States Sanitary Commission (Philadelphia: J. B. Lippincot \& Co., 1864); and William A. Hammond, A Treatise on Insanity in its Medical Relations (New York: Amo Press, 1973 [originally published 1883]).

${ }^{72}$ Charles F. Wooley, M.D. "Jacob Mendez DaCosta: Medical Teacher, Clinician, and Clinical Investigator," The American Journal of Cardiology 50 (November 1982): 1147; Charles F. Wooley, The Irritable Heart of Soldiers and the Origins of Anglo-American Cardiology: The US Civil War (1861) to World War I (1918) (Burlington, VT: Ashgate Publishing Company, 2002), 5.
} 
of the heart, for example in the walls, membranes, or valves. The army was concerned that there might be a heart condition specifically affecting soldiers, spurring the need for Da Costa's research. Among soldiers suffering from symptoms of heart disease, if the soldier's symptoms did not match those of recognized organic diseases, they were labeled as having a functional disease. Although many of the three hundred cases Da Costa studied suggest a psychogenic foundation, he defined "soldier's heart" as a physical, functional abnormality. ${ }^{73}$

Da Costa's colleague at Turner's Lane, S. Weir Mitchell defined and treated insanity as caused by physical damage to the nerves or nervous system, legitimizing pain or symptoms that were otherwise hard to pin down. Mitchell's treatment strategy focused on testing patients to find the source of the nerve injury or disease, weed out malingerers, and use techniques to restore patients to stability. Like Bartholow, Mitchell was very concerned with those feigning symptoms to remove themselves from duty and would use techniques such as questioning men under anesthesia or shock therapy to reveal or cure the malingerer. For those he deemed suffering from a nerve injury, Mitchell developed "rest cure," a treatment of controlled diet, medicines, bed rest, massage, and, later on, shock therapy. His idea was to restore the injured soldier to discipline, obedience, and masculinity in order to cure the internal wounds and return the soldier to duty. ${ }^{74}$ As Lisa Long explains, "His rehabilitative work both returns health to the ill and stabilizes the identities of those who dare to feel something they should not given the way that social norms dictated bodily performance at the time." ${ }^{, 75}$ Mitchell took great care to record the cases he worked on in order to capture symptoms and ailments not usually treated in civilian medical

\footnotetext{
${ }^{73}$ Alfred Jay Bollet, Civil War Medicine: Challenges and Triumphs (Tucson, AZ: Galen Press, LTD, 2002), 321 322; Charles F. Wooley, The Irritable Heart of Soldiers, 12-35.

${ }^{74}$ Mitchell becomes notorious for his use of the same techniques in the post-war period to cure "hysterical" women by using "rest cure" and other therapies to return women to proper forms of femininity.

${ }^{75}$ Lisa A. Long, Rehabilitating Bodies: Health, History, and the American Civil War (Philadelphia: University of Pennsylvania Press, 2004), 44.
} 
practice and offered the first detailed study of traumatic neuroses. In the end, Mitchell's therapies could maintain a disciplined body, but did not cure many of the mental ailments suffered by soldiers. $^{76}$

Army physicians and officers facing cases of mental trauma were largely untrained in how to handle mentally affected soldiers and had to balance their understandings of the causes of insanity with the need to keep men in the front lines. Treatment "on-the-ground" within regimental units varied depending on the military and medical personnel in charge and combined elements of the policies emerging from army hospitals and insane asylums. Demonstrating the combination of several of these factors is the case of William Goodell of the $6^{\text {th }}$ Vermont Infantry. While fighting at White Oak Swamp in 1862 a shell exploded behind Goodell, knocking him unconscious. Although there were no signs of physical injury, when he awoke Goodell could not speak. Believing it to be an injury to the brain, Goodell's physician treated him by placing ice on his head, opening veins in his neck to release blood, giving him purgatives to induce vomiting and diarrhea, and blistering his legs, all reminiscent of traditional treatments relying on the four humors. These treatments lasted for several weeks in an attempt to reduce the inflammation in Goodell's body believed to be causing the perceived brain injury. When traditional treatments failed the physician next believed Goodell to be feigning his ailments, testing the patient through etherization; the physician dropped ether onto a sponge held to Goodell's nose and questioned him as he became insensible. The physician concluded that Goodell was telling the truth about his symptoms and proceeded to use jolts of electricity to undo

\footnotetext{
${ }^{76}$ Ira M. Rutkow, Bleeding Blue and Gray, 253-4; Lisa A. Long, Rehabilitating Bodies, 29-49; Nancy Cervetti, S. Weir Mitchell, 1829-1914: Philadelphia's Literary Physician (University Park: Pennsylvania State University Press, 2012), 75-81; S. Weir Mitchell, George R. Morehouse, and W. W. Keen, Jr. Reflex Paralysis: Circular No. 9 , Surgeon General's Office, March 10, 1864. A Reprint: With Introduction (Yale University School of Medicine, 1941).
} 
the body's "excitement." After the new treatments failed over six months, the physician finally sent Goodell home. Fifteen years later Goodell remained incapacitated and requested a pension for his injuries. ${ }^{77}$

The suspicion of malingering or feigning insanity played a part in several cases. When George Bolsinger of the $85^{\text {th }}$ Pennsylvania did not report to duty for a gunboat expedition, $1^{\text {st }}$ Sergeant John G. Stephens went to his tent to find him. He testified for Bolsinger's pension that he "found him all undressed except his shirt, he was hunting mice, I thought he was playing off. I had some of the men to dress him and put him on the gun boat. I was bound that he should not play off on me - consequently I would not send any men in his place. When he returned he was crazy and was that way as long as he was in the co. He never was fit for duty." ${ }^{\text {, }}$ It is possible George was already suffering from insanity before this encounter with Stephens; other testimony mentions that he was home at some point during the war and already showing signs of mental instability before officers arrived and took him back to the army, and the Adjutant General's report shows him deserted in the winter of ' 62 and returned to the company on the Jan/Feb ' 63 record. He eventually spent some time in the GHI before his discharge and later was admitted to the Kansas State Insane Asylum for a period of time in the 1880 s. $^{79}$

In a pension claim for a soldier in the $71^{\text {st }}$ Ohio, witnesses claimed the mental derangement stemmed from hardships, exposure, and overexertion near Elk River Bridge, Tenn. A supporting deposition by comrade Jacob Crone criticized the treatment of this soldier, stating he "frequently observed that the said [soldier] was placed on duty when he was not able to do duty. This was done by reason of the officers not knowing the nature of his disability and

\footnotetext{
${ }^{77}$ Ira M. Rutkow, Bleeding Blue and Gray, 39-40.

${ }^{78}$ George W. Bolsinger pension application 594088 and certificate 586593. National Archives, Washington, D.C.

79 Ibid.
} 
believed he was playing off. This was done for some time after he was first affected until it was ascertained that he was suffering from mental derangement." ${ }^{80}$ In this case, and that of Bolsinger, officers understood their men's' behavior as malingering, through the lens that they must keep men on the front lines to perform their duty, rather than seeing a mentally incapacitated soldier. Many men not diagnosed or sent to a hospital for treatment remained on the front lines. In some instances, if comrades noticed a man who was unable to perform his duties they kept the afflicted in camp, gave him lighter duties, and excused him from combat. In cases of criminal actions, if the accused was deemed insane they were discharged or sent to a hospital, instead of facing punishment. ${ }^{81}$ Testimony in the pension file of a soldier in the $150^{\text {th }}$ Pennsylvania Infantry shows that he suffered from sunstroke and/or the effects of a shell bursting near his head in May or June 1864 during the Overland Campaign. He was initially treated in a hospital for the sunstroke and then returned to the regiment, only to fall ill with sunstroke again. Following the second attack he was excused from picket duty in order to keep him with the regiment because it became clear to his comrades that something was wrong with his mind. Despite this, however, it was not until January of 1865 that the assistant surgeon sent him to a Division Hospital for treatment. After his discharge the soldier was quickly admitted to Dixmont Asylum in Pennsylvania where he did not improve, was discharged in May 1868, and died that August from the effects of his Civil War service. ${ }^{82}$ Another soldier, James Boland of the $1^{\text {st }}$ New York Mounted Rifles, was kept in the regiment nearly a year after his first symptoms of insanity developed. During the winter of 1862/63 he tried to shoot at his colonel while yelling that he had

\footnotetext{
${ }^{80}$ Pension application 185109 and certificate 140569; widow application 323055 and certificate 218049. National Archives, Washington, D.C.

${ }^{81}$ R. Gregory Lande, Madness, Malingering, and Malfeasance, 157-167.

${ }^{82}$ Pension application 86659, Father's pension application 244478 and certificate 206387. National Archives, Washington, D.C.; Volume II on Roll 6/1865-8/1866, RG-23 Records of the Department of Public Welfare, Dixmont State Hospital, Patient History Books, 1859-1950 (2 $2^{\text {nd }}$ Roll, 1863-1866) (Roll 19), Pennsylvania State Archives.
} 
shot the Holy Ghost. Because his behavior was irrational he was released from arrest and relieved of all military duties, except some around camp. The regiment kept him with them for a full year; it was not until the next winter, after he had roamed the camp naked threatening people with an ax, that he was finally sent to the asylum at Washington, D.C. ${ }^{83}$ Cases such as these demonstrate not only the tendency of officials to keep men on the front lines, but also the failure of army policy put in place to transfer insane men quickly to the GHI or state asylums.

Sometimes officers and doctors treated an identified physical ailment but overlooked the mental ailments present in the same soldier. Eighteen year old Jonathan Rist contracted measles around the time of Cold Harbor in 1864 while serving with the $96^{\text {th }}$ New York Infantry and was taken to a hospital where he worsened with a case of Typhoid Fever. Rist testified for his pension that he returned to his regiment at the beginning of September 1864 where he was engaged in the battle of Fort Harrison at the end of the month but was also "excused from active duty by his officers" during the month. Treated for his measles and Typhoid Fever, Rist was returned to his unit mentally unwell. Supporting depositions from comrades testified that Rist returned to the regiment sometime in October (unsure why the dates are different) and was in a state of mental confusion, wandering the camp and unaware of dangers around him, such as passing teams of horses. He must have remained in this condition with his regiment until December when he was transferred to the GHI for acute mania. ${ }^{84}$

Keeping incapacitated soldiers with their units could prove dangerous, or even fatal. On the march from Shiloh to Memphis, Tennessee, it became apparent to comrades that Alexander

\footnotetext{
${ }^{83}$ Widow's pension for Sarah Boland (soldier James Boland) application 330809 and certificate 267889. National Archives, Washington, D.C.; Annual Report of the State of New York for the Year 1895. Registers of the First and Second Veteran Cavalry, First and Second Mounted Rifles, in the War of the Rebellion. Transmitted to the Legislature January 8, 1896 (Albany and New York: Wynkoop Hallenbeck Crawford Co., State Printers, 1896), 512. dmna.ny.gov/historic/reghist/civil/rosters/cavalry/1stMtdRiflesCW_Roster.pdf (January 28, 2015).

${ }^{84}$ Jonathan Rist, pension application 275209 and certificate 250220, widow (Samantha) application 357357 and certificate 326143. National Archives, Washington D.C.
} 
Anderson of the $1^{\text {st }}$ Illinois Artillery had become insane, so much so that a guard had to be placed on him because he was entirely incoherent and unconscious of his actions. When the regiment arrived at Memphis, Anderson slipped away from his regiment and ended up jumping out of the second story window of a business building. The resulting broken leg put Anderson in Overton General Hospital where on June 28, 1862 he killed himself with a pistol taken from a comrade's knapsack. ${ }^{85}$ Because Anderson's unit was on the march within the Confederacy after the Battle of Shiloh, it is likely they could not get their comrade to a Union asylum or the GHI. As a result, Anderson was placed in a general hospital to care for his physical wound, the broken leg, and was not under the scrutiny he would have been under for his mental state in an asylum.

The largest barrier to soldiers receiving treatment for mental trauma received during the war was the inability or unwillingness of army surgeons or asylum psychiatrists to connect war experiences to the insane soldiers being admitted to their hospitals. The transition from an optimistic, environmentally-based understanding of insanity to a focus on the hereditary, moral, and physical causes of mental illness before the war was strengthened and solidified during the war. While the Civil War presented a variety of cases in which soldiers were negatively affected by the physical and mental strain of soldiering, physicians and psychiatrists distanced themselves from examining the environment of warfare as causation and strengthened the theory of insanity as a physical disease. Asylum superintendent J. H. Worthington stated in his report for 1867 that "Insanity being a physical disease it is reasonable to seek for its relief and cure in such remedies as by their action on the physical organism are capable of removing the diseased condition." 86

\footnotetext{
${ }^{85}$ Father's pension (George Anderson; soldier Alexander Anderson) application 337140. National Archives, Washington, D.C.

${ }^{86}$ Fifty-First Annual Report on the State of the Asylum, for the Relief of Persons Deprived of the Use of Their Reason. (Philadelphia: Printed by William K. Bellows, 1868). Falk Library, University of Pittsburg Health Sciences Library, Collection Ms 9, Insane Hospital Reports, Volume II, page 13-16.
} 
Instead of dividing cases as purely mental or physical, as some had previously done, he argued that the distinction was merely nominal and that both medical and moral treatment worked towards the physical improvement of the patient. ${ }^{87}$

The 1865 report of Superintendent John P. Gray, overseeing the New York State Lunatic Asylum, was even more specific. He argued that symptoms of insanity "are but symptoms of recognized bodily disease — of a changed physical state. The mind cannot be sick or insane. These changes in the manner of thinking, in the feelings and actions, are significant and important to the physician only because they indicate the existence of bodily disease." 88 When looking at cases of headache, pain, dizziness, delusions, or changed habits, the physician should not concern himself with the visible indicators but focus on the physical conditions causing the outward symptoms. "In both cases," Gray concludes, "if the physical disease is removed, the symptoms disappear, and the operation of fixed laws may be perceived in all these manifestations. Insanity forms no exception. It is simply the result of physical disorder, and though originating from a variety of causes, always assumes one of several well recognized forms." ${ }^{89}$ Asylum physicians cautioned parents and teachers in the post-war period to prevent insanity in the next generation by attending to the bodily wellness of their children and students through diet, exercise, careful regulation of the emotions and passions, the development of both moral and intellectual powers to balance each other, and limitation of deep study in favor of physical exercise to promote a sound body. ${ }^{90}$

\footnotetext{
${ }^{87}$ Ibid.

${ }^{88}$ Twenty-Third Annual Report of the Managers of the State Lunatic Asylum, For the Year 1865 (Albany: C. Wendell, Printer, 1866). Falk Library, University of Pittsburg Health Sciences Library, Collection Ms 9, Insane Hospital Reports, Volume II, page 25.

${ }^{89}$ Ibid.

${ }^{90}$ Annual Report of the Trustees and Superintendent of the State Lunatic Hospital of Pennsylvania. (Harrisburg: Theo. F. Scheffer, Printer, 1866), 20. Pennsylvania State Archives, RG-23 Records of the Department of Public Welfare, Harrisburg State Hospital, Annual and Biennial Reports, 1851-1923, 1926-1928, 1934-1936, 1946-1958, 1969-1, Box 1.
} 
With the military and medical field focused on physical causation and symptoms of mental illness, it is not surprising that soldiers also connected their mental symptoms with physical causes. Illness and disease were also commonly pointed to by both physicians and soldiers to explain mental ailments and insanity. In some cases, overheating or fever could cause temporary or long-term insanity. When William Clark of the $64^{\text {th }}$ New York Infantry died of Typhoid Fever in 1862, both his pension file and the adjutant report note that he was placed on a transport ship insane from his illness. ${ }^{91}$ In the case of Royal Russell, a forced march between Suffolk and Blackwater caused him to become "exhausted by the heat and hard marching and broken down." 92 This exposure, according to his pension claim, led to his mental instability and long-term insanity.

Soldiers looked to overexposure to the elements as a cause for insanity in many cases. A second defined ailment often attached to soldiers who suffered from insanity or mental difficulty was "sunstroke." Some modern analysts have connected sunstroke to conditions such as "combat fatigue," however for Civil War physicians sunstroke was a purely physical ailment. ${ }^{93}$ The Medical and Surgical History of the War of the Rebellion states: "Fatigue was as much an element in the causation of these cases as exposure to the sun. In fact, the majority of the cases reported as sunstroke were the result of heat, over-exertion and an insufficient water-supply."94 For Civil War physicians, sunstroke was an ailment that came from hard labor or marching in the heat resulting from lack of hydration and the burden soldiers carried with them. The entry in the

\footnotetext{
${ }^{91}$ Mother's pension (soldier William M. Clark) application 20114, certificate 10451. National Archives, Washington, D.C.; Annual Report of the Adjutant-General of the State of New York. For the Year 1901. Registers of the Sixty-third, Sixty-fourth, Sixty-fifth, Sixty-sixth, Sixty-seventh and Sixty-eighth Regiments of Infantry. Transmitted to the Legislature January 7, 1902 (Albany, J.B. Lyon Company, State Printers, 1902), 233.

dmna.ny.gov/historic/reghist/civil/rosters/Infantry/64th_Infantry_CW_Roster.pdf (February 4, 2015).

${ }^{92}$ Royal Russell pension application 362910 and certificate 255037, widow pension application 785506 and certificate 565619. National Archives, Washington, D.C.

${ }^{93}$ Eric T. Dean, Jr., Shook Over Hell, 116-117, 128-131.

${ }^{94}$ The Medical and Surgical History of the War of the Rebellion, 854.
} 
Medical and Surgical History continues on to discuss the difficulties of a soldier cooling down due to the layers of the uniform and how the pack lay on his shoulders and back, preventing perspiration from properly cooling the body. Fatal cases were described as resulting from the heat affecting the brain, leading to fainting, convulsions, and coma. ${ }^{95}$

When testifying for a pension in 1887 while an inmate at an insane asylum in Utica, NY, William Gardiner stated that in 1865 he became insane, resulting "from a sunstroke received by me while engaged in battle in the battle of the Wilderness" in $1864 .{ }^{96}$ He remembered that he was treated for sunstroke in the regiment and confined to the guardhouse until he was sent to the GHI where he was treated for acute mania from February to June $1865 .{ }^{97}$ In the claim of one New York soldier, he declared that he had received a sunstroke due to the heat near Savage Station in June 1862 that caused injury to his head resulting in headaches and dizziness. A comrade testified for the pension file stating that the soldier "was prostrated with the heat and fell down in the ranks," after which he was sent to the hospital for several months. Five years after testifying for his pension claim, this soldier was admitted to Utica State Hospital “incoherent and fully controlled by delusions" including loss of memory, suspicion and fearing injury from friends, and "engaging in imaginary battles." The cause of insanity listed in his asylum file was listed as "Sun Stroke" and his pension was approved in 1890 for "vertigo, headache and insanity results of sunstroke." ${ }^{98}$ Another soldier admitted to Utica State Hospital, arrived voluntarily in 1884 asking for help with headaches, dizziness, and mental confusion resulting from a sunstroke in 1863 . The admitting staff noted that he suffered from insomnia,

\footnotetext{
95 The Medical and Surgical History of the War of the Rebellion, 854-857.

${ }^{96}$ William V. Gardiner, pension application 363852, certificate 1132728. National Archives, Washington, D.C.

${ }^{97}$ Ibid.

${ }^{98}$ Pension certificate 368040, National Archives, Washington, D.C.; New York State Archives, Utica State Hospital Patient Case Files, 1843-1898 (14231-96), Volume 70, Entry 3.
} 
delusions that everything was unclean and dirty, fear that he might injure someone during his bouts of melancholia, and that he was physically broken down and wept at trifling matters. He submitted a pension application in 1898 for "headache, dizziness, sunstroke, and rupture of right side + general debility" while still an inmate at Utica; the pension does not seem to have been granted. ${ }^{99}$

In the case of Michael Schwnek, $56^{\text {th }}$ New York Infantry, comrade Morris Downce testified that the soldier became insane at Morris Island, SC in October 1864 and "the first signs of insanity manifested by him were tearing up his blanket and clothing." ${ }^{100}$ Downce had to take over Schwnek's watch after he was placed in confinement to prevent him doing any damage before being sent to an asylum. ${ }^{101}$ Chauncey Avery also testified that Schwenk became insane at Morris Island in 1864, noting that he "got up one night naked, took his gun and went to some regiment...lying close by our regiment, intending to kill somebody there." ${ }^{102}$ Neither deposition or his entry in the adjutant report mentions sunstroke, but the Surgeon's Certificate from 1887 and a letter from the Bureau of Pensions both attribute the insanity to sunstroke as there were several men in the regiment falling to the heat at the same time Schwenk started to exhibit symptoms. ${ }^{103}$ It is very possible that some cases of service-related insanity were pure cases of sunstroke where overexposure to heat and hard labor caused mental symptoms similar to today's diagnosis of heat stroke. However, it is also very likely that "sunstroke" served as a blanket term

\footnotetext{
${ }^{99}$ Pension application 1176331, National Archives, Washington, D.C.; New York State Archives, Utica State Hospital Patient Case Files, 1843-1898 (14231-96), Volume 62, Entry 1.

${ }^{100}$ Michael Schwenk, pension application 414083, certificate 668845, National Archives, Washington, D.C.

101 Ibid.

102 Ibid.

${ }^{103}$ Michael Schwenk, pension application 414083, certificate 668845, National Archives, Washington, D.C.; Annual Report of the Adjutant-General of the State of New York. For the Year 1900. Registers of the Fifty-first, Fiftysecond, Fifty-third, Fifty-fourth, Fifty-fifth and Fifty-sixth Regiments of Infantry. Transmitted to the Legislature January 9, 1901 (Albany: James B. Lyon, State Printer, 1901), 1173. dmna.ny.gov/historic/reghist/civil/rosters/Infantry/56th_Infantry_CW_Roster.pdf (February 4, 2015).
} 
that allowed soldier and medical personnel to legitimize multiple forms of mental trauma by relating it to defined physical ailments.

Beyond sunstroke or fever, other illnesses were blamed for insanity in soldiers. When a soldier who had gone home on furlough for illness returned to his Pennsylvania regiment in May 1862, comrades noticed something wrong with his behavior. In testimony for this soldier's pension, a comrade remembered that he "wandered off from the company into the enemies lines he was taken prisoner by the enemy and was afterwards paroled by the Rebs and got back within the Union lines" after which he was sent to an asylum at Alexandria, discharged, and sent home to another hospital. ${ }^{104}$ An Ohio soldier admitted to the Dayton State Hospital in December 1864 for mania caused by "Exposure in U.S.A." reportedly suffered from chronic diarrhea for months before entering a regimental hospital in April 1864 near Mountsville, Alabama. According to testimony from one of his officers, when in the hospital said soldier became deranged, requiring a constant watch, and escaped, apparently running all the way to Nashville, TN where he was taken into a General Hospital. From there it appears he was taken to the asylum in Dayton then to the GHI, where he died in March 1887 from Acute Penitonitis. ${ }^{105}$ And, in the case of a young Ohio soldier who was admitted into Columbus State Hospital in August 1865 at the age of 19 after being sent home from Camp Dennison, $\mathrm{OH}$, his pension file claimed that he was taken sick while on picket duty in inclement weather and became partially insane, so much so that he did not even recognize his father when the man arrived at Camp Dennison to take him home. ${ }^{106}$

\footnotetext{
${ }^{104}$ Pension application 101594. National Archives, Washington, D.C.

105 Pension application 62913, certificate 81106, Widow's pension application 355017, certificate 258543. National Archives, Washington, D.C.; Ohio Historical Society, Dayton State Hospital, Register of Male and Female Patients, 1855-1902 (call \#: State Archives Series 153) (BV8897), 26.

${ }^{106}$ Pension application 113050. National Archives, Washington, D.C.; Ohio Historical Society, Columbus State Hospital, Admission Books, 1838-1868 (call \#: State Archives Series 896) (BV7215), 164.
} 
Soldiers that may have experienced stress reactions or trauma often framed their symptoms in the context of physical ailments. Doing so legitimated their ailments and placed their illness within a physical context understood by both physicians and soldiers. Testimony from Hardison Parsons of the $36^{\text {th }}$ Ohio Infantry about a messmate in Company A claimed that after Chickamauga, "on the retreat from the fight claimant became very excited and had a wild look out his eye and as soon as we reached Chattanooga he was put in a hospital." ${ }^{107}$ Parsons remembered that his friend rejoined the company a few times over the war, but was seized with this excitement again and returned to the hospital each time. Robert Israel of the same company testified that the soldier's head seemed to trouble him most in the heat and his eyes would get glassy and "wild." Israel testified that "[w] henever we would go out on scout or forage march, he would thrash around on the bunk all night, talking in his sleep and fighting rebels, and seemed to be laboring under great metal excitement." ${ }^{108}$ Israel remembered pulling him down from the bunk and quieting him in his sleep and pouring cold water over his head when he suffered headaches. While the soldier did spend some time in Columbus State Hospital in 1865, after family noticed he "talked wildly and had an odd look out of his eyes," the claimant himself remembered the incident differently. In his own deposition for his pension file, the soldier remembered that after a hard scout in 1861, he was "taken sick with what I thought was typhoid fever but Genl Devoe says I became wild—I had got chilled and caught cold on this scout and the fever set in over me." ${ }^{109}$ His testimony mainly focused on symptoms of illness and the couple of wounds he received in the service, receiving his pension for "injury to head and resulting

\footnotetext{
${ }^{107}$ Pension application 404814 and certificate 565801, Widow's application 958037 and certificate 718048 . National Archives, Washington, D.C.; Ohio Historical Society, Columbus State Hospital, Admission Books, 1838-1868 (call \#: State Archives Series 896) (BV7215), 158.

${ }^{108}$ Ibid.

${ }^{109}$ Ibid.
} 
impaired intellect and injury of left side and hip."110 The symptoms of this soldier seemed to originate in the retreat from Chickamauga and evidence trauma resulting from combat experiences, including nightmares at night and incidents of "excitement" during the day.

However, both the claimant and his witnesses connected his ailments to either heat or illness because physical causation was both legitimate and comprehendible.

There were definite cases where physical wounds or illness did cause trauma to the brain and mental symptoms in a soldier. In many other cases, however, it is possible that symptoms of trauma were related to physical ailments due to the contemporary medical and cultural understandings of how the body and mind functioned. Because soldiers did not recognize psychological trauma they searched for ways to understand their experiences and symptoms. Soldiers understood physical ailments, such as disease or reacting to exposure to the elements, and often connected mental symptoms to these more recognizable conditions. In addition, soldiers operating under cultural and social expectations that demanded courage and bravery in the line of duty believed that a physical condition that affected their brain was more honorable than a mental condition that led to insanity or instability.

A focus on physical causation and symptoms in insane soldiers and a lack of knowledge for some army physicians, in addition to the fears of malingering and the necessity of keeping men on the front lines led to inconsistent and incomplete treatment options for soldiers suffering along the spectrum of trauma during the Civil War. Army surgeons felt the pressure of keeping men on the front lines to fight, and consequently were very skeptical of soldiers suffering ailments that showed no recognizable physical symptoms. When soldiers were recognized as

\footnotetext{
${ }^{110}$ Pension application 404814 and certificate 565801, Widow's application 958037 and certificate 718048 . National Archives, Washington, D.C.; Ohio Historical Society, Columbus State Hospital, Admission Books, 1838-1868 (call \#: State Archives Series 896) (BV7215), 158.
} 
being insane or incapacitated, the Union army and northern asylum physicians believed insanity to be a result of moral or physical weakness and these soldiers were treated with that in mind. Without a concrete definition of trauma that connected wartime trauma to insanity and comprehensive treatment, official treatment options were limited for Civil War soldiers and they had to find ways to cope with and manage their wartime experiences on their own and with close comrades. As a result, soldiers built a coping culture based on their civilian experiences to manage and survive their time in the army. 


\section{Chapter Three:}

"I take great pains to take care of myself":

The "Unofficial" Coping Strategies of Union Soldiers

In February 1862, an article entitled "Affecting Case of Insanity" was published in the Wisconsin Patriot. Written by a Lieutenant Colonel Hawley, it related the unfortunate case of one of his men, referred to as "Dolph," who received word that his wife, two children, and sister had all died of diphtheria. After hearing this news "Dolph" seemingly went insane, holding a "baby" of dead moss and speaking to the loved ones he had just lost. Lt. Col. Hawley determined that the soldier was no longer fit for service and should be sent home. In the meantime, he ordered four men to watch over their crazed comrade and told them to remove all guns and bayonets from the man's presence, noting that the "men take as good care of him as they can." While describing this "most affecting case of insanity" the officer concluded his account with the statement, "We hope his insanity is caused partly by fever, and if we can get him quietly sick with that, perhaps he will come out all right. If not, I'll see that he goes straight to the insane retreat at Hartford..."1

This case illustrates the intersection of official and unofficial responses to insanity in soldiers. Lt. Col. Hawley's comment about getting the soldier "quietly sick" with fever acknowledges that a physical causation of insanity would be better received by both the military and those at home. Lt. Col. Hawley knew that "Dolph's" insanity was not caused by fever, but by the stress of his loved one's deaths, and he ordered "Dolph's" comrades to take care of him until they could get him sent home, either to family or to an asylum. While the official channels of treatment would look more favorably on a case of insanity caused by physical illness, these

\footnotetext{
1 "Affecting Case of Insanity - a Soldier Crazed by the Loss of His Wife, Two Children, and Sister," Wisconsin Patriot, February 15, 1862. America's Historical Newspapers.
} 
soldiers knew the true case of "Dolph's" symptoms and moved to help him in their own way. As soldiers faced, and sometimes succumbed to the stress of war, they had to develop their own methods of coping outside the treatments offered by the military and asylums.

In Kathryn Shively Meier's work Nature's Civil War, she argues that soldiers relied on methods of "self-care" to remain healthy and attend to their basic needs. While the army's medical department provided care for the ill and wounded and the commissary provided food and other necessities, Meier argues that these were insufficient to care for soldiers completely and that men found their own methods of care based on the knowledge and experiences they held from their civilian lives. Soldiers understood that there was a relationship between the environment and their health and found their own self-care techniques more effective than those provided by the official system. Meier's work centers on caring for physical health—bathing, keeping clothes clean, finding shelter, foraging for clean water and food to supplement their diet, and caring for ill family members and comrades outside of the hospital—but this idea of "selfcare" pertains to mental health as well. ${ }^{2}$ Charles F. Stinson of the $13^{\text {th }}$ New Hampshire wrote to his mother on December 17, 1862, after the Battle of Fredericksburg, "I never should have thought I could have gone through what I have. If I get back alive it will be a good thing for me. I take great pains to take care of myself that is as much as possible for this kind of life." ${ }^{3}$ Soldiers had to find ways to cope mentally with the experience of soldiering in order to stay in ranks and survive the war without becoming a psychological casualty.

When Union soldiers went to war they packed up the gear they would need to fight: clothing, supplies, weapons, ammunition, and reminders of home. Soldiers also unconsciously

\footnotetext{
${ }^{2}$ Kathryn Shively Meier, Nature's Civil War: Common Soldiers and the Environment in 1862 Virginia (Chapel Hill: The University of North Carolina Press, 2013), 2-5, 101-123.

${ }^{3}$ Charles F. Stinson to mother, Camp near Falmouth, VA, December 17, 1862. Fredericksburg \& Spotsylvania NMP Collections, Maine and New Hampshire Manuscripts USAMHI, Volume 107.
} 
packed a set of coping strategies to support them through the ordeal they were about to face.

These coping techniques helped soldiers survive the mental trauma of the Civil War and allowed them to understand and frame their wartime experiences within comfortable and recognizable limits. These concepts would not have been isolated for Civil War soldiers; instead, soldiers drew upon multiple concepts simultaneously, utilizing elements of each to match the situations in which they found themselves. Soldiers utilized religion, devotion to cause, cultural norms of death, ideas of courage and masculinity, ties to family and comrades, camp amusements, alcohol, training, dehumanizing the enemy and death, and desertion to cope with their wartime experiences. While these elements have been studied separately as parts of the soldier's daily life, they are also coping techniques men relied on to maintain their mental health and morale.

As seen in "Dolph's" case at the opening of this chapter, a soldier's relationship to others was crucial to their management of wartime experiences, both those in immediate proximity and long-distance. "I assure myself that I cannot be court martialed for deserting my post in the presence of the enemy, and then take a rapid flight (mentally)," wrote George A. Hitchcock on guard in late October 1863. "With one bound I have crossed the Holston, Clinch, Cumberland, Alleghany, Blue Ridge and many other lofty ranges and deep rivers, and once more I am in my quiet boyhood home nestling among the hills of New England." In his mental image his parents and siblings sat far away from the war and the army, in contrast to the military scenes around him. He daydreamed of home until his guard was relieved and then "the big nineteen year old baby lies down to dream out the home pictures for four hours when the task is again taken up."4 For Civil War soldiers, family and connections to home were crucial in coping with the Civil War, both as an emotional support system and economic supply system that provided soldiers

\footnotetext{
${ }^{4}$ Ronald Watson, ed., From Ashby to Andersonville: The Civil War Diary and Reminiscences of Private George A. Hitchcock, $21^{\text {st }}$ Massachusetts Infantry (Campbell, CA: Savas Publishing Company, 1997), 144.
} 
with comforts and necessities. In addition, as volunteer soldiers, Civil War soldiers never fully gave up their civilian identities and keeping that connection to their pre-war lives helped ground their experiences and give them something to attain in the future, returning home after completing their duty to the nation.

These men were anxious to maintain connections with family at home to help them bear the hardships of their military life and resist the new temptations they encountered. James McPherson claims, "without a firm base of support in the homes and communities from which these citizen soldiers came, their morale would have crumbled." 5 The most common way soldiers remained connected to home was through writing letters, and mail call was often the highlight of a soldier's day if they received news from home. "Letters are ever the nearest things to our actual presence," wrote Lieutenant Colonel Richard S. Thompson, "and to a soldier they are invaluable." ${ }^{6}$ At the height of the war about 45,000 letters passed through Washington, D.C. daily from northern communities to the armies, and the same number traveled the other way. Twice that number passed through Louisville, KY for the western armies. ${ }^{7}$ Letter writing held double importance; not only was it the primary way for soldiers to maintain connections to home, sitting and writing correspondence also helped soldiers amuse themselves during the long days in camp and express sentiments about the war to close loved ones that they might not share with their messmates. Many soldiers wrote about the importance of this correspondence and chastised friends and family members who were not writing often enough. Communication between soldiers and civilians was an important support system; soldiers often wrote about how

\footnotetext{
${ }^{5}$ James M. McPherson, For Cause and Comrades: Why Men Fought in the Civil War (New York: Oxford University Press, 1997), 131.

${ }^{6}$ Gerry Harder Poriss and Ralph G. Poriss, While My Country is in Danger: The Life and Letters of Lieutenant Colonel Richard S. Thompson, Twelfth New Jersey Volunteers (Hamilton, NY: Edmonston Publishing Inc., 1994), 112.

${ }^{7}$ James I. Robertson, Jr., Soldiers Blue and Gray (Columbia: University of South Carolina Press, 1998), 102-109.
} 
thinking about home and family sustained them through their experiences. When writing to his aunt and uncle, Homer A. Plimpton of the $39^{\text {th }}$ Illinois Infantry asked, "Did you know that often when undergoing some of the severe hardships \& exposed to the imminent dangers incident to a soldier's life we are many times encouraged by thoughts of our friends at home — cheered by the thought that they may even now be thinking of us?" friends at home fail to appreciate the importance attached to this duty of writing often \& freely to the soldier."

Battle was a hard experience, but it took more reassurance to stay in the army day after day. To stay in the ranks, soldiers looked for continual approval from home. ${ }^{10}$ For O. W. Norton, the excitement of military life had passed by April 1862, causing him to look forward to the time he could settle down to farming and find a woman to marry, and William Beynon Phillips exclaimed, "[w]hat a blessing it would be ... to go around and about, to enjoy your society and caresses, without having to be disturbed by Rebel shot \& shell, to feel certain when I lay down to rest that I am safe from harm as far as lead and iron are concerned." ${ }^{11}$ As much as soldiers longed for the peaceful blessings of the civilian life they had left behind, those same blessings kept them fighting. "I can only think of home," wrote a man from Indiana, "[a]nd but for those at home I might feel less like serving my country."12 Support from home kept soldiers going, not just as an ideal to which soldiers longed to return or the families that were waiting for them, but also as a reminder of what many of these men felt they were fighting for. Men frequently expressed delight on receiving letters, asked for or discussed news from home, begged for paper

\footnotetext{
${ }^{8}$ Homer A. Plimpton to uncle and aunt, September 16, 1864. SoldierStudies.org, accessed November 11, 2011.

9 Ibid.

${ }^{10}$ Eric T. Dean, Jr., Shook Over Hell: Post-Traumatic Stress, Vietnam, and The Civil War (Cambridge, MA: Harvard University Press, 1997), 92-93.

${ }^{11}$ O. W. Norton to "Sister L," April 21, 1862. SoldierStudies.org, accessed November 12, 2011; William Beynon Phillips to Annie, July 20, 1864. SoldierStudies.org, accessed November 12, 2011.

12 James M. McPherson, For Cause and Comrades, 131.
} 
and stamps so they could keep up the correspondence, and conveyed their desires to be back with loved ones again once they completed their duty. Soldiers relied on these connections far more than grand ideas, revealed through language that expressed the need and longing for basic connections with loved ones.

The reliance on family and home for support also manifested itself in another way. As citizen-soldiers, Union men maintained ties to their civilian identities, cultural beliefs, and social norms. Fighting to defend one's home meant that connections to family and the civilian life left behind were important to Civil War soldiers. In one very real way the war was an extension of the home community as companies and regiments were often recruited within the same social organizations or towns, meaning many soldiers knew each other from civilian life. Those who remained at home could encourage enlistment or put pressure on soldiers to do their duty well; at the same time they worried that camp life would corrupt their loved ones. Family members urged men going off to war to remain pure and reject moral degeneration, and initially soldiers saw the war as an extension of their home life where the same values and behavior applied. ${ }^{13}$ Soldiers' "self-care" techniques reflected their connection to home and their understandings of the world from civilian life. With "official" treatment options within the military and medical fields limited by the belief that insanity was not connected to traumatic wartime experiences, soldiers used concepts from their civilian lives to cope.

One of the most prevalent cultural concepts used by Civil War soldiers to cope with their wartime experiences was religion and ideas of death and the afterlife. Writing in the midst of the Vicksburg Campaign in 1863, Captain Henry Martin Kellogg of the $33^{\text {rd }}$ Illinois Volunteer

\footnotetext{
${ }^{13}$ Reid Mitchell, The Vacant Chair: The Northern Soldier Leaves Home (New York: Oxford University Press, 1993), 11-15, 21-24, 72-87, 89-100; Gerald F. Linderman, Embattled Courage: The Experience of Combat in the American Civil War (New York: The Free Press, 1987), 36, 73-78, 83-95; Earl J. Hess, The Union Soldier in Battle: Enduring The Ordeal of Combat (Lawrence, KS: The University Press of Kansas, 1997), 122-125, 154.
} 
Infantry reflected deeply in the role faith played in his wartime experiences as a soldier: "The sun rises beautiful as ever, but some of us behold its light for the last time, perhaps I do, God only knows. In him is my trust." 14 Throughout the hard Vicksburg Campaign, Kellogg wrote often of his reliance on God, writing to his wife to "Trust in God he is good \& will do right." 15 On the morning of the Battle of Champion Hills, Kellogg wrote in his diary "To his care I commit myself, he doeth all things well. If it be thy will O God! spare me to support and cheer my wife and boy and comfort my aged parents, but if thou has ordained otherwise . . help all to say thy will be done."16 On coming through the day's fighting unhurt, he settled under an oak tree to rest that afternoon and wrote that he had just given thanks to "the kind Father who has preserved me safe from harm." 17 The themes of faith and heavenly protection are woven deeply within Kellogg's writing, as are emerging images of a heavenly afterlife. Reflecting on the coming fighting at Champion Hills, about four hours before his musings under the oak tree, he wrote in his diary, "Father and mother, if we meet no more on earth we shall soon meet and may it be in heaven." 18 Religious faith, reliance on heavenly protection, and the hope for peace and reunion in the afterlife were all central to many soldiers' ability to accept and cope with the stress of combat and camp life. But, while this faith was deeply rooted in soldiers' civilian experiences with religion, the war forced soldiers to adapt their cultural understandings of death and faith to match their coping needs.

Religion, Christianity in most cases, provided guidelines for proper behavior and faith helped sustain morale for many soldiers in their new situation of army life. In letters, a wide

\footnotetext{
${ }^{14}$ Michael R. Cunningham, "Follow me to victory or death": The diaries and letter of Captain Henry Martin Kellogg, 33 ${ }^{\text {rd }}$ Illinois Volunteer Infantry (1993), 29.

${ }^{15}$ Henry C. Kellogg to wife, May 6, 1863. SoldierStudies.org, accessed November 19, 2011.

${ }^{16}$ Michael R. Cunningham, "Follow me to victory or death," 33.

${ }^{17}$ Michael R. Cunningham, "Follow me to victory or death,” 33-34.

${ }^{18}$ Michael R. Cunningham, "Follow me to victory or death," 33.
} 
range of soldiers made references to God. These could be continued expressions of devotion throughout military service or simple declarations of gratitude and hope for protection when facing battle. Although complete numbers are not available, scholars have argued that devout Christians were the minority in Civil War armies. However, whether or not a man claimed to be religious, the Civil War soldier was a product of a time when religion was quickly changing and in the public eye. The American Revolution inspired changes in religious thought as denominations tried to adjust to the new national culture, but the focus on theology grew rapidly in the 1820s. There were more divergent voices and challenges to traditional methods, and the Second Great Awakening brought about an increase in revivalism, evangelicalism, and a new level of participation in religious discourse. Through the sectional crisis theology remained part of the national dialogue, and religious antagonism grew fierce as both Union men and Confederates declared their nation to be the "true Christian republic worthy of divine assistance." ${ }^{19}$ For the soldiers there was plenty of encouragement for spiritual reflection in camp. Christian men who enlisted attempted to continue their religious dedication, gathering to sing hymns and attend prayer meetings, services, and Sunday school sessions conducted by chaplains. Organizations such as the American Bible Society, the American Tract Society, and the United States Christian Commission supplied soldiers with testaments and evangelical tracts warning against the dangers of swearing, drinking, and gambling. Faith in God provided soldiers with personal psychological support as well as institutional support of country and cause. ${ }^{20}$

\footnotetext{
${ }^{19}$ David Rolfs, No Peace for the Wicked: Northern Protestant Soldiers and the American Civil War (Knoxville: The University of Tennessee Press, 2009), 5.

${ }^{20}$ Mark A. Noll, America's God: From Jonathan Edwards to Abraham Lincoln (New York: Oxford University Press, 2002), 292-294, 368-369; Daniel Walker Howe, What Hath God Wrought: The Transformation of America, 1815-1848 (New York: Oxford University Press, 2007), 164-202, 285-327; David Rolfs, No Peace for the Wicked, 4-5, 21; George C. Rable, God's Almost Chosen People: A Religious History of the American Civil War (Chapel Hill: The University of North Carolina Press, 2010), 127-129, 132-133; James M. McPherson, For Cause and Comrades, 63; See also, David W. Rolfs, "'No Nearer Heaver Now But Rather Farther Off': The Religious Compromises and Conflicts of Northern Soldiers," in The View from the Ground: Experiences of Civil War Soldiers,
} 
Spiritual tracts also included messages of salvation important to men who now had to face daily the possibility of their own deaths. Devout soldiers who made their peace with God and relied on Him for strength felt prepared to face the challenges ahead. Many agreed that Christians made the best soldiers due to their calm and steady nature in battle; their fear was of God, not of man. Other soldiers, impressed by expressions of peace by Christian soldiers on the battlefield and on the deathbed, and faced with the greater possibility of their own deaths, found in the war their chance to convert. "I am trying to live a better man than I was at home," wrote a soldier in the $114^{\text {th }}$ Ohio, "I see the necessity of living a Christian here where thy ar dropping all around you." ${ }^{21}$ The horrific nature of battle encouraged prayer and an increased interest or renewed commitment to God. Writing after surviving the Battle of Cold Harbor, a member of the $4^{\text {th }}$ Delaware wrote: "In that dreadful place I resolved to forsake my evil ways and to serve god." 22 Survival and close calls were particularly inspiring. "It was pretty close dogging for me to have a shell pass between my arm and side, and I think none but a Divine hand directed it," wrote Private Moses A. Parker of the $3^{\text {rd }}$ Vermont. ${ }^{23}$ "[T] $]$ hank God I am still alive, after many hair-breadth escapes," wrote infantryman William Collins. "One ball passed through my cap, another through the skirt of my coat—but not a scratch on my skin."24

Religious revivals swept the armies beginning in 1862 and continued through the rest of the war. In her work on revivals in the Confederacy, Drew Gilpin Faust notes that while soldiers enthusiastically participated in revivals, this did not occur in the civilian population. This

\footnotetext{
edited by Aaron Sheehan-Dean (Lexington, KY: The University Press of Kentucky, 2007), 121-144; Kent T. Dollar, "'Strangers in a Strange Land': Christian Soldiers in the Early Months of the Civil War," in The View from the Ground: Experiences of Civil War Soldiers, edited by Aaron Sheehan-Dean (Lexington, KY: The University Press of Kentucky, 2007), 145-169.

${ }^{21}$ James M. McPherson, For Cause and Comrades, 64.

${ }^{22}$ James M. McPherson, For Cause and Comrades, 64.

${ }^{23}$ Steven E. Woodworth, While God is Marching On: The Religious World of Civil War Soldiers (Lawrence, KS: University Press of Kansas, 2001), 193.

${ }^{24}$ William H. Collins to wife, July 23, 1861. SoldierStudies.org, accessed November 29, 2011.
} 
suggests that religion was more important to the common soldiers because of the trials and stresses of life in the armies. Chaplains and evangelicals actively encouraged revivalism in the armies, happy to find more converts, thus high rates of religion within the Southern army might be a result of their efforts and the distribution of bibles and tracts which soldiers read either out of devotion or to fight the monotony of camp. ${ }^{25}$ More likely, many soldiers accepted these revivals because the reality of the battlefield drove them to find comfort in faith. Of course, not every soldier was swept up in the movement and skepticism continued, along with the camp vices of gambling, drinking, swearing, and sexual immorality. For many soldiers, however, faith provided them consolation, understanding, and the ability to overcome the natural fear of death. ${ }^{26}$ The most fervent expressions of religious faith were made in gratitude for surviving a battle. Soldiers who believed in God's will and providence believed these responsible for sparing them in whatever engagement they had just survived. "Our good father led me safe through," wrote a soldier fighting near Mobile, Alabama, "\& know that it was through his kind providence that I was spared." 27 The language varied, from a simple "[t]hrough the protection of the Almighty I have come off safe" after the Battle of Antietam to direct biblical references_ - "He who numbers the very hairs of our head and notes even the fall of the sparrow shielded me in the hour when bullets rained like hail around me,"- - but the message was the same. ${ }^{28}$ Soldiers

\footnotetext{
${ }^{25}$ Drew Gilpin Faust, "Christian Soldiers: The Meanings of Revivalism in the Confederate Army," The Journal of Southern History 53, no. 1 (Feb. 1987): 64-67. In her article Faust argues that while revivals occurred in the Northern armies, the higher stresses placed on the Confederate soldier led to more religious uniformity in the Southern armies. Reid Mitchell argues against her in his chapter "Christian Soldiers? Perfecting the Confederacy" in Religion and the American Civil War, edited by Randall M. Miller, Harry S. Stout, and Charles Reagan Wilson (Oxford: Oxford University Press, 1998), 297-309.

${ }^{26}$ George C. Rable, God's Almost Chosen People, 8-9, 132-133, 139-144, 162; Steven E. Woodworth, While God is Marching On, 194-195, 207-208, 215-216.

${ }^{27}$ Joseph Prutzman to wife and children, May 23, 1865. SoldierStudies.org, accessed November 12, 2011.

${ }^{28}$ William Gilfillan Gavin, Infantryman Pettit: The Civil War Letters of Corporal Frederick Pettit, Late of Company C, 100 th Pennsylvania Veteran Volunteer Infantry Regiment "The Roundheads," 1862-1864 (Shippensburg, PA: White Mane Publishing Company, Inc., 1990), 14; Steven E. Woodworth, While God is Marching On, 193.
} 
believed that God's protection kept them safe. "Any man who escaped with his life from that field [Gettysburg] although badly wounded may consider himself fortunate and preserved by some power above human." ${ }^{29}$ Even outside the immediate effects of battle soldiers praised God for their survival. Reflecting on the anniversary of one year in the service, Cyrus F. Boyd thanked God for his preservation and for both the enjoyments and hardships he had faced during that time. ${ }^{30}$

Christian soldiers placed great weight on God's will, the belief in providence and divine sovereignty that resulted from Protestantism, Puritanism, and the Great Awakening. Lewis O. Saum states that providence, the view that God directly or indirectly controlled all things, was the most pervasive and fundamental theme in pre-Civil War writings. The war itself, and all the death and destruction that came with it, was perceived to be part of a larger plan and a higher purpose. Soldiers went into battle believing that God's will would be evident in the outcome of the contest and the casualties; this provided a kind of relief to soldiers who believed that their actions would not result in their demise. ${ }^{31}$ This matches the coping behaviors of denial and fatalism; in the first soldiers convince themselves that nothing can hurt them, and the second refers to the feeling that there is nothing a soldier can do to prevent injury or death so they need to just move forward into battle. ${ }^{32}$ Shirking would not protect them and going forward into danger would not harm them because the ultimate decision of life and death lay with God. Even the belief in providence and God's will did not stop soldiers from turning seriously to prayer

\footnotetext{
${ }^{29}$ J. Henry Blakeman, July 21, 1863. SoldierStudies.org, accessed November 29, 2011. The author was writing from Jarvis Hosptial in Baltimore, thus the comment about being thankful "although badly wounded."

${ }^{30}$ Mildred Throne, ed. The Civil War Diary of Cyrus F. Boyd, Fifteenth Iowa Infantry, 1861-1863 (Baton Rouge: Louisiana State University Press, 1953), 80.

${ }^{31}$ George C. Rable, God's Almost Chosen People, 1-2, 9; Lewis O. Saum, The Popular Mood of Pre-Civil War America (Westport, CT: Greenwood Press, 1980), 3; David Rolfs, No Peace for the Wicked, 106-108.

${ }^{32}$ Richard Holmes, Acts of War: The Behavior of Men in Battle (New York: The Free Press, 1985), 233-235, $240-$ 241.
} 
before battle, searching for strength and a reassurance of faith. Praying before and even during battle, some soldiers found a sense of peace and forgot the fear of death. "I feel very calm," wrote Elisha Hunt Rhodes in early May 1864, just before the campaign began, "trusting in God that his protecting care will be over me. While I do not feel that I am more safe than others, yet I have a firm reliance upon my Heavenly Father and am willing to leave all to him." 33 This reliance on heavenly protection gave some soldiers the strength to step into the world of battle. ${ }^{34}$ God's support, soldiers believed, also extended to the Union cause as well, an idea promoted by military authorities through days of thanksgiving and prayer. Meant to continue God's favor, days of thanksgiving expressed joy in success and days of prayer followed failure. God's support and the belief that putting down a rebellion that was wicked and wrong was a just cause spurred some soldiers to continue fighting, and they did not want anything to jeopardize that favor. ${ }^{35}$ For example, fighting on the Sabbath concerned some soldiers. "I hope our army will not attack the enemy to-morrow," wrote Cyrus F. Boyd during the advance on Corinth, Mississippi, "as it is Sunday and our men seem to have a dread of going into battle on that day unless it is defence [sic]." ${ }^{36}$ These wary soldiers had good cause to feel that way: "The terrible Sunday at Pittsburgh [Shiloh] is pointed to and the reason given that the enemy was defeated because they commenced the fight on that day." ${ }^{37}$ Reflecting in 1865 on orders to fight on Sunday, June 14, 1863, William Jones echoed this protest: "Public attention had already been several times called to the fact that those who made the attack on that day [Sunday], were almost

\footnotetext{
${ }^{33}$ Steven E. Woodworth, While God is Marching On, 238.

${ }^{34}$ George C. Rable, God's Almost Chosen People, 160-161.

${ }^{35}$ Steven E. Woodworth, While God is Marching On, 99-100; Harry Stout, Upon the Altar of the Nation: A Moral History of the American Civil War (New York: Viking, 2006), xvii-xvi, 16, 38, 42.

${ }^{36}$ Mildred Throne, ed., The Civil War Diary of Cyrus F. Boyd, 47.

${ }^{37}$ Ibid.
} 
always unsuccessful, and in this case it seemed so unnecessary." 38 Jones was not surprised that such decisions created dissent among the ranks, for almost every man had been taught from an early age to revere the Sabbath. But they must go forward, he concluded, for "it is the soldier's duty to obey implicitly and faithfully."39

Religion meshed with a devotion to the national cause because it was important for soldiers to consider their cause as more "moral" or "holy" than that of the enemy. A sense of duty was key, and in some cases the relationship between God and country became so close that they almost merged together. Civic religion emphasized national virtue, purpose, and destiny, and boasted of a strong relationship with God. William Wheeler wrote in late 1862 that "so allimportant are the virtues of courage and firmness out here, that one has a tendency to forget that any other virtues are worth practicing; but I have succeeded in keeping alive one more, Faithfaith in the soundness of Northern hearts, and in the honesty of the President; faith in the approval of the Ruler above, and in the consequent success of our cause." ${ }^{40}$ Soldiers were willing to put duty to country before duty to family because of their devotion to their nation as a Christian republic. Americans, George Rable argues, believed they were God's chosen people who were carrying out His mission. Some soldiers even believed that by fighting and dying for the cause of their country, they would be guaranteed admission into heaven, bypassing the traditional Christian path of obtaining salvation through faith in Jesus Christ. Such consideration

\footnotetext{
${ }^{38}$ William E. Jones, The Military History of the One Hundred and Sixty-first New York Volunteers, Infantry, from August 15 th 1862 to October 17, 1865 (1865). Army Heritage and Education Center, Carlisle, PA. U.S. Army Military History Research Collection.

${ }^{39}$ Ibid.

${ }^{40}$ William Wheeler, "Letter from William Wheeler to Aunt E, November 25, 1862," Letters of William Wheeler of the Class of 1855, Y.C. (1875), 366. American Civil War: Letters and Diaries, accessed December 1, 2011, (Wheele:L1913-88).
} 
not only provided comfort for religious soldiers about their status after death, less religious

soldiers leaned on their devotion to a "moral" cause to fight and endure their experiences. ${ }^{41}$

Central to the use of faith for coping was using it to justify the deaths necessary on the

battlefield and provide comfort to the soldiers facing that possibility. The Civil War changed

America's views on the afterlife and produced a new version of heaven that emerged from the

conflict. Before the war heaven was a vague place where people could be with God, but the

emphasis was on the final moments of life surrounded by family who could assess their death

and thus their condition after life. Nineteenth-century Americans believed in the idea of a "good

death," or a ritualized understanding of how to die and how to witness the deaths of loved ones. ${ }^{42}$

Transferred from Europe to America, by the nineteenth century the cultural practices of the

\footnotetext{
${ }^{41}$ Steven E. Woodworth, While God is Marching On, 105-107; George C. Rable, God's Almost Chosen People, 3; David Rolfs, No Peace for the Wicked, 46-53; Dave Grossman, Lt. Col., On Killing: The Psychological Cost of Learning to Kill in War and Society (New York: Back Bay Books, 2009), 164-168.

${ }^{42}$ Mark Schantz argues that nineteenth-century America was a "death-embracing" society in which cultural scripts determined how people behaved on their deathbed and how they imagined death and the afterlife. Similarly, Drew Faust argues that the experience of death was a unifying experience for the American nation. Lewis Saum saw antebellum America as a culture focused on death simply because that was the reality of life. Mortality rates produced a constant discourse on the subject, a steady consciousness of the possibility of death led to fatalism and caution, and the lack of professional services for handling the dead and dying resulted in a widespread intimacy with the dead. The experiences of the antebellum age and the ways Americans engaged with death before the Civil War certainly had an impact on experiencing death during the war. To say, as Schantz does, that the "very pervasiveness of death in antebellum America trained up an entire generation to see it not as something to be avoided, but as the inevitable destiny of humanity"- thus making the Civil War generation more willing to accept war and death on the battlefield - may be going a bit too far, but this grounding certainly provided soldiers with a way to frame their wartime experiences. In addition to experiencing death within one's circle of family and friends, Schantz argues that antebellum Americans also encountered death in daily life through literature, art, cemeteries, and ideas of heaven. For example, poetry in the 1840 s and 1850 s valorized death, especially massacres and slaughters, and the Greek revival re-introduced elements of martial tradition and heroic death. The concept of "heroic death" claimed that it was glorious for young men to die in battle, thus cheating the aging process. These brave young men would then be memorialized for eternity in the rise of the rural cemetery as places where the dead could be commemorated; their service would be remembered by the nation long after they were gone. The Mexican War was the first conflict wrapped up in these ideas and it made Americans deal with battlefield deaths far from home. In response, they wrapped the deaths of Mexican War soldiers in heroism and stylized last words and actions, bringing together a country-wide community to mourn. The perfect last moments of a hero's life exemplified resignation and acceptance mixed with Christian piety and faith, and these ideas carried over to the Civil War. Mark S. Schantz, Awaiting the Heavenly Country: The Civil War and America's Culture of Death (Ithaca: Cornell University Press, 2008), 2-4, 8-10, 13-15, 19, 26-30, 73, 82-87, 92, 119; Drew Gilpin Faust, This Republic of Suffering: Death and the American Civil War (New York: Alfred A. Knopf, 2008), xii-xiv; Lewis O. Saum, The Popular Mood, 83, 86-90; Lewis O. Saum, "Death in the Popular Mind of Pre-Civil War America," American Quarterly 26, no. 5 (December 1974): 479-481.
} 
"good death" had been separated from their religious roots and were part of respectable, middleclass behavior. ${ }^{43}$ Literary death narratives in the antebellum years spanned all genders, ages, and races, but continually highlighted acceptance, submission, and embracing death. Accepting death without question (including mass death and violent death) was part of accepting providence. By the time of the Civil War Americans were "so well armed with models of 'good deaths' that death itself was made to seem instructive, redemptive, and even glorious." ${ }^{44}$ A proper death was one that was witnessed, not only to provide comfort for the departing, but to provide inspiration to those witnessing a proper display of behavior. This meant that gathering family and friends around the deathbed was a key ingredient of dying; an unattended death was feared. Civil War soldiers heeded the instructive nature of the "good death." As Faust writes, "Death in war does

\footnotetext{
${ }^{43}$ The idea of the "good death" was central to Christian and American life, but it owed its roots back to the Ars Moriendi of fifteenth century Europe. During that period Europe was recovering from millions of deaths caused by the bubonic plague and warfare at the same time interior and exterior forces challenged ecclesiastical authority. Social rites and ceremonies preserve the values of a society; the Ars Moriendi emerged to uphold the Church's values in the midst of chaos. Two fifteenth century texts, the Tractatus, or Speculum, artis bene moreiendi and the Ars Moriendi were the beginning of the literary tradition of "dying well" (the Ars Moriendi was translated into English in a volume entitled the Crafte of Dying); this literary tradition developed into a social method of handling the death process. The Ars Moriendi explained the importance of learning the art of dying and alleviated the natural fear of death, outlined the temptations the dying person would face and the best ways to combat them, and directed bystanders how to help the dying man prepare himself. Included were interrogations to ask the dying person to establish their faith, prayers to be said by the dying person and prayers to be said over the person by those around them. In the whole process the dying person was expected to imitate Christ as much as possible, suffering their death "patiently, conforming and committing fully his will to God's will and to God's disposition alone ..." in order to attain the "good death." The tradition of the Ars Moriendi continued to be central in Europe through the next few centuries and preparation for death was a necessity of life as well as a part of religious consciousness. Both a "holy life and happy death" were upheld as the exemplary Christian way and family and friends gathered around the deathbed to witness the end of a life in the same way women gathered in a birthroom to witness the beginning of one. These witnesses watched the dying for signs of fortitude and grace and recorded words and silences to search for their significance. Quiet, calm deaths and confessions of faith were part of a "good death" and these deathbed scenes gave the survivors solace. A sudden death or death during sleep did not allow for such witnesses, but was interpreted by many as God taking the soul directly to its reward and did not necessarily signify a "bad death." Nancy Lee Beaty, The Craft of Dying: A Study in the Literary Tradition of the Ars Moriendi in England (New Haven: Yale University Press, 1970), 1-4, 7-8, 10-33, 38-45, 49; Frances M. M. Comper, ed., The Books of the Craft of Dying and Other Early English Tracts Concerning Death, Taken from Manuscripts and Printed in the British Museum and Bodleian Libraries, Now First Done into Modern Spelling and Edited by Frances M. M. Comper, with a Preface by the Rev. George Congreve, S. S. J. E. (New York: Longmans, Green, and Co., 1917), 6-7; Drew Gilpin Faust, This Republic of Suffering, 6; David Cressy, Birth, Marriage, and Death: Ritual, Religion, and the Life-Cycle in Tudor and Stuart England (New York: Oxford University Press, 1997), 389-392.

${ }^{44}$ Mark S. Schantz, Awaiting the Heavenly Country, 18.
} 
not simply happen; it requires action and agents. It must . . . be inflicted," which was the purpose of millions of soldiers during the war. "But," she continues, "death also usually required participation and response; it must be experienced and handled. It is work to die, to know how to approach and endure life's last moments." 45 Soldiers needed to be ready and willing to die and they turned to their culture to direct them as they faced death. ${ }^{46}$

The Civil War, however, shook the cultural foundations of "dying well." War presented a challenge not only in the unprecedented and unexpected number of casualties created by a largescale conflict with changing military weapons and transportation methods, but also in the violation of ideas about who should die and when, where, and how. Infant mortality and deaths of the elderly were expected and the ill and infirm knew the chances of their death; however, young and healthy men were taken in war, often instantly and without warning. Men were dying on the field of battle, far away from home and family, and often unattended, without the witnesses usually present in a "good death." Americans tried to construct "good deaths" in the difficult environment of war and maintain the values they held before the war to get them through what they were experiencing. Soldiers utilized the new technology of photography and carried pictures of loved ones with them on campaign; dead soldiers were sometimes found with these photos in their hands, surrogates for the family members who should have witnessed their last moments. ${ }^{47}$

However, the war created a situation where soldiers were dying far from their loved ones, and many died anonymous deaths far from home. As a result, soldiers, and their civilian families,

\footnotetext{
${ }^{45}$ Drew Gilpin Faust, This Republic of Suffering, xiv.

${ }^{46}$ Drew Gilpin Faust, This Republic of Suffering, 5-7; Mark S. Schantz, Awaiting the Heavenly Country, 36; Lewis O. Saum, The Popular Mood, 94-95.

${ }^{47}$ Drew Gilpin Faust, This Republic of Suffering, xii, 3-4, 11-12, 30-31. Amos Humiston of the $154^{\text {th }}$ New York is perhaps the most famous instance of a photograph found on the person of a dead soldier. After his death at Gettysburg on July 1, 1863, the ambrotype of three children found clutched in his hand eventually helped identify his remains and ensure a proper burial.
} 
developed a more detailed view of heaven as a place where families could reunite with one another. Nineteenth-century Americans constructed a vision of heaven that looked similar to their homes and believed that soldiers dying far away would "come home" and reunite with their families in the afterlife. ${ }^{48}$ Preparing for an April $2^{\text {nd }}$ assault on Petersburg in the last year of the war, a soldier of the $86^{\text {th }}$ New York wrote: "Jesus owns me, O, how sweet to feel that if we fall on the field of strife, we only fall to rise to higher and more perfect bliss than this world can give. My object is to live for heaven."49 A new, "modern" heaven was a perfected and more beautiful version of the life they knew, in which resurrected people would be reborn in perfected bodies, reunited with family and friends. The most important element of this vision was the fact that people would recognize each other when reunited in heaven; even though soldiers died away from home without their family, they would still see each other again after death. "May we meet again on earth," Captain Henry Kellogg wrote home, one of several times he mentioned heavenly reunion, "but above all may we meet in heaven our home never more to part." 50 The image of heavenly reunion was a comfort to both soldiers and families, and lessened the fear of death for those who had to face it daily. ${ }^{51}$

On May 19, 1863, Henry Kellogg wrote in his diary that "I suppose if we fight today my God must give me strength and success and prepare for death those who must die."52 The same day, comrades later remembered, Kellogg had a premonition of his own death for the following day, after which he wrote a letter to his wife, settled his affairs, and asked his friends to send his body home. On May $20^{\text {th }}$, before Vicksburg, the $33^{\text {rd }}$ Illinois was ordered to move positions

\footnotetext{
${ }^{48}$ Phillip Shaw Paludan, "Religion and the American Civil War," in Religion and the American Civil War, edited by Randall M. Miller, Harry S. Stout, and Charles Reagan Wilson (Oxford: Oxford University Press, 1998), 30-31.

${ }^{49}$ Steven E. Woodworth, While God is Marching On, 254.

${ }^{50}$ Michael R. Cunningham, "Follow me to victory or death," 7.

${ }^{51}$ Mark S. Schantz, Awaiting the Heavenly Country, 19, 30-31, 38, 40, 60-62, 67; Drew Gilpin Faust, This Republic of Suffering, 180.

${ }^{52}$ Michael R. Cunningham, "Follow me to victory or death," 35.
} 
through an area exposed to Confederate artillery fire and "[s]trange enough a rifle ball through the head took his [Kellogg's] life at the time he mentioned." ${ }^{53}$ Kellogg's first lieutenant, Edward J. Lewis, wrote a letter reporting the death to Kellogg's wife:

...your noble husband is no more, he died the death of a brave man on the $20^{\text {th }}$ while leading his company, sword in hand, in an important advance to a close position under the fire of the enemies' works. The fatal blow from a piece of shell in the head was at least merciful, in so far as that he died quietly and without suffering. His comrades were especially around him, but he never spoke after the shot. We have made every effort, by his special request before his fall, to send his body to you; but as no boats are allowed to assault the river at present, we have been compelled to postpone this purpose for the present. We design to fulfill it at the earliest providable time. ${ }^{54}$

Lewis' letter demonstrates how soldiers sought to transition ideas of the good death into a war where men died far from home. Lewis failed only to provide commentary on Kellogg's moral and religious character in following the model of "good death" narratives. He provided Mrs. Kellogg with details of the mortal injury, assured her that her husband was surrounded by comrades at the time, and reported on final words and actions (in this case, none). Lewis also framed Kellogg as dying a brave death and gave his death consequence and meaning by telling her that it occurred during an important advance. By framing the deaths in these letters within the familiar terms of the "good death,"-giving details to make family members "witnesses" to the event, reporting last words and actions, and speaking of good morals or religious valuessoldiers tried to make families back home feel connected to the last moments of their loved ones' lives, but also tried to understand the death for themselves. ${ }^{55}$

\footnotetext{
${ }^{53}$ Isaac H. Elliott, General, History of the Thirty-Third Regiment Illinois Veteran Volunteer Infantry in the Civil War, 22 ${ }^{\text {nd }}$ August, 1861, to $7^{\text {th }}$ December, 1865 By General Isaac H. Elliott with Company and Personal Sketches by Other Comrades, Also Complete Historical Rosters compiled by Virgil G. Way (Gibson City, IL: Published by the Regimental Association, 1902), 16, 195.

${ }^{54}$ Michael R. Cunningham, "Follow me to victory or death," 1 (first page of letters section).

${ }^{55}$ Drew Gilpin Faust, This Republic of Suffering, 14-19.
} 
Unfortunately for Kellogg's wife, his body remained buried at Milliken's Bend because the location of the grave was lost. ${ }^{56}$ The very real possibility of an anonymous burial in a location far from home reaffirmed the newly emerging ideas of heaven. A similar letter written by Corporal Frederick Pettit's captain after he was killed by a sharpshooter in the trenches at Petersburg, began as the Kellogg letter did, with "your noble son is no more." Following the idea of the "good death" narrative, Captain Critchlow detailed the circumstances of Pettit's death, then assured the family that "he died as he lived, a devoted and exemplary Christian and I trust and believe your loss is his eternal gain." ${ }^{\circ 7}$ Critchlow demonstrates the combination of familiar “good death" ideas taken from soldiers' civilian lives and the evolution of faith to include the idea of heavenly reward and reunion. By placing trust in a higher power, soldiers used religion to support themselves mentally and emotionally during the Civil War. This faith in God took the possibility of death and gave it meaning by placing it within a larger plan in which men had no control. More importantly, the hope for salvation and reunion in heaven was particularly important for men dying far from home, away from loved ones and an assured "good death." Civil War soldiers molded cultural norms of death and faith to meet their wartimes needs, ultimately changing society's views on heaven as a welcoming place of reunion where families could be reunited once more.

Religion proved a strong coping mechanism for many Civil War soldiers, however other cultural concepts of masculinity and courage also helped men handle their wartime experiences. ${ }^{58}$ After the Battle of the Wilderness in May 1864, in which his regiment had lost

\footnotetext{
${ }^{56}$ Isaac H. Elliott, General, History of the Thirty-Third Regiment Illinois, 16.

57 William Gilfillan Gavin, Infantryman Pettit, 166.

${ }^{58}$ Gerald Linderman argues that the set of values soldiers brought into the military centered on courage and, its opposite, the fear of cowardice. Wartime evidence suggests that courage was not necessarily in the center of the Civil War soldier's mindset, as Linderman claims. Linderman's reliance on post-war memoirs may explain his argument; courage may have factored more prominently in reminiscences far after the death and destruction had
} 
eighty men killed and 254 wounded over two days, Wilbur Fisk of the $2^{\text {nd }}$ Vermont wrote, "I am sure that if I had acted just as I felt I should have gone in the opposite direction . . . but I wouldn't act the coward."59 Those who did "act the coward" were labeled skulkers and faced shame and derision from fellow comrades and in some cases faced formal punishment that could severely damage one's reputation. "The others shame those few so much," reported a New Hampshire man, "that they must of necessity come up to scratch or be in disgrace." ${ }^{60}$ Not only were men in danger of censure in the army, but reports of cowardice swiftly made it home in letters and newspaper reports; in order to keep his own good name and that of his family, a soldier had to avoid the label of coward. In some cases, men went so far as to go into battle even though they were wounded or ill, and men in behind-the-lines positions pulled strings to be placed in combat. A lieutenant colonel who broke down in June 1864 returned to his regiment after only a week in the hospital because "those who keep up are full of ugly feelings toward those who fall [behind], intimating in every way possible that it is cowardice that is the cause."61 By returning to the regiment and facing the same dangers as his men, he could avoid those charges. Courage as an ideal certainly inspired some men to face the test of battle, but more often it was the fear of shame resulting from a charge of cowardice that kept men in line. ${ }^{62}$

Soldiers strove to prove their courage through actions in which they betrayed no sense of fear in combat, in camp, and in the hospital. "Every man marched up to the breastworks as cool and determined as if they were made of steel" wrote an infantryman in 1863, describing a proper

settled. See Gerald F. Linderman, Embattled Courage: The Experience of Combat in the American Civil War (New York: The Free Press, 1987).

59 James M. McPherson, For Cause and Comrades, 82.

${ }^{60}$ James M. McPherson, For Cause and Comrades, 78.

${ }^{61}$ James M. McPherson, For Cause and Comrades, 82.

62 James M. McPherson, For Cause and Comrades, 5, 37, 77-82; Gerald F. Linderman, Embattled Courage, 56-57; Lesley J. Gordon, "'I Never Was a Coward': Questions of Bravery in a Civil War Regiment," in More Than a Contest Between Armies: Essays on the Civil War Era, edited by James Marten and A. Kristen Foster (Kent, OH: The Kent State University Press, 2008), 145-146. 
battlefield display. ${ }^{63}$ Resisting reactions of fear could truly be a struggle for some soldiers facing battle. Artilleryman William Christie admitted to his father that, even though he had stood firm on the field of battle before, an engagement before Vicksburg in late May 1863 made him feel so nervous he wanted to run away. Despite being "desperately afraid" he remained in his post, thinking about his duty and trusting in God, but, he told his father, "could you have seen my inner self, you would have seen a very strange trial of strength." ${ }^{\prime 64}$ These actions proved one's manhood and masculinity — Christie said that his actions in the very battle in which he had his inner struggle of courage encouraged comrades to consider him "good coin anywhere"-or jeopardized one's reputation if they failed the test. ${ }^{65}$

The dual ideas of courage and cowardice certainly assisted men in multiple ways during their military service. It helped maintain good discipline on the battlefield and steeled men against reacting to the sights of death and destruction all around them. William Phillips admitted that he did not like battle, but he went in when ordered because his "stock in the trade was about an ounce of courage and the balance in pride and honor. With that, I manage to put on a bold face. ${ }^{" 66}$ Courage also ensured success, for they believed that the brave would live and the cowardly would die, and if the brave did die then they died well. In defeat, soldiers could still cheer their performance if they had fought to the best of their abilities ${ }^{67}$ After Wilbur Fisk declared that he would not "act the coward" at the Wilderness despite his fear, he wrote that, "I clenched my musket and pushed ahead determined to die if I must, in my place and like a man." ${ }^{68}$ Notions of courage and bravery were interwoven with ideas of manhood and

\footnotetext{
${ }^{63}$ Delavan Bates to father, November 8, 1863. SoldierStudies.org, accessed December 1, 2011.

${ }^{64}$ William G. Christie to father, May 31, 1863. SoldierStudies.org, accessed November 29, 2011.

${ }^{65}$ Gerald F. Linderman, Embattled Courage, 20-23, 27.

${ }^{66}$ William Beynon Phillips to Annie, July 4, 1864. SoldierStudies.org, accessed November 11, 2011.

${ }^{67}$ Gerald F. Linderman, Embattled Courage, 2, 43-45, 61-65.

${ }^{68}$ James M. McPherson, For Cause and Comrades, 82.
} 
masculinity; a soldier who did his duty and fought well was a man, a coward was not. "I do most earnestly hope that I may be enabled to meet my duties like a man when the breath of battles blows around me," wrote a corporal in the $64^{\text {th }}$ Ohio, "I do hope I may be brave and true for of all names most terrible and to be dreaded is coward." ${ }^{69}$ Civil War soldiers were afraid of battle, and as they passed their first tests of fire they began to admit it more openly. "The man who does not dread to die or to be mutilated is a lunatic," wrote veteran John W. De Forest after the war. But, despite this fear soldiers still went forward because they were more afraid of cowardice than of death. Being brave and avoiding the shame of cowardice were the same as meeting the “duties" of manhood. War was a prime opportunity to prove one's manhood by showing proper displays of behavior, but the Civil War was a time "when the motto, 'Death, or an honorable life,' [tried] more sharply the manhood of him who adopts it" than previously. ${ }^{70}$ The environment of war made fulfilling these duties more difficult, but soldiers looked to prove themselves within their personal definitions of manhood.

For soldiers in their late-teens and early-twenties, the Civil War was literally their “coming of age." While ideology played some part in a soldier's decision to fight, it was also a test of their own masculinity and worth. To face death and either survive or fail was the ultimate trial of manhood. ${ }^{71}$ Leaving home for war, many for the first time, these men explored new found freedom while trying to uphold expectations of masculinity, a boundary which itself was shifting. Americans in the middle of the nineteenth century experienced a shift in the definition of masculinity. There was no single conception of manhood going into the war years and men

\footnotetext{
${ }^{69}$ James M. McPherson, For Cause and Comrades, 82.

70 James Kendall Hosmer, Diary Entry for March 13, 1863, In The Color-Guard: Being a Corporal's Notes of Military Service in the Nineteenth Army Corps (Boston: Walker Wise and Co., 1864), 83. American Civil War: Letters and Diaries, accessed December 1, 2011, (Hosmer:D1425-8).

${ }^{71}$ Stephen William Berry, All That Makes a Man: Love and Ambition in the Civil War South (Oxford: Oxford University Press, 2003), 9-10.
} 
practiced their masculinity in a variety of ways, including boxing, melodrama and minstrelsy, self-restraint and discipline, membership in organizations or men's clubs, dueling, expressions of fraternal love (primarily within abolitionism), competition, and politics. ${ }^{72}$ Some of these men held themselves to standards of gentility: self-control, self-improvement, cleanliness, and etiquette. These men resisted yielding to the temptations of camp. Byron B. Wilson wrote, "I am just the same here as at home. I know one need not lose his manhood in becoming a soldier."73 Other soldiers ascribed to camaraderie defined by noise, unruly behavior, and physical prowess. Neither the military nor all men fully supported either idea of "proper" behavior. Army regulations supported the moral conduct exhibited by the "gentlemen," but there was no set definition of these behaviors. On the other hand, the rowdy behavior of the "roughs" offended standards of army discipline, but violence was sometimes acceptable in matters of honor. Marylander John Rastall had to arrest five men who had forcefully cornered one of their lieutenants in a bar, but his solution to the situation was to call in his men and start a street fight. Called to confront "unhonorable" behavior, Rastall used similar behavior as his solution, illustrating how murky the lines of honor and manhood were. ${ }^{74}$ Both concepts were accepted, denied, and adapted by the army and its soldiers, and the men took elements of both to define their personal masculinity.

\footnotetext{
${ }^{72}$ Amy Greenberg argues there were two main types of masculinity during this period: "restrained manhood" and "martial manhood." Restrained manhood put priority in family, faith, and business success, believed in domesticity as the moral center of the world, and refrained from blood sports and excessive drinking. This manhood was derived from being morally upright, reliable, and brave. Martial manhood, on the other hand, rejected these moral standards and believed their masculinity was defined by strength, aggressiveness, and violence. See Amy S. Greenberg, Manifest Manhood and the Antebellum American Empire (New York: Cambridge University Press, 2005). Lorien Foote argues that artificial categories should not be created to fit men into and that each man's individual values shaped his definition of masculinity. Her work practically mirrors Greenberg's argument, however, as she divides Union soldiers into the categories of "gentleman" and "rough." See Lorien Foote, The Gentlemen and the Roughs: Manhood, Honor and Violence in the Union Army (New York: New York University Press, 2010). See also: Reid Mitchell, The Vacant Chair, 5-7.

${ }^{73}$ Byron B. Wilson, "Letter XXXVI," Soldiers' Letters, from Camp, Battle-field and Prison (New York: Bunce \& Huntington, 1865), 99. American Civil War Letters and Diaries, accessed December 1, 2011, (Wilson:L1441-33).

${ }^{74}$ John E. Rastall to parents, May 20, 1864. SoldierStudies.org, accessed December 1, 2011.
} 
With the shifting definitions of manhood in the nineteenth century, the most important thing was that others recognized and respected a man's conception of masculinity, their reputation for masculine self-restraint or aggression, particularly the men in his company and regiment whom he interacted with closely. Only then could a man feel that he had proven himself. ${ }^{75}$ Courage, honor, and manhood were closely entwined for soldiers ascribing to both sides of the masculinity spectrum, and the loss of courage or fighting spirit was equated with the loss of manhood. "Courage was intimately connected with honor...and with self-control...," writes Lorien Foote, "Obviously a man overcome by his fear had lost control of his emotions and was... 'unmanned." "76 Important in this definition of manhood or being "unmanned" was the recognition of masculinity, courage, and honor by comrades and officers. Cowardice or the loss of standing with one's comrades could equate to a "burial of manhood and self-respect" and permanently damage a soldier's reputation. ${ }^{77}$

Deeply imbedded in the language of courage and cowardice was a soldier's connection to their families and comrades. "You ask me if the thought of death does not alarm me. I will say I do not wish to die," admitted a New York soldier to his sister in 1864. "I myself am as big a coward as eny could be," he continued, "but give me the ball [bullet] before the coward when all my friends and companions are going forward." 78 On the one hand, a man's decision to become a soldier meant they accepted their responsibility to defend home and country and fight for one's immediate family, extended national family, ancestors, and future generations. ${ }^{79}$ Duty to country certainly spurred some men to keep up the fight. "You spoke of my keeping up good courage,"

\footnotetext{
${ }^{75}$ Lorien Foote, The Gentlemen and the Roughs, 4, 19-28, 51, 55, 57, 67, 77, 89.

${ }^{76}$ Lorien Foote, The Gentlemen and the Roughs, 57.

${ }^{77}$ Gerald F. Linderman, Embattled Courage, 57.

${ }^{78}$ James M. McPherson, For Cause and Comrades, 87.

${ }^{79}$ Reid Mitchell, The Vacant Chair, 11-15.
} 
one soldier wrote, “in this when our country's and liberty is at stake, if we did not keep up good cheer I would not answer for the safety of our cause. ${ }^{~}{ }^{80}$ Charles Lynch would have agreed when he wrote in June 1864, "[we] keep up courage very well as we endure these hardships, all for our country." ${ }^{\prime 11}$ On the other hand, the decision to fight was also very personal and soldiers found themselves fighting for their family and the comrades around them.

Family and familiar cultural norms were crucial coping tools for Union soldiers, but home was also very far away. The family was the prime social organization that defined expectations of manhood, and thus it became a commonly used metaphor, as well as a framework for structuring wartime relationships. Soldiers built new families among officers and comrades to provide needed support systems within the army. Men described Abraham Lincoln, and more specifically their officers, as father figures who took care of them and were to be obeyed. In many cases, company officers were usually older men of the regiment's community who were in a "father-like" position before the war and had promised parents they would look after the "boys." Officers needed to show bravery, but more importantly they needed to look out for their men. Speaking of General Mott, Matthew Austin of the $5^{\text {th }}$ New Jersey wrote that Mott had "won the esteem of all who came in contact with him." The General had proven himself a brave man, Austin continued, but he was "brave, without being rash—knowing how to save his men from unnecessary danger or death - which required a cool head to judge of in the time of battle." 82 Officers who commanded only for their own advancement, or to "retrieve lost 'reputation"” received little respect from the men they led. In addition, officers who did not lead by example, or worse showed cowardice, were reviled and those who enjoyed more comfort than

\footnotetext{
${ }^{80}$ Justus G. Matteson to Mary, December 3, 1863. SoldierStudies.org, accessed November 11, 2011.

${ }^{81}$ Charles H. Lynch, diary entry for June 22, 1864. SoldierStudies.org, accessed November 11, 2011.

${ }^{82}$ Matthew S. Austin to father, September 23, 1862. SoldierStudies.org, accessed December 1, 2011.
} 
their men were cast in a bad light. Enlisted men expected their officers to show the right balance of masculine bravery and feminine care. Beloved officers who commanded the respect of their troops on and off the field were often those who visited the sick and wounded in the hospital, made sure their men had the supplies and care they needed, and assisted with financial troubles. Officers understood their position and the power structure of the camp; the colonel of the $54^{\text {th }}$ Ohio commented that men in his position were "compelled to be a father to a large family who call on him for every thing. ${ }^{" 83}$ More noted were the officers who shared the burden of the march, walking with the men or allowing soldiers to ride their horse for periods of time, and who lived in the same conditions as the rest of the regiment; this garnered them respect from their troops that at times bordered on devotion. As the father of a military family, officers were expected to treat their soldiers with equality while maintaining their position of command and respect. ${ }^{84}$

If the officers were the patriarchs of the military family, a soldier's close companions and messmates were part of a brotherhood. Pride and honor in groups such as regiment, state, and nation were certainly motivators for soldiers, but the "primary" association fell with the small group men associated with in daily life. Soldiers created fictive families among their fellow enlisted men while they were away from their real family back home. This "band of brothers" was bonded through mutual dependence. "You would not believe that men could be so attached to each other," said a member of the $1^{\text {st }}$ Ohio Heavy Artillery, but "we are all like brothers." $" 85$ Not only did they support each other by sharing tents and company and cooking rations together, these men could also understand what each other felt because they were experiencing the same

\footnotetext{
${ }^{83}$ James M. McPherson, For Cause and Comrades, 54.

${ }^{84}$ James M. McPherson, For Cause and Comrades, 53-60; Reid Mitchell, The Vacant Chair, 115-119, 127-132.

${ }^{85}$ James M. McPherson, For Cause and Comrades, 86.
} 
thing. The same trauma that could cause emotional or psychological damage also strengthened a soldier's connection to his unit because they were all facing the same stress. ${ }^{86}$

The tight bonds of camaraderie built through marching, fighting, and camp life were a major factor in keeping men in the ranks. If one man shirked his duty or showed cowardice it might endanger the survival of the entire group; peer pressure among these small messes to avoid cowardice was heavy. After Ed Ford, "considered one of the brave and reliable men of the Co.," ran during a battle in 1861 it mortified his comrades. Ford's actions caused the dissolution of his mess and alienated his comrades. Captain Francis Adams Donaldson wrote that "Ford rapidly lost cast and there after was of no account except to be company clerk for Captain Mallery." 87 Donaldson allowed Ford to still tent with him, but he was now a non-combatant. ${ }^{88}$ The loss of self-respect and camaraderie caused by being ostracized from one's primary association group was incentive for soldiers to fight. The strong bonds of comradeship not only supported soldiers physically and emotionally in camp, they also provided incentive and reinforcement on the field of battle. ${ }^{89}$ S. L. A. Marshall argued that human contact was the most important element to a soldier's courage on the battlefield, saying "I hold it to be one of the simplest truths of war that the thing which enables an infantry soldier to keep going with his weapons is the near presence

\footnotetext{
${ }^{86}$ Gerald F. Linderman, Embattled Courage, 234-236; Earl J. Hess, The Union Soldier in Battle, 111-122; James M. McPherson, For Cause and Comrades, 82-83, 85-87; Craig J. Bryan, et al, "Combat Experience and the Acquired Capability for Suicide," Journal of Clinical Psychology 66, no. 10 (2010): 1046-1047; Mark H. Dunkelman, Brothers One and All: Esprit de Corps in a Civil War Regiment (Baton Rouge: Louisiana State University Press, 2004), 5-6, 10; Richard Holmes, Acts of War, 292-300.

${ }^{87} \mathrm{~J}$. Gregory Acken, Inside the Army of the Potomac: The Civil War Experience of Captain Francis Adams Donaldson (Mechanicsburg, PA: Stackpole Books, 1998), 24-25.

${ }^{88}$ Ibid.

${ }^{89}$ Gerald F. Linderman, Embattled Courage, 234-236; Earl J. Hess, The Union Soldier in Battle, 111-122; James M. McPherson, For Cause and Comrades, 82-83, 85-87; Craig J. Bryan, et al, "Combat Experience," 1046-1047; Mark H. Dunkelman, Brothers One and All, 5-6, 10; Richard Holmes, Acts of War, 292-300.
} 
or the presumed presence of a comrade." 90 Standing side-by-side with their military family gave many men the strength to move forward on the battlefield.

This "primary group" was crucial to the soldier's ability to cope with their wartime experiences. In their quantitative study of Civil War soldiers, Dora Costa and Matthew Kahn argue that small group loyalty was more than twice as important as ideology and six times as important as leadership for keeping men in the ranks. ${ }^{91}$ These men provided the immediate support network for soldiers, mentally and physically. Not only were these men instrumental in providing the "self-care" described by Kathryn Meier — caring for each other when ill, cooking rations together, and foraging for needed supplies - they also provided the psychological support needed to survive the war. This comradery provided needed incentive on the battlefield, as fighting in line with friends gave men courage, but this support extended past the battlefield. A soldier's "mess" was the first to discuss battlefield experiences, religion, and support each other in moments of weakness. These close comrades would share letters and packages from family with comrades that received none and would help keep each other connected to home. In the case of illness, injury, or death a soldier's close friends would ensure care (to their ability), burial, or communication with loved ones at home. In the cases of mental breakdown or insanity, it was often the soldier's close circle that provided immediate support, sometimes for an extended period of time, before the soldier received official care. Testimonies of soldiers who watched over insane comrades, soothed friends from nightmares, aided men suffering from heatstroke, all attest to the soldiers themselves being the front-line of coping and ensuring mental survival of the war.

\footnotetext{
${ }^{90}$ S. L. A. Marshall, Men Against Fire: The Problem of Battle Command in Future War (New York: The Infantry Journal and William Morrow \& Company, 1947), 42.

${ }^{91}$ Dora L. Costa and Matthew E. Kahn, Heroes \& Cowards: The Social Face of War (Princeton: Princeton University Press, 2008), 118.
} 
Concrete connections were sustained with family and friends back home and built between comrades sharing the hardships of war. If, for some reason, a soldier experienced difficulty or a weakening in the familial bonds, they could look to the men around them for support, and if the brotherhood of arms failed a soldier looked back to family. For example, after catastrophic losses at Gettysburg William Charles wrote to his wife, "Since that Battle I have felt very lonesome \& if it was not for you \& those two little ones I would rather die than not you see all the Welsh boys are gone every one of them and I am left alone." 92 Charles' bonds with his military family had weakened, but he still had his wife and children. Maintaining connections to one's civilian life were also sustained in more abstract forms; maintaining religious beliefs and relying on familiar social norms provided more subtle reminders of a larger community in which the soldier lived. The Union army was primarily one of volunteers who wanted to distinguish themselves from the professional soldier. By continually reasserting their position as civilians before soldiers, Union men reaffirmed their connections to their home society. Feeling close connections to individual family members, friends, and comrades, as well as broad connections to a wider society and military organization meant that soldiers had many places to turn for support.

Beyond cultural tools that soldiers used to cope, they also concerned themselves with keeping busy to avoid homesickness and depression. James Criswell of the $126^{\text {th }}$ Ohio wrote to his wife, Lizzie, in 1862, that he worried that he would become tired and bored once the poor winter weather set in, but that he was trying to keep his spirits up. "[I]t is the worst thing that can happen to a soldier, to get homesick," Criswell wrote, "for they are no company to the rest of

\footnotetext{
${ }^{92}$ Mark H. Dunkelman, Brothers One and All, 95.
} 
them, they can't eat, and if it lasts long, disease of some kind is the consequence." 93 Thus, "they must keep up their spirits or else they are of no account." ${ }^{\text {94 }}$ Soldiers used other amusements to keep themselves busy and keep their spirits up. Besides drill, soldiers would pursue sports and other physical activities during the warmer months. Jokes and pranks were common, especially in camp and sometimes to a dangerous level. Soldiers would also handcraft small items, particularly whittled pieces of wood. Other amusements included music, debates, plays, cards, worship or prayer, and reading. ${ }^{95}$ Opposite the more wholesome amusements in camp were the many perceived vices available to soldiers. Families warned their men to avoid amusements such as drinking, gambling, and profanity, but many men partook of these while in the army. ${ }^{96}$ These amusements available to soldiers in camp have been previously analyzed as part of a soldier's daily life and culture, as ways to relieve the boredom of camp. However, these amusements also served as coping techniques, maintaining connections to their civilian identity, relieving the stress and tension of soldiering, and keeping morale up to ensure the soldier's mental wellbeing. The official definition of "nostalgia" recognized homesickness and boredom as factors increasing the likeliness a soldier would suffer the ailment, and recommended that officers keep their men occupied in camp with various activities meant to improve their soldiering, enhance the camp, and overall keep the men mentally and physically occupied. ${ }^{97}$ By keeping themselves

\footnotetext{
${ }^{93}$ James Criswell $\left(126^{\text {th }} \mathrm{OH}\right)$ to Lizze, Camp McCook, Cumberland, MD, December 6, 1862. Fredericksburg \& Spotsylvania NMP Collections, Ohio Manuscripts, Volume 259.

94 Ibid.

${ }^{95}$ James I. Robertson, Jr., Soldiers Blue and Gray, 82-93; Michael Barton and Larry M. Logue, ed., The Civil War Soldier: A Historical Reader (New York: New York University Press, 2002), 102-103; See also, Bell I. Wiley, The Common Soldier of the Civil War (New York: Charles Scribner's Sons, 1975) and Bell I. Wiley, The Life of Billy Yank: The Common Soldier of the Union (The Bobbs-Merrill Company, Inc., 1951, 1952).

${ }^{96}$ James I. Robertson, Jr., Soldiers Blue and Gray, 81, 93-101.

${ }^{97}$ The Medical and Surgical History of the Civil War, Volume VI [Formerly entitled The Medical and Surgical History of the War of the Rebellion] (Wilmington, NC: Broadfoot Publishing Company, 1991), 884-886.
} 
occupied, soldiers could engage in activities that took the edge off their experiences and kept their mind off the dangers ahead.

Despite efforts by the temperance movement to curb drinking in the armies, soldiers used alcohol in a variety of ways to manage their wartime experiences. Officers were allowed to drink freely while private soldiers were technically not supposed to, although most did have access to alcohol despite official regulations, and most working-class men did not follow the sobriety demanded of white, middle-class reformers. Soldiers used drinking to make camp more like home, particularly during holidays, and fight the boredom of camp life. For soldiers accustomed to the presence of alcohol in everyday life or special festivities, the absence of drink could make the separation from their civilian world keener. Men also used drinking to fight homesickness and nostalgia, and forget the imminence of death and destruction during a campaign. Alcohol could take a soldier's mind off thoughts of home and take the edge off of the anxiety before battle. $^{98}$

Despite official restrictions on drinking among private soldiers, officers and soldiers alike used alcohol for practical uses in the army in addition to those meant to relieve the boredom or stress of soldiering. Alcohol rations were provided to soldiers who were performing a particularly extreme duty—long marches, battle, burial duty, or constructing earthworks—or were performing duty in poor weather conditions. These rations were at the discretion of the commanding officers, so there was little consistency in implementing the army's official alcohol policy. The army also regularly used alcohol for medicinal purposes, for the prevention and treatment of illness and to stimulate the wounded and promote healing. Because of the transition in medicine occurring at the time of the Civil War, there was still a reliance on traditional

\footnotetext{
${ }^{98}$ Megan Leigh Bever, "War is a Terrible Enemy to Temperance: Drinking, Self-Control, and the Meaning of Loyalty in the Civil War," (Ph.D. Dissertation, The University of Alabama, 2014), 1-5, 14-22, 23-26.
} 
remedies, many of which used alcohol. Doctors focused on the "stimulating" effects of alcohol, judging the numbing or intoxicating effects as just side effects, and believed that alcohol increased the "vital activity" of the body to treat disease and heal wounds. The Union army particularly used alcohol against Malaria and a mixture of whiskey and quinine was often rationed out to troops if there was a lot of disease in camp to prevent further illness and treat those already ill. For the wounded, doctors believed that doses of wine and brandy could help with blood loss, stimulate healing after surgery, and mitigate shock by "restoring nervous energy" in patients. ${ }^{99}$

Alcohol supplies predominantly went to hospitals and to commanding officers for distribution as rations, but these supplies often ran low. In those cases, officers would seek to procure alcohol for their men through private channels and soldiers would ask family members to send them the needed supplies. Even more than military officials and physicians, soldiers relied on traditional methods - many of which tie into the idea of "self-care" — to fight illness and remain healthy. As Meier argues in Nature's Civil War, soldiers equated the environment with their own health and they used alcohol as one way to fight the disease and exhaustion that would make them sick. Soldiers kept private stores of liquor to treat themselves or their comrades when they fell ill or were wounded in battle. Many men carried alcohol into battle because they believed it would help the wounded and revive men who became faint. ${ }^{100}$ Whether for medicinal purposes or to ease the stress of camp life and soldiering, men used alcohol in various ways to cope with their wartime experiences.

\footnotetext{
${ }^{99}$ Megan Leigh Bever, "War is a Terrible Enemy to Temperance," 110-112, 182-190; R. Gregory Lande, Madness, Malingering, and Malfeasance: The Transformation of Psychiatry and the Law in the Civil War Era (Washington, D.C.: Brassey's Inc., 2003), 81-113.

${ }^{100}$ Megan Leigh Bever, "War is a Terrible Enemy to Temperance," 192, 208-213.
} 
Soldiers used the coping mechanisms analyzed above to handle the overall experiences of soldiering and combat, but battle presented one specific challenge to soldiers - killing another human being — where civilian society provided no foundation for coping. Dave Grossman explains that "[1]ooking another human being in the eye, making an independent decision to kill him, and watching as he dies due to your action combine to form one of the most basic, important, primal, and potentially traumatic occurrences of war." ${ }^{101}$ For soldiers, killing others went against societal expectations and religious beliefs, and Civil War soldiers had to make decisions on the battlefield that could mean life or death for themselves, their comrades, and their enemies. A soldier is trapped between the guilt of killing and its necessity on the battlefield to preserve their own life, protect their comrades, and further their cause. Not killing the enemy on the battlefield could endanger the lives of comrades and ruin a soldier's reputation, so soldiers had to face the burden of killing. As Drew Faust argues, Civil War soldiers participated in a war where volunteer soldiers with little training had to made independent decisions whether to fire their weapons and kill, sometimes in close situations where they could see the men they were killing. ${ }^{102}$ In addition, close combat lessened the possibility of denying both of these things and was usually more traumatic to soldiers because they could personally see the soldiers they killed, even if fighting to preserve their own lives. ${ }^{103}$ Soldiers could turn to common cultural normssuch as religion, ideas of the "good death" and heaven, masculinity, and courage - as well as support from family to cope with the fear of dying. Killing, however, was unsupported in civilian life and there was nothing in their civilian culture to support killing another human, except that it

\footnotetext{
${ }^{101}$ Dave Grossman, Lt. Col., On Killing, 31.

102 Dave Grossman, Lt. Col., On Killing, 86-92, 97-137; Drew Gilpin Faust, This Republic of Suffering, 33-56.

${ }^{103}$ Dave Grossman, Lt. Col., On Killing, 86-92, 97-137.
} 
was a military necessity in wartime for men to die. With most cultural support focusing on the process of dying, soldiers had to develop ways to deal with killing on the battlefield.

Soldiers often try to create emotional distance between themselves and their enemy in an attempt to dehumanize the soldiers they were required to kill and deny personal responsibility in another human's death. This coping tactic can be seen in wider military history through cultural distance — emphasizing racial and ethnic differences to make the enemy seen inferior-, moral distance-legitimizing one's own cause as "holy" or "moral" while delegitimizing the enemy's cause, or seeking revenge for a previous transgression of the enemy- and social distancehighlighting class differences, particularly in seeing lower class soldiers as less than human. Distance can also be created physically; using technology—for example, cannon, bombs, or torpedoes - to kill from a distance allows the soldier to view the enemy as inhuman targets. ${ }^{104}$

In the Civil War, the stereotypical images of "Yankee" and "Rebel" fulfill this need to create distance between soldiers and their enemies. Because combatants were all Americans and had similar ethnic and historical backgrounds - the idea of a "brother's war"-, creating this distance could be difficult. Both sides, however, constructed an image of the other that defined the enemy as "evil" and themselves as fighting a "just cause." The South pictured northerners in the context of industrialized society: grasping, greedy, concerned only with money, and capable of only mechanized tasks. They believed northerners were corrupt and cruel, and coming to subjugate the South. Northerners, expecting the cavalier Southerner portrayed in literature and propaganda, came to define Southerners instead as unintelligent and lacking initiative. Both stereotypes were inaccurate, however they reflected the cultural concerns and differences of North and South, and were used to paint the enemy as different and evil. Creating an image of

${ }^{104}$ Dave Grossman, Lt. Col., On Killing, 156-170. 
the enemy that not only dehumanizes them, but also paints them as evil, is crucial to making men fight; when soldiers identify with their opponents it makes it harder to fight and kill in battle. ${ }^{105}$

To cope with the necessity of killing on the battlefield, soldiers tried to make those deaths as impersonal as possible to avoid individual responsibility for taking another life. In an 1861 letter William P. Lyon wrote about an engagement near Frederickstown: "You ask me how I felt when going into battle. It is hard to analyze my feelings, I did not forget the danger to myself, but I was cool and self-possessed...The roar of the artillery, the rattling of musketry, and the sight of the wounded and dead men was very solemn. It was necessary, however, and I take my full share of responsibility; although, of course, none fell by my hand."106 Similarly, Thomas J. Bartholomew wrote near Corinth on May 25, 1862 that during an exchange of artillery fire across the breastworks, "it is said we killed some of the rascals but of this I know nothing certain." ${ }^{107}$ Soldiers tried to deny individual responsibility and create distance between themselves and enemy deaths to cope with their actions during battle. George A. Hitchcock of the $21^{\text {st }}$ Massachusetts wrote after fighting at Antietam about seeing friends and neighbors falling dead in battle, but not being able to react. He wrote, "My only duty was to take sure aim into the rebel ranks and forget the carnage..." ${ }^{108}$ While he is reflecting on his focus in battle on duty and the inability to react to the death of his friends, this passage uses language that supports creating distance. He says he takes aim into the ranks, which distances himself from targeting a certain enemy soldier and from taking responsibility for enemy deaths. In addition, by using the term "rebel" he is using language that hides the humanity of his targets. Both sides used the language

\footnotetext{
${ }^{105}$ Richard Holmes, Acts of War, 360-393; Randall C. Jimerson, The Private Civil War: Popular Thought During the Sectional Conflict (Baton Rouge: Louisiana State University Press, 1988), 125-179; Jason Phillips, “A Brother's War? Exploring Confederate Perceptions of the Enemy," in The View from the Ground: Experiences of Civil War Soldiers, edited by Aaron Sheehan-Dean, 67-90 (Lexington, KY: The University Press of Kentucky, 2007), 69-70. ${ }^{106}$ William P. Lyon letter, October 25, 1861. SoldierStudies.org, accessed June 18, 2012.

107 Thomas J. Bartholomew letter to "Bro William", May 25, 1862. SoldierStudies.org, accessed June $19,2012$.

${ }^{108}$ Ronald Watson, ed. From Ashby to Andersonville, 21-22.
} 
of "Rebs" and "Yanks" to create distance between two combatants that were in reality very similar.

Another way soldiers coped with the necessity of killing in battle and tried to distance themselves from it was falling back on the routines of training. As examined in chapter one, loading and firing were a routine action that soldiers focused on in the heat of battle, but it also helped dehumanize the enemy. Ideally, new Civil War soldiers would train for several hours a day to instill discipline and prepare for combat. However, training for the Union army was not uniform and many soldiers received poor training for several reasons. In some cases, regiments were called up quickly to the field with little time for extensive drill past learning how to load and fire their weapons and march together. In addition, in many volunteer regiments the officers had no military experience, having been elected by the men of their community and regiment, and they struggled to learn enough military drill and tactics to teach their men. In many cases, officers had to stay one step ahead of their soldiers and learned by experience as well as reading tactical manuals. A problem in relying on volunteer regiments formed within the same community was that soldiers were less willing to submit to the strict drill and discipline of the army, preferring to maintain their civilian independence and continuing to see their officers as neighbors. ${ }^{109}$ The core of Civil War drill was how to load and fire their weapon and it was this reason that soldiers could automatically fall back on that mechanic during battle above other military tactics.

An additional way to analyze how Civil War soldiers tried to distance themselves from killing the enemy through focusing on the wider action and making these deaths impersonal is how they reacted to sharpshooters or soldiers who targeted a single enemy soldier outside battle.

\footnotetext{
${ }^{109}$ Joseph Allan Frank and George A. Reaves, "Seeing the Elephant": Raw Recruits at the Battle of Shiloh (Urbana, IL: University of Illinois Press, 1989), 26-30, 48-54; James I. Robertson, Jr., Soldiers Blue and Gray, 122-128.
} 
Sharpshooters, and other soldiers, gained the intense hatred of most soldiers when they targeted one particular victim, usually at a time where that person was not a direct threat to the killer. William Fisk looked askance at the actions of a comrade, when he "noticing one bold fellow walking leisurely along in open defiance of our bullets, drew up his faithful Springfield and taking deliberate aim—I fear with malice aforethought and intent to kill—fired. My friend is a good marksman, and as secesh was not seen afterwards, the presumption is that he had an extra hole made through his body." ${ }^{110}$ Soldiers saw this type of action as murder. ${ }^{111}$ Another man, upon witnessing a sharpshooter's success, commented that the shot was "remarkable" even with the aid of a scope, but that he was "thankful to say that every man who witnessed the act pronounced it contemptible and cowardly." 112 The individual targeting of an enemy soldier or killing enemy soldiers who could not defend themselves was crossing the line of "legitimate" death in war.

Even when soldiers did target a particular enemy combatant, they sometimes tried to deny the impact of their shot. Charles B. Haydon wrote on September 17, 1861 he had "some reason to believe that I shot one of them." Having gone to a picket post where there was heavy firing, he borrowed a musket from another soldier, took aim at a Confederate soldier at the edge of a corn field, and fired. The enemy soldier "went down just about the time the ball should have reached him," and several comrades ran over to him. Haydon continued "I am however by no means certain." Later that day he added, "I am confirmed in the belief that I killed the first man I shot at by the fact that a man was seen to be carried away from the place...I am a little surprised

\footnotetext{
${ }^{110}$ Emil Rosenblatt and Ruth Rosenblatt, ed., Hard Marching Every Day: The Civil War Letters of Private William Fisk (Lawrence, KS: University Press of Kansas, 1992): 22.

${ }^{111}$ Drew Gilpin Faust, This Republic of Suffering, 42-43.

112 John G. Perry, June 20, 1864, SoldierStudies.org, accessed December 10, 2012.
} 
myself to see how cool I took it." ${ }^{113}$ While in the end he determined that he had taken a life, and was surprised at his response, initially he distanced himself from that possibility by saying the enemy "went down" and that he was "by no means certain." Even in the end, he did not know for sure that the man was dead, only that a man had been carried away from that location after his shot.

Group absolution and denying responsibility on the basis of following orders were also important tactics used by soldiers to lessen the moral burden on themselves. Soldiers could sometimes deny personal responsibility for killing while acting in a unit where everyone was firing at once. In addition, while individual soldiers might resist killing others, orders from a superior officer relieved them of responsibility in killing enemy soldiers. This placed more pressure upon officers because they were giving orders that would result in the deaths of both the enemy's soldiers and their own - their orders would result in more casualties when their word could also end the fighting — but relieved the private soldiers of some of the individual burden of responsibility for enemy deaths. If given an unpleasant task soldiers could reply as William Jones of the $161^{\text {st }}$ New York Infantry did when ordered to fight on a Sunday, "But it is the soldier's duty to obey implicitly and faithfully." ${ }^{114}$ In addition, acting as a unit to produce enemy casualties increased accountability for comrades (meaning soldiers felt they were protecting their friends which allowed them to kill) and increased anonymity (if killing in a group there was less responsibility for individual deaths). Soldiers also placed responsibility for their actions on the nation and government. If they committed immoral actions in the name of their "just cause" and in service to their country, they could still feel moral while doing the job of a soldier. Historians

\footnotetext{
${ }^{113}$ Charles B. Haydon, For Country, Cause \& Leader: The Civil War Journal of Charles B. Haydon (New York: Ticknor \& Fields, 1993), 90.

${ }^{114}$ William E. Jones, The Military History of the One Hundred and Sixty-first New York Volunteer Infantry, 11.
} 
of later wars suggest that crew operated weapons, such as a cannon, usually had higher rates of fire than individual weapons because the more soldiers working together to produce enemy casualties, the more spread out the guilt becomes (in addition, crew operated weapons are usually operated from a distance which increases the ability to dehumanize the target). ${ }^{115}$

It is also possible that soldiers dealt with the stress of killing by aiming high or choosing to avoid killing in battle, although this can be difficult to prove. A study of World War II soldiers and combat by Brigadier General S. L. A. Marshall entitled Men Against Fire suggests that only about twenty-five percent of soldiers actually fired at the enemy. They would withstand battle and would risk their lives in combat, but did not actually want to fire directly at the enemy. Marshall argues that non-firing soldiers were not a result of demoralization, and the presence of non-firing soldiers added morale strength to the line even without them firing at the enemy. ${ }^{116}$ Under the theory that soldiers prior to Marshall's study also showed low firing rates, Dave Grossman argues that when faced with a stressful situation such as battle, soldiers had the option to fight, flee, submit to the enemy, or posture to relieve the tension of the situation. Fighting is the objective in battle and officers needed their men to fight in order to defend their armies and further their cause through victories, but faced with the prospect of killing and death many soldiers' instincts told them to flee, submit, or posture. Posturing is a coping mechanism for soldiers to deal with the burden of killing other human beings, as is the training and conditioning officers use to reduce posturing and increase active firing on the battlefield against enemy soldiers. Posturing is most often seen in tactics such as using uniforms that accentuate height and size or used colors that would intimidate in battle (for example, the bearskin caps used by British

\footnotetext{
115 Dave Grossman, Lt. Col., On Killing, 149-155; Richard Homes, Acts of War, 24; Reid Mitchell, Civil War Soldiers: Their Expectations and Their Experiences (New York: Viking Penguin Inc., 1988), 80-82.

${ }^{116}$ Dave Grossman, Lt. Col., On Killing, 3-4, 13-19, 36; S. L. A. Marshall, Men Against Fire, 50-66.
} 
grenadiers or the use of red in uniforms that would read well through the smoke of battle), using loud verbal yells to frighten during a battle or a charge (the "Rebel Yell" and Union "huzzah"), using noisy weapons in battle (such as an artillery barrage before an infantry fight that would not kill many enemy soldiers but would frighten, weaken resolve, or convince the enemy to flee or surrender), or firing over an enemy's head to intimidate, but not kill. Studies comparing firing rates and causality numbers, as well as weapons found on the battlefield loaded with multiple rounds, suggest that when faced with living soldiers instead of practice targets, soldiers are less willing to shoot to kill and more likely to aim high and fire over the opponents head. ${ }^{117}$ This may vary due to the situation — a long-range static fight versus a charge or close encounter where a soldier may feel more immediate pressure to defend themselves against fatal harm — but some military historians suggest that relatively low casualty rates in some cases (considering the length of time a battle is fought) suggest that soldiers posture often to intimidate instead of kill. ${ }^{118}$

Beyond battle, another unique coping situation during the Civil War was the experience of capture and time as a prisoner of war. Civil War POWs used many of the same coping mechanisms as they did while in the ranks - religion, amusements, ideas of masculinity and behavior, and pure willpower-but they were disconnected from two of the most important: family and comrades. Captured at the Wilderness in May 1864, Charles Mattocks spent time in POW camps at Lynchburg, VA, Macon, GA, and Charleston, SC before being exchanged in 1865 in time for the final campaign of the war. Throughout his prison narrative he is able to keep

\footnotetext{
${ }^{117}$ Gregory Coco includes in his work A Strange and Blighted Land an article from the Adams Sentinel and General Advertiser from February 9, 1864 about "Arms Gathered on the Field of Gettysburg" that states that of the 28,000 muskets gathered on the battlefield " 24,000 were found to be loaded, 12,000 containing two loads, and 6,000 from three to ten loads. In many instances half a dozen balls were driven in on a single charge of powder." This suggests that men were loading their weapons but not firing, whether because of the confusion of battle or reluctance to kill. Gregory Coco, A Strange and Blighted Land: Gettysburg: The Aftermath of a Battle (Gettysburg, Thomas Publications, 1995), 336.

${ }^{118}$ Dave Grossman, Lt. Col., On Killing, 6-12, 21-29.
} 
his spirits up with activities such as learning German from fellow prisoners, although he often complained about the idle and boring experience of enduring prison. The main two themes that lowered his spirits were the constant hope for and denial of exchange and the absence of letters from family. He wrote home constantly, just as he did while in the ranks, but he never received a reply. On July 4, 1864, two months after his capture, Mattocks wrote in his diary that "I have not heard a word from home. I am all the time worrying, lest they have heard rumor of my being killed, and are still laboring under that delusion...I have written 7 letters and intent to keep it up although I have some doubts of the letters ever reaching their destination." 119 Two more months passed and on September $5^{\text {th }}$ Mattocks marked the four-month anniversary of his capture with the remark "Four months a prisoners and not a word from home." ${ }^{120}$ He continued to write home, hoping that his letters reached his family and always waiting for a reply. Writing to his mother as he entered the fifth month of captivity he lamented that "[w]orse than want of books or of money_-worse than hunger itself,--is the interception of our letters to each other. It has been a habit of so many years to hear from you every week, that I regretfully begin the fifth month without a word of news from home."121

A prisoner's survival depended on the environment of the camp, the skills and tools he brought with him, and the resources he could find within the prison. While some prisoners wrote that the POW experience was a selfish one where one had to do whatever they could to survive, more speak to the crucial importance of social networks to soldier survival. Just as small group connections were crucial to soldiers in the field, prisoners of war often created new groups of comrades who pooled their resources together and supported one another in the camps. Using a

\footnotetext{
${ }^{119}$ Charles Mattocks, “Unspoiled Heart”: The Journal of Charles Mattocks of the $17^{\text {th }}$ Maine, edited by Philip N. Racine (Knoxville: The University of Tennessee Press, 1994), 166.

${ }^{120}$ Charles Mattocks, “Unspoiled Heart," 196.

${ }^{121}$ Charles Mattocks, "Unspoiled Heart," 200.
} 
sample of prisoners from Andersonville National Historic Site's databases, Dora Costa and

Matthew Kahn argue that a prisoner without friends had a smaller chance of survival and the stronger the connection between men the higher the chances became. They theorize that Civil War prisoners of war would have survived at higher rates if they had 150 men from their regiment with them, fifteen members of their company present, a kinsman with them, or the fraction of the company with a sergeant's rank or higher increased by five times. ${ }^{122}$

Prisoners of war quickly recreated the "messes" of the soldier's camp. This was sometimes done on the part of Confederate guards in order to manage the prisoners and distribute supplies, but the men more often created their own alliances with acquaintances or soldiers that were similar to them. In some cases, like that of Charles Smedley and William Griffith from the $90^{\text {th }}$ Pennsylvania Infantry, men from the same unit were captured together and leaned on one another through their imprisonment. Captured at the Wilderness, Smedley and Griffith remained together for the majority of their imprisonment and pooled their resources to gain the supplies they needed. ${ }^{123}$ In other cases, larger groups of prisoners organized themselves in the familiar "mess" system to maintain a sense of normalcy and order. When Abner R. Small was captured before Petersburg and sent to Libby Prison, he and his fellow prisoners quickly organized a "commissary department" with a fellow officer, Colonel Hooper of the $24^{\text {th }}$ Massachusetts Infantry, at its head and he divided the prisoners into messes. Small was the secretary of his mess, No. 6, which consisted of six members of the $39^{\text {th }}$ Massachusetts Infantry

\footnotetext{
122 Dora L. Costa and Matthew E. Kahn, Heroes \& Cowards, 121-154.

${ }^{123}$ Charles Smedley, A Pennsylvania Quaker in Andersonville: The Diary of Charles Smedley. Foreword by James Durkin (Fulton Township, Lancaster County, PA: J. Michael Santarelli and James Durkin, 1995). Smedley and Griffith's capture is described on page 18; an example of them pooling resources for mutual benefit is seen on page 24 when Smedley trades his looking glass for pieces of pine to build a shelter for both men. The last mention of Griffith comes about a month or so before the end of Smedley's diary, about when Smedley was placed in a particular area for very sick prisoners, where he later dies. There is a note early in the diary that Griffith also dies as a prisoner of war
} 
and six members of his own regiment, the $16^{\text {th }}$ Maine Infantry. ${ }^{124}$ In each case, prisoners usually allied themselves with members of their original regiments or soldiers who had some shared identity.

Prisoner "messes" supported each other by combining their skills and resources to better survive the camps. Abner Small inventoried the possessions of his Mess No. 6 as a combined "six tin plates, ten pewter spoons, two tin dippers, seven case-knives, one fork, three jack-knives, and an old stove-hearth..." that they used to cook dinner for the mess members. ${ }^{125}$ Small and his comrades traded, borrowed, and sold items to provide provisions for members of their mess. On Thanksgiving Day in 1864, he remembered that the Massachusetts men within his mess raised money by selling rings and other possessions to buy provisions to make a vegetable soup to celebrate. The other half of the men, the Maine officers, watched in envy until one of Small's comrades sold a ring for thirty-five dollars and Small borrowed rice and bought molasses in order to make a makeshift "pudding." 126 Even outside their messes and small groups, soldiers relied on their networks to barter and trade for needed supplies. In a diary entry, Charles Smedley explains that he sold a loaf of bread and meat for twenty-five cents and bought an onion with that money to make a soup. He does the same the following day, selling food that he could easily consume in order to buy onions, presumably to ward off scurvy which was affecting many of the prisoners. ${ }^{127}$ Abner Small's "old stove-health" became a well-desired commodity within the prison and he "felt honored, but cried with shame, when an enterprising colonel sent his compliments and requested the loan of our stove-health." 128 The shame he expressed was due to

\footnotetext{
${ }^{124}$ Abner Ralph Small, The Road to Richmond: The Civil War Memoirs of Major Abner R. Small of the Sixteenth Maine Volunteers. Together with the Diary which he kept when he was a Prisoner of War, with an introduction by Earl J. Hess, edited by Harold Adams Small (New York: Fordham University Press, 2000), 161.

${ }^{125}$ Abner Ralph Small, The Road to Richmond, 170.

${ }^{126}$ Abner Ralph Small, The Road to Richmond, 175.

${ }^{127}$ Charles Smedley, A Pennsylvania Quaker in Andersonville, 27.

128 Abner Ralph Small, The Road to Richmond, 170.
} 
the humiliation of seeing United States officers reduced to such conditions, but he understood the necessity of sharing these resources.

Men within messes and prison networks took care of each other. When his tentmate Preston A. Champney fell ill, Amos Stearns wrote about cooking rations for him, doing his washing, and assisting him in getting out to sick call. Because Stearns himself was facing health issues, once Champney died Stearns moved into another mess so he could again be part of a supportive system. ${ }^{129}$ Similarly, Charles Smedley recorded in his diary taking care of several comrades even though he himself was chronically sick. During his time in Andersonville he took care of a Dr. Buckley, a Union surgeon imprisoned in the camp, and described cooking for him, washing and mending his clothes, giving him sponge baths, and trying to carry him out for sick call on an almost daily basis to try to get him admitted to the hospital. ${ }^{130}$ On transport from Andersonville to Macon, Smedley begins to mention a soldier whom he referred to as "Close." The next few pages of the diary tell of a daily ministry to this fellow soldier, even as Smedley was suffering from his own illness. Close died on October 18, 1864 and just six days later Smedley's diary came to an abrupt end, his death following the end of his diary by about three weeks. Even towards the end of his life, Smedley took care of his comrades. Richard Dobbins, a fellow prisoner from the $18^{\text {th }}$ Iowa Infantry, who was assisting in the hospital ward where Smedley died wrote that despite his own illness Smedley gave his food to Close and waited on him attentively until his death, perhaps at a detriment to his own life. ${ }^{131}$

\footnotetext{
${ }^{129}$ Amos Edward Stearns, The Civil War Diary of Amos E. Stearns, A Prisoner at Andersonville (Rutherford, NJ: Fairleigh Dickinson University Press, 1981). Stearns' time with Champney is described in pages 69-75, and Stearns noted his movement to a different mess on page 78.

${ }^{130}$ Charles Smedley, A Pennsylvania Quaker in Andersonville, 36-42.

${ }^{131}$ Charles Smedley, A Pennsylvania Quaker in Andersonville, 43-51.
} 
Having this human connection to one another was about more than just taking care of sick comrades and pooling resources to survive. Men supported each other mentally, emotionally, and psychologically through comradery. Writing while confined in a prison at Danville, VA Major Abner R. Small of the $16^{\text {th }}$ Maine Infantry observed three officers who messed together near him slowly sink into apathy and despair. "They became homesick and disheartened," he wrote and would sit every day with their backs against the wall staring at the floor by his feet. ${ }^{132}$ "[T] hey were dying of nostalgia," he observed, and "[i]t gave me the nightmare to lie down in front of those men, so I resolved to break the spell which held them over the grave." 133 Small decided one morning to rouse them from their depressed stupor and he sat down in front of the three men and stared at the first one intensely until the officer demanded to know what he wanted. The first man roused, Small did the same to the other two men until they were agitated enough to stand and confront him. At that point, the first man had started to sink back into his apathetic state so Small spat in his face, which led to a chase around the barracks. When the excitement had settled, Small explained to the three men the purpose behind his actions. "Perhaps they didn't believe all I said," he recorded, "but they forgave me, and lived. I don't remember what they did to occupy their minds after that; I only know they quit staring at the floor." ${ }^{\prime 34}$ In this case, one man saw fellow officers failing to cope with the monotonous and stressful experience of the prison and put it on himself to bolster their psychological ability to cope successfully and survive.

All of the coping mechanisms examined so far have been those which soldiers used to successfully cope with soldiering and remain in the ranks. However, some soldiers had to

\footnotetext{
132 Abner Ralph Small, The Road to Richmond, 171-172.

${ }^{133}$ Abner Ralph Small, The Road to Richmond, 172.

${ }^{134}$ Abner Ralph Small, The Road to Richmond, 172.
} 
remove themselves from soldiering, either temporarily or permanently, to cope with their wartime experiences. On May 9, 1864, just a few days after he wrote that he would not "act the coward," Wilbur Fisk of the $2^{\text {nd }}$ Vermont found himself straggling during battle. Tired and caught up among other men leaving the lines, Fisk started to "consider myself a straggler, too." He admitted that he was "shamelessly demoralized," that he "didn't know where my regiment had gone to, and to be candid about it, I didn't care. I was tired almost to death, and as hungry as a wolf. I had been fighting to the best of my ability for Uncle Sam's Constitution, and now I thought it of about as much importance to me individually, to pay a little attention to my own." 135 Officers tried to halt the stragglers from retreating from the front lines, but Fisk saw fresh troops arriving on the field and continued in his plan to find a safe place to rest. "I should have been ashamed of such conduct at any other time," Fisk wrote, "but just then all I thought of was a cup of coffee, and a dinner of hard tack. The regiment might have been ordered into another battle, and every man of them been killed, and I shouldn't have been ashamed that I wasn’t with them. My patriotism was well nigh used up, and so was I, till I had had some refreshments. I made a deep impression on my haversack, which nourished my fighting qualities so that I could return to my regiment." ${ }^{136}$ Fisk was not a new soldier in 1864, having served in the war since 1861 and reenlisting in 1863 . He had fought in many battles and spoke derisively about cowards and stragglers in his letters home to the Green Mountain Freeman. Yet, despite his years of experience, he too became a straggler during the Battle of Spotsylvania.

One way humans react to a stressful situation is to take direct action against the stressor, which in some cases means removing themselves from that situation. ${ }^{137}$ In the Civil War,

\footnotetext{
${ }^{135}$ Emil Rosenblatt and Ruth Rosenblatt, ed., Hard Marching Every Day, 217.

136 Ibid.

${ }^{137}$ Richard Holmes, Acts of War, 223-230.
} 
removal from the stresses of warfare took three forms: straggling, malingering, and desertion. Some men removed themselves from their unit temporarily, to forage for needed supplies, run away from battle, or recover from an illness or injury at home or away from camp. Straggling was the least extreme of the three and usually meant that men fell out of ranks due to physical or emotional fatigue on the march or in battle. Wilbur Fisk's experiences at Spotsylvania best represent straggling because his self-removal from combat was temporary, due to demoralization and physical fatigue, and did not prevent him from returning to his unit afterwards to continue his duty as a soldier. Malingering was a more complex way soldiers removed themselves from their wartime duties because in these cases soldiers often faked an impairment, either physical or mental, to avoid undesirable duty. The goal of malingering was either temporary or permanent removal from the army. ${ }^{138}$ In one example, James Scott of the $23^{\text {rd }}$ Wisconsin Infantry complained to his sister that several comrades were being discharged, including one Haughawout who Scott claimed was a malingerer. Haughawout and a second soldier, named Dunphey, both claimed to be sick and stayed at a place called Nicholasville under the care of doctors. Finding the rations at the hospital not to their liking these two men would leave the hospital, go find food in the nearby country, and return. After a few weeks, the head surgeon threatened to treat them as deserters since it was clear they were not really ill as first claimed and they returned to the regiment. When they rejoined their comrades at Memphis, they continued the ruse that they were sick but "the boys laughed Dunphey out of it so he has went to work and his duty as easy as any one," but Haughawout continued his ruse and they left him at a hospital at Memphis awaiting discharge. Scott hoped that this malingerer would get a discharge for he was "the greatest old

\footnotetext{
${ }^{138}$ Steven J. Ramold, Baring the Iron Hand: Discipline in the Union Army (DeKalb: Northern Illinois University Press, 2010), 181-184; Eric T. Dean, Jr. Shook Over Hell, 127-128; Robert Fantina, Desertion and the American Soldier, 1776-2006 (New York: Algora Publishing, 2006), 65-66.
} 
maid of a fellow I ever saw in my life" and "we are all tired of his whining." 139 As in this case, some soldiers used a hospital stay as temporary relief from the demands of soldiering and others sought a discharge from the army to secure permanent removal from the war. In other cases, "accidents" or self-mutilation—often self-inflicted wounds to hands, fingers, or feet—were other ways to malinger or remove oneself from duty. ${ }^{140}$

In cases of straggling or malingering, soldiers risked the charge of cowardice or the reputation that they lacked the moral or physical fortitude to fulfill their duty. In both cases, however, soldiers operated under the idea that they could avoid duty while maintaining their masculinity because they retained their identity as a soldier and physically remained in the army, or used a medical excuse to avoid duty. Civil War soldiers saw their military service as a test of their manhood and a responsibility to their nation. Their identity as men led them to balance reputation with self-preservation through strategies such as straggling and malingering. Their additional identity as citizen-soldiers also sometimes led soldiers to balk against the discipline imposed on them in the army. Part of being a citizen-solder was the requirement of selfdiscipline - the idea that each man would maintain their own proper behavior and perform well in battle without the need for an authority figure - and the expectation that they remained independent men who could negotiate the terms of their contract in the same way they did in civilian life.

Private soldiers tried to retain elements of that independence during their wartime service, including rebelling against authority or leaving the army if they felt that the conditions of their service — such as pay, supplies, and length of service — did not match what they were

\footnotetext{
${ }^{139}$ Letter from James Scott to Sister, December 20, 1862, Memphis, TN. SoldierStudies.org. Accessed October 24, 2016.

${ }^{140}$ Eric T. Dean, Jr. Shook Over Hell, 127-128; Robert Fantina, Desertion and the American Soldier, 65-66; Steven J. Ramold, Baring the Iron Hand, 187-189.
} 
promised. ${ }^{141}$ Absolom A. Harrison wrote his wife from Nashville in April 1862 that there had been several "insurrections" within his regiment over the issues of pay and lack of arms. Most of the companies had refused to march from Bardsville to Nashville because they had not received their pay, but they were convinced to march to Munfordville where they received money, but again refused to move because they had not yet received their weapons. In desperation the Colonel acquired guns that had been refused by other units and convinced his men that they would receive better arms when they reached their next stop. However, when they reached the next town those new weapons were not forthcoming and Harrison wrote that they were ordered to march again with his company (the only one that had not mutinied) in the lead. "But they told him plainly they would not go any farther without better arms," Harrison stated, "and I have heard that there is no more arms to give our to cavalry. I do not know what will be the result." 142 In this case, soldiers believed that missing pay and lack of proper weaponry to use in battle breached the contract of their service and allowed them to demand better conditions or refuse to work. Soldiers also disliked any threat to their status as volunteer citizen-soldiers. In July 1865, a few months after the end of the war, James Peters Elliott of the $1^{\text {st }}$ Connecticut Heavy Artillery wrote to his mother that " 144 men of the regiment refused to drill this week and they were arrested for mutiny and sent to Castle Thunder at Richmond. I am sorry for it but the men are getting homesick and think they have done their part." ${ }^{143}$ Retained in service after the war was over, soldiers questioned why they were still soldiers. As citizen-soldiers their military status was temporary and they volunteered to serve until the threat was over. Now that the war had

\footnotetext{
${ }^{141}$ Steven J. Ramold, Baring the Iron Hand, 43-63; Paul Foos, A Short, Offhand, Killing Affair: Soldiers and Social Conflict During the Mexican-American War (Chapel Hill: University of North Carolina Press, 2002), 87-93, 100101.

${ }^{142}$ Absolom A. Harrison to Wife, April 9, 1862, Nashville, TN. SoldierStudies.org. Accessed October 24, 2016.

${ }^{143}$ James Peters Elliott to Mother, July 1, 1865, Depot Semmes, Virginia. SoldierStudies.org. Accessed October 24, 2016.
} 
finished, soldiers waiting for their muster out balked against any extension of their time in the military. Unfortunately for Elliott's comrades the $1{ }^{\text {st }}$ Connecticut was not mustered out until September of 1865.

Straggling, malingering, and rebelling against authority were all usually temporary actions, but soldiers could also permanently remove themselves from service by deserting. Removing themselves from battle or going home without leave were extreme elements of "selfcare" because they carried the harshest penalties, but if there was no other way to relieve the stress desertion was a coping option. Provost Marshal General James Fry estimated there were approximately 200,000 deserters between 1863 and 1865, the time he held that office. The number of desertions would be higher, because many men deserted more than once. Records indicate that the monthly average number of deserters during the war was 5,500 men, with the peak occurring in October 1864 with 10,692 deserters. A report published after World War I stated that the rate of desertion during the Civil War was forty-five percent, the highest rate of any United States war. It is hard to know if these statistics are accurate, however; records during the Civil War are often incorrect or incomplete and it is difficult to determine who deserted and who was absent from the ranks for a variety of different reasons. Some were marked deserters mistakenly because they were given leave by an officer who had no authority to do so, they were missing from an action or recovering in a hospital and their whereabouts were unknown, or they were given leave to go home and recover and could not make it back to their unit on time (this was a particular issue with soldiers suffering from mental illness). ${ }^{144}$

Civil War officers viewed desertion as threat to discipline and morale in the army. However, soldiers who deserted probably did so for a variety of reasons outside pure cowardice.

${ }^{144}$ Eric T. Dean, Jr., Shook Over Hell, 127-128; Robert Fantina, Desertion and the American Soldier, 65-66. 
Lack of support from homefront communities, familial problems back home, poor food, clothing, and weapons, military defeat or low morale, and problems with pay or bounties were all reasons soldiers deserted their units during the war. Even though the Union army and many civilians agreed that desertion hurt the northern cause, and there was policy in place to punish deserters, there was also an understanding that the hardships of war and the needs of families at home might cause a man to desert either permanently or temporarily. Historian Robert Fantina argues that desertion was not necessarily caused by cowardice, but by the human need for selfpreservation. When faced with battle and the hardships of soldiering, Civil War volunteer soldiers had little training, poor leadership, and inadequate supplies. Under these conditions, it makes perfect sense that soldiers would remove themselves from battle or the army to ensure their survival, find needed supplies, or recover at home from injury, illness, or mental stress. ${ }^{145}$ Soldiers used these coping tools to meet their individual needs during the war; each soldier created their own methods for coping with soldiering and maintaining their mental and physical health. Because the official system was unable to fully care for soldiers suffering from mental stress or insanity, soldiers relied on their personal "self-care" options to maintain mental health. Relying on the support of fellow soldiers and officers, soldiers tried to recreate their civilian world within the environment of war. By creating "families" among their messmates, soldiers formed bonds of mutual dependence and support they could lean on. Along with utilizing ideas of family to manage wartime experiences, soldiers clung to their civilian and societal identities by continuing to use concepts of religion, death and mourning, masculinity,

\footnotetext{
${ }^{145}$ Ella Lonn, Desertion During the Civil War (New York: The Century Co., 1928), v, 127-142; Mark A. Weitz, More Damning than Slaughter: Desertion in the Confederate Army (Lincoln, NE: University of Nebraska Press, 2005), xvii; Robert Fantina, Desertion and the American Soldier, 68, 75-76; R. Gregory Lande, Madness, Malingering, and Malfeasance, 44-50.
} 
and courage. Soldiers also used amusements, alcohol, distancing themselves from the enemy and death, training, and desertion to relieve the stress of soldiering.

For those soldiers who found the limits of their personal "self-care" coping, the official medical system could only provide some relief. As discussed in the previous chapter, the understanding of mental trauma and treatment options available to Civil War soldiers were limited and primarily focused on physical or moral causation rather than connecting insanity to war trauma. Civil War soldiers who broke down under the mental strain of warfarewhose well had run dry in Dave Grossman's analogy_-faced an uncertain future. Many whose stress resulted in insanity remained in insane asylums for a period of time, sometimes for the rest of their lives. For others, the mental trauma of war and the limits to their "self-care" and medical options followed them home and haunted them and their families in the post-war period. When the fighting was done and soldiers returned to their homes, both veterans, families, physicians, and the government would analyze the war and the impact it had on soldiers. In the post-war period official understandings of mental illness did not change, and soldiers again relied on comrades to cope. 


\section{Chapter 4:}

"Disqualified from Procuring Their Own Maintenance...by reasons of wounds...or sickness":

\section{Government and Medical Treatment of Insane Soldiers in the Post-War Period}

On April 21, 1865, just days after General Robert E. Lee's surrender and President Abraham Lincoln's assassination, a young soldier was admitted to Longview State Hospital. The twenty-five year old soldier had developed the "first symptoms of mental aberration" during his time in the army, enough so to secure a discharge and return home to his family. His condition unimproved, his family brought him to Longview, with the soldier's consent, and he was considered a well-behaved young man. The case files state that he was "mild and amiable" as well as "dignified and honorable, conscientious, [and] trustworthy." "The admitting physicians observed that a prominent symptom of his insanity was "that he felt that the whole responsibility and management of the war was on himself," however they determined that the condition was connected to scrofulous diathesis—a constitutional state prone to inflammation —and spinal irritation, in addition to hereditary. ${ }^{2}$ The case notes that an "aunt was once insane, these facts went far to prove the hereditary tendency of the disease." Because this patient was seen as trustworthy he was allowed a razor to shave himself - usually against the policy of the asylumand within four hours of admission had cut his throat in an attempted suicide. Surviving the initial attempt, the Longview staff tried to save him, but he grew violent and injured an attendant before passing away from his suicide attempt just forty-eight hours after arriving at the asylum. ${ }^{4}$

\footnotetext{
${ }^{1}$ Ohio Historical Society, Longview State Hospital, Case History of Male and Female Patients, 1863-1918, (Call \#: State Archives Series 541) (BV4389), page 77.

${ }^{2}$ Ibid.

${ }^{3}$ Ibid.

${ }^{4}$ Ibid.
} 
The Civil War transformed the United States in many ways, but the potential lessons about warfare and mental trauma went unnoticed. Transitioning into the post-war period, insanity in soldiers such as the one described above was still interpreted as caused by heredity, physical illness, or moral weakness. When Longview physicians diagnosed this young man with insanity caused by a constitutional state, spinal irritation, and heredity they followed the same formula seen during the war, and asylum cases well into the Gilded Age reflect the same patterns. Outside of the asylums, society and the government legitimated and supported soldiers with visible, physical wounds of war with programs to give prostheses to amputees, give employment preference to veterans, award pensions to those disabled by disease or wounds during the war, and house veterans who could not support themselves. These support options were part of a new welfare state that considered "martial citizenship," the concept that veterans had gained a special citizenship that separated them from other Americans through service to the state. For Americans, coming to the defense of the nation was the ultimate test of citizenship and the loss of health or limb in service to that nation meant that the country was obligated to care for them. In all these programs, the emphasis remained on physical wounds and soldiers suffering from mental ailments connected to their service experienced the same limited options that they did during the war. Beyond prosthesis, federal employment, and pensions, the incorporation of veterans back into society was left to the soldiers and their communities. ${ }^{5}$ For the most part, the emphasis for causation, definition, and treatment in veterans remained on physical and moral causes, and there was no drastic change in the understanding of insanity due to the war.

Once the war ended, Union soldiers had to transition from warfront to homefront and reclaim the identity of civilian. Many historians such as Paul Cimbala argue that most veterans

\footnotetext{
5 Patrick J. Kelly, Creating a National Home: Building the Veterans' Welfare State, 1860-1900 (Cambridge, MA: Harvard University Press, 1997), 2-5, 56-57, 133-140.
} 
were able to reclaim their civilian lives and become productive members of society in the postwar years. For these men their wartime experiences did not alienate them from their families or their communities and they entered a post-war society that honored and commemorated their service to the nation. For most veterans, Cimbala claims, the meaning behind their service made those sacrifices worthwhile, stating that "[e]motionally, they still found self-worth in what they had done and...they understood that their war had given their lives special meaning. Thus old soldiers in memoirs and histories, through the activities of veterans' organizations, and in communal memorial celebrations still found outlets for their patriotism as they fought new battles to control the memory of the war." ${ }^{, 6}$ Eager to return home at the end of the war, both soldiers and civilians shared fears about the transition back into society but for most soldiers, Cimbala argues, the readjustment to civilian life went smoothly. Soldiers understood themselves as citizens first and saw the transition from war as returning to their normal state. Veterans returned home wanting to take up previous employment and education put on hold by the conflict. While some could resume their previous jobs, those who were physically disabled by the war had to find new employment or seek assistance from the government. The adaption of these veterans to new forms of self-support shows their resilience, argues Cimbala, and demonstrates that the Republican ideology of success to hard-working, determined, and sober men was still prevalent in American society. ${ }^{7}$

Families and communities welcomed veterans home with open arms because they understood the purpose of their service in the army. Union soldiers returned home in victory, bolstering them up because they knew their sacrifices, and the loss of comrades and loved ones,

\footnotetext{
${ }^{6}$ Paul A. Cimbala, Veterans North and South: The Transition from Soldier to Civilian After the American Civil War (Santa Barbara, CA: Praeger, 2015), xv.

${ }^{7}$ Paul A. Cimbala, Veterans North and South, 83-93.
} 
contributed to a purpose. Because veterans saw their service through this positive lens of patriotism, honor, nobility, morality, and service to their nation they understood their sacrifice as part of a moral and political victory. This optimism and the support of their communities allowed soldiers to return home and settle back into civilian life. ${ }^{8}$ Families were important in the transition from soldier to civilian. Family members could affirm the veteran's service and assign value to the sacrifices he made for the nation. Family also provided homes, employment, and a sense of normalcy for veterans, giving them time to find new jobs, resume the education or employment they left during the war, or begin their own households and families. Some soldiers did not have access to this family support, facing broken families due to the tension of a longdistance relationship or experiencing trouble settling down. In addition, soldiers whose family supported different politics or sides during the war and soldiers who served without the approval of their families faced difficulty gaining validation of their service from home. Overall, however, Cimbala argues that the majority of veterans were able to transition back into their families and communities without problems. ${ }^{9}$

Transformed by their wartime experiences, in reality, veterans had varying amounts of success coping with their experiences after the war. Returning home, soldiers found that the war they experienced, and were changed by, was different than the war experienced by civilians at home. ${ }^{10}$ The experience of coping in the post-war period was as individualized as the process during the war, as individual as the veterans themselves. While some returning soldiers were able to return to their normal lives with only some interruptions, others were completely incapacitated, either physically or mentally, by their experiences during the war. As traumatized

\footnotetext{
${ }^{8}$ Paul A. Cimbala, Veterans North and South, 17-40, 107-131.

${ }^{9}$ Paul A. Cimbala, Veterans North and South, 47-67.

${ }^{10}$ Gerald F. Linderman, Embattled Courage: The Experience of Combat in the American Civil War (New York: The Free Press, 1987), 1.
} 
soldiers transitioned into the civilian world, entered insane asylums, and applied for pensions they found that ideas of mental trauma and insanity remained focused on physical and moral causation. As Brian Jordan states, veterans were "suspended between the dead and the living, the rest of their days were disturbed by memories of the war." ${ }^{11}$ Even veterans who successfully transitioned could exhibit signs of trauma. As during the war years, veterans reacted to their experiences along a spectrum; many veterans were able to live productive lives after the war while dealing with the memories of their service, while many others were incapacitated by their wartime experiences, spending the rest of their lives in asylums or unable to fully escape their memories. Wherever veterans fell along this spectrum in the post-war years, they struggled to understand the trial they had survived and searched for support among their communities and comrades. The experience of war had changed them fundamentally, and they could not escape that. Pennsylvanian James J. Creigh explained that " $[\mathrm{w}]$ ith our own eyes, with our own ears, we have seen and heard something of the great conflict... Its reminiscences are interwoven with the lives of every one of us." 12 John Haley of the $17^{\text {th }}$ Maine echoed these sentiments when he wrote "My bruises are inward." ${ }^{\prime 3}$ While many veterans did transition successfully, other failed to leave the war behind.

Some of these veterans are found in asylum records in the post-war years. One soldier affected by sunstroke near Savage Station in June 1862 returned home unable to do much manual work in support of his family because of dizziness and trouble with his head. ${ }^{14}$ Five years after he testified for his pension, he was admitted to Utica State Hospital for "Chronic Mania"

\footnotetext{
${ }^{11}$ Brian Matthew Jordan, Marching Home: Union Veterans and Their Unending Civil War (New York: Liveright Publishing Corporation, 2015), 4.

12 Brian Matthew Jordan, Marching Home, 73.

13 Ibid (emphasis Haley's).

${ }^{14}$ When soldier identities are not revealed it is due to confidentiality requirements held by archives in order to uphold HIPPA regulations.
} 
caused by his sunstroke. On admittance, this soldier was "laboring under the delusion that persons are pursuing him, and laying plots to waylay and injure him. He imagines that he hears voices and persons talking to him from a distance when left alone or not spoken to + keeps muttering to himself or an imaginary person and looking behind him as though expecting someone to spring upon him." ${ }^{15}$ One of the admitting certificates stated that the sunstroke caused the patient to be "queer" since his time in the army and another physician testified that the veteran suffered from loss of memory and hallucinations such as "fears of personal injury from friends + engaging in imaginary battles." ${ }^{16}$ At the time of his admission, he was suspicious of the people around him, had tried to cut a piece of his foot off to "show he was a true man," was depressed, had contemplated suicide, and was listed as attempting homicide. ${ }^{17}$

Another soldier, admitted to Columbus State Hospital in 1866, came home physically broken down from his time in the army. An 1891 affidavit in his pension file testified that the veteran was "not only constitutionally broken down but was not right in his mind and is not to this day. He has been twice since the war sent to the Asylum for Insane at Columbus Ohio..."18 This case is one of the few where physicians attributed insanity to wartime service, acknowledging that there was no hereditary cause, attributing the insanity to "excitement in battle," and recording that the veteran has "forebodings of injury." 19 In a 1900 declaration, the veteran himself wrote that he was still physically broken down and suffering from rheumatism as

\footnotetext{
${ }^{15}$ Pension certificate 368040. National Archives, Washington, D.C.; New York State Archives, New York Office of Mental Health, Utica State Hospital Patient Case Files, 1843-1898 (14231-96), Volume 70, Entry 3.

16 Ibid.

${ }^{17}$ Ibid.

${ }^{18}$ Pension application 963748 and certificate 728956. National Archives, Washington, D.C.

${ }^{19}$ Ohio Historical Society, Columbus State Hospital, Admission Books, 1838-1868 (call \#: State Archives Series 896) (BV7215), page 230.
} 
well as "extreme nervousness" to the extent that he could not perform manual labor and at times could barely take care of himself. ${ }^{20}$

When a veteran of the $128^{\text {th }}$ New York Infantry was admitted into Utica State Hospital the physician recorded evidence of an extremely nervous and paranoid mind. Copying from the physician statement to commit this former soldier to the asylum, the patient record states that the patient rambled and talked incoherently, had frequent delusions and hallucinations, and was paranoid that his neighbors constantly watched him and were a danger to his wife. This veteran felt the need to guard his wife to and from her workplace because he feared his neighbors would take her for their own and he was generally listless and unable to work. In addition, he "at times becomes violent and dangerous, threatening his family and destroying the furniture in the house and is always denouncing and threatening his neighbor." ${ }^{21}$ All three of these cases demonstrate long lasting mental illness in these veterans, often resulting in numerous confinements in asylums through the rest of their lives.

When traumatized veterans returned home, the burden fell heavily on the family to care for them and prevent them from harming themselves or others. As Jeffrey McClurken points out in his book on Confederate veterans, although many of his subjects showed signs of mental illness or trauma, not everyone ended up in an asylum. As was the tradition before the asylum system was put into place, many families cared for physically and mentally affected veterans in their homes, only sending the mentally ill to asylums in cases where they could not care for them, they were violent, or they wandered away from home often. While McClurken saw an

\footnotetext{
${ }^{20}$ Pension application 963748 and certificate 728956. National Archives, Washington, D.C.

${ }^{21}$ New York State Archives. New York Office of Mental Health, Utica State Hospital Patient Case Files, 1843-1898 (14231-96), vol. 78, entry 45.
} 
increased number of families relying on the state for help caring for the insane after the war, there were still many families who cared for loved ones within the home. ${ }^{22}$

These veterans fit uneasily into their homes. On June 5,1865 , the surgeon of the $196^{\text {th }}$ Ohio Infantry wrote a letter sending one of the regiment's officers home on account of lunacy, writing "I do not think his case one which demands an asylum, but a change of life from Camp to that of home and family to ensure speedy recovery. ${ }^{.23}$ A comrade was charged to bring the soldier to Marysville, Ohio the next day and the officer was promptly admitted into Columbus State Hospital for "excitement in military matters." ${ }^{24} \mathrm{He}$ remained in the asylum for six or seven months and then returned home. Despite leaving the asylum his inability to perform manual labor, his poor memory, and propensity for nervous prostration left him shut up in his home and placed much of the burden on his wife to run household and business affairs. He rarely left home, lived "in continuous dread of something dreadful impending," and often became confused. ${ }^{25}$ A surgeon reported in 1875 for the soldier's pension claim that he "has to be watched over by his family not from fear of danger but to avoid excitement and a consequent disturbance of the mind which is feeble and impaired." 26

Families and neighbors commented on the state of returned veterans who seemed odd or unable to transition. Oliver Perry Newberry's wife complained that he drank, was cross and "impossible" to live with, and was doing nothing to support his family. Newberry wrote that he tried to replace thoughts of the war with thoughts of home, but the memories kept nagging at

\footnotetext{
${ }^{22}$ Jeffrey W. McClurken, Take Care of the Living: Reconstructing Confederate Veteran Families in Virginia (Charlottesville: University of Virginia Press, 2009), 118.

${ }^{23}$ Pension application 228578 and certificate 181091, widow's pension application 719924 and certificate 496011. National Archives, Washington, D.C.

${ }^{24}$ Ohio Historical Society, Columbus State Hospital, Admission Books, 1838-1868 (call\#: State Archives Series 896) (BV7215), entry \#4431, page 151.

${ }^{25}$ Pension application 228578 and certificate 181091, widow's pension application 719924 and certificate 496011 . National Archives, Washington, D.C.

${ }^{26}$ Ibid.
} 
him. "Cool reason runs dethroned and anarchy and confusion reigns supreme, where common sense should be chief ruler," Newberry admitted, "strange thoughts run my head crazy."27 Sarah McLean wrote to her son Edgar in July 1865 about one returned veteran who "has come home crazy...He thinks there is going to be another campaign...that seems to be the impression he is laboring under." ${ }^{28}$ Patrick Cleary, who boarded with his brother-in-law, John Spain, along with another veteran named William Cunningham, was known to act strangely after the war. In the early 1870s, it was noted that Cleary would ramble about generals and officers and talk incoherently while neglecting his farm work. Cunningham was woken regularly by an agitated Cleary at night, and Cleary often taught military drill to a white bulldog behind the barn where he had pounded a row of stakes into the ground as an "enemy." 29

Besides the burden of caring for a mentally insane veteran, new behaviors placed stress on familial ties. John Burns of the $108^{\text {th }}$ New York Infantry was admitted to the Government Hospital for the Insane (GHI) from a Baltimore hospital in October 1864 with acute mania and discharged less than a year later, recovered. Just a few months later Burns was in a County Asylum for two months before being transferred to Utica State Hospital where he spent the rest of his life. The officer transferring Burns to the Utica Asylum reported that the patient "spoke of a spirit within his body directing him to do everything he did. It at the time told him to kill his wife \&c. At times it swears at him. Has done no work since May last. At times he accuses his wife of infidelity. ${ }^{\prime 30}$ Another soldier who was admitted into Utica State Hospital in 1892 stated

\footnotetext{
${ }^{27}$ Brian Matthew Jordan, Marching Home, 70. Emphasis Newberry's.

${ }^{28}$ Brian Matthew Jordan, Marching Home, 69.

${ }^{29}$ Brian Matthew Jordan, Marching Home, 70.

${ }^{30}$ John Burns, pension application 108357, certificate 85404. National Archives, Washington, D.C.; Annual Report of the Adjutant-General of the State of New York for the Year 1903. Registers of the One Hundred and Seventh, One Hundred and Eighth, One Hundred and Ninth, One Hundred and Tenth, One Hundred and Eleventh, One Hundred and Twelfth and One Hundred and Thirteenth Regiments of Infantry. Transmitted to the Legislature January, 1904 (Albany: Oliver A. Quayle, State Legislative Printer, 1904), 189.

dmna.ny.giv/historic/rehist/civil/rosters/Infantry/108th_Infantry_CW_Roster.pdf. (February 23, 2015)
} 
that he was sent there "because he could not agree with his wife. She opposed him in everything relating to the farm work. He threatened her and said she was not fit to live and ought to be killed. He did not intend to kill her. Talked harshly to his children sometimes. He freely admitted the above." He was discharged after two months and listed as recovered. ${ }^{31}$

William V. Gardiner of the $22^{\text {nd }}$ New York Cavalry suffered a sunstroke at the Battle of the Wilderness which manifested in insanity in early 1865 , causing him to be admitted to the GHI until June of that year. When he returned home he married a woman named Catherine whom he did not know prior to or during the war and she testified that she had no knowledge of his ailments when she married him. Testifying for William's pension in 1907 she remembered, “... at first he was not so bad he kept growing worse, he would imagine people were plotting to kill him, he would get jealous of me, he had no cause for jealousness, if a man passed the house and looked toward it he would be jealous. He would talk strange...he threatened to kill me often, I stood everything on account of the children, towards the last he would strike me."32 Neighbors took notice of Gardiner's odd behavior, one testifying that he would "put his hand to his head and say I am not right...I got afraid of him and ordered my men to keep him out of the storehouse." 33 An altercation with neighbors eventually led to Gardiner's arrest and confinement to an asylum, where he had been for around twenty years at the time his wife testified for a pension. ${ }^{34}$

\footnotetext{
${ }^{31}$ Pension certificate 72220. National Archives, Washington, D.C.; New York State Archives, New York Office of Mental Health, Utica State Hospital Patient Case Files, 1843-1898 (14231-96), volume 88, entry 9.

${ }^{32}$ William V. Gardiner, pension application 363852 and certificate 1132728, widow pension (Catherine Gardiner) application 923783 and certificate 688393. National Archives, Washington, D.C.

${ }^{33}$ Ibid.

${ }^{34}$ William V. Gardiner, pension application 363852 and certificate 1132728, widow pension (Catherine Gardiner) application 923783 and certificate 688393. National Archives, Washington, D.C.; Annual Report of the AdjutantGeneral of the State of New York for the Year 1894. Volume V. Registers of the 20 ${ }^{\text {th }}, 21^{\text {st }}, 22 d, 23 d, 24^{\text {th }}, 25^{\text {th }}$ and $26^{\text {th }}$ Regiments of Cavalry, New York Volunteers in War of the Rebellion. Transmitted to the Legislature January 2, 1895 (Albany: James B. Lyon, State Printers, 1895), 561. dmna.ny.gov/historic/reghist/civil/rosters/cavalry/22ndCavCW_Roster.pdf. (January 28, 2015).
} 
In some cases, veterans went missing and families did not know the fate or location of their loved ones after the war. "Would you kindly let me know by mail if Patrick Cannon ever applied for a pension if so did he receive one and if so is he dead or alive I have not seen him since $1871 \ldots$... pleads a Mrs. Cannon in a letter included in Patrick Cannon's pension file. ${ }^{35}$ While he had been discharged for insanity in October 1863 from the $115^{\text {th }}$ New York Infantry, Patrick reenlisted in 1864 and filed for a pension for a gunshot wound to his left arm during service with the $25^{\text {th }}$ New York Cavalry. It is unknown from the pension file whether Mrs. Cannon ever reunited with Patrick before his death in 1913 at the New York State Soldiers and Sailors Home, but her letter is evidence of the struggle some veterans and families faced in the post-war period. ${ }^{36}$

An interesting case comes from an Ohio family after the soldier resided in Longview State Hospital for several months in 1863 after becoming insane in the service. When admitted he was "laboring under the delusion that people seek his life, set traps for him in the street and about his house, and that everybody hears his conversation with his family." His speech was disconnected, he was frequently excited, and would rarely sit still, but he apparently recovered rapidly under the asylum's care and was discharged. He would make his way back to an asylum at least once more, admitted into Eastern Lunatic Asylum in Lexington, Kentucky in 1872 where they recorded that this was his second bout of insanity, the first "produced in our opinion by exposure and service in the Federal Army." Two years later, the soldier escaped from the asylum and made his way to Cincinnati where his wife found him in 1877 and brought him home. In

\footnotetext{
${ }^{35}$ Patrick Cannon, pension application 115488, certificate 81734. National Archives, Washington, D.C.

${ }^{36}$ Patrick Cannon, pension application 115488, certificate 81734. National Archives, Washington, D.C.; Annual Report of the Adjutant-General of the State of New York For the Year 1903. Registers of the One Hundred and Fourteenth, One Hundred and Fifteenth, One Hundred and Sixteenth, One Hundred and Eighteenth, One Hundred and Nineteenth and One Hundred and Twentieth Regiments of Infantry. Transmitted to the Legislature January, 1904 (Albany: Oliver A. Quayle, State Legislative Printer, 1904), 175. dmna.ny.gov/historic/reghist/civil/rosters/Infantry/115th_Infantry_CW_Roster.pdf. (February 23, 2015).
} 
1878, he had a fit of angry insanity where he struck his wife with a chair; he was sent to a work house and she took her children and moved in with family. After 1879, he left town and his wife did not hear from him. The wife filed for a widow's pension in 1895 , believing that her husband was dead. She had received word from a man named Taylor that her husband had died around 1881 after jumping off a bridge in St. Louis during a fit of insanity. Her initial claim was rejected on the grounds that proof that the soldier was dead was not satisfactory. Unbeknownst to her, the soldier was still alive and submitted his own invalid pension claim around 1900 for the inability to support himself due to varicose veins, poor eyesight, and old age. In his pension application he stated that he was married with two children, but that he "had not seen or heard of wife or children for more than 20 years past last saw them in Cincinnati Ohio more than 20 years ago." The soldier died at Cook County Hospital in Chicago in November 1901 and his wife received the requested widow pension in $1902 .{ }^{37}$

Many soldiers struggled with being disconnected from their families and coping with their wartime experiences, sometimes to a fatal degree. When one New York soldier returned home in 1865 , he did not remain home for long, leaving without warning for eight or nine years with no word to his family. He returned then for about a year and left again, returning in 1881 . Upon this second return his family welcomed him back, but the soldier found that he could not agree with his wife and preferred to live alone. "He left his wife, not because of any quarrel, but because he could not seem to agree with her and he wanted to be alone when he 'felt blue,"' noted his asylum file. ${ }^{38}$ "Periods of depression were frequent with him, but when he had, and

\footnotetext{
${ }^{37}$ Pension application 1254377 and certificate 1020361, widow's pension application 335031 and certificate 546095. National Archives, Washington, D.C.; Ohio Historical Society, Longview State Hospital, Case History of Male and Female Patients, 1863-1918 (Call \#: State Archives Series 541) (BV4389), page 3.

${ }^{38}$ New York State Archives, New York Office of Mental Health, Utica State Hospital Patient Case Files, 1843-1898 (14231-96), volume 82, entry 105.
} 
was able to take work, he was cheerful. ${ }^{39}$ Two weeks before this veteran's admission into Utica State Hospital he cut his arm and thigh, walked into a lake, and took laudanum in order to commit suicide, but survived. ${ }^{40}$ This case exhibits a veteran who has insomnia, depression, difficulty working steadily, and trouble connection with his family. His mention of "feeling blue" reflects the same terminology used by soldiers during the war to mark when they were feeling the mental effects of the war and in this case his struggles led to an attempt at his life.

The number of veterans who attempted to commit suicide will probably never be known, but it was one way veterans coped with their experiences in the post-war period. Dennis W. Brandt offers a unique look into a post-war suicide and its wartime roots in his work Pathway to Hell which examines the wartime service and mental trauma of Angelo Craspey. ${ }^{41}$ Beyond Craspey's well-documented story, the suicides of veterans go largely un-examined, found sporadically in diaries, newspapers, and other records. Tragedy in Gideon Welles' family was recorded in the Secretary of the Navy's diary when his nephew, Robert G. Welles, killed himself in December 1866. A veteran who had served the entire war, experienced fourteen large battles, was wounded at Gettysburg, and was promoted to captain in the Regulars, Robert leaned heavily on his brother, Sam, for support after the war. When Sam died suddenly, Robert grew depressed and spent his days in melancholy seclusion until the night when he "shot himself through the head in his father's library and in the presence of his father. He placed his arm around his father's neck, kissed him, exclaimed farewell, and committed the act." ${ }^{\prime 2}$ Newspapers also sometimes printed the suicides of veterans; the March 18, 1866 suicide of John Rabus was

\footnotetext{
${ }^{39}$ Ibid.

${ }^{40}$ Ibid.

${ }^{41}$ Dennis W. Brandt, Pathway to Hell: A Tragedy of the American Civil War (Lincoln: University of Nebraska Press, 2010).

${ }^{42}$ Gideon Welles, "Diary of Gideon Welles, December, 1866," in Diary of Gideon Welles, Secretary of the Navy under Lincoln and Johnson, Vol. II. Edgar Thaddeus Welles, ed. (Boston, MA: Houghton, Mifflin \& Co., 1911), 651-652. American Civil War: Letters and Diaries, accessed February 4, 2011, (Welles:D1982-32).
} 
published in Harper's Weekly in early April. In a suicide note found in his room, the former member of the $15^{\text {th }}$ New York Heavy Artillery wrote that he contracted palsy in the service and could not work to support himself, thus he applied for a pension. His pension application must have been unsuccessful because he wrote in his farewell that "[n]ot receiving any support from the government, this is to inform my friends and acquaintances I have been obliged to kill myself." ${ }^{43}$ Forty years old when he had enlisted in 1863, Rabus was discharged for disability in September 1865 at Mower General Hospital in Philadelphia. ${ }^{44}$ In this rare case with a suicide note of explanation, the inability to support himself in the aftermath of his service led him to the final decision of suicide. While there is no extensive study of suicide in veterans, there is evidence that suicidality was a problem in the post-war period. In Eric T. Dean, Jr.'s study of Indiana veterans in asylums, he found that 149 of his case subjects (fifty-one percent) either contemplated or committed suicide, or were marked as "suicidal" at their commitment. In his study he found that soldiers who were suffering from purely psychological problems, those who suffered from gunshot wounds during the war which caused chronic and severe pain, and veterans who suffered with illnesses contracted during the war that eventually led to psychological problems were the most likely to be suicidal. ${ }^{45}$

Many veterans who had been admitted into an asylum during the war or experienced trouble transitioning in the post-war period found themselves in an asylum after the war, either periodically or permanently if families could not take care of them. It is difficult to find most of

\footnotetext{
43 "Domestic Intelligence: News Items," Harper's Weekly, April 7, 1866, 222. HarpWeek, Accessed February 4, 2011.

${ }^{44}$ Annual Report of the Adjutant-General of the State of New York. For the Year 1897. Registers of the Fifteenth and Sixteenth Artillery in the War of the Rebellion (New York and Albany: Wynkoop Hallenbeck Crawford Co., State Printers, 1898), 289. http://dmna.ny.gov/historic/reghist/civil/rosters/Artillery/15thArtCW_Roster.pdf. (January 30, 2017).

${ }^{45}$ Eric T. Dean, Jr., Shook Over Hell: Post-Traumatic Stress, Vietnam, and the Civil War (Cambridge, MA: Harvard University Press, 1997), 151.
} 
them, however, because physicians and asylum personnel continued to avoid connecting the patient's insanity with their military service. Unless there was a physical ailment resulting from service that was considered a possible causation for the insanity, very often the medical records of asylums did not mention military service unless the patient provided that information in his own history that was recorded on admission or, in a few cases, the patient had been transferred directly to the asylum from the army. This means that veterans who spent time in asylums, either for a short period or for the rest of their lives, go underrepresented in post-war studies because their veteran status is often not noted in their records. ${ }^{46}$

In the decades after the Civil War, the medical field experienced a revolution, partly based on the lessons learned during that conflict. Both the former Confederate States and the United States collected detailed records from army surgeons and medical personnel to learn from the experiences of the Civil War, which were recorded in the Medical and Surgical History of the War of the Rebellion. In addition, the discovery of antisepsis by Lister directly after the war, and the resulting development of bacteriology, pushed an advance in medicine. The records kept during the Civil War show a marked change towards a more scientific approach to medicine; diagnosis based on experimentation, observation, and the use of record keeping instead of on the traditional four humors. The late-nineteenth century, beginning around 1870, also saw the rise of research in the field of neurology and new information about the nervous system. During this period the medical meaning of "trauma" was central to debates concerning physical or mental causation of ailments such as "railway spine," thought by some to be a concussion of the spinal

\footnotetext{
${ }^{46}$ Beyond noticing this in my own research in asylum records, Diane Miller Sommerville notes this research dilemma in her article, "Will They Ever Be Able to Forget?: Confederate Soldiers and Mental Illness in the Defeated South," in Weirding the War: Stories from the Civil War's Ragged Edges, edited by Stephen Berry (Athens: The University of Georgia Press, 2011), 324-325. She argues that this may be partially caused by physicians wanting to protect the masculinity and pride of veterans by not connecting their mental illness to breaking down during the war.
} 
cord caused by industrial accidents. Some historians argue that the period between 1870 and 1930 paired the rise of technological modernity with the study of how these changes affected the humans experiencing it. ${ }^{47}$ While experiences that could be considered "traumatic" had always occurred, argue Paul Lerner and Mark Micale, in the early twentieth century "psychological trauma acquired the status of a disease entity with a technical terminology, theories of causation, a classification, and therapeutic systems as well as medico-legal standing and government recognition." 48

Within this change in medicine the treatment of insanity did undergo a transition during the mid-nineteenth century, however the lessons of the Civil War in that respect went largely unlearned. Large numbers of chronic or incurable patients challenged the previous optimism of curability. In the five years of the Civil War, the population of the United States grew two percent but the insane population doubled, and it would double again every ten years for the rest of the century. ${ }^{49}$ In addition, a new generation of psychiatrists was far more committed to somatic understandings of mental illness. ${ }^{50}$ While the asylums of the early-nineteenth century were built on the optimistic assumption that mental illness was curable, by the mid- and latecentury those assumptions were largely challenged. In reality, many patients did not recover, asylums treated only a small percentage of the mentally ill in the country, and most hospitals

\footnotetext{
${ }^{47}$ Paul Lerner and Mark S. Micale, "Trauma, Psychiatry, and History: A Conceptual and Historiographical Introduction," in Traumatic Pasts: History, Psychiatry, and Trauma in the Modern Age, 1870-1930, edited by Mark S. Micale and Paul Lerner (Cambridge: Cambridge University Press, 2001), 9-11; Ira M. Rutkow, Bleeding Blue and Gray: Civil War Surgery and the Evolution of American Medicine (New York: Random House, 2005), 40-41; Alfred Jay Bollet, Civil War Medicine: Challenges and Triumphs (Tuscon, AZ: Galen Press, LTD, 2002), 37-42.

${ }^{48}$ Paul Lerner and Mark S. Micale, "Trauma, Psychiatry, and History," 11.

${ }^{49}$ R. Gregory Lande, Madness, Malingering, and Malfeasance: The Transformation of Psychiatry and the Law in the Civil War Era (Washington, D.C.: Brassey's, Inc., 2003), 195.

${ }^{50}$ Gerald N. Grob, The Mad Among Us: A History of the Care of America's Mentally Ill (New York: The Free Press, 1994), 105-128; Norman Dain, Concepts of Insanity in the United States, 1789-1865 (New Brunswick, NJ: Rutgers University Press, 1964), 84-112; David J. Rothman, The Discovery of the Asylum: Social Order and Disorder in the New Republic (Boston: Little, Brown and Company, 1971), 237-238.
} 
discharged unrecovered patients and minimized the numbers because those patients contradicted the claims of curability that physicians continued to believe. ${ }^{51}$

The numbers of insane persons grew in the mid-century, outgrowing the space available in small, therapeutic asylums. There was a rapid increase of patients and asylums in America, with almost 140 hospitals for the insane by 1880 . Increases in the number of incurably insane patients made the public question whether insanity was truly curable, even within the "moral treatment" upheld by asylum superintendents. Returning veterans with their unique challenges also did not always fit comfortably within the established asylum system. One population of chronic patients that grew by 1900 was elderly patients. Previously cared for by their families, the changes in family structure wrought by wage labor and social mobility in the industrial age led to more of the elderly insane being committed for long-term care. At the same time, the almshouse declined as an option for the care of chronic cases and states looked to build institutions to care for the incurably insane or elderly. Historians have offered several arguments for this increase in the insane population within asylums, from an increase in the general population, to families who were more likely to commit an insane relative due to economic pressures on the household in a capitalist economy and the hope that they could be cured, and a rise in service industries available in many facets of society. ${ }^{52}$

The numbers of the insane grew to overwhelm the asylum system and led to institutions turning to a more custodial function to house those who would not get better. While early asylums housed at most 250 patients, by 1866 the members of the AMSAII voted to expand their size to six hundred patients. Moral management, while not dismissed, was no longer feasible

\footnotetext{
${ }^{51}$ Gerald N. Grob, The Mad Among Us, 105-106; Benjamin Reiss, Theaters of Madness: Insane Asylums and Nineteenth-Century American Culture (Chicago: The University of Chicago Press, 2008), 169-172, 191.

${ }^{52}$ Carla Yanni, The Architecture of Madness: Insane Asylums in the United States (Minneapolis: University of Minnesota Press, 2007), 105-106.
} 
with the large numbers of patients treated in asylums. Psychiatrists continued to use daily routines, good diets, exercise, and entertainments to help their patients, but moral management with its personal attention and space for amusements and work inside and outside the asylum building was impractical with the increased number of patients. Despite these changes, asylum psychiatrists still claimed moral treatment, particularly the necessity of an organized and soothing asylum setting. While time and resources were more limited due to large numbers of patients, many of them chronically insane, psychiatrists still believed in environmental determinism..$^{53}$

The majority of patients in the post-war period were cared for in public, state-run institutions rather than private asylums. Private hospitals spent more per patient and gave greater privacy and luxury on the basis that their patients, largely from higher class families who could afford to pay for private institutionalization, were more accustomed to those things. Wealthy families chose private asylums to ensure that their relatives were surrounded with the comforts they were familiar with to ensure their recovery. Private institutions could limit the number of patients and were not overcrowded like their public counterparts. ${ }^{54}$ On the other hand, public institutions struggled to maintain their previous standards of care. Public institutions maintained the core elements of moral treatment architecture in their designs; the superintendent remained in a central tower with patients arranged in proximity to the center based on their behavior with space for amusements and an overall pleasant style of architecture and landscaping. In creating new public institutions, they tried to maintain the previous standards of design and function while expanding the building to hold hundreds of patients. ${ }^{55}$ Eventually the demands of a high

\footnotetext{
${ }^{53}$ Carla Yanni, The Architecture of Madness, 105-106.

${ }^{54}$ Carla Yanni, The Architecture of Madness, 106-107.

${ }^{55}$ Carla Yanni, The Architecture of Madness, 111-122.
} 
number of patients caused the shift from large, linear asylums based on the Kirkbride plan to a cottage system with multiple buildings to house patients. Moral treatment depended on a small attendant to patient ratio, about one to fifteen, but it was nearly impossible to keep that ratio as asylums grew to house hundreds of patients. ${ }^{56}$

In New York, for example, appropriations for the state hospital at Utica doubled while the number of cured patients fell, leading to a commissioned survey which revealed that many incurable insane persons were stuck in poorhouses. Because these patients would not benefit from the "moral treatment" available at the asylum in Utica, the state opened Willard Asylum for the Chronic Insane in 1869. While the institution at Utica would continue to treat acute cases with the hopes of curability, Willard Asylum would house the incurably insane at the minimum expense needed to provide comfortable and humane care in the long-term. The ASMAII did not support the Willard Asylum because it undermined the essence of the Kirkbride plan, but its implementation shows that the public no longer looked to the traditional superintendents for guidance and believed that institutions should meet the needs of the patients. In the decades after the Civil War most asylums gradually turned from "moral treatment" to more custodial care and lost much of their reformatory character, although some elements of that previous theory remained. With these changes physicians also had to reevaluate their role. Within the traditional asylum, physicians were trained to treat the pathology of insanity, which was-in theorycurable. With the decline of optimism about curability and the rise of the custodial institution, physicians and staff lost much of their purpose and became more negative. Public support also waned and public opinion changed towards more negative associations with asylums. ${ }^{57}$

\footnotetext{
${ }^{56}$ Carla Yanni, The Architecture of Madness, 138-142.

${ }^{57}$ John Albert Pitts, "The Association of Medical Superintendents of American Institutions for the Insane, 18441892: A Case Study of Specialism in American Medicine," (Ph.D. Dissertation: University of Pennsylvania, 1979),
} 
In the period after the Civil War, as asylums expanded in size, so too did social criticism and official oversight. With numbers of insane patients rising, particularly the chronic insane, society questioned whether asylums were actually treating and curing their patients. Growing asylums also required increased funding from the state which lead to new oversight and regulation of these hospitals by state agencies and committees. Tighter bureaucracy gave asylums less freedom and put pressure on asylum psychiatrists and staff to conform to social ideas of care. Attempts to "centralize" asylums, and the resulting legal and administrative changes, undermined the original goals of the institutions. ${ }^{58}$ The AMSAII, in the center of these changes and calls to reform the system, largely dismissed the criticism, preferring to stay with their established methods. As a result, the authority of asylum superintendents steadily declined in the 1870 s and 1880 s and the ASMAII lost much of its standing in the eyes of the public. In its place, new medical psychologists and neurologists, following the scientific revolution occurring in medicine, developed new treatment methods to address the insane in the later part of the nineteenth century. Younger physicians were less committed to the idea of curability and favored state institutions to treat acute and chronic cases separately and more effectively. ${ }^{59}$

By the turn of the century, the large asylums were viewed as opulent and wasteful, and critics questioned the very foundation of curability within the asylum system. Practitioners within the new field of neurology attacked the asylum system for its emphasis on architecture and environment rather than on scientific and medical inquiry into mental illness. The new scientific approach to medicine encouraged research into the causation and treatment of mental

108-114; Benjamin Reiss, Theaters of Madness, 169-172; David J. Rothman, The Discovery of the Asylum, 237-238; Gerald N. Grob, The Mad Among Us, 114-128.

${ }^{58}$ Gerald N. Grob, Mental Institutions in America: Social Policy to 1875 (New York: The Free Press, 1973), 258263.

59 John Albert Pitts, “The Association of Medical Superintendents of American Institutions for the Insane," 80-101, 158-187; Benjamin Reiss, Theaters of Madness, 169-172; Gerald N. Grob, The Mad Among Us, 109-110. 
ailments, rather than the management of their patients. ${ }^{60}$ The rising belief among neurologists, including S. Weir Mitchell, was that the path to curing the mind was to cure the body. Dedication to moral treatment declined and asylums became warehouses for the chronically ill while doctors conducted scientific research in office and labs. In addition, the pioneers of asylum psychiatry were fading from the scene. In 1888 the AMSAII rejected Kirkbride's construction plans and four year later the AMSAII became the American Medico-Psychological Association. By the end of the century the era of moral treatment had passed. ${ }^{61}$

While moral treatment faded from the scene, the commitment to physical and moral causation of insanity strengthened in the post-war period. Dr. William Hammand, who served as Surgeon General during the war and supported the research of S. Weir Mitchell at Turner's Lane was one who spoke against the treatment of the insane within asylums. ${ }^{62}$ In 1883 , while president of the American Neurological Association (ANA), he published a Treatise on Insanity in its Medical Relations. In this work he connected mental illness with the physical state of the brain, arguing that healthy brains equaled healthy minds and diseased brains, diseased minds. "In individuals whose brains are well-formed, free from structural changes, and are nourished with a due supply — neither excessive nor deficient — of healthy blood," Hammond wrote, "the perception, the intellect, the emotions, and the will act in a manner which within certain limits is common to mankind in general." ${ }^{63}$ Slight changes to the structure or nourishment of the brain could cause slight alterations to its faculties, and large changes could produce more extreme mental changes. He acknowledged that every brain was different either "inherent in the individual, reaching him through a long line of ancestors, or...acquired through the action of

\footnotetext{
${ }^{60}$ Carla Yanni, The Architecture of Madness, 105,

${ }^{61}$ Carla Yanni, The Architecture of Madness, 142-144.

${ }^{62}$ Carla Yanni, The Architecture of Madness, 143.

${ }^{63}$ William A. Hammond, A Treatise on Insanity in its Medical Relations (New York: Arno Press, 1973$), 35$.
} 
extraneous influences upon him; or, again, they may be such as normally act upon him in the due and regular course of his life." ${ }^{\prime 64}$ These differences in the brain led to differences in the mind, and an individuality to how each person's mind worked.

In this treatise, he divided the human mind into four categories which he defined as the "organic constitution dependent upon certain mental or physical peculiarities" which affect a person's predisposition to illness. ${ }^{65}$ These four parts - the perception, intellect, emotions, and will—reflect the division of the body into four under Galenic medicine. How the four parts of the brain interact determined the person's temperament, which Hammond also divided into four categories. Those with a "sanguine temperament" were active, with strong circulatory and respiratory systems, and bright minds. This group was physically characterized by red hair and blue eyes, and was most susceptible to acute mania. The "lymphatic or phlegmatic temperament" is the opposite of the "sanguine temperament," characterized by green or grey eyes and light hair. These people are less vivacious than the "sanguine temperament" and are, as Hammond puts it, "soft," "flabby," and "slow." This group is more likely to suffer from acute mania and melancholia. Those with darker complexions and firm, determined, and decisive minds fall under the "choleric or bilious temperament," and are more subject to insanity, particularly melancholia and suicidal or homicidal derangement. The weakest temperament, and seemingly most susceptible to mental illness according to Hammond, was the "nervous temperament" of pale, thin, and easily fatigued people. This group was likely to suffer from neuralgia, hysteria, insanity, and other diseases existing in their own imagination. ${ }^{66}$

\footnotetext{
${ }^{64}$ William A. Hammond, A Treatise on Insanity, 37.

${ }^{65}$ William A. Hammond, A Treatise on Insanity, 61.

${ }^{66}$ William A. Hammond, A Treatise on Insanity, 15-34, 63-74.
} 
Ultimately, the constitution of a person was crucial to the chance they would suffer some form of mental illness. A weak constitution increased the likelihood of mental illness, while a strong constitution lessened the chances and increased the probability of recovery if the person did fall mentally ill. ${ }^{67}$ While physical and mental constitution do have an effect on a person's susceptibility to mental and physical illness, Hammond's trait-based categories demonstrate that medical professionals still held traditional standards for diagnosing mental illness. Hammond's work was touted as a work of "advanced physiological psychology" and his position at the head of the ANA lent authority to his research, although some British reviewers disagreed on his assessment that insane individuals should be treated outside of asylums. ${ }^{68}$

Asylum records in the post-war period show that physicians continued to ascribe to physical or moral causation for insanity. James Boland, who during the war had shot at a colonel thinking he was the Holy Ghost, was sent to the GHI for three months in 1864 and then sent home “improved." Despite the asylum's optimism at Boland's condition, his wife would later declare, "He came home a changed man. Was not right when he returned but I struggled along with him hoping for improvement but he grew worse..." ${ }^{69}$ A neighbor testified that Boland "came home crazy and I remember our crowd of boys were often badly frightened and scampered home when we would see him with an old shovel or pick standing guard and drilling on the sts. He would halt us and demand the countersign. He was a terror to us."70 Boland's wife consented to commit him to an asylum. According to his physician's affidavit he was an inmate at Renssalear County Lunatic Asylum June 12, 1865 to January 8, 1867, September 12, 1870 to

\footnotetext{
${ }^{67}$ William A. Hammond, A Treatise on Insanity, 63-74.

68 "Review: A Treatise on Insanity In Its Medical Relations by William A. Hammond," The British Medical Journal 1, 1204 (January 26, 1884): 170-171.

${ }^{69}$ Widow's pension (Sarah Boland; soldier, James Boland) application 330809, certificate 267889. National Archives, Washington, D.C.

${ }^{70}$ Ibid.
} 
December 5, 1871, and October 3, 1872 to June 8, 1873 before he was admitted to Willard State Asylum in 1873. When Boland died in the asylum in 1881, the case record stated the cause of death as "Chronic Hepatitis" and a case of "hereditary insanity hastened by intemperate habits." In the post-war period Boland's insanity was considered a result of both hereditary and his "intemperate habits," instead of the war when his condition first manifested. Now a widow, Sarah Boland argued that James had died from insanity caused by the war and claimed a widow's pension in the late 1880 s. $^{71}$

The case of a soldier from the $95^{\text {th }}$ New York Infantry shows both evidence of a veteran struggling after the war and how asylum personnel interpreted his ailment. When the forty-seven year old veteran was admitted into Utica State Hospital the physician recorded both his Civil War service and a head injury from falling off a horse at the age of fifteen. The record then notes heavy abuse of alcohol, morphine, and tobacco, as well as run-ins with the law due to larceny charges. While the record focuses on his physical health—mentioning poor general health, kidney and heart disease, and "smothering sensations about the heart" that echo the idea of "soldier's heart"- there are hints about his mental state as well. The patient record, taken from the patient's own testimony, mentions that the veteran could not sleep without using opium and listed insomnia among the ailments adding to his physical ill health. ${ }^{72}$ In addition, a later 1895 physician affidavit for the veteran's pension — that revealed that this man had left Utica, had been confined in the St. Lawrence State Hospital at Ogdensburg, and was then housed with a familytestified that the soldier was "very nervous and excitable, the family with whom he makes his home informs me that said [soldier] is restless and uneasy, sleepless and suspicious, always on

\footnotetext{
${ }^{71}$ Ibid.

${ }^{72}$ New York State Archives. New York Office of Mental Health. Utica State Hospital Patient Case Files, 1843-1898 (14231-96), vol. 74, entry 38.
} 
the move, and walking about from place to place almost constantly."73 Despite the evidence of substance abuse, insomnia, and other indications of a troubled mental state, the physician admitting this veteran into Utica State Hospital focused on the patient's drug and alcohol habits as well as the physical injury suffered at fifteen, recording the supposed cause of this veteran's insanity as "it is supposed that the injury to the head received in youth rendered him more susceptible to the baneful effects of stimulants."74 Not only did the asylum physicians focus on moral and physical causation in this case, the veteran received a pension for a gunshot wound to the jaw, an injury to his right hand, and rheumatism. Despite evidence in the asylum and pension records that this veteran spent time in at least three insane asylums, the pension application claimed only the physical ailments related to his wartime service. ${ }^{75}$

Soldiers not only suffered from psychological ailments in the post-war period, they presented those disabilities to the government for support through the expanding pension system. The government offered disabled veterans benefits additional to any back pay or bonuses due to them in three main ways. Soldiers with amputated limbs were offered free prostheses and support to fit and care for the artificial limbs. In addition, soldiers were given preference in government jobs to assist them in economic self-sufficiency. Finally, soldiers were offered federal pensions. The Civil War pension system was an enormous endeavor to match the scale of the Union army. Over two million men served in the Union's army and navy, and the war created such a high number of veterans and family survivors that the government had to put an expansive system in place to care for the volunteers who had answered the nation's need. With the initial call to arms in 1861 , the government put in place a temporary solution to care for these first

\footnotetext{
${ }^{73}$ Pension certificate 805977. National Archives, Washington, D.C.

${ }^{74}$ New York State Archives. New York Office of Mental Health. Utica State Hospital Patient Case Files, $1843-1898$ (14231-96), vol. 74, entry 38.

${ }^{75}$ Pension certificate 805977. National Archives, Washington, D.C.
} 
volunteer regiments, extending regular army benefits to cover those fighting in the early months of the war. With the expansion of the army and the realization that the war would not be over within the first year, the government had to create a system to specifically provide care for veterans and survivors of Union regiments. ${ }^{76}$

The Pension Act of 1862 created such a system to support Civil War volunteer soldiers. This system supported soldiers permanently disabled due to their military service and also extended that support to family survivors of deceased soldiers. Widows had been allowed pensions under the previous system as well, but this new law also allowed mothers and orphaned children to claim aid. Pensions under this system were connected to either death, disability, or disabling disease contracted in the line of duty while serving the United States, and pension applications had to prove both disability and connection to military service. The pension office rated veterans with respect to "total disability" for the performance of manual labor and set base rates of compensation for conditions such as the loss of an arm or an eye in the service. Later, the pension system saw two major shifts. The first, in 1873 with the "Consolidation Act," saw an increase in pension applications made for conditions contracted in the service that had caused disability in the years after the war, and the second, with the Disability Pension Act of 1890, changed the focus from disability to age and length of military service which allowed veterans to apply for pensions simply due to inability to support themselves because of old age. ${ }^{77}$

\footnotetext{
${ }^{76}$ Steven G. Livingston, Student's Guide to Landmark Congressional Laws on Social Security and Welfare (Westport, CT: Greenwood Press, 2002), 19; Theda Skocpol, Protecting Soldiers and Mothers: The Political Origins of Social Policy in the United States (Cambridge, MA: The Belknap Press of Harvard University Press, 1992), 103-107; Peter Blanck, "Civil War Pensions and Disability," Ohio State Law Journal 62, no. 1, Symposium: Facing the Challenges of the ADA: The First Ten Years and Beyond (2001): 117-118.

${ }^{77}$ Steven G. Livingston, Student's Guide, 19-22; Thirty-Seventh Congress, Sess. II. Ch. 165, 166. 162-July 14, 1862, CHPA. CLXVI. "An Act to Grant Pensions." http://drbronsontours.com/pensionsanacttograntpensionsjuly141862.html; Theda Skocpol, Protecting Soldiers and Mothers, 106-130; Peter Blanck, "Civil War Pensions," 117-126.
} 
The Pension Office was established in 1833 and transferred from the War Department to the new Department of the Interior in 1849. By the time of the Civil War, the system's bureaucracy was already well established with regional offices where soldiers and veterans could submit claims under local oversight to prevent fraud. Once a veteran submitted an application for a pension, it was assigned an examiner who first made sure the application was done correctly and contained the needed documentation. The examiner then asked the War Department for a report on the military history of the soldier. If there was insufficient proof within a soldier's military record of the claimed disability, the veteran was then asked to provide testimony from officers and comrades familiar with their service and disability. The examiner then double checked with the War Department that these witnesses were in fact present at the alleged times and places to ensure they were giving accurate testimony. Once the paperwork was in order, the veteran was ordered to appear for an examination by appointed surgeons who evaluated what disability existed, to what degree the disability prohibited them from performing manual labor, whether the disability was caused by military service, the probable duration of the disability, and how the habits of the applicant affected the origin and duration of the disability. These surgeons wrote up surgeon's certificates to be included in the pension file and rated the veteran's disability according to the current rate scale approved by the Pension Office. If the surgeons did not find disability from the alleged cause, the petitioner had one hundred days to provide evidence before their claim was rejected. Once rejected, the applicant had twelve months to supply additional evidence and resubmit their claim. In addition, after 1873 some pensioners were required to submit to biennial follow-up examinations to reassess their disability and pension rate. Many soldiers made use of pension attorneys to navigate this sometimes confusing process. ${ }^{78}$

\footnotetext{
${ }^{78}$ Claudia Linares, “The Civil War Pension Law," (Center for Population Economics Working Paper, University of Chicago, 2001), 9-12.
} 
The established pension process dealt better with physical disability because it was more easily observed and more simply connected to disease or injury associated with military service. Most established pension rates were set for physical ailments, such as the loss of a leg or eye, although pension statistics do include categories such as "nervous prostration," "sunstroke," and "disease of brain, including insanity." ${ }^{.79}$ Mental disability was not always easy to observe or measure in physical terms. Pension applications dealing with mental health matters illuminate the social and cultural ideas about insanity and suicide in the nineteenth century, as well as the continued struggles of soldiers and physicians to define mental conditions related to the war.

While pensioners had to prove disability and connection to military service during the Civil War, pensions were also viewed within political and moral terms by the pension office and wider society. Several historians have argued that the expansion of the pension system in the 1870s and 1880s was largely due to the political influence of organizations such as the Grand Army of the Republic and politicians who were veterans themselves. These political voices argued that the government was obligated to take care of disabled veterans and surviving dependent family members in exchange for their service to the nation, but there was also an expectation that the government was supporting soldiers who had acted honorably and valiantly. Like other welfare programs, pensions were only for the "deserving," those who needed help living an independent and honorable life. The government would only support those who had earned it through honorable service or death in the war, and society expected that veterans would continue being the "righteous core" of the generation, even into their old age. The legitimacy of a pensioner's disability was often linked to questions of moral character or honorable service. ${ }^{80}$

\footnotetext{
${ }^{79}$ Claudia Linares, "The Civil War Pension Law," 14-17; William H. Glasson, Federal Military Pensions in the United States (New York: Oxford University Press, 1918), 138.

${ }^{80}$ Theda Skocpol, Protecting Soldiers and Mothers, 149-151; Charles F. Wooley, The Irritable Heart of Soldiers and the Origins of Anglo-American Cardiology: The U.S. Civil War (1861) to World War I (1918) (Burlington, VT:
} 
Just as they did during the war, veterans often connected mental illness with physical ailments or symptoms in order to understand their disability and legitimize it in the eyes of pension officials. Because the pension system was set up to focus largely on finding physical disability that would prevent a veteran from performing labor to support himself and his family, veterans suffering from mental disabilities after the war often tried to connect their insanity or trauma to physical causes or symptoms. One pension application by a New York soldier while an inmate of Utica State Hospital claimed sunstroke, Typhoid Fever, chronic Diarrhea and "resulting insanity" connecting his insanity to the ailments he suffered in August 1862 near Antietam. ${ }^{81}$ A soldier from Ohio claimed his pension for "Insanity from hardships + exposures at Elk River Tenn." in June 1864, which he clarified in his declaration as "over exertion + heat." $\$ 2$ The pension application of Fernando Richards alleged "brain fever inducing insanity" resulting from being sick with measles and falling to exposure and fatigue. ${ }^{83}$ William Grogan of the $99^{\text {th }}$ New York Infantry was treated at the GHI during the war and was in and out of asylums in the post-war period; testimony in his application claimed that his insanity resulted from a wound to the hand and taking sick due to "exposures and privations" on the march. ${ }^{84}$ In the case of William Barton of the $12^{\text {th }}$ New Jersey, the pension application claimed the soldier had "contracted some affection of the head" from exposure and hardships that resulted eventually in epilepsy and "softening of the brain." Barton had been home sick on leave in 1862 with his "nervous system" a "complete wreck" which resulted in his arrest and admission into a

\footnotetext{
Ashgate Publishing Company, 2002), 40; James Marten, Sing Not War: The Lives of Union \& Confederate Veterans in Gilded Age America (Chapel Hill: The University of North Carolina Press, 2011), 220-221; Peter Blanck, "Civil War Pensions," 133-134; Larry M. Logue, Race, Ethnicity, and Disability: Veterans and Benefits in Post-Civil War America (New York: Cambridge University Press, 2010), 19-21, 31-32.

${ }^{81}$ Pension application 872453 and certificate 603468. National Archives, Washington, D.C.

${ }^{82}$ Pension application 185109, certificate 140569 and widow's pension application 323055, certificate 218049 . National Archives, Washington, D.C.

${ }^{83}$ Fernando Richards, pension application 30613. National Archives, Washington, D.C.

${ }^{84}$ William Grogan pension application 69101, certificate 207025. National Archives, Washington, D.C.
} 
Philadelphia hospital when he could not return to duty. ${ }^{85}$ Many pension files for soldiers who had suffered some degree of insanity during the war contain claims or references to disease, the elements, or other physical symptoms and causes. As seen during the war years, soldiers framed their mental conditions in more easily understood physical terms and recognized that physical conditions were considered more legitimate.

Just as in wartime, sunstroke remained a popular cause referenced in pension applications. One New Yorker in Utica State Hospital blamed sunstroke for his insanity, filing a claim for "vertigo, headache and insanity results of sunstroke." 86 In the case of a soldier from the $77^{\text {th }}$ Ohio Infantry, two severe sunstrokes while on march in Tennessee caused him to lose his mind in 1862 when he was discharged and committed to Columbus State Hospital. This veteran was transferred to several different hospitals during his lifetime and by the 1890s was residing with his family, kept in a "jail" within the family home. Mostly quiet, the veteran obsessively bathed every day and needed everything done in threes (i.e. three cups of coffee). The chronic mania exhibited by this veteran to the end of his life was continually blamed on sunstroke through his pension records. ${ }^{87}$

Beyond disease and the elements soldiers and physicians sought to connect insanity with physical trauma as well. Theodore Geer was admitted into the GHI December 6, 1864 from Forest Hall prison for acute mania. While the superintendent of the GHI stated that there was no evidence as to the cause of the insanity, "unless his having been a prisoner may be considered a cause," the surgeon's certificate written in 1877 for the pension application focused on a wound

\footnotetext{
${ }^{85}$ William Barton pension application 764907 and certificate 555375, widow application (Jennie) 759294 and certificate 54719. National Archives, Washington, D.C.; Record of Officers and Men of New Jersey in the Civil War, 1861-1865. Volume I. Compiled in the Office of the Adjutant General. William S. Stryker, Adjutant General (Trenton, NJ: John L. Murphy, Steam Book and Job Printer, 1876), 600.

${ }^{86}$ Pension certificate 368040. National Archives, Washington, D.C.

${ }^{87}$ Pension application 41875, certificate 141596. National Archives, Washington, D.C.; Ohio Historical Society, Columbus State Hospital, Admission Books, 1838-1868 (call \#: State Archives Series 896) (BV7215) \#4028.
} 
to Geer's right forearm which had been shattered by a shell fragment. As for the insanity, the "shock or concussion produced by the explosion has affected his brain to such an extent, that his mind has become greatly impaired." For the surgeons examining Geer, the insanity was a result of the physical concussion of the shell burst affecting his brain. ${ }^{88}$ Similarly, when an Ohio soldier was admitted into Columbus State Hospital in 1868 the cause was listed as "fright and injury from bursting of a shell which injured his spine." His pension claim, however, focused on disease as the cause of his insanity. ${ }^{89}$ Both of these cases foreshadow the idea of "shell shock" in World War I.

Soldiers were sometimes adamant that they were not mentally disabled, whether out of pride or believing that a physical ailment would be more successful in a pension claim. George Bolsinger, whose officer thought he was "playing off" when he did not appear for a gunboat expedition, ended up in an insane asylum at least one more time after the war. During his hospital stay, his son and appointed guardian, William, submitted a pension application claiming insanity caused by sunstroke. When George was discharged from the Kansas asylum after a two year stay he was adamant that the pension application submitted by his son was fraudulent. He instead submitted an application based on rheumatism and a shell wound to the shoulder, stating "That is all I claim for. I have never made any other claim + never authorized anybody to apply for any other disability. My mind is all right now, only I feel more duller than I did before."90

In some cases, soldiers' pension claims did not even mention insanity in their claims, either because their mental affliction had been short-lived or because they did not wish to make a claim upon mental illness. William H. H. Bradbury of the $40^{\text {th }}$ New York Infantry was

\footnotetext{
${ }^{88}$ Theodore O. Geer pension application 57526, certificate 89090. National Archives, Washington, D.C. ${ }^{89}$ Ohio Historical Society, Columbus State Hospital, Admission Books, 1838-1868 (Call\#: State Archives Series 896) (BV7215) \#4970; pension application 135176, certificate 119177. National Archives, Washington, D.C. ${ }^{90}$ George Bolsinger pension application 594088 and certificate 586593. National Archives, Washington, D.C.
} 
discharged in March 1862 "in consequence of insanity," but by the time he made a claim for a pension in 1890 he only listed lung trouble as his disability. ${ }^{91}$ Robert Ramsey of the $67^{\text {th }}$ New York was discharged in 1863 from the GHI but requested a pension for a gunshot wound to the hip and resulting running sore. ${ }^{92}$ Veterans and physicians still struggled to understand mental ailments resulting from the war, and just as treatments during the war largely focused on physical aspects, pension claims did as well. Veterans who could demonstrate a physical disability, either separate from or connected to their mental ailment, were usually more successful in gaining a pension than veterans or families who applied for aid on purely mental disabilities or trauma. ${ }^{93}$

As veterans and the families of deceased soldiers sought pensions from the federal government, relatives of soldiers who committed suicide during the war faced a unique challenge. Caught between the death of their loved one during the war and the political and cultural understandings of both the pension system and suicide, these applicants had to navigate nineteenth-century America's social ideas about insanity, suicide, and a proper soldier's death. While both suicide and insanity became more sympathetic conditions in the nineteenth century because of shifts toward medicalization and the religiously-based reform movements of the period, there was a marked difference in the social acceptability of each. Suicide was still a cultural and moral taboo while insanity was accepted as a treatable medical condition. This distinction affected the ability of families to claim pensions for relatives who had committed suicide during the war. Suicide was not considered an honorable death for soldiers, but suicide

\footnotetext{
${ }^{91}$ William H. H. Bradbury pension application 962384 and certificate 729283, widow (Clara) application 944806 and certificate 706813. National Archives, Washington, D.C.

${ }^{92}$ Robert Ramsey pension application 634414, certificate 410575 and widow pension (Margaret) application 566869, certificate 375430. National Archives, Washington, D.C.

${ }^{93}$ Eric T. Dean, Jr., Shook Over Hell, 146-149.
} 
under insanity was more socially acceptable because these men were suffering under a recognized medical ailment at the time of their death.

On June 12, 1862, H. Holmes sent a military telegram to "Friend Phillips" that opened with "I have sad news to tell you, your brother is dead..."94 Albert Phillips of the Oneida Independent Company Cavalry had committed suicide that morning by shooting himself through the heart with a pistol. Albert's mother submitted a pension request that included depositions from one of Albert's officers and the telegram sent by Holmes, both of which explained that Phillips had been unwell for several days before the incident and had been acting strangely the night before his death. Holmes wrote in his telegram that Phillips had been sick and the death of a comrade in the hospital seemed to affect him greatly, and the $2^{\text {nd }}$ Lieutenant of the Oneida Company declared that Phillips must have been operating under mental derangement when he killed himself. ${ }^{95}$ Despite their efforts, Catherine Phillips' pension application was rejected on the grounds that her son's death was a suicide and "that the soldier was insane is not established." 96

Pension officials looked for evidence of insanity in suicide cases. "[I]f the appellant can file...testimony showing that her late husband committed suicide while laboring under a fit of insanity occasioned by sickness incurred in the service and line of duty, such testimony will, of course, be duly considered by this office... until such testimony is presented, it is submitted that the claim should remain on the rejected files." ${ }^{.97}$ This February 20, 1883 letter from the Pension Office to the Secretary of the Interior, refers to the rejected pension application of Jane Wellington and her two young daughters. Jane's husband, Kimball, who mustered into the $161^{\text {st }}$

\footnotetext{
${ }^{94}$ Mother's pension application (Catherine; soldier Albert Phillips) 99719, National Archives, Washington, D.C.

${ }^{95}$ Ibid.

${ }^{96}$ Ibid.

${ }^{97}$ Widow's pension application (Jane; soldier, Kimball Wellington) 46319, certificate 241261 and minor application 365272, certificate 241262. National Archives, Washington, D.C.
} 
New York Infantry as a musician, committed suicide on June 25, 1863 at a Regimental Hospital in Louisiana. ${ }^{98}$ Left with two infant daughters, Jane filed a pension to support them and remarried to George Brownwell, who was a drunkard and soon left her. Her application was "rejected January 12, 1864, on the ground that as her 'husband's death resulted' from suicide, she was not entitled to pension. ${ }^{999}$ Jane appealed the decision in the 1880 s, writing a letter in February 1883 claiming that Kimball was taken sick in camp, conveyed to the hospital at Baton Rouge, "suffering from a disease which affected his head and caused derangement of his mind," and he committed suicide under that derangement. With her case reopened, Jane supplied testimony from the acting Provost Marshall at Baton Rouge who affirmed that her husband had been insane at the time of his death and evidence from the company books which showed Kimball as "Died June 25, 1863, at Baton Rouge, La, cut his throat; supposed to be crazy and done the deed." 100 Jane's appeal was successful based on the additional evident proving her husband's insane state of mind at the time of his suicide, and she was awarded not only the original minor's pension, but also a widow's pension as well. ${ }^{101}$

Pensions for suicidal soldiers with no evidence of insanity were usually rejected. The application of Eva Woldert after her husband, Adam, hung himself in February 1863 after two months at Satterlee General Hospital for chronic rheumatism was rejected on the grounds that it was a suicide. Both the Surgeon's General report and the Adjutant General's report list Adam

\footnotetext{
${ }^{98}$ Annual Report of the Adjutant-General of the State of New York. For the Year 1904. Registers of the One Hundredth and Fifty-Sixth, One Hundred and Fifty-Seventh, One Hundred and Fifty-Eighth, One Hundred and Fifty-Ninth, One Hundred and Sixtieth, One Hundred and Sixty-First, One Hundred and Sixty-Second, One Hundred and Sixty-Third, One Hundred and Sixty-Fourth, One Hundred and Sixty-Fifth, One Hundred and Sixty-Sixth, and One Hundred and Sixty-Seventh Regiments of Infantry (Albany: Brandow Printing Company, State Legislative Printers, 1905), 804. http://dmna.state.ny.us/historic/reghist/civil/rosters/Infantry/161st_Infantry_CW_Roster.pdf. ${ }^{99}$ Widow's pension application (Jane; soldier, Kimball Wellington) 46319, certificate 241261 and minor application 365272, certificate 241262. National Archives, Washington, D.C.

${ }^{100}$ Ibid.

${ }^{101}$ Ibid.
} 
Woldert as a suicide with no mention of insanity. ${ }^{102}$ The minor application for support of Anna D. Fox, daughter of James Fox, was similarly rejected. When James Fox enlisted in August 1862, his wife, Delia, had just died that February and Anna was two years old. ${ }^{103}$ James died at the battle of Fredericksburg, his death reported in the Adjutant General's report as "committed suicide, December 13, 1862, by shooting himself near Fredericksburg, Va." ${ }^{104}$ Palmer Wood, the family attorney and Anna's legal guardian, tried to argue that James was killed during the battle or that his death was accidental, but the evidence stood against them. Particularly damning was testimony from a captain in the regiment that stated while Fox was found dead on picket duty, meaning it could have been accidental or a suicide, the regiment generally believed he had killed himself and that Fox was "not at the time of his death crazy or out of his head."105

On the contrary, pension applications that proved insanity or mental derangement were far more successful. Matthew Young of the $143^{\text {rd }}$ New York Infantry committed suicide by rigging a gun to the ridge pole of his tent and firing it into his chest using a string to pull the trigger. While a very obvious case of suicide, Matthew's widow collected numerous testimonies from comrades that attested to her husband's mental state at the time of his death. Comrades remembered that within a few months of enlisting, Matthew lost his spirits, lost weight, and became sick. Some testimonies claimed he had become frightened and insane on picket duty, others claimed he worried about eternal punishment of his soul, others remembered he had fallen

\footnotetext{
${ }^{102}$ Record of service of Connecticut men in the army and navy of the United States during the War of Rebellion (Hartford, CT: Press of the Case, Lockwood \& Brainard Co., 1889.), 566. Ancestry.com. Accessed 9 October 2011; Charles D. Page, History of the Fourteenth Regiment, Connecticut Vol. Infantry (Meriden, CT: The Horton Printing Co., 1906), 430; Widow pension (Eva; soldier, Adam Woldert) application 21372. National Archives, Washington, D.C.

${ }^{103}$ Minor pension (for Anna D. Fox; soldier, James Fox) application 17916. National Archives, Washington, D.C.

${ }^{104}$ Annual Report of the Adjutant-General of the State of New York For the Year 1899. Registers of the Twenty-sixth, Twenty-seventh, Twenty-eighth, Twenty-ninth, Thirtieth, Thirty-first and Thirty-second Regiments of Infantry (Albany: James B. Lyon, State Printer, 1900), 925. http://dmna.state.ny.us/historic/reghist/civil/rosters/Infantry/32nd_Infantry_CW_Roster.pdf.

${ }^{105}$ Minor pension (for Anna D. Fox; soldier, James Fox) application 17916. National Archives, Washington, D.C.
} 
ill. In his affidavit, Young's former first lieutenant remembered that he made application for a leave of absence for Young that was denied, causing Young's condition to worsen. All testified that he was insane to some degree prior to his suicide. David Muir testified that Young committed suicide with Muir's gun because his own had been taken from him and David Measten testified that he had been put on watch over Young and had stepped out of the tent temporarily when the suicide occurred. With the mountain of evidence presented for the pension file, the fact that Young was reported by the Adjutant General's report to have "died by suicide" did not matter and his widow’s pension application was successful. ${ }^{106}$

While the pension system grew to support large numbers of veterans after the war, some veterans needed more help. Because many veterans, especially those disabled in the war, struggled to support themselves economically Congress also established a system of care for disabled and homeless veterans. The National Home for Disabled Veterans, originally called the National Asylum for Disabled Volunteer Soldiers, was established just before Confederate surrender in 1865 . The system consisted of branches located in different states that served veterans who were disabled and could not support themselves or did not have the support of their families. By the 1870s the National Home had four branches helping thousands of veterans. At the turn of the century the number of branches had doubled and the system had housed nearly 100,000 veterans. The Home was originally open only to soldiers disabled by wartime injuries,

\footnotetext{
${ }^{106}$ Widow application (Mary; soldier, Matthew Young) 21039, certificate 241673 and minor application (Lizzie Young) 367226, certificate 245131. National Archives, Washington, D.C.; Annual Report of the Adjutant-General of the State of New York. For the Year 1904. Registers of the One Hundredth and Fortieth, One Hundred and Fortyfirst, One Hundred and Forty-second, One Hundred and Forty-third, One Hundred and Forty-fourth, One Hundred and Forty-fifth, and One Hundred and Forty-sixth Regiments of Infantry (Albany: Brandow Printing Company, State Legislative Printers, 1905), 687. http://dmna.state.ny.us/historic/reghist/civil/rosters/Infantry/143rd_Infantry_CW_Roster.pdf.
} 
but similar to the pension system, this was later expanded to include soldiers unable to support themselves because of age or age-related illness and disability. ${ }^{107}$

There is a definite emphasis on the physically disabled within the National Home. The act establishing the Home stated eligible veterans were those "disqualified from procuring their own maintenance and support by reasons of wounds received or sickness contracted while in the line of duty." 108 The official seal of the National Home depicts the figure of Columbia holding out a cup to a uniformed Union soldier who had lost his right leg and holds a cane in his right hand as he reaches for the offered drink with the other. Next to Columbia is a stand with a pitcher and at her feet lies a full cornucopia, signs of domesticity and prosperity. Behind the soldier are three stacked muskets and a drum, representing the military, and at his feet is a cannon and sword wreathed in laurels, representing Union victory in the war. Along with the words "The National Home for Disabled Volunteer Soldiers" ringing the outside of the seal, a banner arches over the two figures declaring "The Nation to her Defenders." 109 The majority of veterans entering the Home were those disabled by amputation, battlefield wounds or other disabilities, wartime illness, or those who were homeless and without family support. Patrick Kelly notes that only a small number of insane veterans entered the Home and these were usually transferred quickly to the GHI because the Home's administration did not have the resources to treat them. In addition to the perceptible emphasis on the physically disabled, the Home's administration also worked very hard to separate itself from the other asylums of the period, those for the indigent and the insane. The institution was originally named the National Asylum but that name was changed in 1873 to avoid the stigma of association with shelters for the

\footnotetext{
${ }^{107}$ Patrick J. Kelly, Creating a National Home, 2-5, 56-57, 133-140.

${ }^{108}$ Patrick J. Kelly, Creating a National Home, 128.

${ }^{109}$ Patrick Kelly talks about the seal in his work-See Patrick J. Kelly, Creating a National Home, 129. The description and interpretation of the seal is from my own viewing of the image.
} 
destitute or insane asylums. The designers of the Home system used several ideas from Thomas Kirkbride's plans for insane asylums, but they never acknowledged this or gave him credit to avoid connecting their system for veterans with Kirkbride's asylums for the insane. ${ }^{110}$

The National Home's focus on the physically disabled veteran and their avoidance of any connection to other asylums of the time, largely insane asylums, reflects the physical and moral emphasis of medical and governmental agencies after the war. While medicine advanced in the post-war period, the study of insanity continued its patterns of attributing insanity to moral and physical causes, especially as optimism waned about curability. This was also reflected in how the government distributed aid to veterans after the war. Aid programs such as the National Home and pensions, favored the physically disabled veteran and veterans suffering mental ailments either had to prove a physical disability to get aid or struggled to legitimate their disabilities. Beyond these programs, the transition of the veteran into civilian life was left largely to a northern society that did not experience the war in the same way soldiers had and still expected upright and moral behavior from veterans. In post-war society, veterans used connections to one another through veteran's societies and reunions to manage their wartime experiences in the context of a society that did not quite understand what they had seen and done during the war.

${ }^{110}$ Patrick J. Kelly, Creating a National Home, 6-7, 90-91, 104, 130, 133-140, 231-232. 


\section{Chapter Five:}

\section{"To Sustain with Him the Relation of Comradeship":}

\section{Veteran Coping and Societal Pressures}

"At times he regarded the wounded soldiers in an envious way. He conceived persons with torn bodies to be peculiarly happy. He wished that he, too, had a wound, a red badge of courage." These battlefield musings of Henry Fleming, Stephen Crane's "youth" in the novel Red Badge of Courage reveal the unique importance of a physical wound, a tangible and visible representation that the soldier had seen and participated in battle. While Stephen Crane was not alive during the Civil War he wrote his novel with a sense of realism about the experiences of the common soldier. While historians have analyzed and argued over which unit was represented by the $304^{\text {th }}$ New York Infantry, there is a general opinion that he based some of his writing on the writings of and interviews with veterans. ${ }^{2}$ Within this realistic style, Crane was not afraid to write about the inner struggle of a soldier in combat or the gruesome reality of battlefield death. On the other hand, while Crane was willing to explore the mental ordeal of battle the story is one of manhood, coming to age, and courage. Fleming runs in his first battle and the rest of the story is his musings on how that will affect his reputation with the eventual redemption of standing firm in the next day's fighting, even leading as the regiment's color bearer (a position that denotes courage). Despite only one direct reference within the novel, the idea that a physical wound is equated with bravery is so central to the narrative that it is the title of the work.

\footnotetext{
${ }^{1}$ Stephen Crane, The Red Badge of Courage. Edited by Mary R. Reichardt (San Francisco: Ignatius Press, 2012), 72.

${ }^{2}$ For the debate over which unit is represented in the Red Badge of Courage see Charles J. La Rocca, The Red Badge of Courage: An Historically Annotated Edition (Fleischmanns, NY: Purple Mountain Press, 1995) which argues that the $304^{\text {th }}$ New York Infantry was based on the $124^{\text {th }}$ New York Infantry and that Crane interviewed veterans of this unit while living in Port Jervis, NY, and Perry Lentz, Private Fleming at Chancellorsville: The Red Badge of Courage and the Civil War (Columbia: University of Missouri Press, 2006) which argues that the unit was based on French's Division of the United States Second Corps.
} 
Shortly after the Red Badge of Courage was published for the first time in its full novel form, Crane also wrote a short story entitled "The Veteran" that was published in McClure's in August $1896 .^{3}$ This is the story of a much older Henry Fleming, now a veteran long after the war. The story opens with a peaceful country scene, the exact opposite of the scenes described in the novel. Henry Fleming sits with the next generations of his community, men and boys who were too young to bear witness to the war. He admits running in his first battle, but does so an environment of admiration because his listeners know how he proves his bravery afterwards. Despite this one fault, those listening recognize his courage and manhood because they knew he had risen to an officer's rank, although a non-commissioned one, and that meant he had fought well in the war. The brief story ends in tragedy as Fleming wakes that night to a fire destroying his barn. While the other, younger men panic and fumble to douse the flames, Henry demonstrates the same coolness and bravery expected on the old battlefields as he runs into the blaze numerous times to rescue the horses and cows trapped within the barn. Successful in freeing most of his livestock, at the last minute they remember two colts trapped in one of the back stalls of the barn. In he goes again, determined to save the young horses, but moments later the roof collapses and "a great funnel of smoke swarmed towards the sky, as if the old man's mighty spirit, released from its body — a little bottle—-had swelled like the genie of fable." ${ }^{4}$ The smoke was tinged red from the flames, Crane finishes, "and perhaps the unutterable midnights of the universe will have no power to daunt the color of this soul.",5

In "The Veteran" Crane portrays Henry Fleming as the ideal veteran. Having passed the test of manhood in the Civil War, he is respected within the community because he served well

\footnotetext{
${ }^{3}$ Stephen Crane, Red Badge of Courage, 175-180. "The Veteran" is published together with The Red Badge of Courage in this edition.

${ }^{4}$ Stephen Crane, Red Badge of Courage, 180.

${ }^{5}$ Ibid.
} 
and bravely. In a moment of crisis, Fleming demonstrates that same cool bravery he exhibited during his wartime service, starkly contrasted with the fumbling younger men who had not been tested by battle. Without fear of death, Fleming calmly rescues his livestock and saves the life of another man. Within a few short pages, the old version of Crane's "youth" is shown as the veteran who was successful in building his life after the war. He has built a family, represented by his young grandson who listens at Fleming's knee and asks questions about his war stories and the presence of his "eldest son," denoting that he had more than one child. He is economically successful, represented by the barn filled with at least five horses, several cows, and two colts, and the grandson's comment that a neighbor's colt is not as nice as theirs. He also employs several hired men, one of whom is responsible for the fire after borrowing a horse and "unwashed buggy," from Fleming to go into town, implying that Henry owns more than one carriage. Overall the picture that Crane paints of the veteran Henry Fleming is a man who successfully transitioned back into civilian life, became successful and respected within his community, and retained the ideals of manhood, bravery, and courage past his Civil War service to the end of his life.

In the post-war period, society expected veterans to maintain the patriotic and upstanding behavior they had also demanded during the war. Soldiers entering the war with glorious expectations saw their ideas radically changed with their experiences; however, civilians maintained many of those expectations of glory and manly behavior due to their separation from actual combat. ${ }^{6}$ Like the veteran Henry Fleming in Crane's short story, communities expected veterans to readjust to civilian life and be leaders within society. Union soldiers had preserved the Union and ended slavery, a noble and moral victory, and northern civilian society expected

\footnotetext{
${ }^{6}$ Gerald F. Linderman, Embattled Courage: The Experience of Combat in the American Civil War (New York: The Free Press, 1987), 1.
} 
soldiers to uphold these morals through the rest of their lives. Official treatments in the post-war period remained focused on physical wounds and beyond the programs to provide prosthesis, pensions, and homes to those considered deserving and legitimate, the care of veterans largely fell to themselves and their families. As society either forgot veterans or boxed them into stereotypes that legitimated physical wounds and expected moral behavior, veterans turned to each other for support.

While southern communities and families had been very close to the warfront during the Civil War, most northern civilians remained far removed from the battlefield. As the war ended and the United States entered the post-war period of Reconstruction and reconciliation, northern civilians were ready to move on and forget the war or question what the war achieved in light of the failure of Reconstruction. Not only did the families and communities in the north not understand the experiences of war, Brian Jordan argues, they also brushed off the possibility that their veterans might have trouble adjusting because of their victory and triumph in the war and the celebrations to mark their homecoming. If anything, civilians were worried that returning soldiers would be mentally or physically crippled or bring home immoral habits picked up in the armies. Northern society was concerned that the large numbers of young men returning home from several years spent killing, stealing, swearing, and drinking would continue that behavior in their home communities, but without the discipline of officers to contain them. ${ }^{7}$

With the temperance movement continuing in the north, alcohol was a prevalent concern. Many men had either started drinking or increased the frequency of their alcohol consumption,

\footnotetext{
${ }^{7}$ Brian Matthew Jordan, Marching Home: Union Veterans and Their Unending Civil War (New York: Liveright Publishing Corporation, 2015), 3-7, 33-49, 54-69; Susan-Mary Grant, "Reimagined communities: Union veterans and the reconstruction of American nationalism," Nations and Nationalism 14, 3 (2008): 507-514.
} 
and the difficulties of adjusting to civilian life led many veterans into alcoholism. ${ }^{8}$ Records of the Northwestern Branch of the National Home for Disabled Volunteer Soldiers suggest that alcoholism was a serious issue at the institution. Records from the 1880 s show that at least fourteen percent of cases of disease or injury were connected to alcohol. While considered a health and discipline problem within the home that was combated by denying veterans access to alcohol and dealing with withdrawal by administering small doses of narcotics or depressants, these cases suggest trouble transitioning into civilian life. ${ }^{9}$ This alcohol abuse also shows up in the records of insane asylums, where the use of such stimulants was often interpreted within the moral expectations of the century. When a patient was admitted into Utica State Hospital in 1887 from police custody, he admitted to the heavy use of alcohol and drugs for many years, including using opium to sleep. Just previous to his arrival to the asylum he had been in jail for eighteen months for larceny, where he had been deprived these stimulants, thus when he was released he immediately took advantage of that freedom, used liquor and morphine to excess, and got in trouble again. While the case report concluded that "the injury to the head received in youth [at age 15 he fell from a horse] rendered him more susceptible to the baneful effects of stimulants" the patient placed the beginning of his drug and alcohol use to the time period right before and after his service in the $95^{\text {th }}$ New York Infantry. His stay in the asylum did not remedy his ailments; when the soldier filed for a pension in the 1890 s a physician stated that he was "nervous and excitable, the family with whom he makes his home informs me that [he] is restless

\footnotetext{
${ }^{8}$ For more on opiate addiction as related to the Civil War, see David T. Courtright, "Opiate Addiction as a Consequence of the Civil War," in The Civil War Veteran: A Historical Reader, edited by Larry M. Logue and Michael Barton, 103-115 (New York: New York University Press, 2007): 103-115.

9 James Marten, "Exempt from the Ordinary Rules of Life," in The Civil War Veteran: A Historical Reader, edited by Larry M. Logue and Michael Barton, 116-125 (New York: New York University Press, 2007), 122-123.
} 
and uneasy, sleepless and suspicious, always on the move, and walking about from place to place almost constantly."10

In another case at Dixmont State Hospital, the recorded cause for one soldier's insanity was listed as intemperance, more specifically that he became "intemperate from taking quack medicine + spirits for his depression + got in the habit of taking opium when the cholera was prevalent." ${ }^{11}$ While there are no complete statistics showing exactly how many veterans used drugs and alcohol to manage their physical or psychological ailments, references to both appear frequently in post-war records. However, despite evidence that this was a common coping mechanism, it was not accepted by wider society and was considered immoral or "undeserving" behavior in veterans. These fears caused many veterans to struggle in the post-war period to support their families, because employers were reluctant to hire veterans for concerns that they would be troublesome or unreliable. Jordan argues that civilians very quickly believed their obligation to the soldier finished with the close of the war. Even large organizations such as the Sanitary Commission believed their work completed once soldiers mustered out and became veterans at the end of the war. Civilians were ready to move on from the war and accept reunion and reconciliation, viewing the war still in a romanticized light because they had not experienced the reality of it. ${ }^{12}$

Reflecting this romanticized view, Americans sought to create specific images through which to understand the war and its destructive nature. In literature, the Union amputee was a common image that was used to remind readers of the cause for which the war was fought, claim

\footnotetext{
${ }^{10}$ Pension certificate 805977. National Archives, Washington, D.C.; New York States Archives, New York Office of Mental Health, Utica State Hospital Patient Case Files, 1843-1898 (14231-96), Volume 74, Entry 38.

${ }^{11}$ Pennsylvania State Archives, RG-23 Records of the Department of Public Welfare, Dixmont State Hospital, Patient History Books, 1859-1950 ( $2^{\text {nd }}$ Roll, 1863-1866) (Roll 19) Volume II on Roll 6/1865-8/1866.

${ }^{12}$ Brian Matthew Jordan, Marching Home, 3-7, 33-49, 54-69; Susan-Mary Grant, "Reimagined communities," $507-$ 514.
} 
civil rights for freed slaves, or argue for government support and pensions for veterans.

Incomplete bodies also spoke to the social anxieties of the period, of concerns over the masculinity of wounded men, the ideas of "machine men" with industrial parts (prosthetics), and the imagery of "ruin" after the Civil War. In this literature, much of which was sentimental, the amputees' wounds were symbols of honor and bravery, and the focus was largely on the heroism of the soldier and the virtuous responses of their women to them. Unlike literature after twentieth-century conflicts, the literature of the post-war north was primarily optimistic-with the exception of a few authors such as Ambrose Bierce. Gilded Age northerners used stories of the honorable Union veteran to highlight the willingness of citizens to fight for the cause and offset the negative transformations of the war by highlighting cherished ideals. ${ }^{13}$ Frances Clarke argues that "[ $\mathrm{t}]$ he people who created them [the stories] were not mouthing simplistic platitudes. They were engaged in an effort to take control of wartime carnage, invest it with meaning, and turn it to individual, political, and cultural advantage." 14 In addition to the Union amputee, writers used stories that depicted Union officers' deaths as heroic, described the behavior of white soldiers confronting wounds and sickness, highlighted the effects of volunteers on suffering men, or imagined the beneficial impact of Northern volunteerism on warfare to give the nation's experiences meaning during and after the war. These idealized stories sought to protect societal ideals threatened by the war and cope with the loss and destruction experienced during those years. ${ }^{15}$

\footnotetext{
${ }^{13}$ Jalynn Olsen Padilla, “Army of 'cripples': Northern Civil War Amputees, Disability, and Manhood in Victorian America," Ph.D. Dissertation, University of Delaware, 2007), 167-202; Frances M. Clarke, War Stories: Suffering and Sacrifice in the Civil War North (Chicago: University of Chicago Press, 2011), 1-5; Megan Kate Nelson, Ruin Nation: Destruction and the American Civil War (Athens, GA: The University of Georgia Press, 2012), 1-9, 161. James Marten, Civil War America: Voices from the Homefront (New York: Fordham University Press, 2007), 309318.

${ }^{14}$ Frances M. Clarke, War Stories, 6.

${ }^{15}$ Frances M. Clarke, War Stories, 5-6.
} 
There was an expectation that Union veterans would reintegrate quickly and return to being productive members of society. Henry Bellows, president of the United States Sanitary Commission, advised against the long-term institutionalization of disabled veterans in favor of placing them quickly back into their usual homes and industries. His reasoning was that he feared that the government would use veterans as political capital, further disrupting their lives, or that too much support would make them idle, essentially a class of men exempt from the “ordinary rules of life." 16 An early edition of the Soldier's Friend, published even before the surrender at Appomattox, offered four "rules" for returning soldiers. First, the veteran must "reserve a soldierly bearing" in order to impress employers and convince them that they were not one of those rough and rowdy veterans that civilians feared. The next two suggestions were to "select quickly some fitting employment" and prepare oneself for that employment immediately. Finally, for disabled veterans, "What you have lost in body, try to make up in energy, decision, and mental rigor." 17 This last comment left out the possibility that a veteran's disability might not be of the body, but one that prevented the use of the suggested "mental rigor." Even though Gilded Age Americans understood that disabled veterans could not return back to their original occupations, society offered more sympathy to "deserving" veterans, those who worked hard and tried to help themselves. Because prevailing thought about self-reliance considered men who failed to support themselves as emasculated, becoming dependent on another or relying on charity was seen as shameful and the ultimate failure of manhood. This is one reason American society, even those who had worked with soldiers during the war, did not support large aid programs for veterans. They feared that government charity would led veterans to be idle and

\footnotetext{
${ }^{16}$ James Marten, "Exempt from the Ordinary Rules of Life," 118-119.

${ }^{17}$ James Marten, Sing Not War: The Lives of Union \& Confederate Veterans in Gilded Age America (Chapel Hill: The University of North Carolina Press, 2011), 49.
} 
morally deficient. Americans expected veterans to return to former jobs, learn new skills to change jobs, or manage to find some kind of work to support themselves. ${ }^{18}$

This social expectation is illustrated in "My Red Cap," a short story by Louisa May Alcott that follows the transition of Joe Collins from civilian to soldier to disabled veteran through encounters with the female narrator. Written in three parts, the story encounters Joe before, during, and after his service in the Civil War. The narrator first meets Joe when his regiment is passing through her town on the way to the front and then again, six months later, while the narrator worked as a nurse in the Washington hospitals. Joe's arm had been shot off in battle and the narrator develops a relationship with him as he recovers from his injury. Underlying this progression of the relationship between Joe and the narrator is the portrayal of Joe Collins as the ideal disabled veteran, one who works to overcome his physical injury and maintain his independence through working to financially support himself. In the immediate aftermath of his injury, when the narrator first encounters the wounded soldier, she tries to ease his mind by mentioning the possibility of a prosthetic arm. Joe responds by saying, "I guess it won't do much lumberin', so that trade is done for. I s'pose there's things left-handed fellers can do, and I must learn 'em as soon as possible, since my fightin' days are over." ${ }^{19}$ Even while the injury was fresh and Joe suffered from pain and illness, he was already thinking about how to remain self-sufficient and industrious after he recovered.

Several years after the war, the narrator again meets Joe Collins, now working as a messenger in her town, wearing as part of his uniform the red cap noted in the title of the story. At this point in the story, Joe is poor, without family, and troubled by his wounds and other

\footnotetext{
18 James Marten, Sing Not War, 91-100.

${ }^{19}$ Louisa May Alcott, “My Red Cap," in Kitty's Class Day and Other Proverb Stories (Aukland, New Zealand: The Floating Press, 2011), 320.
} 
ailments. However, he refuses to stop trying to work for his living, and avoids the almshouse. Joe falls ill at the end of the story and cannot keep up his work as a messenger. Instead he ends up boarding with a poor mother and helping mind her children, until the narrator finds him again and encourages him to take up residence in the new Soldiers' Home nearby. Once settled into residence at the Home Joe is portrayed as happy, healthy, and carefree. The old veteran is portrayed as the deserving recipient of this charitable aid. He is not only poor and suffering, without family to care for him, and thus in need of the Home; that is only one part of the equation. He is deserving because of his determination to work and be self-sufficient, even as he falls on harder and harder times. Several times he pointedly refuses to beg or call upon the little family he has left to support him. Instead, he is determined to make his own way, despite his injuries and limitations, and this is what makes him deserving of charitable or government aid. ${ }^{20}$

Victorian society was marked by the expectation that Americans exhibit a personality that exemplified self-control and submission to order. In addition, late-nineteenth century America was a fully capitalist society where a man's status was based on his economic success or failure. Emotional control and refinement were important cultural themes of the mid- and late-nineteenth century. Evidence of morality and willpower were signs of a successful man, while poverty, drunkenness, and instability were marks of failure. Movements such as the temperance movement fought against perceived social ills by trying to increase people's willpower to subdue their impulses. Morality was of such great importance to Victorian America that losing control of one's emotions and willpower could itself be diagnosed as insanity or a loss of masculinity. Men (and women) were expected to behave in certain ways to denote their success and morality in a

\footnotetext{
${ }^{20}$ Louisa May Alcott, "My Red Cap."
} 
society that expected tight control over the emotions. ${ }^{21}$ As historian Stephen Berry expressed "[m]en of the nineteenth century were encouraged to cloak their hearts and stifle their doubts, to so carefully groom their public persona as to become it." ${ }^{" 22}$ Just as participation in the war was a test and expression of manhood for Civil War soldiers, success and morality in the post-war period demonstrated that soldiers-turned-veterans retained that masculinity when reentering the civilian world.

Despite societal pressure to conform to standards of control, self-dependency, and economic success some veterans simply could not fit that mold. Wounded, poor, or otherwise broken soldiers who could not provide for themselves and their families were the exact opposite of the masculinity expected at the time. ${ }^{23}$ Physically disabled veterans, particularly amputees, were highly visible and recognized within society as a symbol of sacrifice and deserving pity. Amputations were a very visible representation of Civil War service and at least 21,753 Union men had a limb amputated during the war. Even though veterans with physical disabilities faced unique challenges finding work and maintaining independence, society still expected them to support themselves and show the ideal willpower, morality, and success as non-veteran men. For example, the left-handed penmanship competition organized by William Oland Bourne, editor and publisher of The Soldier's Friend, for soldiers who had lost their right arms emphasized having a strong will to overcome the obstacles of an amputation. ${ }^{24}$ Frances Clark argues that northern amputees could be proud and satisfied with their changed bodies because the definition

\footnotetext{
${ }^{21}$ Michael Barton, Goodmen: The Character of Civil War Soldiers (University Park: The Pennsylvania State University Press, 1981), 70-75.

${ }^{22}$ Stephen William Berry, All That Makes a Man: Love and Ambition in the Civil War South (Oxford: Oxford University Press, 2003), 11; James Marten, Sing Not War, 24-27.

${ }^{23}$ For more on amputations and questions of masculinity see Brian Craig Miller, Empty Sleeves: Amputation in the Civil War South (Athens: The University of Georgia Press, 2015).

${ }^{24}$ James Marten, Sing Not War, 24-27; Frances Clarke, “'Honorable Scars': Northern Amputees and the Meaning of Civil War Injuries," in Union Soldiers and the Northern Home Front: Wartime Experiences, Postwar Adjustments, edited by Paul A. Cimbala and Randall M. Miller, 361-394 (New York: Fordham University Press, 2002), 368-370.
} 
of manhood did not center around physical attributes. Instead the focus was on the relationship of mind and body, and self-improvement, control of the passions and desires, strong character, and resolution of will were central characteristics of masculinity. ${ }^{25}$ Again, this focus on selfimprovement and mental control discounted those veterans who might be struggling with disabilities of the mind instead of those of the body.

In cases where a physical wound was not readily apparent, there was still an air of suspicion that the case may be a fraud. S. Weir Mitchell, the same doctor working with nerve injuries in soldiers during the Civil War, also wrote several pieces of fiction related to his medical work. One piece, entitled The Autobiography of a Quack, was written from the perspective of a sick patient lying in a hospital retelling the story of his life. The majority of the piece relates the patient's childhood, his education in medicine, and his increasingly dishonest and immoral actions that eventually lead to his position as a "quack" doctor. The American Civil War comes toward the end of the story, and the protagonist, following his dissolute path, enlisted and dodged several times in order to collect multiple bounties while avoiding service. After the first few desertions, he joined a regiment with an officer who was much harsher and more vigilant than he had previously encountered. He found himself bound for the front, unable to desert, so he began to feign epileptic seizures so that he was left in a hospital in Washington while the rest of the regiment went to war. He was careful to study and mirror the symptoms of real epileptics confined in the same hospital and he soon found at least three other men who "like myself, were personally averse to bullets, and who were simulating other forms of disease with more or less success." ${ }^{26}$ One claimed rheumatism, another palsy in his right arm, and the third kept an ulcer open in his leg using antimonial ointment.

\footnotetext{
${ }^{25}$ Frances Clarke, "“Honorable Scars,"” 365.

${ }^{26}$ S. Weir Mitchell, The Autobiography of a Quack and Other Stories (New York: The Century Co., 1905$), 73$.
} 
All four malingerers were able to keep up the ruse until a new surgeon joined the ward and quickly found them all out. The new surgeon caught the rheumatism case by asking him to bend over and declaring that the soldier should receive an immediate discharge; upon hearing the news the soldier straightened up more than he should have been able to and the surgeon sent him back to the field. He examined the case of palsy and quickly sent him back to the front as well. In the case of the ulcered leg, the surgeon had the leg locked in a splint, meaning the soldier was unable to apply the ointment he had been using to keep the sore open; once the ulcer healed, that soldier was also returned to his unit. Watching all of this occur the protagonist took great care only to feign his epileptic fits when that particular surgeon was not around, but there came a day when the surgeon arrived and caught him in the act. Acting sympathetic the surgeon cautioned the ward doctor to restrain the soldier gently and take care that he did not hurt himself, he then instructed the doctor to tickle the sole of the soldier's foot to see if it caused the same head spasms they had observed in another case. Of course, the soldier threw his head back in response, trying to fit the symptoms the doctors were discussing, but that reaction caught him in his lie for the surgeon had made the symptom up to determine whether he was a true case of epilepsy. As the surgeon was about to send the protagonist back to his unit in the field, another officer recognized him and the truth about his bounty dodging was revealed, resulting in his arrest and confinement to Fort Delaware for the remainder of the war. In the year after his release from prison he gradually grew ill and was diagnosed with Addison's disease, which placed him in the hospital and brings the reader back to the beginning of the story where the main character is lying in the hospital. The story ends abruptly with the protagonist's death, the finale of a largely immoral and dissolute life. ${ }^{27}$

\footnotetext{
${ }^{27}$ S. Weir Mitchell, The Autobiography of a Quack.
} 
During the war, S. Weir Mitchell studied and diagnosed cases that did not fit entirely within known, physical diseases. Despite this, he was also very concerned with malingering and the ability of soldiers to use less visible ailments as a way out of service in the war. First, published in 1900, The Autobiography of a Quack demonstrates that even many years after the war, the idea that soldiers and veterans could be feigning illness or attributing ailments to wartime service unjustly. Society could easily identify soldiers who had lost a limb or had another physical scar from the war, but veterans who claimed more vague ailments such as chronic illness, lack of energy, dysentery, hernia, intimate illnesses, or other invisible effects of the war posed a challenge of acceptance to wider society. Veterans who suffered psychological issues and substance abuse were even harder for society to understand and sympathize with. ${ }^{28}$

In addition to the societal expectation that veterans would be marked by easily legitimated physical wounds and act the part of the moral and deserving citizen, Gilded Age America quickly boxed Civil War veterans into a variety of stereotypes: tramps and drunkards, institutionalized amputees, dependent pensioners, or brave men who had fought well but who were now antiquated and irrelevant. In the 1870s and 1880s, the symbolic Union amputee now appeared as the "deserving poor" or symbols of nostalgia. These stereotypes mainly came from outside the veteran community as military service declined as proof of manhood in preference to capitalistic ideas of success that took over starting in the 1870s. Veterans understood themselves to be separated from society, but not in the same way outsiders perceived them to be, and they spend much of the late-nineteenth century fighting to preserve the memory of the war and maintain their masculinity and relevance. ${ }^{29}$

\footnotetext{
${ }^{28}$ James Marten, Sing Not War, 77.

${ }^{29}$ James Marten, Sing Not War, 247-255; Jalynn Olsen Padilla, “Army of “cripples," 167-202.
} 
Just two years after the close of the war the New York Times published an article that stated that "a heroic generation seems to be gathered away from life. It is the universal experience of history that almost before a nation has made ready to do justice to its heroes, the most of them are gone, and it is the minority of survivors or another race of heroes who reap the benefits of the intended bounty." ${ }^{30}$ Of course, with a conflict where thousands of young men had taken up arms, the majority of veterans were not gone after only two years had passed.

Americans who had not been combatants during the Civil War seemed quick to dismiss veterans and instead focus on the Civil War dead. The heart of commemoration and the perceived legacy of the war lay in cemeteries scattered across the nation where those who paid the ultimate sacrifice lay buried. The dead were a comfortable symbol of sacrifice, nationalism, and Union in the post-war period as American society tackled the problems of Reconstruction and commemoration. Veterans were less comfortable because they too had fought for the nation but had not died and faced a dislocation because of the experiences that now separated them from civilian non-combatants. ${ }^{31}$ Whereas the Civil War dead were easily defined as ideal citizensoldiers "raising no awkward questions about how, having made a citizen into a soldier, society might safely reverse the process." ${ }^{32}$

This uneasiness between the veteran and northern society was also evident within veterans' families. As close as veterans remained with their families and communities at home, they were inevitably changed by the experience of war. Distance from home often led to changes in soldiers' behavior, but it also created a psychological distance between themselves and those who did not fight. Recruits and civilians, particularly in the beginning of the war, held very

\footnotetext{
${ }^{30}$ Susan-Mary Grant, "Reimagined communities," 514-515.

${ }^{31}$ Susan-Mary Grant, "Reimagined communities," 499-501.

${ }^{32}$ Susan-Mary Grant, "Reimagined communities," 515.
} 
idealistic expectations of warfare and soldier behavior. As recruits became soldiers and veterans, experiencing campaigning and combat, they realized that the war did not fit their early expectations. However, much of the civilian population continued to hold their idealistic notions of war and held soldiers to high standards of behavior, not fully understanding the environment of war. This created a division between soldiers and civilians based on their different experiences of the war. Some soldiers believed their communities no longer respected the soldier, especially if there were charges that men who remained home were copperheads or avoided serving in the war. Other soldiers felt ignored or neglected by those on the homefront if letters were scarce or visits home were tense. More importantly, there was a psychological gap created once soldiers had experienced war; they struggled to communicate those experiences to friends and family at home that did not experience the same things. ${ }^{33}$ As Earl Hess writes, once recruits became soldiers and veterans they had "crossed over the gulf of experience, leaving behind relatives and friends who could not know what had happened to them." ${ }^{34}$

A major fear of returning veterans was the inability to reconnect to their loved ones, particularly their spouses, because they recognized how the war had changed them.

Compounding this fear were instances where family members did not recognize their returning soldiers, creating a tense homecoming for the veterans. Nancy Hensley did not recognize her husband, William Wallace Hensley, when he returned home earlier than expected and he wrote that "she stared at me like she was scared." ${ }^{35} \mathrm{He}$ reasoned that his changed appearance caused this apparent fright and confusion. John Dulebohn experienced something similar when he

\footnotetext{
${ }^{33}$ Reid Mitchell, The Vacant Chair: The Northern Soldier Leaves Home (New York: Oxford University Press, 1993), 32-35; Earl J. Hess, The Union Soldier in Battle: Enduring the Ordeal of Combat (Lawrence, KS: The University Press of Kansas, 1997), 20; Gerald F. Linderman, Embattled Courage: The Experience of Combat in the American Civil War (New York: The Free Press, 1987), 216-229.

${ }^{34}$ Earl J. Hess, The Union Soldier in Battle, 20.

${ }^{35}$ Brian Matthew Jordan, Marching Home, 51.
} 
returned to his Pennsylvania home and his mother did not recognize him, demanding "Who are you?"36 When Eric Paul returned home after a time as a prisoner of war, he was "so changed in appearance that nobody knew me, not even my mother. She said positively that I was not her Eric, and that broke me all up." ${ }^{37}$ Once soldiers were back in their homes they faced a long adjustment period, which many civilians viewed as a temporary phase that needed to be weathered like a storm before life would return to normal. ${ }^{38}$

Contrary to civilian expectations of homecoming and adjustment, returning soldiers were apprehensive about the end of the war. While most of them longed to return home and had sustained themselves with thoughts of family through the war, many were unsure how to return to civilian life after the trials of the war. Even the waiting period between the end of hostilities and their official muster out was unsettling to many soldiers who longed for the familiarity of army routine and activity. Leaving the army also meant leaving the companions and comrades who were the soldier's primary support system during the war, the men who understood the most the ordeal they had all just passed through. ${ }^{39}$ Sharing the traumatic experiences of war created a special bond among comrades; as Lyman Jackson wrote, "I love those that I have suffered with." 40 Most regiments and companies had been recruited from the same areas at the beginning of their service, but additional recruitment and army consolidation meant that the men leaving the army were not always from the same area. While communities might hold several members of a unit who could support each other in the post-war period, some comrades and close messmates might move or live farther away. When Irving Bronson mustered out he wrote, "We

\footnotetext{
${ }^{36}$ Brian Matthew Jordan, Marching Home, 50.

${ }^{37}$ Ibid.

${ }^{38}$ Brian Matthew Jordan, Marching Home, 52.

${ }^{39}$ Brian Matthew Jordan, Marching Home, 20-25.

${ }^{40}$ Brian Matthew Jordan, Marching Home, 25.
} 
had said goodbye and shaken hands, some of us for the last time. It was like breaking up a family, and about as cheerful as a funeral." ${ }^{\prime 41}$ As soldiers left their units and returned home, some met with triumphant fanfare and others returned home quietly and unnoticed to communities of citizens who were not quite positive how to handle the returning veterans. Even the triumphant Grand Review was full of mixed emotions for soldiers. As Brian Jordan claims, the Grand Review was "the first of many struggles between veterans, who would forever peer over their shoulders and into the past, and civilians, who having missed the distinctive experience of the war were stubbornly unwilling to remember." 42 This sense of isolation made connections with close comrades even more important and the mess more of a soldier's family during the war. These were the men who understood what the soldier had seen, heard, and done during the war. ${ }^{43}$

The separation between veterans and civilians in the post-war period and the need of former soldiers to build a support system to get through the adjustment to civilian life led veterans to turn to the same support system they had used during the war: their comrades. Civilians were quick to move past the war, but veterans marked important anniversaries, published veterans' newspapers, visited battlefields and organized reunions, erected monuments, gathered relics and loaned them to museums, and recorded their wartime recollections in regimental histories and memoirs. Reunions for veterans associations and battle anniversaries usually included civilians and non-war related activities, but the events always highlighted the distinction between veterans and civilians, almost celebrating that divide and recreating the experiences of soldiering and comradery remembered from the war. Visits to battlefields and cemeteries in particular demonstrated the veterans' claims to the fields that civilians did not have

\footnotetext{
${ }^{41}$ Brian Matthew Jordan, Marching Home, 25.

${ }^{42}$ Brian Matthew Jordan, Marching Home, 39.

${ }^{43}$ Gerald F. Linderman, Embattled Courage, 234-236.
} 
and rituals served to bond veterans together in their shared experiences, apart from civilian visitors. Troubled by the lack of support they faced from society and the easiness with which the north moved past the war, veterans felt the need to record their history and remind the public of their sacrifices. Thus, a Civil War soldier's concept of "veteranhood" recognized that their experience of the war differed vastly from that of civilians who could not really understand what it meant to be a veteran, and realized that they needed to band together to share experiences, provide support to each other, and memorialize their dead and their cause. ${ }^{44}$

While the height of reconciliation, reunion, and memorialization came during the $1880 \mathrm{~s}$, veterans were active right away in creating organizations to support one another in the post-war period. Veteran's organizations from the Grand Army of the Republic (GAR) down to brigade and regimental groups provided the comradery needed with the men who understood their shared experience of the war and offered relief services to soldiers who were struggling with disability, pension applications, or employment. ${ }^{45}$ Previous historians have argued that the Grand Army of the Republic served political purposes in the Gilded Age, particularly in terms of Republican power and veterans' benefits. ${ }^{46}$ While that is very true, these organizations served a much more personal and important purpose, that of providing spaces for veterans to cope and deal with their

\footnotetext{
${ }^{44}$ Brian Matthew Jordan, Marching Home, 68-150; Caroline E. Janney, Remembering the Civil War: Reunion and the Limits of Reconciliation (Chapel Hill: The University of North Carolina Press, 2013), 107-108; Stuart McConnell, Glorious Contentment: The Grand Army of the Republic, 1865-1900 (Chapel Hill: The University of North Carolina Press, 1992), 14-15, 97. See also: M. Keith Harris, Across the Bloody Chasm: The Culture of Commemoration Among Civil War Veterans (Baton Rouge: Louisiana State University Press, 2014) and Barbara A. Gannon, The Won Cause: Black and White Comradeship in the Grand Army of the Republic (Chapel Hill: University of North Carolina Press, 2011) for more on the role of veterans in commemoration and shaping the legacy of the Civil War; James Marten, Sing Not War, 261-267.

${ }^{45}$ Brian Matthew Jordan, Marching Home, 68-150; Caroline E. Janney, Remembering the Civil War, 107-108; Stuart McConnell, Glorious Contentment, 14-15, 97.

${ }^{46}$ In Mary R. Dearing's Veterans in Politics: The Story of the G.A.R. (Baton Rouge: Louisiana University Press, 1952) she argues that the GAR was a powerful political group which allowed former soldiers - what she calls a "highly successful pressure group" (vii-viii) - to gain expansive and expensive benefits from the Federal Government. Stuart McConnell's Glorious Contentment takes a similar theme in arguing that the GAR was a voting/political unit that used its influence to promote pensions and other veterans' benefits, as well as nationalism and "correct" history.
} 
wartime experiences. When the Grand Army of the Republic formalized its National Convention in 1869 the first object of the association was to "preserve and strengthen those kind and fraternal feelings which bind together the soldiers, sailors, and marines, who united to suppress the late rebellion." 47 The other two main objectives of the early Grand Army of the Republic were to assist needy comrades with "help and protection" and extend aid to the widows and orphans of fallen comrades, as well as maintain loyalty to the United States and upholding its ideals. ${ }^{48}$ As for politics, its 1869 Rules and Regulations specifically states that "No officer or comrade of the Grand Army of the Republic shall in any manner use this organization for partisan purposes, and no discussion of partisan questions shall be permitted at any meeting of the Grand Army of the Republic, and no nominations for political offices shall be made."49 While the G.A.R. ended up being a political force, particularly after its revival in the 1870s, its first intention was to be an opportunity for veterans to gather and support one another.

This original purpose of the Grand Army of the Republic is affirmed by the writings of Oliver Morris Wilson, an early organizer and officer of the Grand Army of the Republic in Indiana. ${ }^{50}$ Opening his history of the organization and growth of the GAR Wilson writes that after the hardships of their service, it was natural "for such men to possess a feeling of the very closest friendship for those who had shared with the such service, which they knew could only be felt by those who had lived with them through the hours and days and years of a terrible war." ${ }^{\text {" }}$ At the end of the war their comradeship was broken and this loss was felt by soldiers as

\footnotetext{
${ }^{47}$ Rules and Regulations for the Government of the Grand Army of the Republic, as Revised and Adopted in National Convention, Cincinnati, Ohio, May 12 and 13, 1869 (Washington, D.C.: Gibson Brothers, Printers, 1869), $1-2$. history of the Grand Army of the Republic.

${ }^{51}$ Oliver Morris Wilson, The Grand Army of the Republic Under its First Constitution and Ritual (Kansas City, MO: F. Hudson Publishing Co., 1905), 9-10.
} 
they transitioned into their civilian lives. Thus the veteran happily took every opportunity to reconnect with former comrades after the war. "Out of such emotions of comradeship," Wilson wrote, "in the spirit of fraternity, came the civic organizations of soldiers to reunite the fellowship formed in the army, and retain the touch of elbow taken so many times when, even to do so, death was to many the result..."52 Wilson acknowledges how the G.A.R. grew within politics, but claimed that it was not inherently a political organization, rather one that focused on its motto of "fraternity, charity, and loyalty." 53

Over the course of Wilson's history he expressed dissatisfaction with changes within the organization that ultimately affected how veterans related to the Grand Army of the Republic. The GAR became stricter and ritualized at both the local and national levels (although more so at the national level), and this, Wilson claimed, turned veterans away. When the GAR restructured, Wilson stated, membership and participation decreased. "It was hard for the soldier at that day to resist the fellowship of his comrades," Wilson wrote, "If he was not in active co-operation, he was in sympathy with him, and only when other elements of organization, called principles of government, were brought into the Order, did he hesitate and finally withdraw, or step aside from participation...It was organized for the soldier, and in every way it could be wrought for his good and promotion..." ${ }^{54}$ By the end of his history, written then from the perspective of 1901, Wilson lamented that increased rules and rituals had turned members away when all members wanted was fellowship with their former comrades, going as far as to say that the initial goals of "fraternity, charity, and loyalty" had been lost. ${ }^{55}$ In his final statements he reiterates the necessity of comradeship for Civil War veterans, writing that "many prefer to seek their companionship

\footnotetext{
52 Ibid.

${ }^{53}$ Oliver Morris Wilson, The Grand Army of the Republic, 15-25.

${ }^{54}$ Oliver Morris Wilson, The Grand Army of the Republic, 132.

${ }^{55}$ Oliver Morris Wilson, The Grand Army of the Republic, 204-206.
} 
among Veterans, whose life with its war infirmities gives evidence of that proper sympathy felt by every soldier, because he knows what it was, to sustain with him the relation of comradeship." $" 56$

Following similar patterns, prison camp survivors created their own groups beyond their regimental ties because surviving prison was an experience not shared by all veterans who had served in the war. ${ }^{57}$ Organizations such as the Association of Union Ex-Prisoners of War, the National Society of Andersonville Survivors, and the Chicago Association of Ex-Union Prisoners of War connected veterans who had suffered the prisoner experience. ${ }^{58}$ These organizations had similar purposes as other veteran's associations. The first goal of the Ohio Association of Union Ex-Prisoners of War was to hold annual reunions and "thereby renew, keep alive and vigorous the affections, sympathies, and kindred experiences engendered and shared in during imprisonment in rebel prison-pens." 59 The other goals of the Association were to preserve the history and experiences of their times as POWs and hand it down to posterity, to encourage forgiveness towards Confederates and those who treated Union POWs badly, and to give aid to "unfortunate and destitute comrades." ${ }^{60}$ Former POWs separated themselves from the rest of veterans as a particularly victimized population. ${ }^{61}$ In remarks presented to the Ohio Association of Union Ex-Prisoners of War, Governor Patrick stated, "Those who have been in Southern prisons, who have endured all the sufferings and privations, know more of war than the soldier

\footnotetext{
56 Oliver Morris Wilson, The Grand Army of the Republic, 204-205.

${ }^{57}$ Brian Matthew Jordan, Marching Home, 131-150.

${ }^{58}$ James Marten, Sing Not War, 268.

${ }^{59}$ Constitution and By-Laws of the Ohio Association of Union Ex-Prisoners of War, Together with Register of Members And Proceedings at the Reunion held at Dayton, June 14 and 15, 1882. Organized at Columbus, Aug. $11^{\text {th }}$, 1880; Reorganized at Cincinnati, Sept. 15 th 1881 (Columbus, OH: Ohio State Journal Printing Establishment, 1883), 31 .

${ }^{60}$ Ibid.

${ }^{61}$ James Marten, Sing Not War, 268.
} 
who has a mere routine experience."62 Many of the speeches given at this 1882 reunion emphasized the heroic bravery and sacrifice of Union prisoners above and beyond the normal call of duty. They also recognized the importance of reunions and other gatherings for veterans. Vice-President O'Neall of the Ohio Association of Union Ex-Prisoners of War remarked in his address, "Comrades, you know and I know, every comrade here knows, that what we suffered will never, can never be told. For the sake of my country, I thank God that only those who were actual prisoners of war can have the faintest conceptions of what we did endure..." ${ }^{63}$ Besides the speeches, parades, and other lively festivities of the reunion, the afternoon of the first day was filled with "Experience meetings." These gatherings were meant for members to share stories and memories from their time in the war and as POWs. It was a space to relive memories that others outside their circle of experience might not fully understand. ${ }^{64}$

Beyond creating opportunities for veterans to gather and share memories with those who best understood their experiences, veteran's organizations also assisted veterans in securing pensions or other government benefits. Beyond organizations such as the GAR pushing politically for veteran's benefits, they also connected comrades across the country who might testify for one another in pension applications. For example, a note printed in the published proceedings of the 1882 Dayton reunion of the Ohio Association of Union Ex-Prisoners of War asked this request:

Any of the comrades who were in the last squad of 3,000 that left Andersonville and reached our lines at Jacksonville, Florida, the $28^{\text {th }}$ of April, 1865, if you remember the circumstance of a rebel guard cutting a prisoner with a sabre, sometime on the march between Andersonville and Jacksonville, by letting us know of the same, you can be the means of enabling a worthy comrade to get a pension. ${ }^{65}$

\footnotetext{
${ }^{62}$ Constitution and By-Laws of the Ohio Association of Union Ex-Prisoners of War, 6.

${ }^{63}$ Constitution and By-Laws of the Ohio Association of Union Ex-Prisoners of War, 6-7.

${ }^{64}$ Constitution and By-Laws of the Ohio Association of Union Ex-Prisoners of War, 12-16.

${ }^{65}$ Constitution and By-Laws of the Ohio Association of Union Ex-Prisoners of War, 30.
} 
Testimony from comrades who could attest to the timing and causation of a wound during the war was often crucial to the success of a pension application, particularly in cases where the official records were incomplete or the wound was questionable (i.e. in cases of mental wounds or ailments such as rheumatism). Veterans organizations connected comrades who had spread across the United States in efforts to support one another in their attempts to gain government benefits and to manage their memories of the war.

Similar to the wartime period, official forms of recognition and treatment, along with society's understandings of mental illness and expectations for certain behavior, legitimated physical wounds and focused on physical or moral causation of mental injuries. As a result, soldiers suffering from mental trauma or experiencing difficulty transitioning back to their civilian lives had to rely on unofficial treatment and coping options. Just as during the war when comrades provided a crucial support system for traumatized soldiers, in the post-war period former comrades and veteran's organizations performed the same function. These groups provided spaces for soldiers to talk about their wartime experiences to those who understood them and provided assistance for soldiers unable to work or smoothly transition back into society. 


\section{Conclusion:}

\section{Trauma from the Civil War to the Twenty-First Century}

In 1912, a physician at the Government Hospital for the Insane (GHI) wrote a note in the file of Thomas Lynch, a longtime resident of the asylum. The file notes that Lynch was a soldier during the Civil War in Company $\mathrm{H}$ of the $1^{\text {st }}$ DC Volunteers who was initially admitted in May 1863 for a state of acute mania and discharged three months later, only to return the next year in a state of dementia marked by violent outbursts and the failure of his mental powers from which he never recovered. At the time the note was written Thomas Lynch had been a continuous resident of the GHI for almost five decades, and he would die there. Unfortunately, there are no files existent for Lynch prior to 1901, so much of the story of his mental illness is lost and the only picture painted of this patient is an old and irrational man. However, it is noted that Lynch entered the hospital immediately after his discharge from the army and never recovered from his mental illness. ${ }^{1}$

While post-war America expected Civil War veterans to re-enter civilian life and focused on maintaining the self-sufficiently of physically wounded veterans, there were those who faded into memory in the confines of the nation's asylums. Thomas Lynch was not alone in his story of a life and death marked by confinement and mental illness. Many veterans found in asylums after the war were long time residents, or had histories marked with repeated stays in one or several institutions. These men faced a more pessimistic and custodial asylum atmosphere. Gone were the days of optimistism in curability, shattered by the overwhelming numbers of incurable and

\footnotetext{
${ }^{1}$ File \#1328 Thomas Lynch. Records of St. Elizabeth's Hospital. Record Group 418. National Archives, Washington, D.C.
} 
long-term patients. This custodial atmosphere continued until another war, occurring just a few years after Lynch's death, reawakened the debate about mental illness, soldiers, and curability. ${ }^{2}$

A study of mentally affected soldiers and veterans reveals the lack of change brought on by the Civil War in the officially recognized understandings of the brain and its psychological processes. Based on our current knowledge, it is clear that some Civil War soldiers reacted to warfare negatively and suffered some form of mental trauma. As seen in chapter one of this study, soldiers experienced symptoms that can be connected to today's diagnosis of PostTraumatic Stress Disorder, and they struggled to understand these symptoms and experiences or help their comrades suffering from these ailments. During the Civil War both the United States Army and insane asylums did not fully make the connection between the experience of soldiering and the breakdown of men, instead focusing largely on physical or moral causation. The military and medical community recognized the problem presented by broken down soldiers in the context of contemporary ideas about insanity. Military officials recognized when a soldier was not effective in the field, but fears of malingering and the need for manpower led to limited options for treatment or relief. Outside the military, asylums and early psychiatry were heavily influenced by wider American cultural ideas about gender, religion, and proper behavior leading to the physical and moral focus of their treatments. In response, soldiers created their own culture of coping that utilized familiar concepts from their civilian life to manage their wartime experiences. Operating within the same American culture that limited their official treatment options, soldiers tried to utilize some of those familiar cultural ideas to maintain their mental health during the war. When those failed, soldiers sometimes operated outside the norm of cultural standards to relieve the stress of soldiering.

\footnotetext{
2 J. M. Binneveld, From Shell Shock to Combat Stress: A Comparative History of Military Psychiatry (Amsterdam: Amsterdam University Press, 1997), 66-69.
} 
Similarly, in the post-war period society and the United States government continued to hold these ideas of mental illness and the effects of soldiering on the men who fought in the war. While the Civil War did bring a lot of change to America, many of the cultural norms remained through the war into the post-war period. There was still a large focus on physical and recognizable illnesses and disabilities, but no full recognition, medically or officially, of the invisible mental wounds suffered by many veterans. In asylums, soldiers' homes, the pension system, and literature about the war, there was a large focus on the visibly disabled veteran and a belief that veterans must operate as the pinnacle of proper behavior and continue to prove themselves as the "saviors" of the nation. Here too, former soldiers had to create their own methods of coping with their transition to veteranhood and their past experience of war that largely relied on other veterans who had shared in the same struggles.

While the period after the Civil War saw an increase in medical discourse about trauma, there was still a general focus on physical causation. For example, discussion of "railway spine"- mental symptoms thought to be a result of concussion to the spinal cord caused by railroad and industrial accidents — starting in the mid-nineteenth century raised questions of physical versus mental disorders. By the turn of the century there was more acceptance of nervous disorders, but there was still the overarching understanding that these were caused by physical trauma to the brain or nervous system. ${ }^{3}$ This physical causation was transferred to the beginning of World War I when the disorder "Shell Shock" was first diagnosed. As patients

\footnotetext{
${ }^{3}$ Paul Lerner and Mark S. Micale, “Trauma, Psychiatry, and History: A Conceptual and Historiographical Introduction," in Traumatic Pasts: History, Psychiatry, and Trauma in the Modern Age, 1870-1930, edited by Mark S. Micale and Paul Lerner (Cambridge: Cambridge University Press, 2001), 11; Ralph Harrington, "The Railway Accident: Trains, Trauma, and Technological Crisis in Nineteenth-Century Britain," in Traumatic Pasts: History, Psychiatry, and Trauma in the Modern Age, 1870-1930, edited by Mark S. Micale and Paul Lerner (Cambridge: Cambridge University Press, 2001), 32-55; Eric Caplan, "Trains and Trauma in the American Gilded Age," in Traumatic Pasts: History, Psychiatry, and Trauma in the Modern Age, 1870-1930, edited by Mark S. Micale and Paul Lerner (Cambridge: Cambridge University Press, 2001), 57-77.
} 
began coming into hospitals with symptoms ranging from muteness, exhaustion, and memory loss to paralysis and uncontrolled tremors as early as 1914 the belief was that these soldiers' brains had been physically damaged by the concussive force of artillery shells. When Charles S. Myers, a doctor in the Royal Army Medical Corps, first published the term "shell shock" he was approaching the disorder through purely somatic terms. Despite the realization that "shell shock" could not be purely physical, since some patients exhibiting such symptoms had not been close to an artillery explosion, the focus remained on the physical. The most common treatments for "shell shock" during World War I were "rest cure" or electric shock therapy to either place soldiers in a therapeutic environment similar to the "moral treatment" of the past or treat the physical symptoms of the condition. The majority of traumatized soldiers during the Great War received treatment in a general hospital with no specialty in "shell shock" or received a month's rest in the country in an effort to bolster their morale for a return to the front lines. ${ }^{4}$

World War I was the first conflict where the debate between physical and mental causation of insanity or "shell shock" symptoms gained real legitimacy in both the medical field and wider community. However, there was a continuation of familiar arguments about hereditary and moral weakness that existed from the Civil War. First there was the argument that it was from physical causation, then the claims that "shell shock" stemmed from either hereditary weakness or fraud to get out of military service. Some did argue that "shell shock" had a psychogenic origin and the United States actually saw psychiatry swing back towards optimism about curability in the years right before their entrance into the war; however, the policies of the American Expeditionary Force mainly revolved around seeing psychological casualties as a

\footnotetext{
${ }^{4}$ Peter Leese, “'Why Are They Not Cured?’ British Shellshock Treatment During the Great War,” in Traumatic Pasts: History, Psychiatry, and Trauma in the Modern Age, 1870-1930, edited by Mark S. Micale and Paul Lerner (Cambridge: Cambridge University Press, 2001), 206-220; J. M. Binneveld, From Shell Shock to Combat Stress, 8490.
} 
problem of military manpower and government finances. So while American psychiatrists recommended that traumatized soldiers be treated quickly and close to the front to ensure their recovery, there was also a large focus on screening recruits for mental deficiencies that would predispose them for breakdown in combat. Consequently, despite hundreds of cases of shell shock resulting from combat, the American military and medical policy continued to argue that mental breakdown was caused by hereditary predisposition that could be identified through screening and that patients could be cured by "re-educating" them in proper masculine behavior. ${ }^{5}$

Just as in the Civil War and post-war period, treatment of "shell shock" was heavily influenced by the gender expectations of the army and wider society. On one hand, there was a wider understanding that the war could cause mental collapse and that any soldier was susceptible due to the environment of war; however, society still held Victorian standards of proper behavior and stressed personal responsibility for both physical and mental health. There was an emphasis on self-control that translated to a failure of mental health as the failure of a man's will power and patients were considered responsible for their own recovery through selfcontrol. Similar to the Civil War, cases of "shell shock" were connected to malingering or the failure of a soldier's masculinity. ${ }^{6}$

Despite several close similarities between the Civil War and World War I, the imagery of the "shell shocked soldier" became very important in legitimizing the concept of a psychological casualty of war. At the time, the "shell shocked soldier" became a metaphor for the problems of an increasingly industrialized world, but the discussion of these wartime casualties in society

\footnotetext{
${ }^{5}$ Annessa C. Stagner, "Defining the Soldier's Wounds: U. S. Shell Shock in International Perspective,” (Ph. D. Dissertation, University of California, Irvine, 2014), 13-90; J. M. Binneveld, From Shell Shock to Combat Stress, 86-90.

${ }^{6}$ Fiona Reid, Broken Men: Shell Shock, Treatment, and Recovery in Britain, 1914-1930 (London: Continuum, 2010), 9-25.
} 
increased the recognition of mental breakdown during war. ${ }^{7}$ Both the military and medical field held similar concerns about manpower when entering World War II, but there was more research done in this second war because armies wanted to study causation to prevent large numbers of psychiatric casualties. Patients during World War II were often labeled as suffering from "combat exhaustion" or "battle exhaustion" because exhaustion is not considered a permanent condition. Soldiers could seek treatment for "exhaustion" without the stigma of insanity and carry the expectation that they would return to their units recovered. ${ }^{8}$

It was not until Vietnam and the diagnosis of Post-Traumatic Stress Disorder in 1980 by the American Psychiatric Association (APA) that intense research on the effects of warfare on soldiers was studied. Vietnam created a new diagnostic category, that of "combat stress." This new categorization recognized the biochemical reactions of the human body under conditions of stress as well as the individual responses humans have to stressful situations (i.e., different people experience the same events differently). Vietnam proved the first opportunity after these biochemical discoveries to test new theories on soldiers. Experiments on American soldiers found that chemically there were no big changes in soldiers experiencing combat, but that soldiers continually created defense mechanisms to cope with the stress while it was occurring. As a result of these studies, the APA recognized the official diagnosis of PTSD in the aftermath of that conflict. ${ }^{9}$

With the recent conflicts in the Middle East, Post-Traumatic Stress Disorder and mental trauma in soldiers and veterans have received increased attention. Current theories about wartime trauma reflect a combination of these cyclical theories evident in past military conflicts. Modern

\footnotetext{
${ }^{7}$ Fiona Reid, Broken Men, 1, 8-9.

${ }^{8}$ J. M. Binneveld, From Shell Shock to Combat Stress, 93-97.

${ }^{9}$ J. M. Binneveld, From Shell Shock to Combat Stress, 97-99; Paul Lerner and Mark S. Micale, "Trauma, Psychiatry, and History," 1.
} 
psychologists consider all soldiers capable of becoming psychological casualties and argue that all combatants face the possibility that their "fortitude" or their personal psychological reserves will run dry. As Lieutenant Colonel Dave Grossman writes in On Killing, "Faced with the soldier's encounters with horror, guilt, fear, exhaustion, and hate, each man draws steadily from his own private reservoir of inner strength and fortitude until finally the well runs dry." 10 Once that "well of fortitude" runs dry, the soldier might become a psychological casualty. Psychologists and historians have used various images and analogies to explain this process; for example, a well that if drawn from enough runs dry, a bank account that a soldier can deposit into and withdraw from until there are no funds left, or a lake of "Physical and Psychological Exhaustion" that rain from the "Cloud of Pressures" goes into and makes the level of the lake rise and fall. ${ }^{11}$

A main tenant of modern theory on PTSD is the individuality of responses to combat stress. Psychiatrists argue that individuals face each situation with different backgrounds that determine whether they develop symptoms of trauma and to what degree. This explains why people exposed to the same traumatic event react differently, and why only one out of four people exposed to traumatic events develop PTSD. ${ }^{12}$ Individuality also affects a person's coping response and how they manage their experiences. According to Israeli military psychologist, Ben Shalit, coping is a continuous process in reaction to situations that are threatening, frustrating,

\footnotetext{
${ }^{10}$ Dave Grossman, Lt. Col., On Killing: The Psychological Cost of Learning to Kill in War and Society (New York: Back Bay Books, 2009), 82.

${ }^{11}$ Richard Holmes, Acts of War: The Behavior of Men in Battle (New York: The Free Press, 1985), 223; Elmar Dinter, Hero or Coward: Pressures Facing the Soldier in Battle (Totowa, NJ: Frank Cass and Company Limited, 1985), 60-61; Dave Grossman, Lt. Col., On Killing, 82-85.

12 Daryl S. Paulson, Haunted by Combat: Understanding PTSD in War Veterans Including Women, Reservists, and Those Coming Back from Iraq (Westport, CT: Praeger Security International, 2007), 10-14; Mooli Lahad and Miki Daron, Protocol for Treatment of Post Traumatic Stress Disorder. SEE FAR CBT Model: Beyond Cognitive Behavior Therapy, Part of the NATO Science for Peace and Security Project ASI 983481 (Amsterdam: IOS Press, 2010), vii, 7; Stanley Krippner, Post-Traumatic Stress Disorder (Santa Barbara, CA: Greenwood, 2012), 2-5.
} 
challenging, or gratifying and each coping process is unique to the person and situation. Key to Shalit's theory of coping is that to cope with a situation the person must first perceive it, and this leads to very individualized coping. ${ }^{13}$ Each person, in this case each soldier, will see a situation differently based on their position in the field, their perception of the events occurring around them, and their personal past experiences. Every element of battle, as Ben Shalit argues "is likely to be differently perceived, and thus differently interpreted and differently reacted to by each individual who is exposed to the conditions." 14 Nothing can be in purely objective terms because "Truth is in the eye of the beholder-as are falsehoods...It is therefore critical to have a picture of how each individual perceived a situation, because each person will have a problem in coping with those aspects that are most critical to him." 15 Shalit found that each soldier had different things they would consider as their primary fear, and this primary fear could change depending on the situation. That particular fear was a soldier's "weak link" and they could not cope with the entire situation if they could not cope with that specific fear. Coping could not occur unless the soldier perceived it (and could understand it) and could not be successful until the person perceived that the problem had gone away. ${ }^{16}$

In modern conflicts in the Middle East, we see the debates about physical causation versus psychological causation in the separation of Traumatic Brain Injury from Post-Traumatic Stress Disorder. ${ }^{17}$ The recognition of a physical brain injury due to explosives and head injuries and the separation of that diagnosis from traumatic psychological injuries stems from the debates about physical and mental wounds seen in conflicts back at least to the Civil War. We also

\footnotetext{
${ }^{13}$ Ben Shalit, The Psychology of Conflict and Combat (New York: Praeger, 1988), 15-19.

${ }^{14}$ Ben Shalit, The Psychology of Conflict and Combat, 10.

15 Ibid.

${ }^{16}$ Ben Shalit, The Psychology of Conflict and Combat, 10-15.

${ }^{17}$ Brenda K. Wiederhold, Coping with Blast-Related Traumatic Brain Injury in Returning Troops. [Wounds of War III: Coping with Blast-Related Traumatic Brain Injury in Returning Troops; NATO Sponsored Science for Peace and Security Programme Initiative, February 2011] (Amsterdam: IOS Press, 2011).
} 
continue to see debates over the role of heredity and predisposition to trauma. For the most part this focus on predisposition centers on peoples' diverse backgrounds, religious and cultural beliefs, and previous experiences, although some studies are using new technologies to discover what role genetics might have. Predisposing factors also include previous trauma-including domestic violence, unstable homes as children, bullying, and sexual, emotional, or physical assault in addition to previous traumatic events - or whether the person was in a particularly stressful period of their lives - for example, grieving a loved one. The question remains why when faced with the same trauma some people develop PTSD and others do not, and much of the current theory revolves around finding causational environmental or possible biological factors. ${ }^{18}$ The debates over mental trauma in soldiers is cyclical in nature in the sense that physical causation, hereditary, moral weakness, predisposition, and the effects on military manpower have occurred in each military conflict over the last century and a half. Within the military, the focus remains on maintaining the military manpower needed to successfully fight and win the conflict. Current efforts focus on the "total fitness" of soldiers, training soldiers to be both physically and mentally strong and fit to handle the conflicts of war. In a program such as the "Battlemind Training System" the emphasis is on providing support for soldiers before, during,

\footnotetext{
${ }^{18}$ Peter Pregelj and Alia Videtic, "Possible Involvement of Epigenetic Mechanisms in the Neurobiology of PTSD" in Coping with Posttraumatic Stress Disorder in Returning Troops, edited by Brenda K. Wiederhold. ["Wounds of War II-Posttraumatic Stress Disorder in Peacekeeping and Combat Troops" NATO Sponsored Science for Peace and Security Programme Initiative, October 2009] (Amsterdam: IOS Press, 2010), 3-12; Vsevolod A. Rozanov, "Genes-Environment Interaction and Development of PTSD" in Coping with Posttraumatic Stress Disorder in Returning Troops, edited by Brenda K. Wiederhold. ["Wounds of War II-Posttraumatic Stress Disorder in Peacekeeping and Combat Troops" NATO Sponsored Science for Peace and Security Programme Initiative, October 2009] (Amsterdam: IOS Press, 2010), 13-19; Dragica Kozarić-Kovačić, et al., "Proteomics and Posttraumatic Stress Disorder (PTSD)," in Coping with Posttraumatic Stress Disorder in Returning Troops, edited by Brenda K. Wiederhold. ["Wounds of War II-Posttraumatic Stress Disorder in Peacekeeping and Combat Troops" NATO Sponsored Science for Peace and Security Programme Initiative, October 2009] (Amsterdam: IOS Press, 2010), 57 66; Stanley Krippner, Post-Traumatic Stress Disorder, 2-3; Daryl S. Paulson, Haunted by Combat, 10-14; Mooli Lahad and Miki Doron, Protocol for Treatment of Post Traumatic Stress Disorder, vii, 7; George Rosen, Madness in Society: Chapters in the Historical Sociology of Mental Illness (Chicago: The University of Chicago Press, 1968), 172.
} 
and after their deployment and reducing the stigma of PTSD to encourage soldiers to seek care; however, the goal of that particular program was also described as the "process of developing a Soldier's inner strength to face fear and adversity with courage" with a focus on "selfconfidence" and "mental toughness." ${ }^{\text {"19 }}$ Even with the current recognition of PTSD and the traumatizing effects of experiencing combat, there remains a focus on maintaining a soldier's personal fortitude and mental strength to prevent their breakdown.

While theories on trauma seem cyclical, with many of the same questions appearing from one conflict to another, the main difference is the modern acknowledgement that war traumatizes soldiers. Understanding the similarities and differences between the psychological theories prevalent in the wars of the last century creates a framework to look back further to earlier conflicts. There are connections to be made between the experiences of soldiers, how society interprets broken down men, how the medical field creates theories about trauma, and how the military deals with issues of manpower and discipline that reveal again that trauma is not a postVietnam condition. Extending the study of trauma past the twentieth century to the Civil War illuminates similarities in the diagnosis and treatment of soldiers during wartime, but also allows for the examination of developing theories on mental illness from the very beginning of formalized psychiatry. By examining the medical treatment of insane or mentally afflicted soldiers it shows how nineteenth century physicians and military officers diagnosed and treated mental trauma during the war, and reveals that this line of medical knowledge saw no real

\footnotetext{
${ }^{19}$ Todd M. Yosick, et al., "The Emergence of Total Fitness in the United States Department of Defense: A Necessary Focus for Sustaining the Human System in the New Era of Full Spectrum Operations" in Coping with Posttraumatic Stress Disorder in Returning Troops, edited by Brenda K. Wiederhold. ["Wounds of War IIPosttraumatic Stress Disorder in Peacekeeping and Combat Troops" NATO Sponsored Science for Peace and Security Programme Initiative, October 2009] (Amsterdam: IOS Press, 2010), 237-246; Todd M. Yosick, Major, "Prevention of Suicides in the United States Army," in Lowering Suicide Risk in Returning Troops, edited by Brenda K. Wiederhold. ["Wounds of War-Lowering Suicide Risk in Returning Troops" NATO Sponsored Science for Peace and Security Programme Initiative, October 2007] (Amsterdam: IOS Press, 2008), 98-101.
} 
revolution in contrast to medicine as a whole which saw rapid change after the Civil War. This change would come much later, after several other wars created the need for more scrutiny on the subject.

Analyzing the experience of mentally traumatized Civil War soldiers allows for a fuller picture of the wartime experience of these men, as well as the society in which they operated. The broader picture of the war and post-war periods - including military campaigns, army structure and policies, national politics, post-war reunions, and veterans' organizations_-is already well-established in the scholarship on the nineteenth century. Current research on the struggles of individual soldiers in the context of the war and post-war periods allows for a fuller analysis of the experience of war. Examining how soldiers reacted to the experience of camp and battle and how they managed and coped on a personal level reveals an undercurrent in the creation of the soldiers' culture and reveals gaps in the official recognition of the mental strain of warfare. Finally, extending this study of trauma, treatment, and coping into the post-war period gives new meaning to the already studied topics of literature, pensions, reunions, and veterans' organizations. Official means of recognition and support, such as pensions, did not acknowledge mental trauma apart from a physical cause, supporting the idea that medical and social understandings of mental trauma did not change drastically over the course of the war. And, seen in the context of coping, reunions and veterans' organizations are no longer only political machines or agents of reconciliation, but necessary support systems to ensure the survival of their participants.

This analysis shows as much about mid- to late-nineteenth century American culture as it does about the military and medical profession. It was largely the culture of nineteenth-century America that prevented breakthroughs in recognizing mental trauma and developing treatment 
options for Civil War soldiers affected mentally by the war. Standards of masculinity, selfcontrol, bravery, and social behavior did not allow for negative expressions of stress induced by warfare and battle. Combining an analysis of nineteenth century culture with soldiers’ expressions of coping and reactions to battle reveals how soldiers viewed their own experiences. This research serves as a departure point for future scholarship that offers fuller exploration of the society, military culture, and medical knowledge surrounding soldiers in all wars. Currently, many of the studies being produced by historians separate North and South, looking only at Union or Confederate soldiers. A comparative study that looks at the similarity or differences between the coping and medical experience related to mental health within the armies will allow for analysis, not only of the medical resources of both combatants, but the culture of both sections of the country. There is a suggestion that the culture of the North and the South was different as the United States entered the Civil War; a study of the cultures used by Union and Confederate soldiers in order to manage their wartime experiences will reveal how much separation there truly was. In addition, using the personal and mental experience of the individual as a point of analysis can be used to reexamine military campaigns already studied in a traditional military sense. By combining knowledge of psychology and the brain with a study of military tactics, historians can analyze decision making, coping, and effective fire on the field of battle and can better explain how and why battles flowed in the way they did, how effective various weapons were, why certain tactics were used, and why officers issued the commands they did.

On a broader scale, the studies of how medicine, military culture and training, psychology, and culture changed over time benefits from looking at the Civil War. Many studies of mental trauma or military psychology are restricted to the twentieth- and twenty-first centuries 
because of the more concrete definitions of "shell shock" and PTSD that emerge then. However, since psychologists describe mental stress as an ageless problem, that study can be extended backwards in time to see how different societies in different ages viewed and treated those incapacitated by war. Again, that is not to say that historians should look backwards and label historical cases as PTSD or "combat stress"; however, looking into conflicts waged in the absence of those definitions can reveal the culture, society, and medical practices of those times. In addition, the development of the modern military, in terms of tactics, training, and medical procedure, can be viewed in the light of attempting to combat the psychological nature of war. On one hand humans continually develop more intimidating weapons while also training soldiers to withstand the hardships of war. As introduced in the first chapter of this dissertation, "[a]t its core, war is a battle of minds." ${ }^{20}$ If warfare is primarily psychological, then the study of a soldier's mind needs to be central to it.

One of the largest challenges of this research is access to the medical records of nineteenth-century insane asylums and hospitals. As noted in the introduction, access is severely limited to many of these collections and they fall under HIPAA regulations that require confidentiality. In the most extreme case, one archive required a complete IRB review, with yearly additional reviews, and I must delete all identifying information from my notes at the conclusion of this project, meaning I will not be able to use some of this information again. In moving this type of research forward, I would suggest an effort on the part of historians to engage with the medical community in order to create standards that would allow researchers better access to records of a reasonable age, particularly in cases such as this when the subjects have been deceased for over a century. In a similar way that oral histories within the public

\footnotetext{
${ }^{20}$ Elmar Dinter, Hero or Coward, 9.
} 
history field have been excluded from requiring an IRB review, it would be helpful to have policies that opened more of these historical medical documents up to researchers.

The implications and opportunities presented in this research are vast and offer new roads into the experiences of Civil War soldiers and the questions about the human mind in warfare that still elude exact definition. Yet, it is important to remember that beyond the theories about mental illness, the medical treatments available, and the military policies governing these soldiers, these were men facing the hardest trial of their lives. Whether physical, mental, or emotional, Civil War soldiers carried the weight of their experiences with them for the rest of their lives. Behind every pension application for insanity, every asylum record, every letter to the GHI asking about a husband or father is a man and a family forever affected by the war. Their story is as much an experience of the Civil War as the veterans able to readjust back into civilian society and can shed light on the human experience of war and the nineteenth century. 


\section{$\underline{\text { Bibliography }}$}

\section{Archives:}

Army Heritage and Education Center, Carlisle, PA.

Civil War Miscellaneous Collection.

Civil War Times Illustrated Collection.

The Harrisburg Civil War Round Table Collection.

Henry Van Aerum Papers.

Newel Burch Diary.

Falk Library, University of Pittsburg Health Sciences Library, Pittsburg, PA.

Insane Hospital Reports, 1857-1882, Collection MS 9

Fredericksburg \& Spotsylvania National Military Park, Fredericksburg, VA.

Collection of John Hennessey, Chief of Interpretation

Maine and New Hampshire Manuscripts

Massachusetts Manuscripts

New Jersey Manuscripts

New York Manuscripts

Ohio Manuscripts

Kentucky Department for Libraries and Archives, Frankfort, KY.

Records of Eastern State Hospital: Register

Records of Eastern State Hospital: Patient Commitment Records (Accession No. A2001195)

National Archives, College Park, MD.

Reports of the Government Hospital of the Insane, 1855-1874. Office of the Department of the Interior. Record Group 48.

National Archives, Washington, D. C.

Civil War Pension Files

Records of St. Elizabeth's Hospital; Record Group 418.

New Jersey State Archives, Trenton, NJ.

Department of Human Services. Trenton Psychiatric Services. Annual Reports, 18481973.

New Jersey Home for Disabled Soldiers. Case Files, 1866-1920s. 
New York State Archives, Albany, NY.

New York Lunatic Asylum. Certificates of Insanity, 1884-1886. (B1486)

Utica State Hospital. Patient Indexes, 1849-1903. (B1485-96)

Utica State Hospital Patient Case Files, 1843-1898. (14231-96)

Willard Psychiatric Center, Historical Background and Research Files, 1869-1987

(B1440-96).

Willard Psychiatric Center. Admission and Discharge Registers, 1869-1995 (B1456)

Willard State Hospital. Patient Indexes, 1869-1962. (B1459-96)

Willard State Hospital Case Files, 1869-1938 (14231-95)

Ohio Historical Society, Columbus, OH.

The Allen Family Collection, Mss 1452 AV

Athens State Hospital, Case Book of Male and Female Patients, 1874 (Series 141)

Cleveland State Hospital, Admission Books, 1855-1973 (call\#: State Archives Series

314)

Cleveland State Hospital, Register of Patients, 1855-1906 (call\#: Sate Archives Series 348)

Columbus State Hospital, Admission Books, 1838-1868 (call \#: State Archives Series 896)

Dayton State Hospital, Register of Male and Female Patients, 1855-1902 (call \#: State Archives Series 153)

Hiram Brown Collection, MSS 1489 AV

James M. Merryman Civil War Diary, VFM 5886

Longview State Hospital, Case History of Male and Female Patients, 1863-1918 (call \#: State Archives Series 541)

William H. Kemper Papers, MSS 836

Pennsylvania State Archives, Harrisburg, PA.

Records of the Department of Public Welfare, Dixmont State Hospital, Patient History Books, 1859-1950.

Records of the Department of Public Welfare, Harrisburg State Hospital, Annual and Biennial Reports, 1851-1923, 1926-1928, 1934-1936, 1946-1958, 1969-1

Records of the Department of Public Welfare, Harrisburg State Hospital Admission Registers, 1851-1969.

Harrisburg State Hospital, Medical Case Book, 1851-1867.

Harrisburg State Hospital, Medical Case Book of the Male Department, 1881-1892.

Harrisburg State Hospital, Medical Case Book of the Male Department, 1883-1892.

Harrisburg State Hospital, Medical Case Book of the Male Department, 1885-1892.

\section{Online Archive: SoldierStudies.org.}

Diary, Charles Richard Allen, $2^{\text {nd }}$ Illinois Cavalry

Letters, Thomas J. Bartholomew, $40^{\text {th }}$ Indiana Infantry

Letters, Edward N. Boots, $101^{\text {st }}$ Pennsylvania Infantry

Letters, C. C. Bowen, $6^{\text {th }}$ Ohio Infantry

Letters, John Briggs, $8^{\text {th }}$ Ohio Infantry 
Letters, William H. Collins, $2^{\text {nd }}$ Wisconsin Infantry

Diary, Alexander G. Downing, $11^{\text {th }}$ Iowa Infantry

Letters, Absolom A. Harrison, $4^{\text {th }}$ Kentucky Cavalry

Letters, Robert B. Jefferds, $3^{\text {rd }}$ Michigan Infantry

Letters, William P. Lyon, $8^{\text {th }}$ Wisconsin Infantry

Letters, John McConihe, $169^{\text {th }}$ New York Command

Letters, Edward R. Miles, $100^{\text {th }}$ Pennsylvania Infantry

Letters, O. W. Norton, $83^{\text {rd }}$ Pennsylvania Infantry

Letters, Jacob N. Patterson, $2^{\text {nd }}$ New Hampshire Infantry

Letters, John G. Perry, 20 ${ }^{\text {th }}$ Massachusetts Medical

Letters, Charles E. Persons, $24^{\text {th }}$ New York Infantry

Letters, Chauncey H. Persons, $24^{\text {th }}$ New York Infantry

Letters, Charles S. Ramsay, $44^{\text {th }}$ Ohio Infantry

Letters, Charles A. Stevens, $11^{\text {th }}$ Wisconsin Infantry

Letters, John P. Wilson, $100^{\text {th }}$ Pennsylvania Infantry

Letters, Alfred C. Woods, $62^{\text {nd }}$ New York Infantry

\section{Published Primary Sources:}

Acken, J. Gregory. Inside the Army of the Potomac: The Civil War Experience of Captain Francis Adams Donaldson. Mechanicsburg, PA: Stackpole Books, 1998.

"Affecting Case of Insanity — a Soldier Crazed by the Loss of His Wife, Two Children, and Sister," Wisconsin Patriot, February 15, 1862. America's Historical Newspapers.

Alcott, Louisa May. Kitty's Class Day and Other Proverb Stories. Aukland, New Zealand: The Floating Press, 2011.

Annual Report of the Adjutant-General of the State of New York. dmna.ny.gov/historic/mil-hist.htm.

Bartholow, Roberts. A Manual of Instructions for Enlisting and Discharging Soldiers; With Special Reference to the Medical Examination of Recruits and the Detection of Disqualifying and Feigned Diseases. [Reprinted with a Biographical Introduction by Ira M. Rutkow, M. D., Dr. P. H.] San Francisco: Norman Publishing, 1991.

Beath, Robert B. The Grand Army of the Republic. New York: Bryan, Taylor \& Co., 1889.

Brewster, Charles H. When This Cruel War Is Over: The Civil War Letters of Charles Harvey Brewster. Edited by David W. Blight. Amherst: The University of Massachusetts Press, 1992. 
Butler, Benjamin Franklin. "Letter from Benjamin Franklin Butler to Edwin McMasters Stanton, October 25, 1862." In Private and Official Correspondence of Gen. Benjamin F. Butler During the Period of the Civil War, vol 2, 407. Springfield, MA: Plimpton Press, 1917. American Civil War: Letters and Diaries, accessed 28 January, 2014 (Butler: L1986431).

Calhoun, J. Theodore. "Nostalgia: As a Disease of Field Service.” Medical and Surgical Reporter (1858-1898), February 27, 1864 11, 9. American Periodicals, 130.

Churchill, James O. "Wounded a Fort Donelson." In War Papers and Personal Reminiscences, 1861-1865, Read before the Commandery of the State of Missouri, Military Order of the Loyal Legion of the United States, Volume I, 146-168. St. Louis: Becktold \& Co., 1892.

Constitution and By-Laws of the Ohio Association of Union Ex-Prisoners of War, Together with Register of Members and Proceedings at the Reunion held at Dayton, June 14 and 15, 1882. Organized at Columbus, Aug. 11 th, 1880 ; Reorganized at Cincinnati, Sept. 15 ${ }^{\text {th }}$, 1881. Columbus, OH: Ohio State Journal Printing Establishment, 1883.

Crane, Stephen. The Red Badge of Courage. Edited by Mary R. Reichardt. San Francisco: Ignatius Press, 2012.

Cunningham, Michael R. "Follow me to victory or death": The diaries and letter of Captain Henry Martin Kellogg, 33 ${ }^{\text {rd }}$ Illinois Volunteer Infantry. 1993.

“Domestic Intelligence: News Items.” Harper's Weekly, April 7, 1866, 222. HarpWeek, Accessed February 4, 2011.

Elliott, Isaac H. History of the Thirty-Third Regiment Illinois Veteran Volunteer Infantry in the Civil War, 22 ${ }^{\text {nd }}$ August, 1861, to $7^{\text {th }}$ December, 1865 By General Isaac H. Elliott with Company and Personal Sketches by Other Comrades, Also Complete Historical Rosters compiled by Virgil G. Way. Gibson City, IL: Published by the Regimental Association, 1902.

Evans, Thomas H. "The Cries of the Wounded were Piercing and Horrible." Civil War Times Illustrated 7 (July 1968): 28-38.

Fuller, Charles A. Personal Recollections of the War of 1861. Foreword by Gregory A. Coco. “After Gettysburg” by Herb S. Crumb. Hamilton, NY: Edmonston Publishing, Inc., 1990.

Grace, William. Army Surgeon's Manual, For the Use of Medical Officers, Cadets, Chaplains, and Hospital Stewards, Containing the Regulations of the Medical Department, all General Orders from the War Department, and Circulars from the Surgeon-General's Office. From January 1st, 1861, to April 1st, 1865. New York: Balliere Brothers, 1865. 
---. The Army Surgeon's Manual: For the Use of Medical Officers, Cadets, Chaplains, and Hospital Stewards. [Reprinted with a Bibliographical Introduction by Ira M. Rutkow, M .D., Dr. P. H.] San Francisco: Norman Publishing, 1992.

Gavin, William Gilfillan. Infantryman Pettit: The Civil War Letters of Corporal Frederick Pettit, Late of Company $C, 100^{\text {th }}$ Pennsylvania Veteran Volunteer Infantry Regiment "The Roundheads, ” 1862-1864. Shippensburg, PA: White Mane Publishing Company, Inc., 1990.

Hammond, William A., ed. Military Medical and Surgical Essays, prepared for the United States Sanitary Commission. Philadelphia: J. B. Lippincot \& Co., 1864.

Hammond, William A. A Treatise on the Diseases of the Nervous System. With One Hundred and Twelve Illustrations, Eighth Edition, with Corrections and Additions. New York: D. Appleton and Company, 1886.

---. A Treatise on Insanity in its Medical Relations. New York: Amo Press, 1973 [originally published 1883].

Haydon, Charles B. For Country, Cause \& Leader: The Civil War Journal of Charles B. Haydon. New York: Ticknor \& Fields, 1993.

Hosmer, James Kendall. Diary Entry for March 13, 1863. In The Color-Guard: Being a Corporal's Notes of Military Service in the Nineteenth Army Corps, 83. Boston: Walker Wise and Co., 1864. American Civil War: Letters and Diaries, accessed December 1, 2011, (Hosmer:D1425-8).

"Instructions from the Surgeon General Respecting Insane Soldiers," written November 7, 1864 by John P. Gray, E. H. Van Deusen, and Wm. P. Jones. Medical Officers of the New York State Lunatic Asylum, ed. The American Journal of Insanity Vol. XXI (Utica, NY: State Lunatic Asylum, 1864-5): 462-465.

Jones, William E. The Military History of the One Hundred and Sixty-first New York Volunteers, Infantry, from August 15 $5^{\text {th }}, 1862$ to October 17, 1865 (1865). Army Heritage and Education Center, Carlisle, PA.

La Rocca, Charles J. The Red Badge of Courage: An Historically Annotated Edition. Fleischmanns, NY: Purple Mountain Press, 1995.

Lyth, Alfred. "The Andersonville Diary of Private Alfred Lyth.” Niagra frontier 8, no. 1 (1961): 22.

Mattocks, Charles. "Unspoiled Heart”: The Journal of Charles Mattocks of the $17^{\text {th }}$ Maine. Edited by Philip N. Racine. Knoxville: The University of Tennessee Press, 1994. 
The Medical and Surgical History of the War of the Rebellion. Part III. Volume I. Medical History. Washington: Government Printing Office, 1888.

The Medical and Surgical History of the Civil War, Volume VI [Formerly Entitled The Medical and Surgical History of the War of the Rebellion]. Wilmington, NC: Broadfoot Publishing Company, 1991.

Meyer, Henry C. Experiences with the New York Cavalry: Under Bayard, Gregg, Kilpatrick, Custer, Raulston \& Newberry 1862-1864. Oakpost Ltd, 2010.

Mitchell, S. Weir. The Autobiography of a Quack and Other Stories. New York: The Century Co., 1905.

Mitchell, S. Weir, George R. Morehouse, and W. W. Keen, Jr. Reflex Paralysis: Circular No. 9 , Surgeon General's Office, March 10, 1864. A Reprint: With Introduction. Yale University School of Medicine, 1941.

Page, Charles D. History of the Fourteenth Regiment, Connecticut Vol. Infantry. Meriden, CT: The Horton Printing Co., 1906.

Patten, George, Lt. Col. Patten's Army Manual: Containing Instruction for Officers in the Preparation of Rolls, Returns and Accounts Required of Regimental and Company Commanders, and Pertaining to the Subsistence and Quartermasters' Departments. New York: J. W. Fortune, 1862.

Poriss, Gerry Harder, and Ralph G. Poriss. While My Country is in Danger: The Life and Letters of Lieutenant Colonel Richard S. Thompson, Twelfth New Jersey Volunteers. Hamilton, NY: Edmonston Publishing Inc., 1994.

Powers, Elvira J. “Diary of Elvira J. Powers, April 1864.” In Hospital Pencilings: Being a Diary while in Jefferson General Hospital, Jeffersonville, Indiana and Others at Nashville, Tennessee, as Matron and Visitor (Boston: E. L. Mitchell), 218. American Civil War: Letters and Diaries, accessed 28 January, 2014 (Powers: D975-1).

Record of Officers and Men of New Jersey in the Civil War, 1861-1865. Volume I. Compiled in the Office of the Adjutant General. William S. Stryker, Adjutant General. Trenton, NJ: John L. Murphy, Steam Book and Job Printer, 1876.

Record of service of Connecticut Men in the Army and Navy of the United States during the War of the Rebellion. Hartford, CT: Press of the Case, Lockwood \& Brainard, Co., 1889.

"Review: A Treatise on Insanity In Its Medical Relations by William A. Hammond." The British Medical Journal 1, 1204 (January 26, 1884): 170-171.

Rosenblatt, Emil, and Ruth Rosenblatt, ed. Hard Marching Every Day: The Civil War Letters of Private Wilbur Fisk. Lawrence, KS: University Press of Kansas, 1992. 
Rules and Regulations for the Government of the Grand Army of the Republic, as Revised and Adopted in National Convention, Cincinnati, Ohio, May 12 and 13, 1869. Washington, D.C.: Gibson Brothers, Printers, 1869.

Saxton, William. A Regiment Remembered: The 157th New York Volunteers: From the Diary of Capt. William Saxton. Cortland County Historical Society, 1996. Army Heritage and Education Center, Carlisle, PA.

Shepherd, William T. To Rescue My Native Land: The Civil War Letters of William T. Shepherd, First Illinois Light Artillery. Edited by Kurt H. Hackemer. Knoxville: The University of Tennessee Press, 2005.

Small, Abner Ralph. The Road to Richmond: The Civil War Memoirs of Major Abner R. Small of the Sixteenth Maine Volunteers. Together with the Diary which he kept when he was a Prisoner of War, with an introduction by Earl J. Hess. Edited by Harold Adams Small. New York: Fordham University Press, 2000.

Smedley, Charles. A Pennsylvania Quaker in Andersonville: The Diary of Charles Smedley. Foreword by James Durkin. Fulton Township, Lancaster County, PA: J. Michael Santarelli and James Durkin, 1995.

Stearns, Amos Edward. The Civil War Diary of Amos E. Stearns, A Prisoner at Andersonville. Rutherford, NJ: Fairleigh Dickinson University Press, 1981.

Throne, Mildred, ed. The Civil War Diary of Cyrus F. Boyd, Fifteenth Iowa Infantry, 1861-1863. Baton Rouge: Louisiana University Press, 1953.

United States Sanitary Commission. Sanitary Memoirs of the War of the Rebellion. 1867.

Watson, Ronald, ed. From Ashby to Andersonville: The Civil War Diary and Reminiscences of Private George A. Hitchcock, $21^{\text {st }}$ Massachusetts Infantry. Campbell, CA: Savas Publishing Company, 1997.

Welles, Gideon. "Diary of Gideon Welles, December, 1866." In Diary of Gideon Welles, Secretary of the Navy under Lincoln and Johnson, Vol. II. Edgar Thaddeus Welles, ed., 651-652. Boston, MA: Houghton, Mifflin \& Co., 1911. American Civil War: Letters and Diaries, accessed February 4, 2011, (Welles:D1982-32).

Westervelt, John H. Diary of a Yankee Engineer: The Civil War Story of John H. Westervelt, $1^{\text {st }}$ New York Volunteer Engineer Corps. Edited by Anita Palladino. New York: Fordham University Press, 1997.

Wheeler, William. "Letter from William Wheeler to Aunt E, November 25, 1862," Letters of William Wheeler of the Class of 1855, Y.C., 366. 1875. American Civil War: Letters and Diaries, accessed December 1, 2011, (Wheele:L1913-88). 
Wilkeson, Frank. Recollections of a Private Soldier in the Army of the Potomac. New York and London: G.P. Putnam's Sons, 1887.

Wilson, Byron B. “Letter XXXVI," Soldiers' Letters, from Camp, Battle-field and Prison, 99. New York: Bunce \& Huntington, 1865. American Civil War Letters and Diaries, accessed December 1, 2011, (Wilson:L1441-33).

Wilson, Oliver Morris. The Grand Army of the Republic Under its First Constitution and Ritual. Kansas City, MO: F. Hudson Publishing Co., 1905.

Young, Jesse Bowman. What A Boy Saw in the Army: A Story of Sight-Seeing and Adventure in the War for the Union. New York: Hunt \& Eaton, 1894.

\section{Unpublished Theses, Dissertations, and Papers:}

Bever, Megan Leigh. "War is a Terrible Enemy to Temperance: Drinking, Self-Control, and the Meaning of Loyalty in the Civil War." Ph.D. Dissertation, The University of Alabama, 2014.

Linares, Claudia. “The Civil War Pension Law.” Center for Population Economic Working Paper, University of Chicago, 2001.

Logothetis, Kathleen Anneliese. "A Question of Life or Death: Suicide and Survival in the Union Army.” M.A. Thesis, West Virginia University, 2012.

McMillen, Francis. "Ministering to a Mind Diseased: Landscape, Architecture and Moral Treatment at St. Elizabeth's Hospital, 1852-1905.” M.A. Thesis, University of Virginia, 2008.

Padilla, Jalynn Olsen. “Army of 'cripples': Northern Civil War Amputees, Disability, and Manhood in Victorian America." Ph.D. Dissertation, University of Delaware, 2007.

Pitts, John Albert. "The Association of Medical Superintendents of American Institutions for the Insane, 1844-1892: A Case Study of Specialism in American Medicine." Ph.D.

Dissertation, University of Pennsylvania, 1979.

Stagner, Annessa C. "Defining the Soldier's Wounds: U.S. Shell Shock in International Perspective." Ph.D. Dissertation, University of California, Irvine, 2014.

\section{Secondary Sources:}

Anderson, Judith. “'Haunted Minds': The Impact of Combat Exposure on the Mental and Physical Health of Civil War Veterans." In Years of Change and Suffering: Modern Perspectives on Civil War Medicine, edited by James M. Schmidt and Guy R. Hasegawa, 143-158. Roseville, MN: Edinborough Press, 2009. 
Arikha, Noga. Passions and Tempers: A History of the Humours. New York: HarperCollins Publishers, 2007.

Barr, Thomas F. "Cost and Compensations of the War," in Military Essays and Recollections: Papers read before the Commandery of the State of Illinois, Military Order of the Loyal Legion of the United States, Volume I. Chicago: A.C. McClurg and Company, 1891.

Bartlett, Peter, and David Wright, eds. Outside the Walls of the Asylum: The History of Care in the Community, 1750-2000. London: The Athlone Press, 1999.

Barton, Michael. Goodmen: The Character of Civil War Soldiers. University Park: Pennsylvania State University Press, 1981.

Barton, Michael, and Larry Logue, eds. The Civil War Soldier: A Historical Reader. New York: New York University Press, 2002.

Beaty, Nancy Lee. The Craft of Dying: A Study in the Literary Tradition of the Ars Moriendi in England. New Haven: Yale University Press, 1970.

Bell, Richard. We Shall Be No More: Suicide and Self-Government in the Newly United States. Cambridge, MA: Harvard University Press, 2012.

Berry, Stephen William. All That Makes a Man: Love and Ambition in the Civil War South. Oxford: Oxford University Press, 2003.

Berry, Stephen, ed. Weirding the War: Stories from the Civil War's Ragged Edges. Athens: The University of Georgia Press, 2011.

Binneveld, J. M. From Shell Shock to Combat Stress: A Comparative History of Military Psychiatry. Amsterdam: Amsterdam University Press, 1997.

Blanck, Peter. "Civil War Pensions and Disability." Ohio State Law Journal 62, no. 1 (Symposium: Facing the Challenges of the ADA: The First Ten Years and Beyond (2001): 117-118.

Bollet, Alfred Jay. Civil War Medicine: Challenges and Triumphs. Tucson, AZ: Galen Press, LTD, 2002.

Bourke, Joanna. An Intimate History of Killing: Face to Face Killing in $20^{\text {th }}$ Century Warfare. BasicBooks, 1999.

Bourne, Peter G. Men, Stress, and Vietnam. Boston: Little, Brown and Company, 1970.

Braceland, Francis J. The Institute of Living: The Hartford Retreat, 1822-1972. Hartford, CT: The Institute of Living, 1972. 
Brandt, Dennis W. Pathway to Hell: A Tragedy of the American Civil War. Lincoln: University of Nebraska Press, 2010.

Bryan, Craig J. "The Clinical Utility of a Brief Measure of Perceived Burdonsomeness and Thwarted Beloningness for the Detection of Suicidal Military Personnel." Journal of Clinical Psychology 67, no. 10 (2011): 981-992.

---. "Combat Experience and the Acquired Capability for Suicide." Journal of Clinical Psychology 66, no. 10 (2010): 1044-1056.

Cervetti, Nancy. S. Weir Mitchell, 1829-1914: Philadelphia's Literary Physician. University Park: Pennsylvania State University Press, 2012.

Cimbala, Paul A., and Randall M. Miller. Union Soldiers and the Northern Home Front: Wartime Experiences, Postwar Adjustments. New York: Fordham University Press, 2002.

Cimbala, Paul A. Veterans North and South: The Transition from Soldier to Civilian After the American Civil War. Santa Barbara, CA: Praeger, 2015.

Clarke, Frances M. War Stories: Suffering and Sacrifice in the Civil War North. Chicago: University of Chicago Press, 2011.

Coco, Gregory A. The Civil War Infantryman: In Camp, On the March, and in Battle. Gettysburg, PA: Thomas Publications, 1996.

---. A Strange and Blighted Land: Gettysburg: The Aftermath of a Battle. Gettysburg: Thomas Publications, 1995.

Comper, Frances M. M., ed. The Books of the Craft of Dying and Other Early English Tracts Concerning Death, Taken from Manuscripts and Printed in the British Museum and Bodleian Libraries, Now First Done into Modern Spelling and Edited by Frances M. M. Comper, with a Preface by the Rev. George Congreve, S. S. J. E. New York: Longmans, Green, and Co., 1917.

Costa, Dora L., and Matthew E. Kahn. Heroes \& Cowards: The Social Face of War. Princeton: Princeton University Press, 2008.

Cressy, David. Birth, Marriage, and Death: Ritual, Religion, and the Life-Cycle in Tudor and Stuart England. New York: Oxford University Press, 1997.

Curwen, John, comp. History of the Association of Medical Superintendents of American Institutions for the Insane, From 1844 to 1874, Inclusive: with a list of the different hospitals for the insane, and the names and dates of appointment and resignation of the medical superintendents. Compiled from the records of the Association by John Curwen, M. D., Secretary of the Association. 1875. 
Dain, Norman. Concepts of Insanity in the United States, 1789-1865. New Brunswick, NJ: Rutgers University Press, 1964.

Dean, Eric T., Jr. Shook Over Hell: Post-Traumatic Stress, Vietnam, and the Civil War. Cambridge, MA: Harvard University Press, 1997.

Dearing, Mary R. Veterans in Politics: The Story of the G.A.R. Baton Rouge: Louisiana University Press, 1952.

Deutsch, Albert. "Military Psychiatry: The Civil War, 1861-1865." In One Hundred Years of American Psychiatry, 1844-1944. Published by the American Psychiatric Association, 339-379. New York: Columbia University Press, 1944.

Dinter, Elmar. Hero or Coward: Pressures Facing the Soldier in Battle. Totowa, NJ: Frank Cass and Company Limited, 1985.

Dunkelman, Mark H. Brothers One and All: Esprit de Corps in a Civil War Regiment. Baton Rouge: Louisiana State University Press, 2004.

Fantina, Robert. Desertion and the American Soldier, 1776-2006. New York: Algora Publishing, 2006.

Faust, Drew Gilpin. "Christian Soldiers: The Meanings of Revivalism in the Confederate Army." The Journal of Southern History 53, no. 1 (Feb. 1987): 66-90.

---. This Republic of Suffering: Death and the American Civil War. New York: Alfred A. Knopf, 2008.

Foos, Paul. A Short, Offhand, Killing Affair: Soldiers and Social Conflict During the MexicanAmerican War. Chapel Hill: University of North Carolina Press, 2002.

Foote, Lorien. The Gentlemen and the Roughs: Manhood, Honor and Violence in the Union Army. New York: New York University Press, 2010.

Frank, Joseph Allen, and George A. Reaves. "Seeing the Elephant": Raw Recruits at the Battle of Shiloh. Urbana, IL: University of Illinois Press, 1989.

Gabriel, Richard A. No More Heroes: Madness \& Psychiatry in War. New York: Hill and Wang, 1987.

Gannon, Barbara A. The Won Cause: Black and White Comradeship in the Grand Army of the Republic. Chapel Hill: University of North Carolina Press, 2011.

Glasson, William H. Federal Military Pensions in the United States. New York: Oxford University Press, 1918. 
Glatthaar, Joseph T. "The Common Soldier of the Civil War." In New Perspectives on the Civil War: Myths and Realities of the National Conflict. Edited by John Y. Simon and Michael E. Stevens. Madison, WI: Madison House Publishers, Inc., 1998.

Gordon, Lesley J. A Broken Regiment: The $16^{\text {th }}$ Connecticut's Civil War. Baton Rouge: Louisiana State University Press, 2014.

---. “I Never Was a Coward': Questions of Bravery in a Civil War Regiment." In More Than a Contest Between Armies: Essays on the Civil War Era, edited by James Marten and A. Kristen Foster, 145-167. Kent, OH: The Kent State University Press, 2008.

Grant, Susan-Mary. "Reimagined Communities: Union Veterans and the Reconstruction of American Nationalism." Nations and Nationalism 14, 3 (2008): 498-519.

Greenberg, Amy S. Manifest Manhood and the Antebellum American Empire. New York: Cambridge University Press, 2005.

Grob, Gerald N. The Mad Among Us: A History of the Care of America's Mentally Ill. New York: The Free Press, 1994.

---. Mental Institutions in America: Social Policy to 1875. New York: The Free Press, 1973.

Grossman, Dave, Lt. Col. On Killing: The Psychological Cost of Learning to Kill in War and Society. New York: Back Bay Books, 2009.

Harris, M. Keith. Across the Bloody Chasm: The Culture of Commemoration Among Civil War Veterans. Baton Rouge: Louisiana State University Press, 2014.

Hess, Earl J. The Union Soldier in Battle: Enduring the Ordeal of Combat. Lawrence, KS: The University Press of Kansas, 1997.

Holmes, Richard. Acts of War: The Behavior of Men in Battle. New York: The Free Press, 1985.

Howe, Daniel Walker. What God Hath Wrought: The Transformation of America, 1815-1848. New York: Oxford University Press, 2007.

Janney, Caroline E. Remembering the Civil War: Reunion and the Limits of Reconciliation. Chapel Hill: The University of North Carolina Press, 2013.

Jimerson, Randall C. The Private Civil War: Popular Thought During the Sectional Conflict. Baton Rouge: Louisiana State University Press, 1988.

Joiner, Thomas. Why People Die By Suicide. Cambridge: Harvard University Press, 2005.

Jones, Edgar. Shell Shock to PTSD: Military Psychiatry from 1900 to the Gulf War. Hove: Psychology Press, 2005. 
Jordan, Brian Matthew. Marching Home: Union Veterans and Their Unending Civil War. New York: Liveright Publishing Corporation, 2015.

Keegan, John. The Face of Battle. New York: Penguin Books, 1976.

Kelly, Patrick J. Creating a National Home: Building the Veterans' Welfare State, 1860-1900. Cambridge, MA: Harvard University Press, 1997.

Krippner, Stanley. Post-Traumatic Stress Disorder. Santa Barbara, CA: Greenwood, 2012.

Lahad, Mooli, and Miki Doron. Protocol for Treatment of Post Traumatic Stress Disorder. SEE FAR CBT Model: Beyond Cognitive Behavior Therapy. Part of the NATO Science for Peace and Security Project ASI 983481. Amsterdam: IOS Press, 2010.

Lande, R. Gregory. Madness, Malingering, and Malfeasance: The Transformation of Psychiatry and the Law in the Civil War Era. Washington, D.C.: Brassey's, Inc., 2003.

Lentz, Perry. Private Fleming at Chancellorsville: The Red Badge of Courage and the Civil War. Columbia: University of Missouri Press, 2006.

Linderman, Gerald F. Embattled Courage: The Experience of Combat in the American Civil War. New York: The Free Press, 1987.

Livingston, Steven G. Student's Guide to Landmark Congressional Laws on Social Security and Welfare. Wesport, CT: Greenwood Press, 2002.

Louge, Larry M., and Michael Barton, eds. The Civil War Veteran: A Historical Reader. New York: New York University Press, 2007.

Logue, Larry M. Race, Ethnicity, and Disability: Veterans and Benefits in Post-Civil War America. New York: Cambridge University Press, 2010.

Long, Lisa. Rehabilitating Bodies: Health, History, and the American Civil War. Philadelphia: University of Pennsylvania Press, 2004.

Lonn, Ella. Desertion During the Civil War. New York: The Century Co., 1928.

Marshall, S. L. A. Men Against Fire: The Problem of Battle Command in Future War. New York: The Infantry Journal and William Morrow \& Company, 1947.

Marten, James. Civil War America: Voices from the Homefront. New York: Fordham University Press, 2007.

---. Sing Not War: The Lives of Union \& Confederate Veterans in Gilded Age America. Chapel Hill: The University of North Carolina Press, 2011. 
Marvel, William. Andersonville: The Last Depot. Chapel Hill: The University of North Carolina Press, 1994.

McConnell, Stuart. Glorious Contentment: The Grand Army of the Republic, 1865-1900. Chapel Hill: The University of North Carolina Press, 1992.

McClurken, Jeffrey W. Take Care of the Living: Reconstructing Confederate Families in Virginia. Charlottesville: University of Virginia Press, 2009.

McPherson, James M. For Cause \& Comrades: Why Men Fought in the Civil War. New York: Oxford University Press, 1997.

Meier, Kathryn Shively. Nature's Civil War: Common Soldiers and the Environment in 1862 Virginia. Chapel Hill: The University of North Carolina Press, 2013.

Micale, S., and Paul Lerner. Traumatic Pasts: History, Psychiatry, and Trauma in the Modern Age, 1870-1930. Cambridge: Cambridge University Press, 2001.

Miller, Brian Craig. Empty Sleeves: Amputation in the Civil War South. Athens: The University of George Press, 2015.

Miller, Randall M., Harry S. Stout, and Charles Reagan Wilson, eds. Religion and the American Civil War. Oxford: Oxford University Press, 1998.

Mitchell, Reid. Civil War Soldiers: Their Expectations and Their Experiences. New York: Viking Penguin, Inc., 1988.

---. The Vacant Chair: The Northern Soldier Leaves Home. New York: Oxford University Press, 1993.

Murray, R.L. New Yorkers in the Civil War, A Historic Journal, Volume 3. Wolcott, NY: Benedum Books, 2004.

Nelson, Megan Kate. Ruin Nation: Destruction and the American Civil War. Athens, GA: The University of Georgia Press, 2012.

Noll, Mark A. America's God: From Jonathan Edwards to Abraham Lincoln. New York: Oxford University Press, 2002.

Paulson, Daryl S. Haunted by Combat: Understanding PTSD in War Veterans Including Women, Reservists, and Those Coming Back from Iraq. Westport, CT: Praeger Security International, 2007.

Phisterer, Frederick. Statistical Record of the Armies of the United States. New York: Charles Scribner's Sons, 1883. 
Pickenpaugh, Roger. Captives in Blue: The Civil War Prisons of the Confederacy. Tuscaloosa: The University of Alabama Press, 2013.

Rable, George C. God's Almost Chosen People: A Religious History of the American Civil War. Chapel Hill: The University of North Carolina Press, 2010.

Ramold, Steven J. Baring the Iron Hand: Discipline in the Union Army. DeKalb: Northern Illinois University Press, 2010.

Reid, Fiona. Broken Men: Shell Shock, Treatment, and Recovery in Britain, 1914-1930. London: Continuum, 2010.

Reiss, Benjamin. Theaters of Madness: Insane Asylums and Nineteenth-Century American Culture. Chicago: The University of Chicago Press, 2008.

Robertson, James I., Jr. Soldiers Blue and Gray. Columbia: University of South Carolina Press, 1998.

Rolfs, David. No Peace for the Wicked: Northern Protestant Soldiers and the American Civil War. Knoxville: The University of Tennessee Press, 2009.

Rosen, George. Madness in Society: Chapters in the Historical Sociology of Mental Illness. Chicago: The University of Chicago Press, 1968.

Rothman, David J. The Discovery of the Asylum: Social Order and Disorder in the New Republic. Boston: Little, Brown and Company, 1971.

Rutkow, Ira M. Bleeding Blue and Gray: Civil War Surgery and the Evolution of American Medicine. New York: Random House, 2005.

Sanders, Charles W., Jr. While in the Hands of the Enemy: Military Prisons of the Civil War. Baton Rouge: Louisiana State University Press, 2005.

Saum, Lewis O. "Death in the Popular Mind of Pre-Civil War America." American Quarterly 26, no. 5 (December 1974): 477-495.

---. The Popular Mood of Pre-Civil War America. Westport, CT: Greenwood Press, 1980.

Schantz, Mark S. Awaiting the Heavenly Country: The Civil War and America's Culture of Death. Ithaca: Cornell University Press, 2008.

Sheehan-Dean, Aaron, ed. The View from the Ground: Experiences of Civil War Soldiers. Lexington, KY: The University Press of Kentucky, 2007. 
Silkenat, David. Moments of Despair: Suicide, Divorce \& Debt in Civil War Era North Carolina. Chapel Hill: The University of North Carolina Press, 2011.

Shalit, Ben. The Psychology of Conflict and Combat. New York: Praeger Press, 1988.

Skocpol, Theda. Protecting Soldiers and Mothers: The Political Origins of Social Policy in the United States. Cambridge, MA: The Belknap Press of Harvard University Press, 1992.

Sommerville, Diane Miller. “'A Burden Too Heavy to Bear': War Trauma, Suicide and Confederate Soldiers." Civil War History 59, no. 4 (December 2013): 453-491.

---. "CCumberer of the Earth': Suicide and Faith in the Post-Civil War South." In Death in the American South, edited by Craig Thompson Friend and Lorri Glover, 153-180. New York: Cambridge University Press, 2014.

Stout, Harry. Upon the Altar of the Nation: A Moral History of the American Civil War. New York: Viking, 2006.

Tomes, Nancy. The Art of Asylum Keeping: Thomas Story Kirkbride and the Origins of American Psychiatry. Philadelphia: University of Pennsylvania Press, 1994.

Watson, Peter. War on the Mind: The Military Uses and Abuses of Psychology. New York: Basic Books, Inc., Publishers, 1978.

Weitz, Mark A. More Damning than Slaughter: Desertion in the Confederate Army. Lincoln, NE: University of Nebraska Press, 2005.

Wells, Cheryl A. Civil War Time: Temporality \& Identity in America, 1861-1865. Athens, GA: The University of Georgia Press, 2005.

Wiederhold, Brenda K., ed. Coping with Blast-Related Traumatic Brain Injury in Returning Troops. Wounds of War III-Coping with Blast-Related Traumatic Brain Injury in Returning Troops. NATO Sponsored Science for Peace and Security Programme Initiative, February 2011. Amsterdam: IOS Press, 2011.

---. Coping with Posttraumatic Stress Disorder in Returning Troops. Wounds of War IIPosttraumatic Stress Disorder in Peacekeeping and Combat Troops. NATO Sponsored Science for Peace and Security Programme Initiative, October 2009.

---. Lowering Suicide Risk in Returning Troops. Wounds of War-Lowering Suicide Risk in Returning Troops. NATO Sponsored Science for Peace and Security Programme Initiative, October 2007. Amsterdam: IOS Press, 2008.

Wiley, Bell I. The Common Soldier of the Civil War. New York: Charles Scribner's Sons, 1975. 
---. The Life of Billy Yank: The Common Soldier of the Union. The Bobbs-Merrill Company, Inc., 1951, 1952.

Wilson, John P., and Beverly Raphael. International Handbook of Traumatic Stress Syndromes. New York: Plenum Press, 1993.

Woodworth, Steven E. While God is Marching On: The Religious World of Civil War Soldiers. Lawrence, KS: University Press of Kansas, 2001.

Wooley, Charles F. The Irritable Heart of Soldiers and the Origins of Anglo-American Cardiology: The US Civil War (1861) to World War I (1918). Burlington, VT: Ashgate Publishing Company, 2002.

---. "Jacob Mendez DaCosta: Medical Teacher, Clinician, and Clinical Investigator." The American Journal of Cardiology 50 (November 1982): 1145-1148.

Yanni, Carla. The Architecture of Madness: Insane Asylums in the United States. Minneapolis: University of Minnesota Press, 2007. 